\title{
Interaction mechanisms of platelets and coagulation : focus on P2Y12 receptor and factor XII
}

Citation for published version (APA):

van der Meijden, P. E. J. (2008). Interaction mechanisms of platelets and coagulation : focus on P2Y12 receptor and factor XII. [Doctoral Thesis, Maastricht University]. Datawyse / Universitaire Pers Maastricht. https://doi.org/10.26481/dis.20081203pm

Document status and date:

Published: 01/01/2008

DOI:

10.26481/dis.20081203pm

Document Version:

Publisher's PDF, also known as Version of record

\section{Please check the document version of this publication:}

- A submitted manuscript is the version of the article upon submission and before peer-review. There can be important differences between the submitted version and the official published version of record.

People interested in the research are advised to contact the author for the final version of the publication, or visit the DOI to the publisher's website.

- The final author version and the galley proof are versions of the publication after peer review.

- The final published version features the final layout of the paper including the volume, issue and page numbers.

Link to publication

\footnotetext{
General rights rights.

- You may freely distribute the URL identifying the publication in the public portal. please follow below link for the End User Agreement:

www.umlib.nl/taverne-license

Take down policy

If you believe that this document breaches copyright please contact us at:

repository@maastrichtuniversity.nl

providing details and we will investigate your claim.
}

Copyright and moral rights for the publications made accessible in the public portal are retained by the authors and/or other copyright owners and it is a condition of accessing publications that users recognise and abide by the legal requirements associated with these

- Users may download and print one copy of any publication from the public portal for the purpose of private study or research.

- You may not further distribute the material or use it for any profit-making activity or commercial gain

If the publication is distributed under the terms of Article $25 \mathrm{fa}$ of the Dutch Copyright Act, indicated by the "Taverne" license above, 


\section{Interaction mechanisms of platelets and coagulation}

focus on $P 2 Y_{12}$ receptor and factor $X I I$ 
Interaction mechanisms of platelets and coagulation

focus on $P 2 Y_{12}$ receptor and factor $X I I$

Thesis Universiteit Maastricht

ISBN 978-90-5278-777-0

(c) P.E.J. van der Meijden, Maastricht 2008

Printed by Datawyse | Universitaire Pers Maastricht 


\title{
Interaction mechanisms of platelets and coagulation
}

focus on $P 2 Y_{12}$ receptor and factor $X I I$

\author{
PROEFSCHRIFT
}

ter verkrijging van de graad van doctor

aan de Universiteit Maastricht,

op gezag van de Rector Magnificus,

Prof. mr. G.P.M.F. Mols,

volgens het besluit van het College van Decanen,

in het openbaar te verdedigen op woensdag

3 december 2008 om 14.00 uur

door

Paola Elisabeth Johannes van der Meijden

Geboren op 15 februari 1981 te Geleen

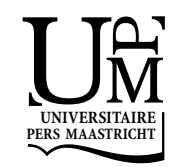




\section{Promotor}

Prof. Dr. J. Rosing

\section{Copromotor}

Dr. J.W.M. Heemskerk

\section{Beoordelingscommissie}

Prof. Dr. A. Bast (voorzitter)

Dr. L. Hofstra

Prof. Dr. M.F. Hoylaerts (Katholieke Universiteit Leuven, België)

Prof. Dr. Ph.G. de Groot (Universitair Medisch Centrum, Utrecht)

Prof. Dr. H.A.J. Struijker Boudier

Financial support by the Netherlands Heart Foundation and by Thrombinoscope BV for the publication of this thesis is gratefully acknowledged. 
Logica brengt je van A naar B. Verbeelding brengt je overal. (A. Einstein) 



\section{Contents}

$\begin{array}{lll}\text { Chapter } 1 & \text { General introduction } & 9\end{array}$

Chapter $2 \quad$ Classification of venous thromboembolism (VTE). 21

Platelets in venous thrombosis

Chapter $3 \quad$ Platelet $\mathrm{P} 2 \mathrm{Y}_{12}$ receptors enhance signaling towards

procoagulant activity and thrombin generation. A study

with healthy subjects and patients at thrombotic risk

Chapter $4 \quad$ Dual $\mathrm{P}_{2} \mathrm{Y}_{12}$ receptor signaling in thrombin-stimulated platelets. Involvement of phosphoinositide 3-kinase $\beta$ but not $\gamma$ isoform in $\mathrm{Ca}^{2+}$ mobilization and procoagulant activity

Chapter $5 \quad$ Role of integrin $\alpha$ llb $\beta 3$ outside-in signaling in the development of platelet procoagulant activity and thrombin generation

Chapter 6 Dual role of collagen in factor XII-dependent thrombus and clot formation

Chapter $7 \quad$ General discussion

Summary

Samenvatting

Curriculum vitae

Publications

Dankwoord 

General introduction 


\section{Hemostasis and thrombosis}

Under normal conditions the blood is maintained in a fluid state, but after vascular damage the hemostatic system functions to arrest hemorrhage by inducing the formation of a clot. When the hemostatic balance is disturbed in intact vessels, thrombosis may occur with vascular occlusion as a result. In the arterial system, thrombosis is characterized predominantly by platelets (so-called white thrombus), while thrombi in the venous system are rich in fibrin and erythrocytes (so-called red thrombi). ${ }^{1}$

The main trigger for the formation of a thrombus after arterial injury is endothelial damage, as a consequence of which flowing blood comes into contact with extracellular matrix components, such as collagen, laminin, fibronectin and von Willebrand factor $(\mathrm{VWF})^{2,3}$ Platelets play a fundamental role in the ensuing (patho)physiological processes. In the classical concept of thrombus formation, platelets adhere to the subendothelial structures, become activated and accumulate into a growing platelet aggregate (platelet plug). Subsequent activation of the coagulation cascade via exposure of tissue factor is considered to lead to the formation of thrombin and fibrin, which stabilizes the thrombus and forms a clot. ${ }^{4}$ However, new intravital technologies in examining thrombus formation in vivo have demonstrated that platelet aggregate formation and fibrin clot formation locally overlap and occur almost simultaneously. ${ }^{5}$ Another classical concept is that platelets activated by thrombin and collagen stimulate the coagulation cascade by providing a membrane surface for the assembly of coagulation factors. ${ }^{6}$ As a consequence, platelet activation and coagulation are highly interdependent processes, occurring simultaneously and stimulating each other. ${ }^{7}$ In spite of major achievements in this area during the last decades, there is still incomplete understanding of the precise interaction mechanisms of platelet activation and coagulation.

Arterial and venous thrombosis are usually treated with anti-platelet and anticoagulation medication, respectively. Only few studies have been performed with combinations of this medication and not all had a positive outcome. Hence, better understanding of the ways how platelets influence the coagulation system and vice versa is required for more effective treatment of cardiovascular diseases.

To provide background information, the remaining part of this chapter will focus on the platelet agonists and signaling pathways that are relevant for the interactions of platelets and coagulation. In addition, a brief outline will be given of the coagulation cascade. Extensive overviews of the roles of platelets in thrombus formation and coagulation, as well as the classical signaling mechanisms involved, are given elsewhere. $^{3,8}$

\section{Platelet activation by soluble agonists}

The serine protease thrombin plays a central role in coagulation by converting fibrinogen to fibrin and, in addition, it is among the most potent activators of platelets. ${ }^{9}$ Thrombin provokes a shape change of platelets, secretion of granules and activation of integrin $\alpha \mathrm{llb} \beta 3$ which mediates platelet aggregation. Thrombin exerts these effects by interacting 
with $\mathrm{G}$ protein-coupled protease-activated receptors (PARs). ${ }^{10}$ Human platelets express the isoforms PAR1 and PAR4 ${ }^{11,12}$, while mouse platelets express PAR3 and PAR4. ${ }^{13}$ Both PAR1 and PAR4 contain their own receptor-activating ligand. Thrombin cleaves the $\mathrm{N}$-terminal exodomain at an arginine residue, which then unmasks a new $\mathrm{N}$-terminus serving as tethered ligand for the receptors. ${ }^{14}$ It has been established that PAR1 mediates human platelet activation at low thrombin concentrations, whereas PAR4 activation requires high concentrations of thrombin. Activation of PARs in mouse platelets occurs slightly different than in human platelets as PAR3 is not cleaved by thrombin, but functions as a cofactor for PAR4 to promote its cleavage and activation at low thrombin concentrations. ${ }^{10}$

Once cleaved by thrombin, both PAR1 and PAR4 activate heterotrimeric G proteins of the $\mathrm{G} 13$ and $\mathrm{Gq}$ families (Figure $1 \mathrm{~A}$ ). Activation of $\mathrm{G} 13$ stimulates the Rho/Rhokinase-mediated signaling pathway, which mediates reorganization of the actin cytoskeleton and results in platelet shape change. $\mathrm{Gq}$ activation stimulates the $\beta$ isoform of phospholipase $C$, resulting in the formation of diacylglycerol (DAG) and inositol 1,4,5triphosphate $\left(\mathrm{IP}_{3}\right)$ from phosphatidylinositol-(4,5)-biphosphate $\left(\mathrm{PIP}_{2}\right)$. DAG activates protein kinase $\mathrm{C}$, a key signaling protein in platelets, as well as the Rap $1 \mathrm{~b}$ exchange factor, CaIDAG-GEF. ${ }^{15}$ The other second messenger $\mathrm{IP}_{3}$ releases $\mathrm{Ca}^{2+}$ from intracellular stores, primarily the endoplasmatic reticulum, by interacting with $\mathrm{IP}_{3}$ receptor channels. Once the intracellular $\mathrm{Ca}^{2+}$ stores are depleted, $\mathrm{Ca}^{2+}$ entry from the extracellular medium is activated. ${ }^{16-18}$ The identity of the $\mathrm{Ca}^{2+}$ entry channels has for long remained unclear. Recently, a role for STIM and Orai proteins have been identified in $\mathrm{Ca}^{2+}$ entry. ${ }^{19,20}$ Early

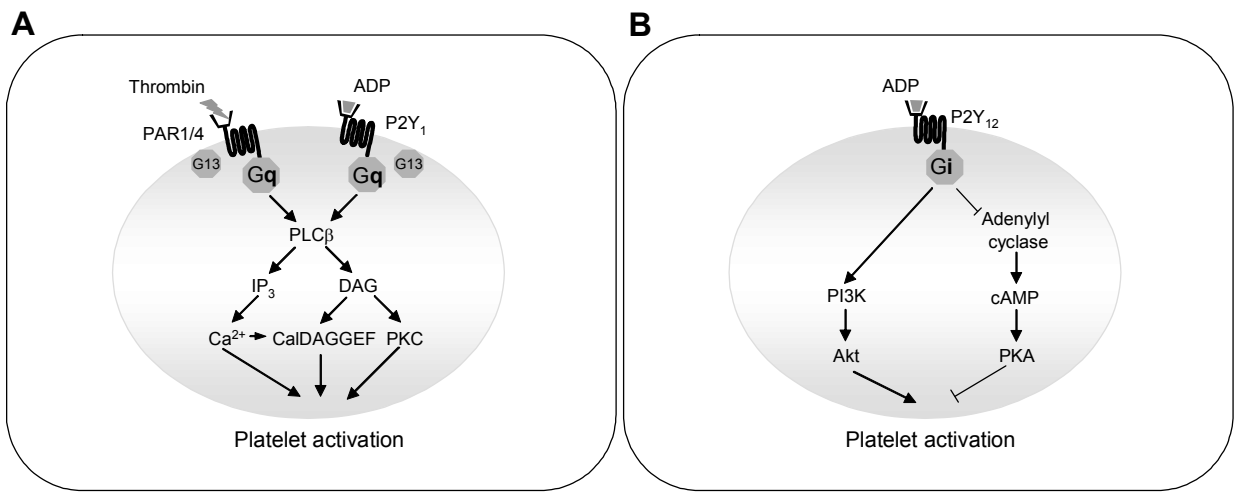

Figure 1. Thrombin- and ADP-induced signaling pathways in platelets. (A) The thrombin receptors PAR1 and PAR4 and the ADP receptor $P 2 Y_{1}$ couple to $G q$ and activate phospholipase $C \beta$ $(\mathrm{PLC} \beta)$, which leads to the formation of inositol 1,4,5-triphosphate $\left(\mathrm{IP}_{3}\right)$ and diacylglycerol (DAG). $\mathrm{IP}_{3}$ releases $\mathrm{Ca}^{2+}$ from the intracellular stores and DAG activates protein kinase $C(P K C)$ and the guanine nucleotide exchange factor, CalDAGGEF. (B) The other ADP receptor P2Y ${ }_{12}$ couples to $\mathrm{Gi}$, which on the one hand activates phosphoinositide 3-kinase (PI3-K) and Akt and on the other hand inhibits adenylyl cyclase, thereby decreasing the formation of cAMP and inhibiting protein kinase A (PKA). Activation of these Gq-coupled pathways results in platelet activation and aggregation via integrin $\alpha$ llb $\beta 3$. 
data suggested that PARs might also couple to the $\mathrm{Gi}$ protein, but current evidence shows that $\mathrm{Gi}$ signaling in response to thrombin occurs indirectly via ADP, which is released upon platelet stimulation. ${ }^{10,21}$ Thromboxane $A_{2}$, autocrine produced by phospholipase A2 and cyclooxygenase activation, signals via Gq-coupled receptors in a similar way as thrombin.

Another positive feedback mediator of platelet activation is ADP, which is released from the dense granules. Two $G$ protein-coupled receptors for ADP are present on platelets, namely $\mathrm{P}_{2} \mathrm{Y}_{1}$ and $\mathrm{P} 2 \mathrm{Y}_{12}$. The $\mathrm{P} 2 \mathrm{Y}_{1}$ receptor couples to $\mathrm{Gq}$ and signals in the same way as PAR1/4 (Figure 1A). On the contrary, the P2Y 12 receptor couples to $G i$ and inhibits adenylyl cyclase, the enzyme that produces CAMP and activates protein kinase $A$ $(\mathrm{PKA}){ }^{21,22}$ In addition, $\mathrm{Gi}$ signaling also results in stimulation of phosphoinositide 3kinase (PI3-K), which forms phosphatidylinositol 3,4,5-trisphosphate $\left(\mathrm{PIP}_{3}\right)$ to activate downstream signaling targets, including protein kinase B/Akt (Figure 1B). ${ }^{22,23}$ Using these two signaling pathways the $P 2 Y_{12}$ receptor functions to complete platelet aggregation and potentiate platelet secretion. ${ }^{24}$ Especially the $\beta$ - and $\gamma$-isoforms of PI3-K mediate ADP-induced aggregation. ${ }^{25}$ It is still unclear whether PI3-K isoforms also influence other platelet functions than aggregation. In addition to ADP, platelets secrete ATP which activates the ligand-gated cation channel $P 2 X_{1}$ and thereby induces fast $\mathrm{Ca}^{2+}$ entry. ${ }^{22}$ It has been shown that $\mathrm{P} 2 \mathrm{X}_{1}$ participates in shape change and aggregation in response to collagen. ${ }^{26}$

\section{Platelet activation by adhesive agonists}

Collagens are richly present in the vessel wall. They become exposed to the blood stream upon vascular injury, and support platelet adhesion and activation. The most abundant fibrillar collagens in the vessel wall, types I and III, are also adhesive for platelets. $^{27}$ Two major collagen receptors are implicated in platelet-collagen interaction, i.e. integrin $\alpha 2 \beta 1$ and glycoprotein $\mathrm{VI}$ (GPVI), with the latter being the dominant receptor in inducing signaling. ${ }^{28}$ The signaling pathways are extensively described elsewhere. ${ }^{29}$ Briefly, GPVI associates with the Fc receptor (FcR) $\gamma$-chain that contains an immunoreceptor tyrosine-based activation motif (ITAM). Collagen causes cross-linking of GPVI, which induces tyrosine phosphorylation of the FcR $\gamma$-chain ITAM by the Src kinases, Fyn and Lyn (Figure 2A). This leads to recruitment of the $\mathrm{SH} 2$ domaincontaining Syk, which by downstream signaling results in the formation of a large activation complex. ${ }^{27}$ This complex includes adapter proteins that act as docking sites for effector enzymes, such as phospholipase $\mathrm{C} \gamma 2$ (PLC $\gamma 2$ ) and PI3-K. The adapter proteins LAT, SLP-76 and Gads have a partly overlapping role herein. Similarly to PLC $\beta$, PLC $\gamma 2$ releases $\mathrm{Ca}^{2+}$ from the internal stores via $\mathrm{PIP}_{2}$ cleavage and $\mathrm{IP}_{3}$ formation. Evidence has been presented for a LAT-independent way of PLC $\gamma 2$ activation, but the mechanism is still unclear. In addition, it is proposed that PLC $\gamma 1$ can act as a backup effector if PLC $\gamma 2$ is absent. ${ }^{29,30}$

Another important adhesive receptor is integrin $\alpha \mathrm{llb} \beta 3$ which is required for platelet aggregation and spreading on extracellular matrices. Both the $\alpha$ llb and the 
A

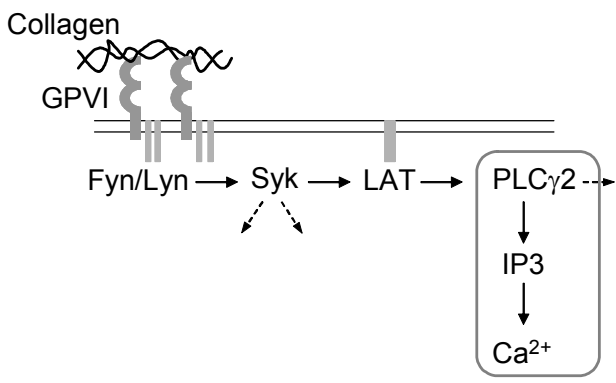

B

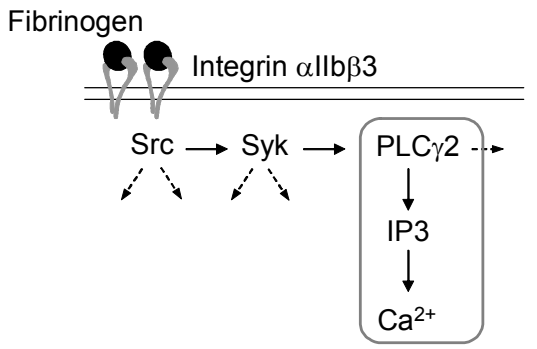

Figure 2. Signaling pathways to $\mathrm{Ca}^{2+}$ release in platelets adhered to collagen or fibrinogen. (A) Collagen clusters glycoprotein VI (GPVI), which then associates with the Fc receptor (FcR) $\gamma$-chain. Phosphorylation events by the Src kinases Fyn and Lyn leads to recruitment of Syk and phosphorylation of the transmembrane adapter protein LAT. LAT serves as a docking site for phospholipase $\mathrm{C} \gamma 2$ (PLC $\gamma 2)$, which causes $\mathrm{IP}_{3}$ formation and release of $\mathrm{Ca}^{2+}$. (B) Fibrinogen binds to and clusters integrin $\alpha$ llb $\beta 3$. Integrin clustering results in activation of $\mathrm{Src}$, which is bound to the $\beta 3$ tail, and subsequent activation of Syk. PLC $\gamma 2$ is activated, likely via Syk, and $\mathrm{Ca}^{2+}$ is released from the internal stores.

$\beta 3$-chains consist of a large extracellular moiety and a short cytoplasmic tail. Integrin $\alpha$ llb $\beta 3$ is capable of bidirectional signaling, as specific proteins can bind to the intracellular or extracellular moieties and cause functional changes. ${ }^{31,32}$ Activation of the thrombin, ADP or collagen receptors increases the activation state of integrin allb $\beta 3$, via the signaling pathways mentioned above. This 'inside-out' signaling causes a reversible conformational transition in $\alpha$ llb $\beta 3$ to allow binding of the ligands, fibrinogen and von Willebrand factor. ${ }^{33} \mathrm{~A}$ critical step herein appears to be interaction of the actin-associated protein talin with the $\beta 3$ chain. $^{34}$ On the other hand, ligand binding to $\alpha \operatorname{llb} \beta 3$ and subsequent integrin clustering provokes 'outside-in' signals that in turn promote actin cytoskeletal reorganization and granule secretion. Outside-in signaling involves activation of Src and Syk kinases, which in turn stimulate the effector proteins PLC $\gamma 2$ and $\mathrm{PI} 3-\mathrm{K}$ (Figure 2B). Src kinase is constitutively associated with the $\beta 3$ cytoplasmic tail and becomes activated when fibrinogen clusters $\alpha$ llb $\beta 3$. Syk is then recruited to the $\beta 3$ tail and is activated by Src. It is proposed that Syk plays a role in the phosphorylation of PLC $\gamma 2{ }^{30,31}$ Outside-in signaling pathways independent of Syk have also been described and involve tyrosine phosphorylation of the $\beta 3$-integrin tail and the proteins Shc, Dok2 and myosin. ${ }^{30,35}$ Functional platelet responses of outside-in signaling are only limitedly investigated, but include spreading on a fibrinogen surface and clot retraction. ${ }^{36}$ Although many proteins interact with $\alpha \mathrm{llb} \beta 3$, their functions remain to be explored. ${ }^{31}$

\section{Coagulation and the platelet procoagulant response}

Blood coagulation occurs by a series of enzymatic reactions in which zymogens of serine proteases are converted into active coagulation factors (enzymes), which eventually lead to the formation of thrombin and fibrin. The presence of many positive and negative 
feedback loops makes the coagulation system quite complex. ${ }^{37}$ For the purpose of this thesis, only a simplified figure is given in Figure 3. One way to initiate the coagulation process is by exposure of tissue factor (extrinsic pathway). ${ }^{38}$ Tissue factor is expressed on vascular cells or present in the blood in an encrypted form. ${ }^{39}$ Once exposed and active, it forms a complex with factor VIla and activates factors X and IX to Xa and IXa, respectively. With factor VIIla as a cofactor, factor IXa can activate factor X, whereas factor $\mathrm{Va}$ functions as a cofactor for factor $\mathrm{Xa}$ in the conversion of prothrombin into thrombin. $^{2,40}$ Thrombin amplifies its own formation by activating factors $\mathrm{V}, \mathrm{VIII}$ and $\mathrm{XI}$, although the physiological relevance of this way of factor $\mathrm{XI}$ activation is recently debated. ${ }^{41}$ Fibrin formed by thrombin stabilizes the thrombus.

The alternative way to trigger coagulation (contact activation or intrinsic pathway) involves factor XII. This is supposed to start when factor XII comes into contact with negatively charged surfaces, e.g. subendothelial matrix proteoglycans, glycosaminoglycans and collagens (Figure 3). ${ }^{42}$ However, which is the main physiological activator of factor XII is still debated. ${ }^{43}$ Artificial negatively charged materials like kaolin and glass are used as non-physiological activators of this pathway in clotting assays. At these surfaces, factor XII is converted into its activated form with the

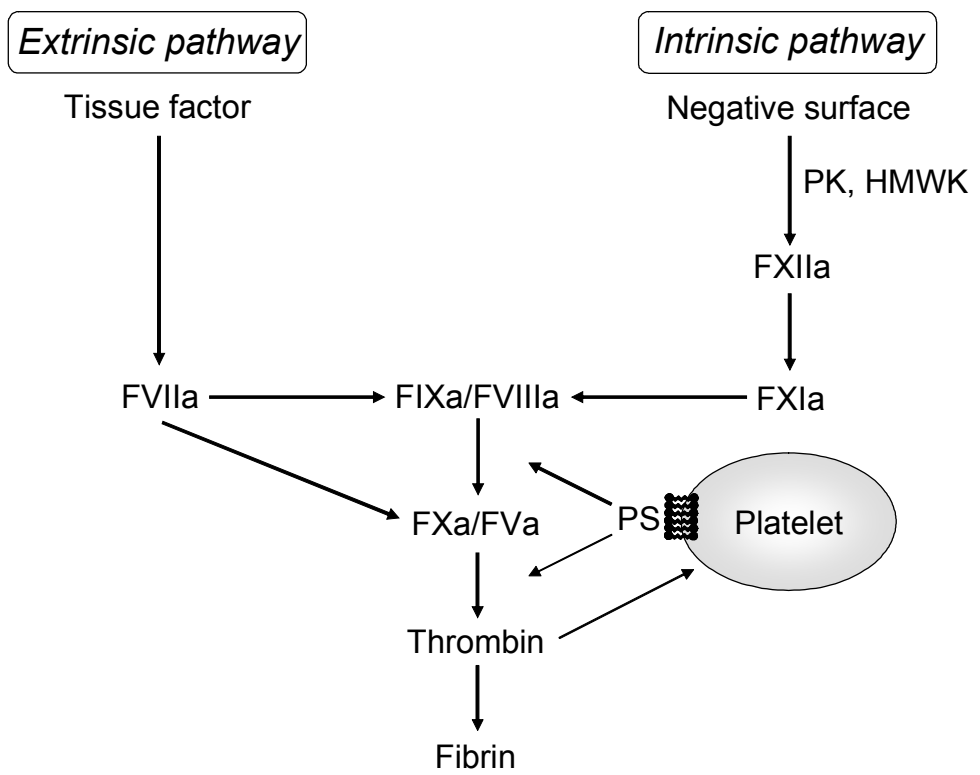

Figure 3. Simplified overview of extrinsic and intrinsic pathways of thrombin generation. The extrinsic pathway is initiated by complex formation of tissue factor with factor $(F)$ Vlla. Subsequent activation of FIX and FX results in the conversion of prothrombin into thrombin. The intrinsic pathway is initiated by contact of FXII with negatively charged surfaces, involving prekallikrein (PK) and high molecular weight kininogen (HMWK). FXII-induced activation of FXI leads to the activation of FIX and FX, and eventually thrombin is formed. Thrombin leads to activation of platelets as well as the conversion of fibrinogen into fibrin. The formation of thrombin is greatly accelerated on the procoagulant surface (PS exposure) of activated platelets. The platelets assemble into a thrombus that is stabilized by fibrin. Positive feedback loops and anticoagulant factors are not indicated. For further details, see text. 
help of kallikrein and high molecular weight kininogen. The majority of prekallikrein in blood is bound to high molecular weight kininogen. High molecular weight kininogen functions as a cofactor as it simultaneously binds to prekallikrein and negatively charged surfaces. Binding of FXII to negatively charged surfaces leads to autoactivation. The conversion of prekallikrein to kallikrein is catalyzed by factor XIla and then kallikrein can activate factor XII again. ${ }^{43}$ In its active form factor XII activates factor $\mathrm{XI}$ and subsequently factor IX, which as described above results in factor $\mathrm{X}$ activation and thrombin formation. ${ }^{42}$ Traditionally, the tissue factor pathway is considered to be the most important initiator of coagulation since deficiency in factor VII or tissue factor is associated with severe hemorrhage ${ }^{44,45}$, while deficiency in FXII is not related to a bleeding phenotype. ${ }^{46}$ However, this concept was challenged by a report that factor XIIdeficient mice showed greatly reduced thrombus formation in various models of experimental arterial and venous thrombosis. ${ }^{47}$

Platelets stimulate coagulation by providing a phospholipid surface, at which coagulation factors can assemble and become activated. In resting platelets the procoagulant phospholipids, phosphatidylserine (PS) and phosphatidylethanolamine (PE) are present in the inner leaflet of the plasma membrane. Upon platelet activation PS and PE become exposed from the inner to the outer leaflet, likely by scramblase activity. ${ }^{48}$ Especially the negatively charged PS supports the $\mathrm{Ca}^{2+}$-dependent formation of the tenase complex, consisting of factors IXa and VIIla, and the prothrombinase complex with factors $\mathrm{Xa}$ and $\mathrm{Va}$. Co-localization of these procoagulant complexes on the platelet surface accelerates the formation of thrombin dramatically. It has been shown that PS exposure on the platelets is induced by a prolonged rise in intracellular $\mathrm{Ca}^{2+}$ concentration. ${ }^{8,49} \mathrm{Ca}^{2+}$ ionophore followed by complement membrane attack complex C5b-9 appeared to be most effective in evoking PS exposure. ${ }^{7}$ Early evidence already described that activation of platelets with the physiological agonists thrombin or collagen increased PS exposure moderately, but simultaneous stimulation with thrombin and collagen was very potent in causing PS exposure. ${ }^{6}$ At present, the thrombin receptor PAR1 and collagen receptor GPVI are believed to be the major receptors responsible for inducing platelet procoagulant activity. ${ }^{50-52}$ However, during in vivo thrombus formation few platelets become exposed to both thrombin and collagen and therefore it is likely that other agonists also are involved in platelet procoagulant activity. Additional agonists and signaling pathways remain to be elucidated.

\section{Aims and outline of the thesis}

This thesis focuses on novel interaction mechanisms of platelet signaling and coagulation which may play an important, hitherto undiscovered role in thrombosis and hemostasis. Following the introductory chapter 1, the role of platelets in venous and arterial thrombosis is discussed in a short review presented in chapter 2. Starting from the premise that activation of platelets and coagulation are cooperative processes; this review paper considers that platelets should play a role in venous thrombosis. In the next chapters, it was investigated by which mechanisms platelets can affect thrombin 
generation and coagulation. Insight into these processes can give information on the efficacy of antiplatelet treatment in the prevention of thrombosis. In chapter 3 the role of the platelet agonist, $A D P$, and of the purinergic $P 2 Y_{1}$ and $P 2 Y_{12}$ receptors was examined with regards to the procoagulant effect of platelets. For patients at thrombotic risk, the result of anti-P2 $\mathrm{Y}_{12}$ treatment was assessed on platelet-dependent thrombin generation using calibrated automated thrombography (CAT). This work revealed that ADP, acting via $\mathrm{P}_{2} \mathrm{Y}_{12}$, exerts a procoagulant effect particularly by enhancing $\mathrm{Ca}^{2+}$ fluxes in platelets. Chapter 4 subsequently describes a dual signaling mechanism, by which P2Y 12 can synergize with thrombin to increase the $\mathrm{Ca}^{2+}$ and procoagulant responses. Purinergic receptor stimulation leads to integrin $\alpha \operatorname{llb} \beta 3$ activation, while blockade of this integrin suppresses platelet-mediated procoagulant activity. In chapter $\mathbf{5}$ it was therefore investigated, by which signaling mechanism $\alpha$ llb $\beta 3$ is capable to contribute to the coagulation process. The second part of this thesis examines how collagen can contribute to the roles of platelets in thrombin generation and thrombus formation. In chapter $\mathbf{6}$ it is hypothesized that collagen has an additional function beyond stimulation of the platelet GPVI receptors. By using blood from mice deficient in coagulation factor XI or XII, or mice lacking signaling proteins of the GPVI cascade, it appeared that collagen in addition is capable to stimulate the intrinsic pathway of coagulation. The novel findings of this thesis are critically discussed in relation to the current literature in chapter 7 , where also possible clinical implications are described. 


\section{References}

1. Tan KT, Lip GY. Red vs white thrombi: treating the right clot is crucial. Arch Intern Med. 2003;163:2534-2535; author reply 2535.

2. Colman RW, Clowes AW, George JN, Hirsch J, Marder VJ. Overview in hemostasis. In: Hemostasis and thrombosis: basic principles \& clinical practice (Colman, R, Hirsch, J, Marder, V, Clowes, A, George, J, eds), Lippincott Williams \& Wilkins, Philadelphia (USA). 2001:3-16.

3. Ruggeri ZM. Platelets in atherothrombosis. Nat Med. 2002;8:1227-1234.

4. Butenas S, Cawthern KM, van 't Veer C, DiLorenzo ME, Lock JB, Mann KG. Antiplatelet agents in tissue factor-induced blood coagulation. Blood. 2001;97:2314-2322.

5. Furie B, Furie BC. Thrombus formation in vivo. J Clin Invest. 2005;115:3355-3362.

6. Bevers EM, Comfurius $P$, Zwaal RF. Changes in membrane phospholipid distribution during platelet activation. Biochim Biophys Acta. 1983;736:57-66.

7. Zwaal RF, Schroit AJ. Pathophysiological implications of membrane phospholipid asymmetry in blood cells. Blood. 1997;89:1121-1132.

8. Heemskerk JW, Bevers EM, Lindhout T. Platelet activation and blood coagulation. Thromb Haemost. 2002;88:186-193.

9. Hemker HC. Thrombin generation, an essential step in haemostasis and thrombosis. In: Haemostasis and thrombosis (Forbes, C, Thomas, D, Tuddenham, E, eds), Churchill Livingstone, Edinburgh (UK). 1994:477-490.

10. Coughlin SR. Protease-activated receptors in hemostasis, thrombosis and vascular biology. $\mathrm{J}$ Thromb Haemost. 2005;3:1800-1814.

11. Kahn ML, Nakanishi-Matsui M, Shapiro MJ, Ishihara H, Coughlin SR. Protease-activated receptors 1 and 4 mediate activation of human platelets by thrombin. J Clin Invest. 1999;103:879-887.

12. Xu WF, Andersen H, Whitmore TE, Presnell SR, Yee DP, Ching A, Gilbert T, Davie EW, Foster DC. Cloning and characterization of human protease-activated receptor 4. Proc Natl Acad Sci USA. 1998;95:6642-6646.

13. Kahn ML, Zheng YW, Huang W, Bigornia V, Zeng D, Moff S, Farese RV, Jr., Tam C, Coughlin SR. A dual thrombin receptor system for platelet activation. Nature. 1998;394:690694.

14. Vu TK, Hung DT, Wheaton VI, Coughlin SR. Molecular cloning of a functional thrombin receptor reveals a novel proteolytic mechanism of receptor activation. Cell. 1991;64:10571068.

15. Offermanns S. Activation of platelet function through $\mathrm{G}$ protein-coupled receptors. Circ Res. 2006;99:1293-1304.

16. Berridge MJ, Bootman MD, Roderick HL. Calcium signaling: dynamics, homeostasis and remodelling. Nat Rev Mol Cell Biol. 2003;4:517-529.

17. Sage SO. Calcium entry mechanisms in human platelets. Exp Physiol. 1997;82:807-823.

18. Heemskerk JW. Calcium and platelets. In: The molecular basis of calcium action in biology and medicin (Pochet, R, Donato, R, Haiech, J, Heinzamnn, C, Gerke, V, eds), Kluwer Acad Publ, The Hague (The Netherlands). 2000:45-71.

19. Hewavitharana T, Deng X, Soboloff J, Gill DL. Role of STIM and Orai proteins in the storeoperated calcium signaling pathway. Cell Calcium. 2007;42:173-182.

20. Liao Y, Erxleben C, Abramowitz J, Flockerzi V, Zhu MX, Armstrong DL, Birnbaumer L. Functional interactions among Orai1, TRPCs, and STIM1 suggest a STIM-regulated heteromeric Orai/TRPC model for SOCE/Icrac channels. Proc Natl Acad Sci USA. 2008;105:2895-2900.

21. Woulfe DS. Platelet G protein-coupled receptors in hemostasis and thrombosis. J Thromb Haemost. 2005;3:2193-2200. 
22. Hechler B, Cattaneo M, Gachet C. The P2 receptors in platelet function. Semin Thromb Hemost. 2005;31:150-161.

23. Kauffenstein G, Bergmeier W, Eckly A, Ohlmann P, Leon C, Cazanave JP, Nieswandt B, Gachet $C$. The $P 2 Y_{12}$ receptor induces platelet aggregation through weak activation of the $\alpha$ llb33 integrin - phosphoinositide 3-kinase-dependent mechanism. FEBS Lett. 2001;505:281290.

24. Dorsam RT, Kunapuli SP. Central role of the $P 2 Y_{12}$ receptor in platelet activation. J Clin Invest. 2004;113:340-345.

25. Jackson SF, Schoenwaelder SM. Type I phosphoinositide 3-kinases: potential antithrombotic targets? Cell Mol Life Sci. 2006;63:1085-1090.

26. Oury C, Toth-Zsamboki E, Thys C, Tytgat J, Vermylen J, Hoylaerts MF. The ATP-gated P2X ion channel acts as a positive regulator of platelet responses to collagen. Thromb Haemost. 2001;86:1264-1271.

27. Farndale RW, Sixma JJ, Barnes MJ, de Groot PG. The role of collagen in thrombosis and hemostasis. J Thromb Haemost. 2004;2:561-573.

28. Clemetson KJ, Clemetson JM. Platelet collagen receptors. Thromb Haemost. 2001;86:189197.

29. Nieswandt B, Watson SP. Platelet-collagen interaction: is GPVI the central receptor? Blood. 2003;102:449-461.

30. Watson SP, Auger JM, McCarty OJ, Pearce AC. GPVI and integrin $\alpha$ llb $\beta 3$ signaling in platelets. J Thromb Haemost. 2005;3:1752-1762.

31. Shattil SJ, Newman PJ. Integrins: dynamic scaffolds for adhesion and signaling in platelets. Blood. 2004;104:1606-1615.

32. Ginsberg MH, Partridge A, Shattil SJ. Integrin regulation. Curr Opin Cell Biol. 2005;17:509516.

33. Cosemans JM, Iserbyt BF, Deckmyn H, Heemskerk JW. Multiple ways to switch platelet integrins on and off. J Thromb Haemost. 2008;6:1253-1261.

34. Ma YQ, Qin J, Plow EF. Platelet integrin $\alpha$ llb $\beta 3$ : activation mechanisms. J Thromb Haemost. 2007;5:1345-1352.

35. Phillips DR, Nannizzi-Alaimo L, Prasad KS. $\beta 3$ tyrosine phosphorylation in $\alpha$ llb $\beta 3$ (platelet membrane GP IIb-IIla) outside-in integrin signaling. Thromb Haemost. 2001;86:246-258.

36. Shattil SJ, Kashiwagi $\mathrm{H}$, Pampori N. Integrin signaling: the platelet paradigm. Blood. 1998;91:2645-2657.

37. Mackman N, Tilley RE, Key NS. Role of the extrinsic pathway of blood coagulation in hemostasis and thrombosis. Arterioscler Thromb Vasc Biol. 2007;27:1687-1693.

38. Spronk HM, Govers-Riemslag JW, ten Cate H. The blood coagulation system as a molecular machine. Bioessays. 2003;25:1220-1228.

39. Mackman N. Role of tissue factor in hemostasis and thrombosis. Blood Cells Mol Dis. 2006;36:104-107.

40. Mann KG, Butenas S, Brummel K. The Dynamics of thrombin formation. Arterioscler Thromb Vasc Biol. 2003;23:17-25.

41. Pedicord DL, Seiffert D, Blat $Y$. Feedback activation of factor $X I$ by thrombin does not occur in plasma. Proc Natl Acad Sci USA. 2007;104:12855-12860.

42. Renné T, Nieswandt B, Gailani D. The intrinsic pathway of coagulation is essential for thrombus stability in mice. Blood Cells Mol Dis. 2006;36:148-151.

43. Colman RW. Contact activation pathway: Inflammatory, fibrinolytic, anticoagulant, antiadhesive and antiangiogenic activities. In: Hemostasis and thrombosis: basic principles \& clinical practice (Colman, R, Hirsch, J, Marder, V, Clowes, A, George, J, eds), Lippincott Williams \& Wilkins, Philadelphia (USA). 2001:103-121. 
44. Bugge TH, Xiao Q, Kombrinck KW, Flick MJ, Holmback K, Danton MJ, Colbert MC, Witte DP, Fujikawa K, Davie EW, Degen JL. Fatal embryonic bleeding events in mice lacking tissue factor, the cell-associated initiator of blood coagulation. Proc Natl Acad Sci USA. 1996;93:6258-6263.

45. Rosen ED, Chan JC, Idusogie E, Clotman F, Vlasuk G, Luther T, Jalbert LR, Albrecht S, Zhong L, Lissens A, Schoonjans L, Moons L, Collen D, Castellino FJ, Carmeliet P. Mice lacking factor VII develop normally but suffer fatal perinatal bleeding. Nature. 1997;390:290294.

46. Lammle B, Wuillemin WA, Huber I, Krauskopf M, Zurcher C, Pflugshaupt R, Furlan M. Thromboembolism and bleeding tendency in congenital factor XII deficiency - a study on 74 subjects from 14 Swiss families. Thromb Haemost. 1991;65:117-121.

47. Renne T, Pozgajova M, Gruner S, Schuh K, Pauer HU, Burfeind P, Gailani D, Nieswandt B. Defective thrombus formation in mice lacking coagulation factor XII. J Exp Med. 2005;202:271-281.

48. Bevers EM, Comfurius P, Dekkers DW, Zwaal RF. Lipid translocation across the plasma membrane of mammalian cells. Biochim Biophys Acta. 1999;1439:317-330.

49. Heemskerk JW, Siljander PR, Bevers EM, Farndale RW, Lindhout T. Receptors and signaling mechanisms in the procoagulant response of platelets. Platelets. 2000;11:301-306.

50. Keuren JF, Wielders SJ, Ulrichts H, Hackeng T, Heemskerk JW, Deckmyn H, Bevers EM, Lindhout T. Synergistic effect of thrombin on collagen-induced platelet procoagulant activity is mediated through protease-activated receptor-1. Arterioscler Thromb Vasc Biol. 2005;25:1499-1505.

51. Andersen H, Greenberg DL, Fujikawa K, Xu WF, Chung DW, Davie EW. Protease-activated receptor 1 is the primary mediator of thrombin-stimulated platelet procoagulant activity. Proc Natl Acad Sci USA. 1999;96:11189-11193.

52. Heemskerk JW, Kuijpers MJ, Munnix IC, Siljander PR. Platelet collagen receptors and coagulation. A characteristic platelet response as possible target for antithrombotic treatment. Trends Cardiovasc Med. 2005;15:86-92. 



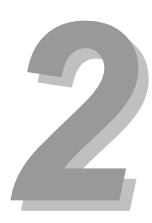

\section{Classification of venous thromboembolism (VTE). Platelets in venous thrombosis}

Paola E.J. van der Meijden, Johan W.M. Heemskerk, Karly Hamulyák and Hugo ten Cate

J Thromb Haemost 2005; 3: 2575-2577

Reprinted with permission 
The blood coagulation system serves at least two main functions in physiology: controlling bleeding due to trauma and protecting the organism against infections as part of the innate immune system. ${ }^{1}$ These functions are accomplished by multiple interactions between cellular elements (platelets, leukocytes and endothelial cells) and proteins of the coagulation and fibrinolytic pathways. In case of bleeding, the traditional view is that the cells provide the first line of defence, i.e. aggregated platelets form the primary hemostatic plug after which the coagulation process permits fibrin clot formation (secondary hemostasis). The modern view is slightly different in the sense that we consider these mechanisms as cooperative and acting in parallel, in fact behaving as an integrated cell-protein clotting machinery. Why and how, then, have platelets and the coagulation system still different functions?

Excessive activity of the blood coagulation system can result in excess fibrin formation at sites of blood stasis or vascular damage, where it is potentially harmful. This situation may lead to venous thrombosis, in which a fibrin and cellular meshwork partially or completely obstructs a major vein. On the other hand, rupture of an atherosclerotic plaque can result in arterial thrombosis. Thrombosis by itself is a cause of serious clinical complications; venous thrombosis leads to pulmonary embolism and post-thrombotic syndrome, while arterial thrombosis causes impaired oxygenation of a critical organ, resulting in e.g. a myocardial infarction or stroke.

From early studies by Virchov and other pathologists it is known that venous and arterial thrombi typically differ in their composition. While venous thrombi appear as 'red' clots due to numerous red cells intermingled with fibrin, arterial thrombi are 'white' in appearance due to a predominance of platelets with associated fibrin. ${ }^{2}$ Consequently, it has been surmised for long that particularly platelets play a distinct role in the thrombotic processes, in the sense that their participation is critically important in arterial thrombosis, but not apparent in venous thrombosis. ${ }^{3,4}$ This corresponds well to the experimental evidence ex vivo that tissue factor is a primary trigger for thrombus formation under (coagulant) conditions resembling those of venous thromboembolism. ${ }^{5}$ Also, at high shear-rate conditions, as in (stenotic) arteries, collagen with deposited von Willebrand factor (VWF) is known to be an initial trigger for platelet tethering and adhesion, which predisposes for the formation of platelet-rich thrombi with a typical 'arterial' composition. ${ }^{6,7}$ However, the recognition that also blood-borne tissue factor can promote for arterial thrombus formation ${ }^{8}$ has changed this black-white view.

Presently, we have considerable knowledge of the molecular mechanisms of the interactions of platelets and the coagulation system. ${ }^{9}$ Activated platelets expose procoagulant phospholipids, which enhance the generation of factor $\mathrm{Xa}$ and thrombin by several magnitudes. ${ }^{10}$ Since thrombin is one of the most potent platelet agonists, this procoagulant activity of platelets results in a positive feedback loop of platelet activation, thrombin generation and fibrin formation. ${ }^{11}$ Platelets already respond at very low (subnanomolar) concentrations of thrombin via their receptors (PARs), i.e. well before fibrin starts to be formed. It is thus inevitable that all platelets become in an activated state at sites of venous thrombosis, where locally quite high levels of thrombin can be reached. This would imply that platelet procoagulant activity is a potent driving force for the 
thrombin generation in venous thrombosis, although this has not yet been demonstrated. Thus, simply the fact that thrombin is formed in thrombotic veins predicts that platelets will contribute to the thrombotic process. All of this does not necessarily mean that weak platelet antagonists (like aspirin) effectively affect the thrombotic process; for instance, the tissue factor (blood-borne?) induced thrombin generation can locally be too high to be inhibited by weak antiplatelet agents whereas anticoagulant medication is still effective.

In experimental animal studies, the effect of platelet inhibitors on venous thrombosis indeed depends on the model chosen. In general, stasis-induced thrombi are insensitive to platelet inhibition, e.g. with aspirin, while inflammation related models (applying an inflammatory stimulus) may be more dependent on platelet function. ${ }^{3}$ The clearest influence of platelet inhibitors is observed in models where the venous wall is directly damaged by mechanical or other forces. Under those conditions, platelets likely interact with subendothelial collagen and VWF, facilitating their adherence and activation, while aspirin or ADP receptor blockers inhibit the venous thrombus formation. ${ }^{12}$ Thus, following the argumentation above, while thrombin will activate platelets at the thrombotic sites under all these conditions, platelet inhibitors seem to be most effective in situations where a direct trigger for platelet activation is present (LPS, collagen, vWF).

Translating these animal experiments to the clinical situation, the efficacy of antiplatelet therapy in venous thrombosis may similarly depend on the underlying cause. Thus, stasis dependent thrombosis during prolonged physical immobilization or gradual occlusion of a vein may be less inhibitable with platelet antagonists than trauma induced thrombosis.

Is this argumentation of any clinical relevance? We believe it is for the following reasons. First, there is an ongoing debate about the importance of platelet inhibitors in the prevention of venous thromboembolism (VTE), where advocates claim that the $37 \%$ or $53 \%$ risk reduction observed in a meta-analysis of platelet inhibition in preventing deep venous thrombosis and pulmonary embolisms, respectively, is highly relevant. ${ }^{13}$ In contrast, in a recent position paper other investigators indicate that this antithrombotic effect of platelets inhibitors is of limited clinical importance as compared to the more effective low molecular weight heparins. ${ }^{14}$ Here, better knowledge of the platelet triggers in relation to venous thrombosis under different conditions may help to clarify the clinical arguments. Also, the use of platelet antagonists with an anticoagulant effect such as clopidogrel $^{15,16}$ and integrin blockers ${ }^{17}$ should be considered. Second, and related, there is still a need for simple ways of preventing venous thrombosis in conditions like prolonged immobilization during long-term transportation such as flying. Here, it would be very helpful to estimate how effective aspirin (or perhaps even better other platelet inhibitors with anticoagulant effect) might be in limiting the risks, but it is unlikely that clinical trials will be able to answer the question, because of the low incidence of clinical VTE and consequently huge study samples required. Third, new proposals for classifying idiopathic $\mathrm{VTE}^{18}$ may take into account the likely presence of a platelet trigger.

Finally, to answer the question what is the role of platelets in venous thromboembolism? Most likely, this role is considerable, but effective inhibition may need 
the use of combination medication of anticoagulants and antiplatelet agents, particularly those which also have an anticoagulant potential such as clopidogrel and integrin blockers. 


\section{References}

1. Spronk HM, Govers-Riemslag JW, ten Cate H. The blood coagulation system as a molecular machine. Bioessays. 2003;25:1220-1228.

2. Tan KT, Lip GY. Red vs white thrombi: treating the right clot is crucial. Arch Intern Med. 2003;163:2534-2535; author reply 2535.

3. Ten Cate H, Aird WC. Lessons from venous thrombosis and disseminated intravascular coagulation: a synthesis of pathophysiological mechanisms of prothrombotic states. In: Molecular mechanisms of disseminated intravascular coagulation (Ten Cate, H, Levi, M, eds), Landes Bioscience, Georgetown (USA). 2003:7-28.

4. Ten Cate H, Brandjes DP, Smits PH, van Mourik JA. The role of platelets in venous thrombosis: a patient with Glanzmann's thrombasthenia and a factor $\mathrm{V}$ Leiden mutation suffering from deep venous thrombosis. J Thromb Haemost. 2003;1:394-395.

5. Mann KG, Jenny RJ, Krishnaswamy S. Cofactor proteins in the assembly and expression of blood clotting enzyme complexes. Annu Rev Biochem. 1988;57:915-956.

6. Ruggeri ZM. Platelets in atherothrombosis. Nat Med. 2002;8:1227-1234.

7. Nieswandt B, Brakebusch C, Bergmeier W, Schulte V, Bouvard D, Mokhtari-Nejad R, Lindhout T, Heemskerk JW, Zirngibl H, Fassler R. Glycoprotein VI but not $\alpha 2 \beta 1$ integrin is essential for platelet interaction with collagen. Embo J. 2001;20:2120-2130.

8. Giesen PLA, Rauch U, Bohrman B, Kling D, Roqué M, Fallon JT, Badimon JJ, Himber J, Riederer MA, Nemerson Y. Blood-borne tissue factor, another view of thrombosis. Proc Natl Acad Sci USA. 1999;96:2311-2315.

9. Heemskerk JW, Bevers EM, Lindhout T. Platelet activation and blood coagulation. Thromb Haemost. 2002;88:186-193.

10. Zwaal RF, Schroit AJ. Pathophysiological implications of membrane phospholipid asymmetry in blood cells. Blood. 1997;89:1121-1132.

11. Béguin S, Kumar R. Thrombin, fibrin and platelets, a resonance loop in which von Willebrand factor is a necessary link. Thromb Haemost. 1997;78:590-594.

12. van Gestel MA, Heemskerk JW, Slaaf DW, Heijnen VV, Reneman RS, oude Egbrink MG. In vivo blockade of platelet $A D P$ receptor $P 2 Y_{12}$ reduces embolus and thrombus formation but not thrombus stability. Arterioscler Thromb Vasc Biol. 2003;23:518-523.

13. Blann AB, Lip GY. Platelet involvement in venous thrombosis and pulmonary embolism. In: Platelets in thrombotic and non-thrombotic disorders (Gresele, P, Page, C, Fuster, V, Vermylen, J, eds), Cambridge University Press, Cambridge (UK). 2002:753-760.

14. Geerts WH, Pineo GF, Heit JA, Bergqvist D, Lassen MR, Colwell CW, Ray JG. Prevention of venous thromboembolism: the Seventh ACCP Conference on Antithrombotic and Thrombolytic Therapy. Chest. 2004;126:338S-400S.

15. Léon C, Ravanat C, Freund M, Cazenave JP, Gachet C. Differential involvement of the P2Y, and $\mathrm{P}_{2} \mathrm{Y}_{12}$ receptors in platelet procoagulant activity. Arterioscler Thromb Vasc Biol. 2003;23:1941-1947.

16. van der Meijden PE, Feijge MA, Giesen PL, Huijberts M, van Raak LP, Heemskerk JW. Platelet $P 2 Y_{12}$ receptors enhance signaling towards procoagulant activity and thrombin generation. A study with healthy subjects and patients at thrombotic risk. Thromb Haemost. 2005;93:1128-1136.

17. Reverter JC, Béguin S, Kessels H, Kumar R, Hemker HC, Coller BS. Inhibition of plateletmediated, tissue-factor-induced thrombin generation by the mouse/human chimeric 7E3 antibody. Potential implications for the effect of c7E3 Fab treatment on acute thrombosis and 'clinical restenosis'. J Clin Invest. 1996;98:863-874.

18. White $\mathrm{H}$, Murin $\mathrm{S}$. Is the current classification of venous thromboembolism acceptable? No. $J$ Thromb Haemost. 2004;2:2262-2263. 



\section{Platelet $\mathrm{P}_{2} \mathrm{Y}_{12}$ receptors enhance}

signaling towards procoagulant activity

\section{and thrombin generation.}

A study with healthy subjects and patients at thrombotic risk 


\begin{abstract}
Activated platelets participate in arterial thrombosis by forming aggregates and potentiating the coagulation through exposure of procoagulant phosphatidylserine. The function of the two receptors for $A D P, P 2 Y_{1}$ and $P 2 Y_{12}$, is well-established in aggregation, but is incompletely understood in the platelet procoagulant response. We established that, in PRP from healthy subjects, ADP accelerated and potentiated tissue factor-induced thrombin generation exclusively via stimulation of $P_{2} Y_{12}$ and not via $P 2 Y_{1}$ receptors. The $\mathrm{P} 2 \mathrm{Y}_{12}$ receptors also mediated the potentiating effect of PAR1 stimulation on thrombin generation. Furthermore, ADP enhanced in a $\mathrm{P}_{2} \mathrm{Y}_{12}$-dependent manner the $\mathrm{Ca}^{2+}$ response induced by thrombin, which was either added externally or generated insitu. This ADP effect was in part dependent of phosphoinositide 3-kinase and was paralleled by increased phosphatidylserine exposure. In PRP from (young) patients with either stroke or type-Il diabetes, platelet-dependent thrombin generation was similarly enhanced by ADP or SFLLRN as in healthy subjects. In PRP from stroke patients of older age, the $\mathrm{P} 2 \mathrm{Y}_{12}$-mediated contribution to thrombin generation was variably reduced by two weeks of clopidogrel medication. Remaining P2Y 12 activity after medication correlated with remaining $\mathrm{P}_{2} \mathrm{Y}_{12}$-dependent $\mathrm{P}$-selectin exposure, i.e. $\mathrm{Ca}^{2+}$-dependent secretion, likely due to incomplete antagonism of $\mathrm{P}_{2} \mathrm{Y}_{12}$ receptors. Together, these results indicate that physiological platelet agonists amplify phosphatidylserine exposure and subsequent thrombin generation by release of $A D P$ and $\mathrm{P}_{2} \mathrm{Y}_{12}$-receptor stimulation. This $\mathrm{P}_{2} \mathrm{Y}_{12}$ response is accomplished by a novel $\mathrm{Ca}^{2+}$ signaling pathway. It is similarly active in platelets from control subjects and patients at thrombotic risk. Finally, the thrombogram method is useful for measuring incomplete $\mathrm{P}_{2} \mathrm{Y}_{12}$ inhibition with clopidogrel.
\end{abstract}

\title{
Introduction
}

Platelet activation and blood coagulation are mutually stimulatory processes in hemostasis and thrombosis. ${ }^{1,2}$ When stimulated with agonists that cause a prolonged elevation in cytosolic $\left[\mathrm{Ca}^{2+}\right]_{i}$ such as collagen or calcium ionophore, platelets respond by exposing procoagulant phosphatidylserine (PS) at their outer surface. ${ }^{3}$ The resulting PSexposing membrane provides assembly sites for tenase and prothrombinase complexes from the coagulation system, which result in a vast acceleration of thrombin generation. ${ }^{4}$ Conversely, once formed, thrombin is a potent physiological agonist, acting through the platelet $\mathrm{Gq} / 12$-coupled receptors, PAR1 and PAR4. ${ }^{5}$ Most likely because thrombin induces only transient, spiking $\mathrm{Ca}^{2+}$ mobilisation in platelets, ${ }^{6}$ by itself it is no more than weakly active in causing PS exposure and stimulating prothrombinase activity. ${ }^{4,7}$

Recent evidence indicates that release of endogenously stored ADP is a key event in platelet aggregation in response to physiological agonists such as thrombin or collagen. $^{8,9}$ The pro-aggregatory effect of ADP in platelets involves two purinergic receptors, $\mathrm{P} 2 \mathrm{Y}_{1}$ and $\mathrm{P} 2 \mathrm{Y}_{12}{ }^{10,11}$ The same receptors mediate the formation of platelet thrombi in blood flowing over a collagen surface. ${ }^{12,13} \mathrm{P} 2 \mathrm{Y}_{1}$, which is coupled to $\mathrm{Gq}$ (similarly as PAR1 and PAR4) triggers the classical pathway of intracellular $\mathrm{Ca}^{2+}$ 
mobilisation and subsequent store-regulated $\mathrm{Ca}^{2+}$ influx by activating phospholipase $\mathrm{C} \beta$. The $\mathrm{P}_{2} \mathrm{Y}_{12}$ receptor acts via a Gi-coupled pathway that inhibits adenylyl cyclase and, as a result, lowers cyclic-AMP levels. Similarly as with adrenaline, this cyclic-AMP lowering can result in increased $\mathrm{Ca}^{2+}$ signal generation. ${ }^{14}$ In addition, $\mathrm{P}_{2} \mathrm{Y}_{12}$ stimulates a phosphatidyl inositol 3-kinase (PI3-K) pathway, putatively involving the $\gamma$-isoform of PI3$\mathrm{K}$, which is known to be activated by $\beta \gamma$ regulatory subunits released from Gi $\alpha .{ }^{15}$ Activity of $\mathrm{PI} 3-\mathrm{K}$ completes the ADP-induced aggregation by enhancing the secretion reaction and activating integrin $\alpha \mathrm{llb} \beta 3{ }^{9,16}$

A number of earlier and recent studies indicate that ADP release and $P 2 Y_{12}$ receptor stimulation contribute to thrombin generation and coagulation. ${ }^{17-20}$ This finding raises a number of important questions. Because during the coagulation process high levels of thrombin are formed, which are sufficiently high to fully activate both PAR1 and PAR4, it is unclear how the released ADP can bypass or enhance the effects of PAR stimulation on platelets. Further, since platelet procoagulant activity is a $\mathrm{Ca}^{2+}$-dependent process, it is tempting to infer that ADP contributes to thrombin generation by increased $\mathrm{Ca}^{2+}$ signaling, but whether this is indeed the case and by which signaling pathways, are questions that are still unanswered. Another unresolved issue is whether or not ADP contributes to coagulant activity by surface exposure of PS or integrin activation. ${ }^{17,18,21}$ Better knowledge of the mechanism of ADP-stimulated procoagulant activity is of considerable interest, as $\mathrm{P}_{2} \mathrm{Y}_{12}$ is the target of antithrombotic drugs like clopidogrel. ${ }^{22-24}$

Clopidogrel is currently administered as a substitute for aspirin to patients with increased atherothrombotic risk. Differently from inhibiting thromboxane formation with aspirin, clopidogrel treatment may reduce not only platelet aggregation, but also plateletdependent coagulant activity. There is evidence for the presence of hyperactive platelets with increased procoagulant activity in patients with ischemic stroke. ${ }^{25}$ Similarly, increased platelet reactivity, e.g. via ADP receptors, may contribute to the hypercoagulable state in type-Il diabetes mellitus. ${ }^{26}$ This suggests that anti-P2Y $\mathrm{Y}_{12}$ medication would be particular helpful for these patients. On the other hand, recent aggregation measurements indicate that the inhibitory effect of clopidogrel intake is not always complete, but the effect on $\mathrm{P}_{2} \mathrm{Y}_{12}$-mediated procoagulant activity was not investigated. $^{27}$

Here, we investigated the procoagulant effect of ADP receptors under conditions of coagulation using the newly developed thrombogram method, which allows continuous measurement of the thrombin generation in coagulating platelet-rich plasma (PRP) ${ }^{28} \mathrm{We}$ found that $A D P$, exclusively acting via $\mathrm{P}_{2} \mathrm{Y}_{12}$, stimulated the thrombin-forming process by a hitherto unrecognised $\mathrm{Ca}^{2+}$ response and stimulation of $\mathrm{PS}$ exposure. In platelets from patients with stroke or type-II diabetes mellitus, P2 $_{12}$ caused an unchanged, enhancing effect on thrombin generation which, however, was quite variably suppressed by clopidogrel intake. 


\section{Materials and methods}

\section{Subjects}

For comparative thrombin generation studies, blood was taken from 11 healthy subjects, who were free from medication for at least two weeks. Blood was also taken from 11 young patients with stroke, aged 32 to 51 years (median 47 years). Other blood samples were obtained from 9 stroke patients of older age, i.e. 60 to 74 years (median 65 years), who were subsequently advised to take clopidogrel for two weeks (75 mg daily); a second blood sample was obtained at the end of this period to monitor the efficacy of this intervention. These patients had experienced an ischemic stroke at 3-12 months earlier (lesion proven by computer tomography or magnetic resonance imaging). Stroke patients did not use anti-platelet or anti-coagulant medication other than aspirin; 8 out of 9 older patients and 9 out of 11 young patients used statins. Finally, blood was taken from 12 patients with confirmed type-II diabetes mellitus, aged 26 to 73 years (median 56 years). All participating subjects gave full informed consent. The studies were approved by the local medical ethical committee.

\section{Materials}

ADP, apyrase, bovine serum albumin (BSA), adrenaline, thrombin, MRS2179 (MRS) and wortmannin were obtained from Sigma (St. Louis, MO, USA). PAR1 peptide SFLLRN and fluorescent thrombin substrate, Z-Gly-Gly-Arg aminomethyl coumarin (Z-GGRAMC), were from Bachem (Bubendorf, Switzerland). Recombinant human tissue factor was from Dade Behring (Marburg, Germany); acetylsalicylic acid (aspirin) from Genfarma (Maarssen, The Netherlands); Fura-2 pentaacetoxymethyl ester (Fura-2 AM) from Molecular Probes (Leiden, The Netherlands). AR-C69931MX (AR-C) was kindly provided by Astra-Zeneca (Charnwood, UK). Fluorescent-labelled and unlabelled annexin-A5 were obtained from Nexins Research (Hoeven, The Netherlands). Monoclonal antibody against $\mathrm{P}$-selectin labelled with fluorescein isothiocyanate (antiCD62P FITC) came from Immunotech (Marseille, France); FITC-labelled antibody PAC-1 against activated integrin $\alpha$ llb $\beta 3$ was from Becton Dickinson (San Jose, CA, USA). Human thrombin calibrator was from Thrombinoscope (Maastricht, The Netherlands); ancrod came from NIBSC (Hertfordshire, UK).

\section{Isolation of platelets}

Blood was drawn with a 1.2-mm needle, dripping freely into open tubes (first $2.5 \mathrm{~mL}$ of blood was discarded), and collected in $1 / 10$ volume of $129 \mathrm{mM}$ trisodium citrate. PRP was obtained by $15-\mathrm{min}$ centrifuging at $240 \mathrm{~g}$. Platelet-poor plasma (PPP) was prepared by centrifuging PRP twice at $2630 \mathrm{~g}$ for $10 \mathrm{~min}$. Platelet count in PRP was determined with a thrombocounter (Coulter Electronics, Luton, UK) and normalised with autologous PPP.

To obtain washed platelets, blood was collected into $1 / 6$ volume of acid-glucose solution (ACD, $80 \mathrm{mM}$ trisodium citrate, $52 \mathrm{mM}$ citric acid and $180 \mathrm{mM}$ glucose). PRP, 
prepared by centrifugation, was incubated with $2.5 \mu \mathrm{M}$ Fura- $2 \mathrm{AM}$ at $37^{\circ} \mathrm{C}$ for $45 \mathrm{~min}$. After addition of ACD solution and apyrase $(0.1 \mathrm{U} / \mathrm{mL}$ ADPase), platelets were centrifuged at $800 \mathrm{~g}$ for $15 \mathrm{~min}$, and after a wash step resuspended in Hepes buffer $\mathrm{pH}$ 7.45 (10 mM Hepes, $136 \mathrm{mM} \mathrm{NaCl}, 2.7 \mathrm{mM} \mathrm{KCl}, 2 \mathrm{mM} \mathrm{MgCl} 2,0.1 \%$ glucose and $0.1 \%$ BSA).

\section{Thrombin generation measurements}

Normalised PRP was preincubated with indicated inhibitors and/or activators. After 10 min, coagulation was initiated with tissue factor $/ \mathrm{CaCl}_{2}$, and thrombin generation was continuously measured at $37^{\circ} \mathrm{C}^{19}$ Briefly, $80 \mu \mathrm{L}$ of PRP $\left(150 \times 10^{9}\right.$ platelets/L) were pipetted into a polystyrene 96-wells plate (Immulon 2HB, Dynex Technologies, Chantilly, VA, USA). Wells contained $20 \mu \mathrm{L}$ tissue factor (6 pM) in buffer A (20 mM Hepes, $140 \mathrm{mM}$ $\mathrm{NaCl}$ and $5 \mathrm{mg} / \mathrm{mL} \mathrm{BSA}$ at $\mathrm{pH} 7.35$ ). The plate was pre-heated to $37^{\circ} \mathrm{C}$ for $5 \mathrm{~min}$ in a fluorescence well-plate reader. Coagulation was started by adding $20 \mu \mathrm{L}$ of Z-GGR-AMC (2.5 mM), dissolved in buffer $B(20 \mathrm{mM}$ Hepes, $140 \mathrm{mM} \mathrm{NaCl}, 100 \mathrm{mM} \mathrm{CaCl}, 60 \mathrm{mg} / \mathrm{mL}$ $\mathrm{BSA}$ at $\mathrm{pH}$ 7.35). After $10 \mathrm{~s}$ shaking, fluorescence from cleaved AMC was measured at excitation and emission wavelengths of 368 and $460 \mathrm{~nm}$, respectively. Fluorescence measurements were with a Fluoroskan Ascent well-plate reader (Themolab Systems, Helsinki, Finland), equipped with Thrombinoscope software. An internal thrombin calibrator was used to give corrected curves of thrombin generation. ${ }^{29}$ Alternatively, where indicated, fluorescence accumulation was measured with a Spectramax well-plate reader (Molecular Devices, Sunnyvale, CA, USA). In this case, first-derivative traces were directly converted into nanomolar concentrations of thrombin, ${ }^{28}$ by post-hoc calibration based on normal pool plasma. Peak height, time-to-peak and area-under-thecurve (i.e., endogenous thrombin potential, ETP) were used as principal parameters determining thrombin generation curves.

\section{Cytosolic $\mathrm{Ca}^{2+}$ measurements}

Washed, Fura-2 loaded platelets, diluted in Hepes buffer $\mathrm{pH} 7.45$ to $100 \times 10^{9}$ platelets/L, were used for $\left[\mathrm{Ca}^{2+}\right]_{i}$ measurements, as described elsewhere. ${ }^{30}$ Before administrating agonist, $1 \mathrm{mM} \mathrm{CaCl} 2$ was added. Changes in Fura-2 fluorescence were measured under stirring at 340 and $380 \mathrm{~nm}$ excitation by ratio fluorometry. After correction for background fluorescence, ratio values were converted into levels of $\left[\mathrm{Ca}^{2+}\right]$; ; both maximal rises in $\left[\mathrm{Ca}^{2+}\right]_{i}$ and $\left[\mathrm{Ca}^{2+}\right]_{\mathrm{i}}$-time integrals (5 min) were determined. ${ }^{6}$

\section{Flow cytometry}

Washed platelets $\left(100 \times 10^{9}\right.$ platelets/L) were resuspended in citrate plasma that was defibrinated by treatment with $14 \mu \mathrm{L}$ ancrod $(10 \mathrm{U} / \mathrm{mL})$. Coagulation was triggered with $\mathrm{CaCl}_{2}(16.6 \mathrm{mM})$; tissue factor $(5 \mathrm{pM})$ was added, as indicated. Exposure of PS was determined with flow cytometry after 11 min of activation, using FITC-labelled annexin A5. ${ }^{21}$ Flow cytometry was also used to measure P-selectin exposure and integrin $\alpha$ llb $\beta 3$ activation, using FITC-labelled anti-CD62 and FITC-labelled PAC-1 antibodies, 
respectively. ${ }^{31}$ PRP $\left(300 \times 10^{9}\right.$ platelets/L) was 10 -times diluted with Hepes buffer $\mathrm{pH}$ 7.45 and activated with indicated agonists for $10 \mathrm{~min}$.

\section{Statistics}

Statistical analysis was performed using the independent-samples t-test to compare independent variables, and the paired-samples t-test to compare effects of interventions. SPSS 11.0 software was used. Data are presented as means \pm SEM. However, where data from various individuals were compared, data are given as means \pm SD.

\section{Results}

\section{Enhancement of thrombin generation by PAR1 or ADP receptor stimulation is exclusively mediated by $P 2 Y_{12}$ receptor}

Recent reports indicate that thrombin generation in coagulating PRP is in part mediated by ADP release and $\mathrm{P}_{2} \mathrm{Y}_{12}$ stimulation. ${ }^{18,19}$ To confirm this, effects of ADP receptor antagonists on thrombin generation curves were determined in citrate PRP from healthy subjects that was triggered with $\mathrm{CaCl}_{2}$ and a low concentration of tissue factor (1 pM). Preincubation of PRP with the selective $\mathrm{P}_{2} \mathrm{Y}_{12}$ antagonist AR-C diminished and delayed the time-to-peak of thrombin formation from $24 \pm 1.3$ to $30 \pm 2.1$ min (mean $\pm S E M, n=5$ ) (Fig. 1A). Similar effects were obtained at doses of 1-30 $\mu \mathrm{M}$ AR-C, in agreement with the high affinity of this compound for $\mathrm{P}_{2} \mathrm{Y}_{12}\left(10^{-9} \mathrm{M}\right.$ range). In contrast, the $\mathrm{P}_{2} \mathrm{Y}_{1}$ antagonist MRS, which has a lower receptor affinity and was therefore used at higher concentrations $(50-200 \mu \mathrm{M})$, was unable to suppress thrombin generation, but even caused weak stimulation. An explanation for the lack of inhibitory effect of P2Y antagonism by MRS could be its low affinity or fast desensitisation of the receptor under coagulant conditions. To check this, platelet shape change (which is a P2Y ${ }_{1}$-mediated response) was monitored by turbidometry under the same experimental conditions. Addition of MRS $(50 \mu \mathrm{M})$ resulted in $50 \%$ reduction of the shape change occurring immediately at the onset of coagulation (PAR1 activity likely accounting for the remaining shape change). This indicates that released ADP can trigger for $\mathrm{P}_{2} \mathrm{Y}_{1}$ signaling in thrombin-generating plasma.

Thrombin generation in PRP can be enhanced by prior stimulation of platelet PAR1 with SFLLRN. ${ }^{19}$ We examined whether endocrine ADP contributes to this enhancement. Pretreatment of PRP with AR-C but not with MRS resulted in substantial antagonism of the potentiating effect of $15 \mu \mathrm{M}$ SFLLRN (Fig. 1B). Activation with SFLLRN significantly shortened the time-to-peak with $13 \pm 2.9 \%$ (mean $\pm S E M, n=10$ ), while conversely AR-C but not MRS prolonged the time-to-peak with $27 \pm 4.7 \%$. The latter effect was seen both with and without SFLLRN (Fig. 1C,D). These results indicate that a considerable part of the enhanced thrombin generation by PAR1 stimulation is de facto mediated by ADP release and $\mathrm{P} 2 \mathrm{Y}_{12}$ activity. 
A
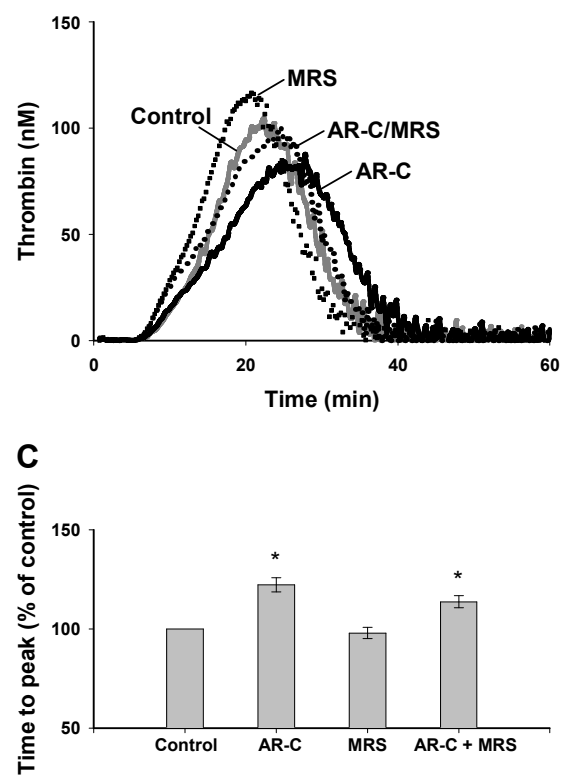

B
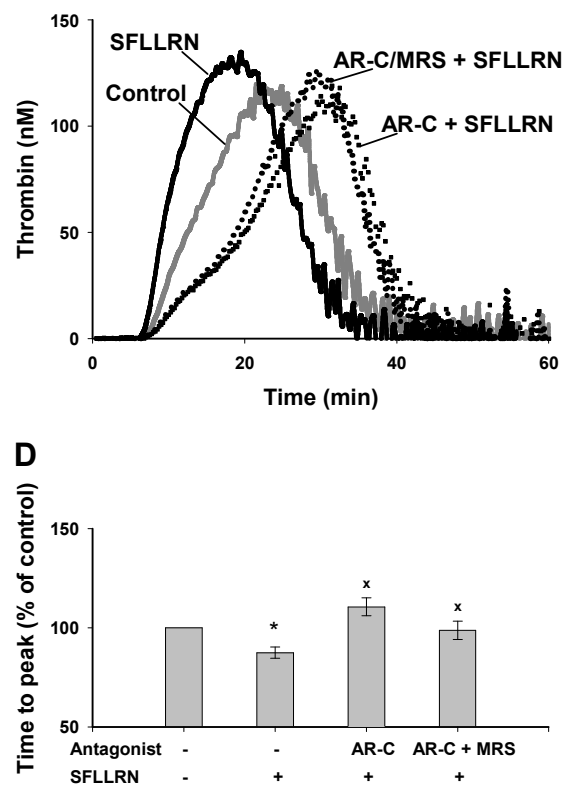

Figure 1. Contribution of autocrine ADP to enhancement of thrombin generation by PAR1 stimulation. PRP $\left(150 \times 10^{9}\right.$ platelets/L) from healthy subjects was preincubated with vehicle (control), AR-C69931MX (AR-C, $30 \mu \mathrm{M}$ ) and/or MRS2179 (MRS, $50 \mu \mathrm{M})$ for $15 \mathrm{~min}$, as indicated. The PRP was then stimulated with SFLLRN $(15 \mu \mathrm{M})$ or vehicle (control) for $10 \mathrm{~min}$. Thrombin generation was measured in the presence of Z-GGR-AMC (0.42 mM, f.c.), $\mathrm{CaCl}_{2}(16.6 \mathrm{mM})$ and tissue factor $(1.0 \mathrm{pM})$. Shown are representative, calibrated thrombin generation curves in the absence (A) or presence (B) of SFLLRN. (C,D) Quantitative effect of ADP on time-to-peak values relative to the control condition. Data are means \pm SEM $(n=5-10),{ }^{*} p \leq 0.05$ vs. condition without antagonist, ${ }^{x} \mathrm{p} \leq 0.05$ vs. condition with SFLLRN.

In following experiments, PRP was activated with ADP itself and the effect on thrombin generation was measured. Sub-maximal enhancing effects were obtained with ADP at a concentration of $20 \mu \mathrm{M}$, causing a $30 \pm 1.5 \%$ increase in thrombin peak height and a $25 \pm 3.1 \%$ shortening in time-to-peak (Fig. 2A,B). Preincubation with $30 \mu \mathrm{M}$ AR-C abolished the ADP effect, while MRS was ineffective. Notably, MRS still failed to inhibit, when administered at a 50x higher concentration than ADP. Preincubation of PRP with 1 $\mu \mathrm{M}$ wortmannin, an inhibitor of the PI3-K pathway implicated in $\mathrm{P}_{2} \mathrm{Y}_{12}$ signaling, ${ }^{9}$ also antagonised the ADP effect on thrombin generation; peak levels reduced with $22 \pm 9.5 \%$. Furthermore, preincubation with PS-scavenging annexin-A5 abrogated all (ADP effects on) thrombin formation (Fig. 2A).

Unlike reported by others, ${ }^{18}$ we were unable to detect surface exposure of PS on washed platelets that were stimulated with thrombin. However, when thrombin formation in defibrinated PRP was triggered with $\mathrm{CaCl}_{2}$, platelets readily exposed $\mathrm{PS}$, as detected with FITC-labelled annexin A5 (Fig. 2C). Addition of ADP increased the fraction of PSexposing platelets, while AR-C abrogated this ADP effect. When thrombin formation was 
A
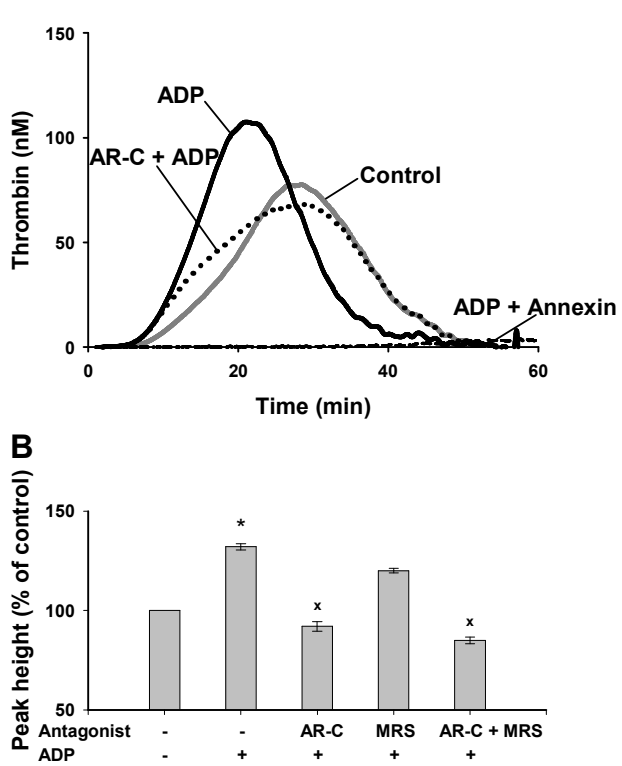

C
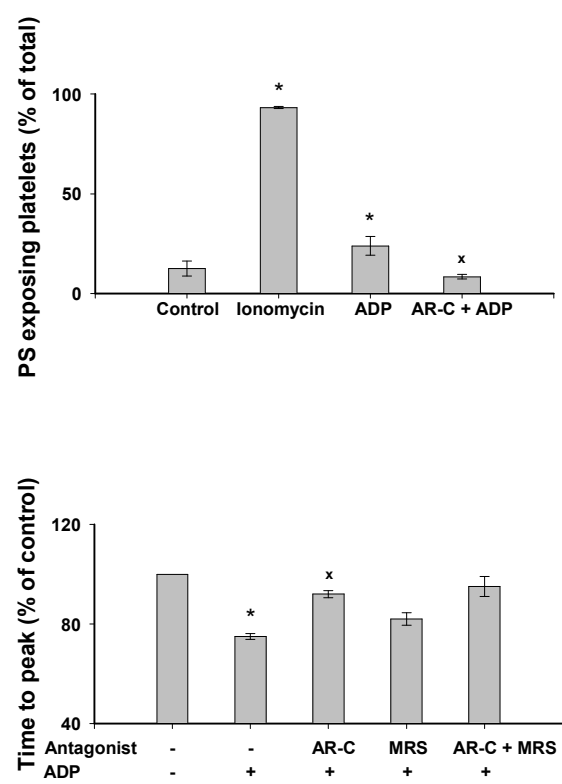

Figure 2. $P 2 Y_{12}$ receptor mediates enhancing effect of $A D P$ on thrombin generation by increasing PS exposure. (A) Effect of AR-C $(30 \mu \mathrm{M})$ or annexin-A5 $(10 \mu \mathrm{g} / \mathrm{mL})$ on ADP-enhanced thrombin generation. PRP was stimulated with ADP $(20 \mu \mathrm{M})$, and thrombin generation was measured after triggering with tissue factor/ $/ \mathrm{CaCl}_{2}$. (B) Quantitative effect of AR-C and MRS on thrombogram parameters. Data are expressed as percentages relative to the control condition without (ant)agonist (mean $\pm S E M, n=4-7$ ). (C) ADP-enhanced PS exposure during thrombin generation. Platelets in defibrinated plasma were untreated or activated with $20 \mu \mathrm{M}$ of ADP or ionomycin before triggering with $\mathrm{CaCl}_{2}$. Exposure of $\mathrm{PS}$ was determined by flow cytometry using

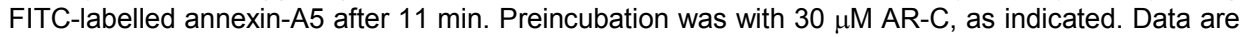
means \pm SEM $(n=4)$. ${ }^{*} p \leq 0.05$ vs. condition without (ant)agonist, ${ }^{x} p \leq 0.05$ vs. condition with ADP.

enhanced with tissue factor, the fraction of PS-exposing platelets became higher, but the effects of ADP and AR-C were maintained (data not shown). Together, these results indicate that the potentiating effect of $\mathrm{P}_{2} \mathrm{Y}_{12}$ signaling on thrombin generation is likely due to increased platelet activation and PS exposure.

\section{Stimulation of $P 2 Y_{12}$ potentiates thrombin-induced calcium signaling}

As prolonged elevation in cytosolic $\left[\mathrm{Ca}^{2+}\right]_{i}$ is needed for PS exposure, ${ }^{3}$ we studied the effect of $A D P$ on thrombin-evoked $\mathrm{Ca}^{2+}$ responses using Fura-2-loaded platelets. Fig. 3A shows that $A D P$, at a maximally effective dose of $20 \mu \mathrm{M}$, increased and prolonged the rise in $\left[\mathrm{Ca}^{2+}\right]_{i}$ induced by thrombin $(4 \mathrm{nM})$. Preincubation of platelets with AR-C $(30 \mu \mathrm{M})$, alone or in combination with MRS (50-200 $\mu \mathrm{M})$, completely abolished this ADP effect (Fig. 3B). In agreement with earlier results, ${ }^{32}$ AR-C preincubation also decreased the $\mathrm{Ca}^{2+}$ response evoked by ADP alone. Quantitative analysis indicated that AR-C lowered the maximal and integrated $\left[\mathrm{Ca}^{2+}\right]_{\mathrm{i}}$ rises evoked by thrombin with $17 \pm 4.3 \%$ and 
A
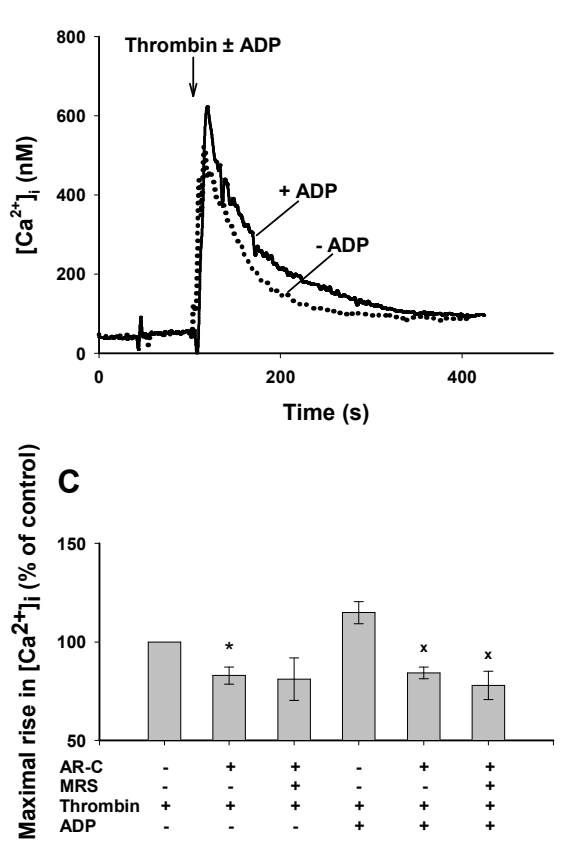

B
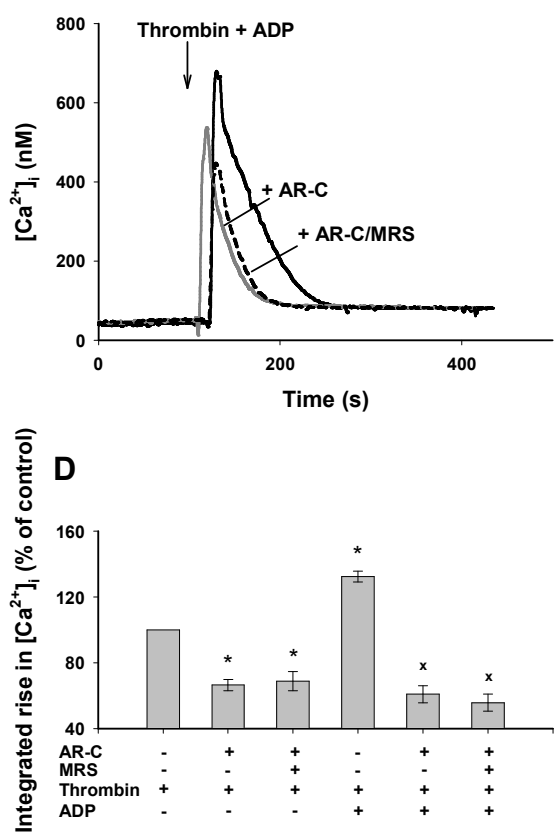

Figure 3. ADP enhances thrombin-induced $\mathrm{Ca}^{2+}$ response via $\mathrm{P}_{2} \mathrm{Y}_{12}$ stimulation. (A) Fura-2loaded platelets were activated with thrombin $(4 \mathrm{nM})$ with/without ADP $(20 \mu \mathrm{M})$ (arrow). (B) Platelets were preincubated with AR-C $(30 \mu \mathrm{M})$ with/without MRS $(50 \mu \mathrm{M})$, and subsequently activated with thrombin and ADP. Representative traces are given of changes in $\left[\mathrm{Ca}^{2+}\right]_{i} .(\mathrm{C}, \mathrm{D})$ Shown is stimulating effect of ADP on maximal $\left[\mathrm{Ca}^{2+}\right]_{i}$ rise and on $\left[\mathrm{Ca}^{2+}\right]$-time integral. Data are means \pm SEM $(n=3-5)$ relative to the condition of thrombin alone. ${ }^{*} p \leq 0.05$ vs. condition with thrombin, ${ }^{x} p \leq 0.05 v s$. condition with thrombin and ADP.

$34 \pm 3.4 \%$, whereas it reduced the $\left[\mathrm{Ca}^{2+}\right]$ i rises evoked by thrombin plus ADP with $25 \pm 2.8$ and $53 \pm 5.6 \%$, respectively (Fig. 3C,D). Notably, the potentiating effect of ADP persisted at thrombin concentrations as high as $40 \mathrm{nM}$ : integrated $\left[\mathrm{Ca}^{2+}\right]_{i}$ rises then increased with $22 \%$ in comparison to those of thrombin alone.

To approach conditions of coagulation, $\left[\mathrm{Ca}^{2+}\right]_{i}$ rises were also measured during in situ thrombin generation. Fura-2-loaded platelets were incubated with a mixture of tissue factor, factor VII, factor $X$ and prothrombin. The resulting continuous formation of thrombin caused a gradual increase in $\left[\mathrm{Ca}^{2+}\right]_{i}$ (Fig. 4A). Addition of ADP again enhanced the $\mathrm{Ca}^{2+}$ response, once more in a P2Y 12 manner (Fig. 4A,B). This ADP effect was most probably not mediated by a Gi-mediated decrease in cyclic-AMP level, because preincubation with $10 \mu \mathrm{M}$ adrenaline, sufficient to cause maximal lowering of cyclic$A M P,{ }^{14}$ did not influence the ADP stimulation of the $\mathrm{Ca}^{2+}$ signal with thrombin: ADP addition increased the maximal and integrated $\left[\mathrm{Ca}^{2+}\right]_{i}$ rises with $15 \%$ and $29 \%$, respectively, in comparison to thrombin/adrenaline. On the other hand pretreatment with $100 \mathrm{nM}$ wortmannin, inhibiting PI3-K, partly abolished the stimulating effect of ADP: 
A

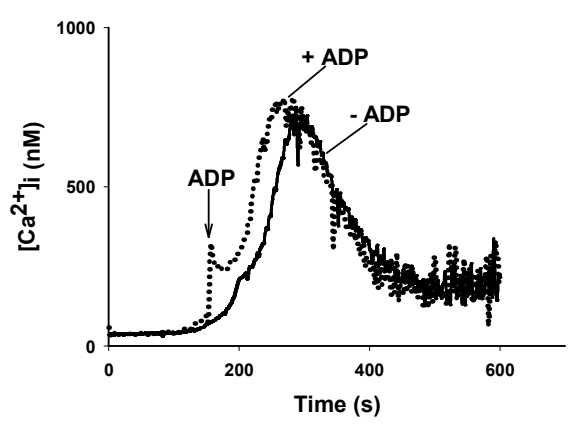

B

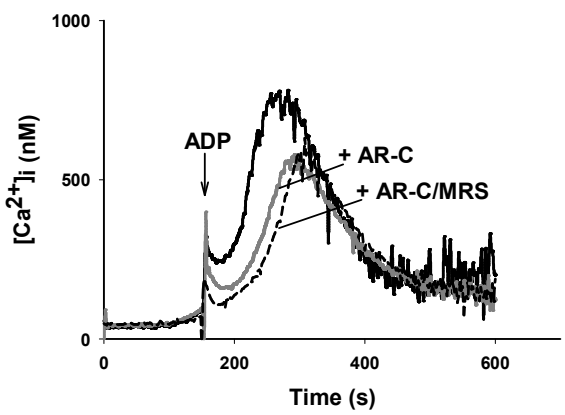

Figure 4. ADP enhances $\mathrm{Ca}^{2+}$ responses induced by thrombin generated in situ. Fura-2-loaded platelets were incubated with a mixture of tissue factor $(10 \mathrm{pM})$, factor $\mathrm{VII}(10 \mathrm{pM})$, factor $\mathrm{X}$ $(100 \mathrm{nM})$ and prothrombin $(1 \mu \mathrm{M})$, and changes in $\left[\mathrm{Ca}^{2+}\right]_{i}$ were measured. Thrombin generation was triggered with $\mathrm{CaCl}_{2}(t=0)$, after which ADP $(20 \mu \mathrm{M})$ or vehicle was added (arrow). (A) Representative traces of effect of ADP on $\mathrm{Ca}^{2+}$ response; (B) effect of preincubation with $30 \mu \mathrm{M}$ AR-C and/or $50 \mu \mathrm{M}$ MRS. Thrombin concentrations after 5 and 10 min amounted to 10 and $36 \mathrm{nM}$, respectively.

when compared to ADP/thrombin alone, maximal and integrated $\left[\mathrm{Ca}^{2+}\right]_{i}$ rises decreased with $7 \pm 4.6 \%$ and $24 \pm 6.1 \%$, respectively.

\section{Unaltered enhancement of thrombin generation by ADP in PRP from patients with stroke or diabetes mellitus}

To determine possibly altered ADP effects on platelet procoagulant activity, thrombin generation was measured in PRP from groups of young and older patients with stroke and PRP from patients with type-II diabetes mellitus. In the absence of ADP, tissue factor-triggered thrombin generation (thrombin peak level or area-under the curve) was higher in PRP from the older patients with stroke and in PRP from diabetic patients, in comparison to a group of healthy subjects (Table 1). As we have indicated before, interindividual variation in thrombogram characteristics is mostly explained by variation in plasma coagulant activity, and no more than little by variable platelet activation. ${ }^{19}$ Therefore, to determine possible variation in agonist-induced platelet procoagulant activity, thrombogram curve shifts were examined after preactivation of the PRP with ADP or SFLLRN. On average, in all groups, these agonists caused a similar increase in thrombin peak height and a similar decrease in time-to-peak (Fig. 5A,B). This points to normal responsiveness of the patient platelets to the stimulating effects of ADP and SFLLRN under coagulant conditions. The patients with stroke all used aspirin but, as shown before, ${ }^{19}$ thrombin generation curves are only little affected by aspirin treatment. 
Table 1. Thrombogram characteristics of PRP from healthy subjects and patients with stroke or diabetes mellitus.

\begin{tabular}{llll}
\hline Subject $(n)$ & $\begin{array}{l}\text { Thrombin peak } \\
(\mathrm{nM})\end{array}$ & $\begin{array}{l}\text { Time to peak } \\
(\mathrm{min})\end{array}$ & $\begin{array}{l}\text { ETP } \\
(\mathrm{nM} \times \mathrm{min})\end{array}$ \\
\hline Healthy controls (11) & $78.2 \pm 23$ & $31.2 \pm 7.9$ & $1667 \pm 331$ \\
Young stroke patients (11) & $92.4 \pm 30$ & $25.9 \pm 7.9$ & $1726 \pm 430$ \\
Other stroke patients (9) & $119 \pm 22^{*}$ & $26.5 \pm 6.0$ & $1868 \pm 377$ \\
Diabetic patients (12) & $104 \pm 25^{*}$ & $30.8 \pm 7.2$ & $1960 \pm 293^{*}$ \\
\hline
\end{tabular}

Thrombin generation was measured in normalised PRP $\left(150 \times 10^{9}\right.$ platelets/L, f.c. $)$, with post-hoc calibration. Shown are mean values \pm SD of thrombin peak-height, time-to-peak and area-under-thecurve (ETP). All stroke patients had aspirin medication, other subjects were free from medication. ${ }^{*} \mathrm{p} \leq 0.05$ vs. healthy controls.
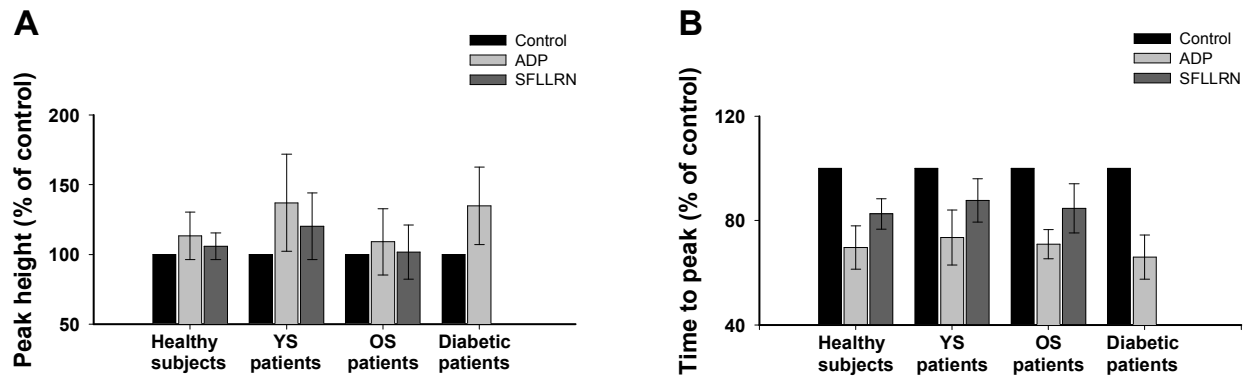

Figure 5. Potentiation of thrombin generation by ADP and SFLLRN in PRP from healthy subjects and patients. PRP was obtained from healthy subjects, young stroke (YS) patients, stroke patients of older age (OS), and type-II diabetic patients (see Table 1). Platelets in PRP were activated for 10 min with $20 \mu \mathrm{M}$ ADP or $15 \mu \mathrm{M}$ SFLLRN, and then triggered with tissue factor/CaCl for measurement of thrombin generation. Thrombogram data (post-hoc calibration) are given of $(A)$ thrombin peak height and (B) time-to-peak relative to control condition without (ant)agonist (means $\pm S D, n=8-12$ ).

\section{Clopidogrel treatment variably abolishes $A D P / P 2 Y_{12}$ effects on thrombin generation}

Since the ADP-induced effect on thrombin generation completely relies on $\mathrm{P} 2 \mathrm{Y}_{12}$ activity, this effect could be used to monitor the efficacy of medication with clopidogrel, which gives rise to irreversible blockade of this receptor. In PRP from nine older patients with stroke, we were able to investigate this before and after 14 days of clopidogrel medication ( $75 \mathrm{mg} /$ day). In thrombin generation experiments, two sets of conditions were compared: first, PRP was activated with ADP before start of thrombin generation, to achieve maximal $\mathrm{P} 2 \mathrm{Y}_{12}$ activity; second, the PRP was pretreated with a high dose of ARC $(30 \mu \mathrm{M})$ before activation, sufficient to suppress all ADP-induced effects. The percentage effect of $A R-C$ on thrombin peak height was taken as a measure of the $P 2 Y_{12}$ 
A
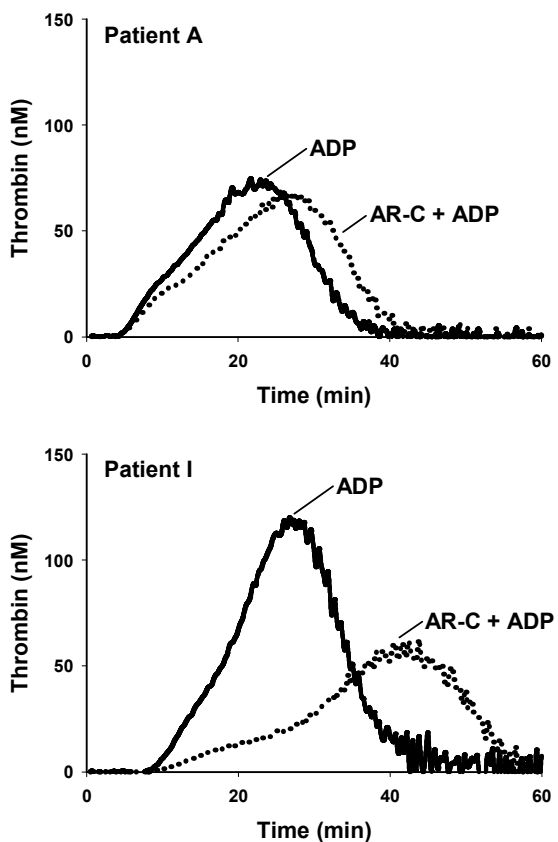

B

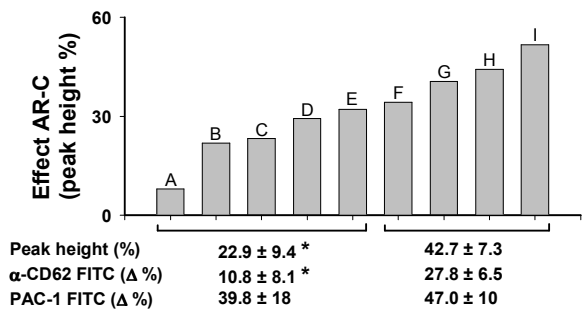

C

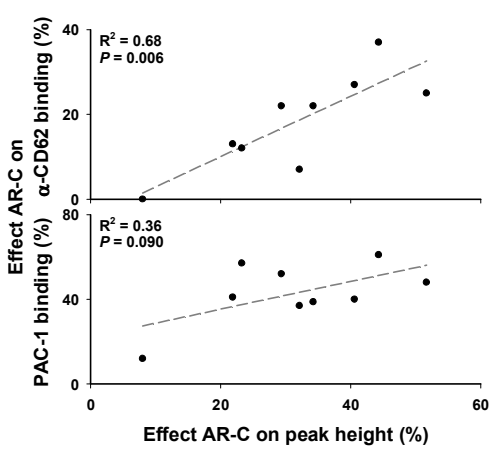

Figure 6. Variable $P 2 Y_{12}$-mediated thrombin generation and platelet activation after clopidogrel intervention. Blood was drawn from 9 stroke patients of older age after 14 days of clopidogrel medication. To measure P2 ${ }_{12}$-mediated activity, PRP was stimulated with ADP $(20 \mu \mathrm{M})$ in the presence or absence of AR-C $(30 \mu \mathrm{M})$. For the indicated platelet responses, percentage effects of AR-C were taken as a measure of relative $P 2 Y_{12}$ activity. (A) Typical thrombin generation curves for patients with a high (patient $A$ ) or low (patient $I$ ) remaining $\mathrm{P}_{2} \mathrm{Y}_{12}$ response after clopidogrel intervention. Thrombin generation in PRP was triggered with tissue factor/ $\mathrm{CaCl}_{2}$. (B) Variable contribution of $\mathrm{P}_{2} \mathrm{Y}_{12}$ to thrombin generation; data from all 9 patients are expressed as percentage AR-C effects on thrombin peak height. Number under bars indicate AR-C effects on thrombin peak height, P-selectin exposure (\% of platelets binding to anti-CD62 FITC) and on integrin $\alpha$ llb $\beta 3$ activation (\% of platelets binding to PAC-1 FITC). Exposure of P-selectin and integrin activation were measured by flow cytometry in diluted PRP, pre-activated with ADP $(20 \mu \mathrm{M})$ in the presence or absence of AR-C $(30 \mu \mathrm{M})$. (C) Correlations between thrombin generation and flow cytometric measurements.

activity in thrombin generation. For all 9 patients, this $\mathrm{P} 2 \mathrm{Y}_{12}$ activity diminished after clopidogrel intake from $41 \pm 13$ to $32 \pm 13 \%$ (mean $\pm S D, n=9, P=0.057$ ). As a comparison, using flow cytometry, ADP-induced effects were determined on platelet activation markers in the presence and absence of AR-C. The P2Y 12 activity (i.e. percentage effect of AR-C) in ADP-induced P-selectin exposure significantly reduced from $44 \pm 13$ to $18 \pm 11 \%$ after clopidogrel treatment. Similarly, the $P 2 Y_{12}$ activity in ADP-induced activation of $\alpha \mathrm{llb} \beta 3$ (using the PAC-1 antibody) reduced from $60 \pm 14 \%$ to $43 \pm 14 \%$, the remaining part being attributable to $\mathrm{P} 2 \mathrm{Y}_{1}$ action.

Most clearly after clopidogrel intake, there was considerable variation in $\mathrm{P}_{2} \mathrm{Y}_{12}$ activity between patients (Fig. 6A). The PRP from one subjects (patient A) hardly responded to the presence of $A D P$ or $A R-C$, while the PRP from another subject (patient 
I) showed considerable responses to these compounds. Arbitrarily, the patients were divided into two about equal groups; one group of patients with a low $\mathrm{P}_{2} \mathrm{Y}_{12}$ activity after clopidogrel ('high' responders) and the other group of patients with high residual $\mathrm{P}_{2} \mathrm{Y}_{12}$ activity ('low' responders) (Fig. 6B). Flow cytometric measurements confirmed that these groups differed in $\mathrm{P}_{2} \mathrm{Y}_{12}$ activity with residual values of P-selectin exposure of $29 \pm 7 \%$ and $11 \pm 8 \%$, respectively. There was no such a difference in $P 2 Y_{12}$-mediated $\alpha$ llb $\beta 3$ activation. Notably, comparison of all individual patient data indicated a good correlation of $\mathrm{P}_{2} \mathrm{Y}_{12}$ activity in thrombin generation with $\mathrm{P}_{2} \mathrm{Y}_{12}$ activity in P-selectin exposure (Fig. $6 \mathrm{C})$. This suggests that either of these parameters can be a suitable marker of resistance to clopidogrel intervention. Only in the high-responding group, but not in the other group, clopidogrel intake appeared to reduce the $\mathrm{P} 2 \mathrm{Y}_{12}$ activity on thrombin generation from $35 \pm 3.3$ pre-treatment to $23 \pm 9.4 \%$ post-treatment $(P=0.041)$. Similarly, $\mathrm{P} 2 \mathrm{Y}_{12}$-dependent $\mathrm{P}$-selectin exposure was reduced in this group from $43 \pm 16$ to $11 \pm 8.1 \%$ $(P=0.005)$ and $\alpha$ llb $\beta 3$ activation from $62 \pm 16$ to $40 \pm 18 \% \quad(P=0.001)$. Together, the thrombin generation measurements point to incomplete, but highly variable effects of clopidogrel intake on $\mathrm{P}_{2} \mathrm{Y}_{12}$ receptor function in these patients.

\section{Discussion}

The present data show that platelet stimulation with ADP or SFLLRN results in a considerable stimulation of thrombin generation and, thus, coagulant activity in a $\mathrm{P}_{2} \mathrm{Y}_{12^{-}}$ dependent manner. Complete abolition of the ADP-mediated effects is obtained with the specific $\mathrm{P}_{2} \mathrm{Y}_{12}$ antagonist AR-C (from $1 \mu \mathrm{M}$ ), but not with the $\mathrm{P} 2 \mathrm{Y}_{1}$ blocker MRS, whereas the latter compound affects platelet shape change under these coagulant conditions, proving that the $\mathrm{P}_{2} \mathrm{Y}_{1}$ receptor is still signaling. Typically, MRS, when applied at concentrations around its $K_{d}$ value for $P_{2} Y_{1}\left(10^{-5} \mathrm{M}\right)$, results in a small, dosedependent increase rather than a decrease in thrombin generation, indicating that $\mathrm{P}_{2} \mathrm{Y}_{1}$ is not positively involved in procoagulant activity. We also find that $\mathrm{P}_{2} \mathrm{Y}_{12}$ stimulation under conditions of thrombin generation leads to increased exposure of PS at the platelet outer surface, and that the PS-chelating annexin A5 completely abolishes thrombin generation with ADP. Thus, ADP is not only a proaggregatory agonist, but is also, exclusively via $\mathrm{P} 2 \mathrm{Y}_{12}$, a potent enhancer of the platelet procoagulant response via PS exposure.

The results of $\mathrm{Ca}^{2+}$ measurements provide a first biochemical explanation for the procoagulant ADP effect. In spite of the fact that thrombin causes a high $\mathrm{Ca}^{2+}$ response in platelets, co-stimulation with ADP (via $\mathrm{P}_{2} \mathrm{Y}_{12}$ ) further increases and prolongs this thrombin-induced response. It has been proposed that $P 2 Y_{12}$ stimulation increases $\mathrm{Ca}^{2+}$ signal generation by lowering cyclic-AMP, e.g. in platelets treated with prostaglandins. ${ }^{33,34}$ However, the potentiating effects of ADP on thrombin-induced $\mathrm{Ca}^{2+}$ signaling and PS exposure most probably involve a different pathway, as platelet treatment with adrenaline, which maximally lowers cyclic-AMP, fails to abolish the ADP effect. The ADP effects are also likely to be independent of platelet aggregation, because inhibitors of $\alpha$ llb $\beta 3$ or Src kinases do not influence the $\mathrm{Ca}^{2+}$ responses with 
ADP/thrombin (data not shown). On the other hand, we found that PI3-K inhibition with wortmannin partly inhibited the ADP-enhanced $\mathrm{Ca}^{2+}$ response and thrombin generation. This partially agrees with a recent report that $\mathrm{P}_{2} \mathrm{Y}_{12} / \mathrm{PI}-3 \mathrm{~K}$ signaling is involved in the $\mathrm{Ca}^{2+}$ response evoked by ADP alone. ${ }^{34}$ However, these authors also mentioned a modulatory effect of Src kinases, which we could not confirm under the present conditions with added thrombin.

To detect a possibly increased contribution of $\mathrm{P}_{2} \mathrm{Y}_{12}$ in thrombin generation, ADPand SFLLRN-induced effects were evaluated in PRP from patients at thrombotic risk, i.e. patients with stroke or type-II diabetes mellitus. There was intersubject variation in all patient groups, but the stimulating effects of ADP or SFLLRN on thrombin generation were nevertheless comparable to those in control PRP from healthy subjects.

In blood from patients with stroke, ADP/P2 $Y_{12}$-medated thrombin generation was measured after a period of clopidogrel intake. In most of the patients, this intervention appeared to result in only partial blockade of the ADP/P2Y 12 effects on thrombin generation. In fact, in only 1 out of 9 patients clopidogrel suppressed thrombin generation to a similar degree as $A R-C$. This variable responsiveness to clopidogrel was confirmed by parallel measurements of ADP/P2 $\mathrm{Y}_{12}$-mediated P-selectin exposure, which is a $\mathrm{Ca}^{2+}$-dependent platelet response. These findings are remarkably consistent with a recent report, showing a fairly incomplete responsiveness to clopidogrel (in comparison to AR-C added in vitro) in patients with ischemic cardiovascular diseases, using an indirect assay of $\mathrm{P} 2 \mathrm{Y}_{12} / \mathrm{Gi}$-regulated VASP phosphorylation. ${ }^{35}$ In that paper, it was concluded that one-third of patients is not protected by the therapy, which also fits with our data. The present findings thus underline the notion in several clinical studies that resistance to clopidogrel (resulting in variable platelet inhibition) is a common phenomenon. ${ }^{36,37}$ A number of explanations for clopidogrel resistance have been put forward in the literature, including possible interaction of clopidogrel with statins. ${ }^{38} \mathrm{We}$ can confirm the partial efficacy of clopidogrel treatment and, furthermore, note that the thrombogram method is useful for measuring this.

\section{Acknowledgements}

We acknowledge W. Beks for initial experimentation. This work was supported in part by Unilever Research (Vlaardingen, The Netherlands). 


\section{References}

1. Béguin S, Kumar R. Thrombin, fibrin and platelets, a resonance loop in which von Willebrand factor is a necessary link. Thromb Haemost. 1997;78:590-594.

2. Monroe DM, Hoffman M, Roberts HR. Platelets and thrombin generation. Arterioscler Thromb Vasc Biol. 2002;22:1381-1389.

3. Heemskerk JW, Bevers EM, Lindhout T. Platelet activation and blood coagulation. Thromb Haemost. 2002;88:186-193.

4. Bevers EM, Comfurius P, van Rijn JL, Hemker HC, Zwaal RF. Generation of prothrombinconverting activity and the exposure of phosphatidylserine at the outer surface of platelets. Eur J Biochem. 1982;122:429-436.

5. Coughlin SR. Thrombin signaling and protease-activated receptors. Nature. 2000;407:258264.

6. Heemskerk JW, Feijge MA, Henneman L, Rosing J, Hemker HC. The $\mathrm{Ca}^{2+}$-mobilizing potency of $\alpha$-thrombin and thrombin-receptor-activating peptide on human platelets. Eur J Biochem. 1997;249:547-555.

7. Andersen H, Greenberg DL, Fujikawa K, Xu WF, Chung DW, Davie EW. Protease-activated receptor 1 is the primary mediator of thrombin-stimulated platelet procoagulant activity. Proc Natl Acad Sci USA. 1999;96:11189-11193.

8. Gachet C, Hechler B, Léon C, Vial C, Leray C, Ohlmann P, Cazenave JP. Activation of ADP receptors and platelet function. Thromb Haemost. 1997;78:271-275.

9. Kunapuli SP, Dorsam RT, Kim S, Quinton TM. Platelet purinergic receptors. Curr Opin Pharmacol. 2003;3:175-180.

10. Jin J, Kunapuli SP. Coactivation of two different $G$ protein-coupled receptors is essential for ADP-induced platelet aggregation. Proc Natl Acad Sci USA. 1998;95:8070-8074.

11. Hollopeter G, Jantzen HM, Vincent D, Li G, England L, Ramakrishnan V, Yang RB, Nurden P, Nurden A, Julius D, Conley PB. Identification of the platelet ADP receptor targeted by antithrombotic drugs. Nature. 2001;409:202-208.

12. Remijn JA, Wu YP, Heninga EH, IJsseldijk MJW, van Willigen G, de Groot PG, Sixma JJ, Nurden AT, Nurden P. Role of ADP receptor P2Y 12 in platelet adhesion and thrombus formation in flowing blood. Arterioscler Thromb Vasc Biol. 2002;22:686-691.

13. Siljander PR, Munnix IC, Smethurst PA, Deckmyn H, Lindhout T, Ouwehand WH, Farndale RW, Heemskerk JW. Platelet receptor interplay regulates collagen-induced thrombus formation in flowing human blood. Blood. 2004;103:1333-1341.

14. Keularts IM, van Gorp RM, Feijge MA, Vuist WM, Heemskerk JW. $\alpha 2 A$-adrenergic receptor stimulation potentiates calcium release in platelets by modulating cAMP levels. J Biol Chem. 2000;275:1763-1772.

15. Hirsch E, Bosco O, Tropel P, Laffargue M, Calvez R, Altruda F, Wymann M, Montrucchio G. Resistance to thromboembolism in PI3K $\gamma$-deficient mice. FASEB J. 2001;15:2019-2021.

16. Kauffenstein G, Bergmeier W, Eckly A, Ohlmann P, Leon C, Cazanave JP, Nieswandt B, Gachet $C$. The $P 2 Y_{12}$ receptor induces platelet aggregation through weak activation of the

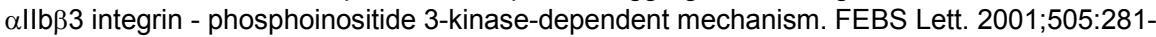
290.

17. Weiss HJ, Lages B. Platelet prothrombinase activity and intracellular calcium responses in patients with storage pool deficiency, glycoprotein IIb/llla deficiency, or impaired platelet coagulant activity--a comparison with Scott syndrome. Blood. 1997;89:1599-1611.

18. Léon C, Ravanat C, Freund M, Cazenave JP, Gachet C. Differential involvement of the P2Y, and $\mathrm{P}_{2} \mathrm{Y}_{12}$ receptors in platelet procoagulant activity. Arterioscler Thromb Vasc Biol. 2003;23:1941-1947.

19. Vanschoonbeek K, Feijge MA, van Kampen RJ, Kenis H, Hemker HC, Giesen PL, Heemskerk JW. Initiating and potentiating role of platelets in tissue factor-induced thrombin generation in the presence of plasma: subject-dependent variation in thrombogram characteristics. J Thromb Haemost. 2004;2:476-484. 
20. Dorsam RT, Tuluc M, Kunapuli SP. Role of protease-activated and ADP receptor subtypes in thrombin generation on human platelets. J Thromb Haemost. 2004;2:804-812.

21. Thiagarajan P, Tait JF. Collagen-induced exposure of anionic phospholipid in platelets and platelet-derived microparticles. J Biol Chem. 1991;266:24302-24307.

22. Savi P, Pereillo JM, Uzabiaga MF, Combalbert J, Picard C, Maffrand JP, Pascal M, Herbert $\mathrm{JM}$. Identification and biological activity of the active metabolite of clopidogrel. Thromb Haemost. 2000;84:891-896.

23. Cattaneo $\mathrm{M}$. The platelet $\mathrm{P} 2 \mathrm{Y}$ receptors as targets for new antithrombotic drugs. J Thromb Haemost. 2003;1:1133-1135.

24. Conley PB, Delaney SM. Scientific and therapeutic insights into the role of the platelet P2Y 12 receptor in thrombosis. Curr Opin Hematol. 2003;10:333-338.

25. Vanschoonbeek K, Feijge MA, Keuren JF, Hemker HC, Lodder JJ, Hamulyak K, van Pampus EC, Heemskerk JW. Thrombin-induced hyperactivity of platelets of young stroke patients: involvement of thrombin receptors in the subject-dependent variability in $\mathrm{Ca}^{2+}$ signal generation. Thromb Haemost. 2002;88:931-937.

26. Carr ME. Diabetes mellitus: a hypercoagulable state. J Diabetes Complications. 2001;15:4454.

27. Lau WC, Gurbel PA, Watkins PB, Neer CJ, Hopp AS, Carville DG, Guyer KE, Tait AR, Bates ER. Contribution of hepatic cytochrome P450 3A4 metabolic activity to the phenomenon of clopidogrel resistance. Circulation. 2004;109:166-171.

28. Hemker HC, Giesen PL, Ramjee M, Wagenvoord R, Béguin S. The thrombogram: monitoring thrombin generation in platelet-rich plasma. Thromb Haemost. 2000;83:589-591.

29. Hemker HC, Giesen P, Al Dieri R, Regnault V, de Smedt E, Wagenvoord R, Lecompte T, Béguin S. Calibrated automated thrombin generation measurement in clotting plasma. Pathophysiol Haemost Thromb. 2003;33:4-15.

30. Feijge MA, van Pampus EC, Lacabaratz-Porret C, Hamulyak K, Lévy-Toledano S, Enouf J, Heemskerk JW. Inter-individual variability in $\mathrm{Ca}^{2+}$ signaling in platelets from healthy volunteers: effects of aspirin and relationship with expression of endomembrane $\mathrm{Ca}^{2+}$ ATPases. Br J Haematol. 1998;102:850-859.

31. Curvers J, van Pampus EC, Feijge MA, Rombout-Sestrienkova E, Giesen PL, Heemskerk JW. Decreased responsiveness and development of activation markers of PLTs stored in plasma. Transfusion. 2004;44:49-58.

32. Sage SO, Yamoah EH, Heemskerk JW. The roles of $P 2 X_{1}$ and $P 2 T_{A C}$ receptors in ADPevoked calcium signaling in human platelets. Cell Calcium. 2000;28:119-126.

33. Fox SC, Behan MW, Heptinstall S. Inhibition of ADP-induced intracellular $\mathrm{Ca}^{2+}$ responses and platelet aggregation by the $P 2 Y_{12}$ receptor antagonists AR-C69931MX and clopidogrel is enhanced by prostaglandin $E_{1}$. Cell Calcium. 2004;35:39-46.

34. Hardy AR, Jones ML, Mundell SJ, Poole AW. Reciprocal cross-talk between P2Y 1 and P2Y ${ }_{12}$ receptors at the level of calcium signaling in human platelets. Blood. 2004;104:1745-1752.

35. Aleil B, Ravanat C, Cazenave JP, Rochoux G, Heitz A, Gachet C. Flow cytometric analysis of intraplatelet VASP phosphorylation for the detection of clopidogrel resistance in patients with ischemic cardiovascular diseases. J Thromb Haemost. 2005;3:85-92.

36. Gurbel PA, Bliden KP. Durability of platelet inhibition by clopidogrel. Am J Cardiol. 2003;91:1123-1125.

37. Muller I, Besta F, Schulz C, Massberg S, Schonig A, Gawaz M. Prevalence of clopidogrel non-responders among patients with stable angina pectoris scheduled for elective coronary stent placement. Thromb Haemost. 2003;89:783-787.

38. Nawarskas JJ. Clopidogrel-statin interaction. Cardiol Rev. 2004;12:236-239. 


\section{4}

\section{Dual $\mathrm{P}_{2} \mathrm{Y}_{12}$ receptor signaling in thrombin-stimulated platelets.}

Involvement of phosphoinositide 3-kinase $\beta$ but not $\gamma$ isoform in $\mathrm{Ca}^{2+}$ mobilization and procoagulant activity

Paola E.J. van der Meijden, Simone M. Schoenwaelder, Marion A.H. Feijge, Judith M.E.M. Cosemans, Imke C.A. Munnix, Reinhard Wetzker, Regine Heller, Shaun P. Jackson and Johan W.M. Heemskerk

FEBS J 2008; 275: 371-385

Reprinted with permission 


\section{Abstract}

During thrombus formation, thrombin, which is abundantly present at sites of vascular injury, activates platelets in part via autocrine produced ADP. We investigated by which signaling pathways thrombin and ADP in synergy induced platelet $\mathrm{Ca}^{2+}$ elevation and procoagulant activity, and we monitored the consequences for the coagulation process. Even at high thrombin concentration, autocrine and added ADP enhanced and prolonged $\mathrm{Ca}^{2+}$ depletion from internal stores via stimulation of the $\mathrm{P} 2 \mathrm{Y}_{12}$ receptors. This $\mathrm{P} 2 \mathrm{Y}_{12-}$ dependent effect was mediated via two distinct signaling pathways. The first is enhanced $\mathrm{Ca}^{2+}$ mobilization by the inositol 1,4,5-trisphosphate receptors due to inhibition of protein kinase A. The second pathway concerns prolonged activation of phosphoinositide 3kinase $(\mathrm{PI} 3-\mathrm{K})$ and phospholipase $\mathrm{C}$. Experiments with $\mathrm{PI}-\mathrm{K}$ isoform-selective inhibitors and $\mathrm{p} 110 \gamma$ deficient platelets demonstrated that the $\mathrm{PI} 3-\mathrm{K} \beta$ and not the $\mathrm{PI} 3-\mathrm{K} \gamma$ isoform is responsible for the prolonged $\mathrm{Ca}^{2+}$ response and for the subsequent increases in procoagulant activity and coagulation. Taken together, these results demonstrate a dual $\mathrm{P}_{2} \mathrm{Y}_{12}$-dependent signaling mechanism, which increases the platelet-activating effect of thrombin by prolongation of $\mathrm{Ca}^{2+}$ elevation and, thereby, facilitating the coagulation process.

\section{Introduction}

Platelets are activated at sites of vascular injury, and then clump together to form a vasoocclusive thrombus. Platelet activation is usually triggered by the exposure of a thrombogenic surface like collagen, and continues by the availability of soluble agonists that are derived from the injured vessel wall or the activated platelets themselves. One of the most potent, soluble platelet-activating agents is thrombin. Intravital imaging studies of thrombus formation in damaged mouse arteries indicate that thrombin is rapidly formed at thrombotic sites via the tissue factor/factor VIla pathway of coagulation. ${ }^{1}$ This is confirmed by inhibitory studies in various experimental models, showing that thrombin generation plays a key, driving role in the thrombotic process. ${ }^{2-4}$ Once thrombin is formed, it will inevitably interact with and activate all nearby platelets. ${ }^{5}$

Thrombin stimulates platelets mostly or only via the protease-activated receptors, PAR1/4 on human and PAR3/4 on mouse platelets, which all signal through the $G$ proteins, $\mathrm{Gq}$ and $\mathrm{G} 12 / 13$. $^{6,7}$ Thrombin evokes multiple responses, such as shape change, $\mathrm{Ca}^{2+}$ mobilization, secretion, integrin $\alpha$ llb $\beta 3$ activation, and assembly of a platelet aggregate. ${ }^{8}$ Furthermore, thrombin enhances the development of platelet procoagulant activity. ${ }^{9}$ Particularly, in combination with collagen, it causes a prolonged elevation in cytosolic $\left[\mathrm{Ca}^{2+}\right]$, which leads to the exposure of phosphatidylserine (PS) at the platelet outer membrane. This provides a procoagulant surface, upon which coagulation factors assemble to produce factor $\mathrm{Xa}$ and thrombin. Hence, the generation of initial traces of thrombin via the tissue factor/factor VII pathway leads to a strong positive feedback loop, where thrombin activates platelets, platelets become procoagulant, and more thrombin is formed at the surface of these platelets. ${ }^{9,10}$ 
Although ADP is considered to be a weak agonist, studies with human and mouse platelets have indicated that it does play an important role in thrombus formation. ${ }^{11,12}$ Being secreted from platelets in large amounts, ADP functions as an autocrine agonist sustaining many activation processes. Secreted ADP binds to the $P 2 Y_{1}$ and $P 2 Y_{12}$ purinergic receptors, and triggers shape change, $\mathrm{Ca}^{2+}$ mobilization and platelet aggregation. ${ }^{13-15}$ The $\mathrm{P}_{2} \mathrm{Y}_{1}$ receptors are linked to $\mathrm{Gq}$, but they evoke much weaker responses than thrombin receptor activation. ${ }^{16}$ The result is limited activation of phospholipase $\mathrm{C}$, leading to formation of inositol 1,4,5-trisphosphate (InsP3) and Ins $\mathrm{P}_{3}$ receptor-mediated elevation in $\left[\mathrm{Ca}^{2+}\right]_{i}$. The $\mathrm{P}_{2} \mathrm{Y}_{12}$ receptors are coupled to $\mathrm{Gi}$ and signal in a different way. Both in human and mouse platelets, $P 2 Y_{12}$ induces Gi-dependent inhibition of adenylyl cyclase and consequent down-regulation of CAMP. ${ }^{13,17}$ In this way, (autocrine produced) ADP can relieve the platelet-inactivating effect of cAMP and its effector, protein kinase $A(P K A) .{ }^{14}$ Also downstream of $\mathrm{Gi}, \mathrm{P}_{2} \mathrm{Y}_{12}$ receptors stimulate the less well understood phosphoinositide 3-kinase ( $\mathrm{PI3}-\mathrm{K}$ ) pathway, which leads to $\alpha$ llb $\beta 3$ integrin activation and platelet aggregation. ${ }^{18} \mathrm{We}$ and others have shown that both the $\mathrm{PI} 3-\mathrm{K} \beta$ and $\mathrm{PI}-\mathrm{K} \gamma$ isoforms contribute to the $\mathrm{P}_{2} \mathrm{Y}_{12}$-mediated stabilization of platelet aggregates under static and shear conditions. ${ }^{19-21}$

Recently, it was established that $\mathrm{P}_{2} \mathrm{Y}_{12}$ signaling is implicated in the stimulating effect of thrombin on PS exposure and procoagulant activity of platelets. ${ }^{5,22,23} \mathrm{We}$ hence hypothesized that the thrombin and $\mathrm{P}_{2} \mathrm{Y}_{12}$ receptors signal in a synergistic way towards this platelet response. Since elevation in $\left[\mathrm{Ca}^{2+}\right]_{i}$ is a key feature in PS exposure, we started to investigate how thrombin and ADP receptor stimulation co-operate to induce $\mathrm{Ca}^{2+}$ mobilization and to provoke platelet procoagulant activity. We found that autocrine released $A D P$ via $\mathrm{P}_{2} \mathrm{Y}_{12}$ causes a marked prolongation of the $\left[\mathrm{Ca}^{2+}\right]_{i}$ elevation even with high doses of thrombin. Subsequently, using platelets that were co-stimulated with fixed concentrations of thrombin and ADP we unraveled the signaling mechanism underlying this $P 2 Y_{12}$ effect. The results point to a dual regulatory pathway evoked by $P 2 Y_{12}$. It involves increased $\operatorname{InsP}_{3}$ receptor function due to inactivation of the cAMP/PKA route. This effect is accompanied by prolongation of thrombin/ADP-evoked phospholipase $C$ activity and $\mathrm{Ca}^{2+}$ mobilization in a way controlled by PI3-K $\beta$.

\section{Materials and methods}

\section{Animals}

Animal experiments were approved by the local animal experimental committees. Wildtype control $\left(\mathrm{p} 110 \gamma^{+/+}\right)$and PI3-K $\gamma$ deficient $\left(\mathrm{p} 110 \gamma^{-/-}\right)$mice, with identical genetic backgrounds, were generated as described. ${ }^{21,41}$

\section{Materials}

Human $\alpha$-thrombin (3270 NIH units/mg, 12,750 units $/ \mathrm{mL}, 1.12 \mu \mathrm{M}$ ) was obtained from Enzyme Research Laboratories. Fura-2, Fura red and Oregon green (OG)-BAPTA 
acetoxymethyl esters (AM) as well as non-esterified Fluo-3 were from Molecular Probes; ultra-pure calcium-free water was from Baker Analytical. Cangrelor (AR-C69931MX, ARC) was kindly provided by The Medicines Company. Fluorescent thrombin substrate, ZGly-Gly-Arg aminomethyl coumarin (Z-GGR-AMC) was from Bachem; recombinant human tissue factor from Dade Behring; and human thrombin calibrator from Synapse. InsP $_{3}$ was from Alexis Biochemicals; tirofiban from Merck, Sharp and Dohme; Akt inhibitor and LY294002 from Calbiochem. ET-18-OCH3, manoalide, U73122 and U73343 came from Biomol. PI3-K isoform-specific inhibitors were kind gifts of Baker Heart Institute, i.e. TGX221, selective for the PI3-K $\beta$ isoform ( $p 110 \beta$ ), and AS252424, selective for PI3-K $\gamma$ (p110 $\gamma$ ), both synthesized as described. ${ }^{21,42}$ Fluorescent-labeled annexin A5 was obtained from Nexins Research. Other materials were from Sigma.

\section{Platelet preparation and isolation}

Blood was taken from healthy volunteers, who gave full informed consent; subjects were free from medication for at least two weeks. Blood was collected into 1/6 volume of acidcitrate glucose solution (ACD, $80 \mathrm{mM}$ trisodium citrate, $52 \mathrm{mM}$ citric acid and $180 \mathrm{mM}$ glucose). Human platelet-rich plasma (PRP) was obtained by 15 -min centrifuging at 240 g. Blood from mice was collected and handled as described. ${ }^{3}$ Murine PRP was prepared by centrifuging blood at $280 \mathrm{~g}$ for $3 \mathrm{~min}$, and centrifuging the upper phase once more at $625 \mathrm{~g}$ for $10 \mathrm{~s}$. Platelet counts were determined with a thrombocounter (Coulter Electronics).

Platelet shape change was measured in PRP or washed platelets by turbidometry in the presence of tirofiban to prevent aggregation. Shape change evoked by up to $20 \mu \mathrm{M}$ ADP was not significantly $(<10 \%)$ influenced by $A R-C$ in the range of $1-30 \mu \mathrm{M}$, indicating that $A R-C$ did not interfere with the $P 2 Y_{1}$-dependent response.

\section{Measurements of cytosolic $\mathrm{Ca}^{2+}$ in intact and permeabilized platelets}

To measure $\left[\mathrm{Ca}^{2+}\right]_{i}$ in intact human platelets, PRP was incubated with the fluorescent probe Fura-2 AM $(2.5 \mu \mathrm{M})$ at $37^{\circ} \mathrm{C}$ for $45 \mathrm{~min}$. After addition of $1 / 15$ volume of $A C D$ and apyrase $(0.1 \mathrm{U} / \mathrm{mL}$ ADPase), platelets were centrifuged from plasma, washed and resuspended in Hepes buffer pH 7.45 [10 mM Hepes, $136 \mathrm{mM} \mathrm{NaCl}, 2.7 \mathrm{mM} \mathrm{KCl}, 2 \mathrm{mM}$ $\mathrm{MgCl}_{2}, 0.1 \%$ glucose and $0.1 \%$ bovine serum albumin (BSA)], as described. ${ }^{43}$ Washed Fura-2-loaded platelets were diluted in Hepes buffer $\mathrm{pH} 7.45$ to $1 \times 10^{8}$ platelets $/ \mathrm{mL}$. Changes in cytosolic $\left[\mathrm{Ca}^{2+}\right]_{\mathrm{i}}$ were measured by ratio fluorometry under stirring; $\left[\mathrm{Ca}^{2+}\right]_{\mathrm{i}}$ time integrals were measured to quantify prolonged $\mathrm{Ca}^{2+}$ responses. ${ }^{44}$

Changes in $\left[\mathrm{Ca}^{2+}\right]_{\mathrm{i}}$ in mouse platelets were measured as published. ${ }^{45}$ Briefly, the washed platelets $\left(5.0 \times 10^{8} / \mathrm{mL}\right)$ were incubated with OG-BAPTA AM $(1 \mu \mathrm{M})$ and Fura red AM $(1.25 \mu \mathrm{M})$ for $30 \mathrm{~min}$ at $37^{\circ} \mathrm{C}$, and subsequently resuspended at $2.5 \times 10^{8} / \mathrm{mL}$ in Hepes buffer $\mathrm{pH} 7.45$, containing BSA $(5 \mathrm{mg} / \mathrm{mL}), \mathrm{CaCl}_{2}(1 \mathrm{mM})$, apyrase $(0.02 \mathrm{U} / \mathrm{mL})$ and probenecid $(1.75 \mathrm{mM})$. Platelets were stimulated by addition of thrombin $(4 \mathrm{nM})$ and/or ADP $(20 \mu \mathrm{M})$, and ratiometric changes in $\left[\mathrm{Ca}^{2+}\right]_{i}$ were then determined. ${ }^{45}$ 
In permeabilized human platelets, InsP $\mathrm{P}_{3}$-induced $\mathrm{Ca}^{2+}$ mobilization from internal stores was measured, using an earlier established procedure. ${ }^{27}$ Washed human platelets were resuspended in $\mathrm{Ca}^{2+}$-free Hepes buffer $\mathrm{pH} 7.45$ containing $0.1 \mathrm{mM}$ EGTA $\left(1.5 \times 10^{9}\right.$ platelets $/ \mathrm{mL}$ ). The cells were diluted in ATP-regenerating medium, preincubated for 15 min with (ant)agonist, stimulated with $A D P$, and then permeabilized with $15 \mu \mathrm{g} / \mathrm{mL}$ saponin in the presence of $1 \mu \mathrm{M}$ free Fluo-3. After $10 \mathrm{~min}$ of stirring, free $\left[\mathrm{Ca}^{2+}\right]$ was adjusted to $300 \mathrm{nM}$ with a $\mathrm{CaCl}_{2}$ stock solution, after which $\operatorname{InsP}_{3}$ was added. Fluorescence intensities were continuously recorded at $488 \mathrm{~nm}$ excitation and $526 \mathrm{~nm}$ emission wavelengths using an SLM-Aminco DMX-1100 spectrofluorometer. Calibrations were performed by adding excess amounts of $\mathrm{CaCl}_{2}$ or EGTA/Tris; levels of $\left[\mathrm{Ca}^{2+}\right.$ ] were calculated from the binding equation of Fluo-3 for $\mathrm{Ca}^{2+} \cdot{ }^{27}$ Ultra-pure calcium-free water was used for preparation of all buffers and (ant)agonists.

\section{Measurement of cytosolic cAMP and Ins $\mathrm{P}_{3}$}

Intracellular levels of cAMP and $\mathrm{InSP}_{3}$ in resting and activated platelets were measured as described. ${ }^{27}$ Basal concentrations were $2.59 \pm 0.17$ and $0.96 \pm 0.08 \mathrm{pmol} / 10^{8}$ platelets $(n=6)$, respectively.

\section{Measurement of SERCA activity}

Decay constants of $\left[\mathrm{Ca}^{2+}\right]_{i}$ decreases following peak values were determined by monoexponential fitting of 2-s data points. SERCA activity in saponin-permeabilized platelets was determined by measuring fluorescence accumulation due to cleavage of the $\mathrm{Ca}^{2+}$. ATPase substrate, 3-O-methylfluorescein phosphate. ${ }^{46}$ SERCA activity represented the ATP- and thapsigargin-sensitive phosphatase activity.

\section{Measurement of Akt activation}

Akt activation was measured by western blot analysis, using a phosphoserine-473 Akt polyclonal antibody (Biosource International) to detect active Akt kinase, as well as a separate Akt polyclonal antibody (Cell Signaling Technology) to determine total Akt, as described. ${ }^{19}$

\section{Thrombin generation}

For thrombin generation measurements, human or mouse blood was collected in $1 / 10$ volume of $129 \mathrm{mM}$ trisodium citrate. Isolated PRP was centrifuged twice at $2700 \mathrm{~g}$ for 10 min to prepare platelet-poor plasma. The PRP was diluted to the desired platelet count with autologous PPP.

Normalized PRP $\left(1.5 \times 10^{8}\right.$ platelets $\left./ \mathrm{mL}\right)$ was preincubated with inhibitors (15 min), and platelets were activated as required. Thrombin generation was initiated in PRP with tissue factor (1 pM final concentration) at $37^{\circ} \mathrm{C}$ and measured according to the thrombogram method. ${ }^{47}$ Briefly, PRP samples (4 volumes) were pipetted into a polystyrene 96-wells plate (Immulon 2HB, Dynex Technologies), already containing 1 
volume of buffer A (20 mM Hepes, $140 \mathrm{mM} \mathrm{NaCl}, 5 \mathrm{mg} / \mathrm{mL}$ BSA and $6 \mathrm{pM}$ tissue factor). Coagulation was started by adding 1 volume of buffer B (2.5 mM Z-GGR-AMC, $20 \mathrm{mM}$ Hepes, $140 \mathrm{mM} \mathrm{NaCl}, 100 \mathrm{mM} \mathrm{CaCl}$ and $60 \mathrm{mg} / \mathrm{mL}$ BSA). Fluorescence accumulation was measured with a Fluoroskan Ascent well-plate reader (Thermolab Systems), equipped with thrombinoscope software (Synapse).

\section{Flow cytometry}

Washed platelets $\left(1.0 \times 10^{8} / \mathrm{mL}\right)$ were resuspended in citrate-anticoagulated, fibrindepleted plasma. ${ }^{5}$ Coagulation was triggered with $\mathrm{CaCl}_{2}(16.6 \mathrm{mM})$ and tissue factor $(0.5$ pM, f.c.). After 10 min of activation, exposure of PS was determined by flow cytometry using FITC-labeled annexin A5.

\section{Statistical analysis}

Statistical analysis was performed with the Students t-test, using the statistical package for social sciences (SPSS 11.0). Data are presented as means \pm SEM, unless indicated otherwise.

\section{Results}

\section{Autocrine and added ADP increases and prolongs thrombin receptor-induced $\mathrm{Ca}^{2+}$ responses via $P 2 Y_{12}$ receptor stimulation}

Previously, the selective P2Y 12 antagonist, cangrelor (AR-C69931MX, AR-C), was used to demonstrate that autocrine produced ADP stimulates the procoagulant activity of thrombin-stimulated platelets exclusively via $\mathrm{P}_{2} \mathrm{Y}_{12}$ receptors; the selective $\mathrm{P} 2 \mathrm{Y}_{1}$ antagonist MRS2179 was without influence here. ${ }^{5}$ This procoagulant effect of $\mathrm{P}_{2} \mathrm{Y}_{12}$ was proposed to result from synergy with signaling via the platelet thrombin receptors. To investigate how autocrine ADP contributes to the $\mathrm{Ca}^{2+}$ response induced by thrombin, Fura-2-loaded human platelets were stimulated with low or high thrombin concentrations (0.5-20 nM), and the effects of pre- or post-addition of AR-C or MRS2179 were examined. As shown in Figure 1, AR-C pretreatment lowered the $\mathrm{Ca}^{2+}$ signal at all thrombin doses. The effect of AR-C was marked in showing a persistent reduction of 30$50 \%(p<0.05)$ of the later phase of the $\mathrm{Ca}^{2+}$ response, such in contrast to MRS2179. Interestingly, also late addition of $\mathrm{AR}-\mathrm{C}$, i.e. when given after the initial $\mathrm{Ca}^{2+}$ peak, resulted in nearly immediate abolition of the remaining part of the $\mathrm{Ca}^{2+}$ signal, which then reached the level as in platelets preincubated with AR-C. In the experiments, a concentration of 2-5 $\mu \mathrm{M}$ AR-C was sufficient for maximal reduction of the $\mathrm{Ca}^{2+}$ response, while higher concentrations of 10-30 $\mu \mathrm{M}$ did not give additional effects (not shown). In marked contrast, post-addition of MRS2179 did not affect the thrombin-induced $\mathrm{Ca}^{2+}$ response (Fig. 1). 

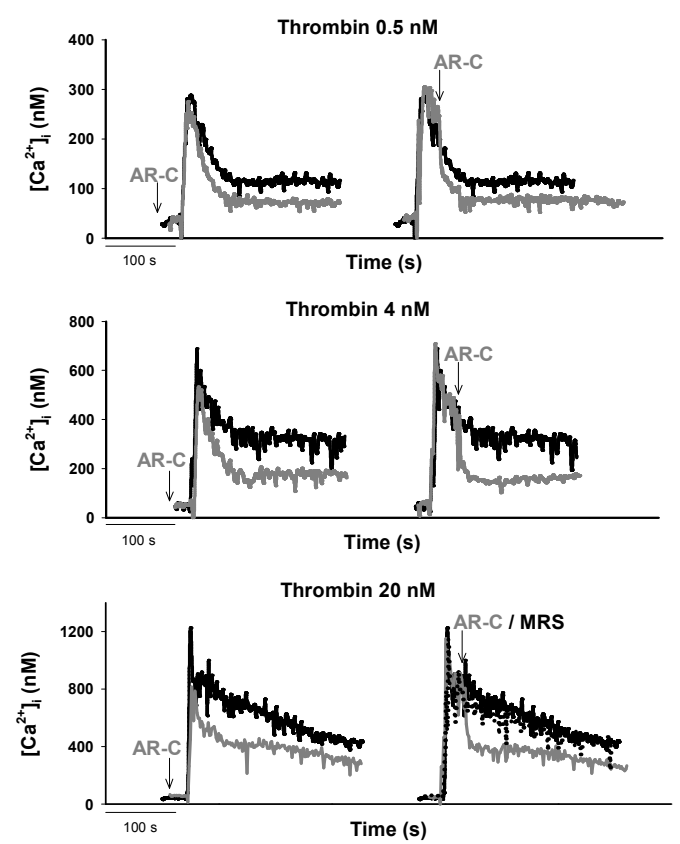

Figure 1. Autocrine ADP and $P 2 Y_{12}$ prolong thrombin-induced $\mathrm{Ca}^{2+}$ responses. Fura-2-loaded platelets were activated with thrombin $(0.5,4$ or $20 \mathrm{nM})$ in the presence of $1 \mathrm{mM} \mathrm{CaCl}_{2}$. Vehicle solution (black lines) or AR-C (10 $\mu \mathrm{M}$, grey lines) was added at $10 \mathrm{~min}$ before thrombin or shortly after thrombin (arrows). Dotted lines indicate effect of MRS2179 $(100 \mu \mathrm{M})$ addition. Traces are representative for 3 or more experiments.

To determine if the $\mathrm{P}_{2} \mathrm{Y}_{12}$ contribution to the thrombin-evoked $\mathrm{Ca}^{2+}$ response was limited by incomplete or impaired secretion, we determined how it was influenced by preor post-addition of AR-C using platelets that were co-stimulated with thrombin (4 nM) and ADP $(20 \mu \mathrm{M})$. Again, AR-C - when given before or after the agonists - greatly suppressed the late phase of the $\left[\mathrm{Ca}^{2+}\right]_{i}$ increase (Fig. 2A). Here, an AR-C concentration of 10-30 $\mu \mathrm{M}$ was needed for optimal effect (not shown). As a comparison, the general $\mathrm{PI} 3-\mathrm{K}$ inhibitor wortmannin was given after thrombin + ADP; wortmannin had a slower but similar type of effect as AR-C (Fig. 2B).

To quantify the contribution of $\mathrm{P}_{2} \mathrm{Y}_{12}$ to the $\mathrm{Ca}^{2+}$ response in platelets stimulated with $4 \mathrm{nM}$ thrombin with/without ADP, we measured not only $\left[\mathrm{Ca}^{2+}\right]_{i}$ peaks but also changes in $\left[\mathrm{Ca}^{2+}\right]_{i}$-time integrals, which reflect both the extent and duration of the $\left[\mathrm{Ca}^{2+}\right]_{i}$ increase. ${ }^{9}$ Platelet pretreatment with AR-C reduced the $\mathrm{Ca}^{2+}$ peak $(-9 \%)$ and the $\mathrm{Ca}^{2+}$ integral $(-34 \%)$ after thrombin stimulation (Table 1). Extra addition of MRS2179 was without effect, thus excluding a contribution of $\mathrm{P}_{2} \mathrm{Y}_{1}$ receptors. Co-stimulation with thrombin and ADP increased both the $\mathrm{Ca}^{2+}$ peak (+19\%) and the $\mathrm{Ca}^{2+}$ integral (+35\%) in comparison to thrombin alone. Importantly, pretreatment with AR-C reversed both parameters to the same level as seen with thrombin alone. 
A

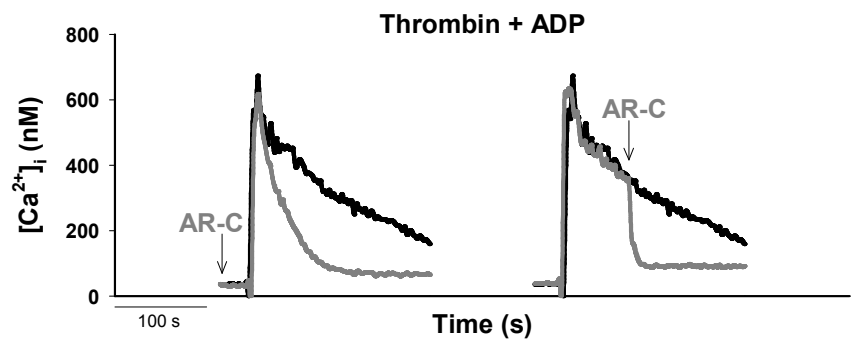

B

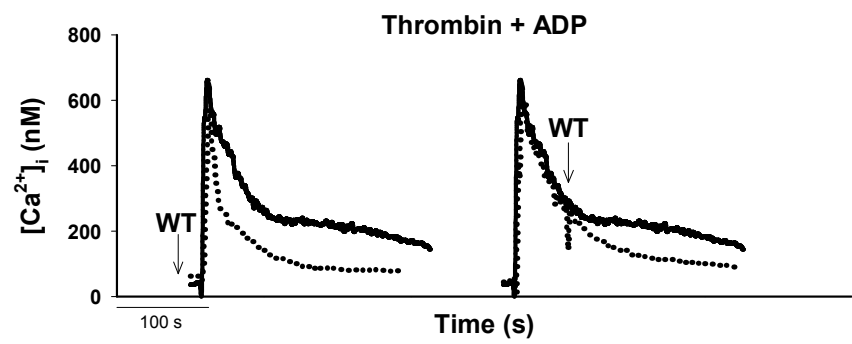

Figure 2. $\mathrm{P}^{2} \mathrm{Y}_{12}$ prolongs thrombin-induced $\mathrm{Ca}^{2+}$ responses partly via PI3-K signaling. Fura-2loaded platelets were activated with $4 \mathrm{nM}$ thrombin $+20 \mu \mathrm{M}$ ADP in the presence of $1 \mathrm{mM} \mathrm{CaCl} 2$. (A) Effect of pre- or post-addition of vehicle (black lines) or AR-C (30 $\mu \mathrm{M}$, grey lines) on the $\mathrm{Ca}^{2+}$ response. (B) Effect of pre- or post-addition of wortmannin (WT $200 \mathrm{nM}$, dotted lines) on the $\mathrm{Ca}^{2+}$ response. Traces are representative for 3 or more experiments.

Table 1. Contribution of $\mathrm{P}_{2} \mathrm{Y}_{12}$ signaling to thrombin- and ADP-induced $\mathrm{Ca}^{2+}$ responses.

\begin{tabular}{llll}
\hline Agonist & Antagonist & $\begin{array}{l}\text { Peak }(\mathrm{nM}) \\
(\% \text { versus thrombin) }\end{array}$ & $\begin{array}{l}\text { Integral (nM x s) } \\
(\% \text { versus thrombin) }\end{array}$ \\
\hline Thrombin & Vehicle & $646 \pm 38(100 \%)$ & $40173 \pm 3032(100 \%)$ \\
& AR-C & $591 \pm 69(91 \%)^{*}$ & $26513 \pm 2660(66 \%)^{*}$ \\
Thrombin + ADP & AR-C + MRS2179 & $648 \pm 142(100 \%)$ & $29064 \pm 4098(72 \%)^{* *}$ \\
& Aehicle & $767 \pm 131(119 \%)$ & $54149 \pm 7418(135 \%)^{*}$ \\
& AR-C & $603 \pm 103(93 \%)^{*}$ & $25762 \pm 2784(64 \%)^{*}$ \\
& AR-C + MRS2179 & $565 \pm 131(87 \%)^{*}$ & $23744 \pm 3421(59 \%)^{*}$ \\
\hline
\end{tabular}

Fura-2-loaded platelets $\left(1 \times 10^{8} / \mathrm{mL}\right)$ were preincubated with vehicle, AR-C $(30 \mu \mathrm{M})$, and/or MRS2179 $(100 \mu \mathrm{M})$ for $10 \mathrm{~min}$. Changes in $\left[\mathrm{Ca}^{2+}\right]_{\text {i }}$ were measured after activation with $4 \mathrm{nM}$ thrombin $\pm 20 \mu \mathrm{M}$ ADP in the presence of $1 \mathrm{mM} \mathrm{CaCl}$. Data show $\left[\mathrm{Ca}^{2+}\right]_{i}$ peak levels and $\left[\mathrm{Ca}^{2+}\right]_{i-}$ time integrals over $5 \mathrm{~min} ;{ }^{*} p<0.05,{ }^{* *} p<0.1(n=3-5)$. 
The thrombin receptors PAR1 and PAR4 have been implicated in early and late stages of thrombin-induced human platelet activation, respectively. To investigate whether PAR1 alone or in combination with PAR4 co-signals with $\mathrm{P}_{2} \mathrm{Y}_{12}$, platelets were stimulated with the PAR1 agonist SFLLRN $(15 \mu \mathrm{M}) \pm$ the PAR4 agonist AYPGKF (200 $\mu \mathrm{M}$ ). In either case, AR-C (but not MRS2179) suppressed the $\mathrm{Ca}^{2+}$ integral with a similar degree; $38 \pm 1 \%$ and $37 \pm 1 \%(n=3)$. Thus, the $\mathrm{P}_{2} \mathrm{Y}_{12}$-dependent part of the $\mathrm{Ca}^{2+}$ signal with thrombin does not rely on PAR4 activation.

Together, these results demonstrate that both autocrine released and externally added ADP reinforce the thrombin receptor-induced $\mathrm{Ca}^{2+}$ responses by a moderate increase of the first $\mathrm{Ca}^{2+}$ peak and a more marked increase of the later $\mathrm{Ca}^{2+}$ signal. Further, the strong inhibitory effect of post-added AR-C indicates that long-term signaling via $\mathrm{P}_{2} \mathrm{Y}_{12}$ receptors is needed for the prolonged thrombin-induced $\mathrm{Ca}^{2+}$ signal.

\section{$P 2 Y_{12}$ stimulation increases thrombin-induced $\mathrm{Ca}^{2+}$ mobilization from internal stores}

In order to prevent response variation due to incomplete or impaired ADP secretion, subsequent experiments were carried out by co-stimulation of platelets with fixed concentrations of thrombin and ADP. Since ADP was proposed to trigger unspecified $\mathrm{Ca}^{2+}$ entry channels, ${ }^{24}$ we measured its contribution to thrombin-induced $\mathrm{Ca}^{2+}$ signals in the presence or absence of external $\mathrm{CaCl}_{2}$. Typically, ADP increased and prolonged the $\mathrm{Ca}^{2+}$ response in either case (Fig. 3). In comparison to the condition where $\mathrm{P}_{2} \mathrm{Y}_{12}$ activity was fully blocked (+AR-C), ADP increased the thrombin-induced $\mathrm{Ca}^{2+}$ integral with $93 \pm 16 \%$ or $76 \pm 10 \%$ in the presence of $\mathrm{EGTA}$ or $\mathrm{CaCl}_{2}$, respectively (Fig. 3). This suggested that $\mathrm{P}_{2} \mathrm{Y}_{12}$ primarily stimulated mobilization of $\mathrm{Ca}^{2+}$ from internal stores, and it only secondarily enhanced store-regulated $\mathrm{Ca}^{2+}$ entry in the presence of $\mathrm{CaCl}_{2}$.

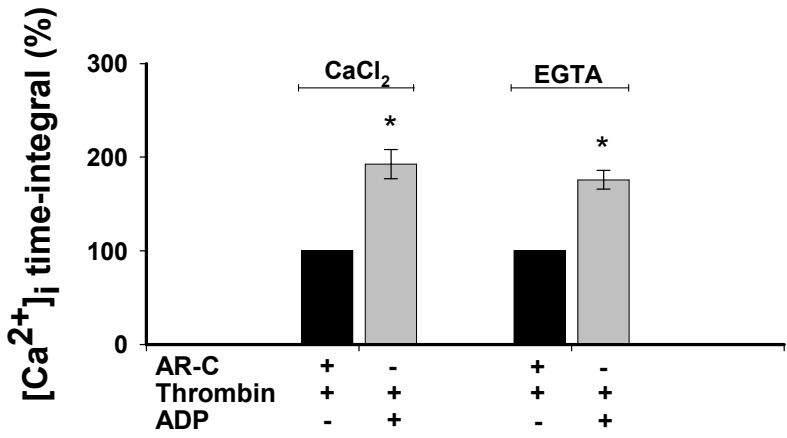

Figure 3. $\mathrm{P}_{2} \mathrm{Y}_{12}$ enhances thrombin-induced $\mathrm{Ca}^{2+}$ responses independent of $\mathrm{Ca}^{2+}$ entry. Fura2-loaded platelets were preincubated with vehicle or AR-C $(30 \mu \mathrm{M})$, and stimulated with thrombin (4 $\mathrm{nM}) \pm \operatorname{ADP}(20 \mu \mathrm{M})$ in the presence of either $1 \mathrm{mM} \mathrm{CaCl}$ or $1 \mathrm{mM}$ EGTA. Data are presented as normalized $\mathrm{Ca}^{2+}$-time integrals $(5 \mathrm{~min})$ relative to the condition of $A R-C+$ thrombin; ${ }^{*} p<0.05(n=4-6)$. 


\section{$P 2 Y_{12}$ stimulation increases Ins $P_{3}$ receptor function via PKA}

By linking to $\mathrm{Gi}, \mathrm{P}_{2} \mathrm{Y}_{12}$ inhibits adenylyl cyclase and causes inactivation of cAMPdependent protein kinase $A$ (PKA). ${ }^{14,25}$ Knowing that PKA-induced phosphorylation of platelet Ins $\mathrm{P}_{3}$ receptors inhibits their $\mathrm{Ca}^{2+}$ channel function, ${ }^{26}$ we determined how $\mathrm{P}_{2} \mathrm{Y}_{12}$ signaling affects $\mathrm{InsP}_{3}$-induced mobilization of $\mathrm{Ca}^{2+}$ from intracellular stores. Using saponin-permeabilized platelets, the $\mathrm{Ca}^{2+}$ release was measured in response to a suboptimal dose of InsP ${ }_{3}{ }^{27}$ Platelet activation with ADP had a clear stimulating effect on the InsP $\mathrm{P}_{3}$-induced $\mathrm{Ca}^{2+}$ release, while AR-C completely antagonized this effect (Fig. 4A). In marked contrast, preincubation with the PI3-K inhibitor wortmannin was ineffective.

Further experiments confirmed the sensitivity of $\mathrm{InsP}_{3}$-induced $\mathrm{Ca}^{2+}$ mobilization for modulation of PKA activity. Platelets were therefore pretreated with the PKA inhibitors, KT5720 and H89. ${ }^{28}$ Following saponin permeabilization, this resulted in increased $\mathrm{InsP}_{3}$ induced $\mathrm{Ca}^{2+}$ release with either inhibitor, with an $\mathrm{EC}_{50}$ of $1 \mu \mathrm{M} \mathrm{KT5720} \mathrm{and} 4 \mu \mathrm{M} \mathrm{H} 89$. Pretreatment with an optimal dose of $2.5 \mu \mathrm{M} \mathrm{KT5720}$ doubled the $\mathrm{Ca}^{2+}$ release with ADP (Fig. 4B). Conversely, pretreatment with the PKA-stimulating agent

A

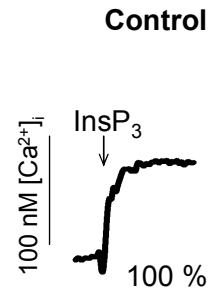

B

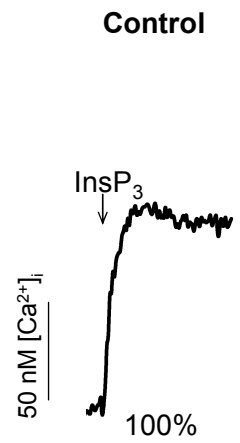

ADP
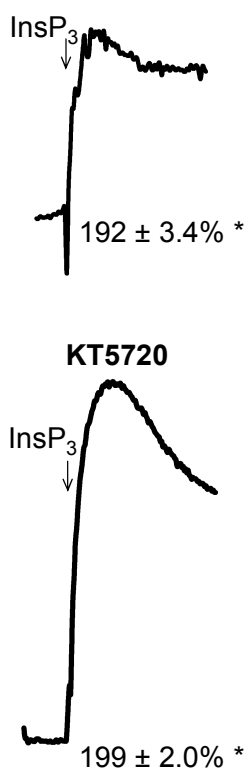

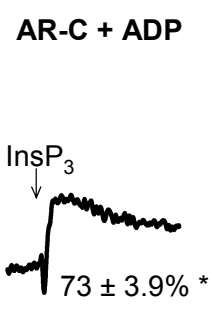

$\mathrm{PGE}_{1}$

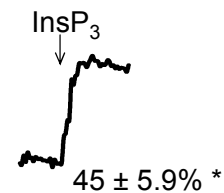

WT + ADP

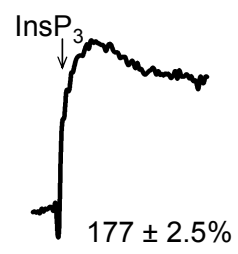

Heparin

Figure 4. $\mathrm{P}_{2} \mathrm{Y}_{12}$ enhances Ins $\mathrm{P}_{3}$-induced $\mathrm{Ca}^{2+}$ mobilization in saponin-permeabilized platelets. Washed platelets in ATP-regenerating medium were stimulated with ADP $(20 \mu \mathrm{M})$, as indicated, and permeabilized with saponin in the presence of Fluo-3. After adjustment of the free $\mathrm{Ca}^{2+}$ level to 300 $\mathrm{nM}, \mathrm{InsP}_{3}(100 \mathrm{nM})$ was added, and $\mathrm{Ca}^{2+}$ mobilization was measured. (A) Platelets were pretreated with vehicle, AR-C (30 $\mu \mathrm{M})$ or wortmannin (WT, $200 \mathrm{nM})$ for $5 \mathrm{~min}$, and then activated with ADP. (B) Platelets were pretreated with KT5720 $(2.5 \mu \mathrm{M})$, PGE $1(10 \mu \mathrm{M})$ or heparin $(20 \mu \mathrm{g} / \mathrm{mL})$. Traces of InsP $\mathrm{P}_{3}$-induced increases in $\left[\mathrm{Ca}^{2+}\right]_{i}$ are from representative experiments out of three or more performed. Values are percentages of maximal $\mathrm{Ins}_{3}$-induced $\mathrm{Ca}^{2+}$ mobilization compared to control condition; ${ }^{*} p<0.05$ compared to control $(n=3-8)$. 
prostaglandin $\mathrm{E}_{1}\left(\mathrm{IC}_{50} \quad 0.5 \mu \mathrm{M}\right)$ more than halved this $\mathrm{Ca}^{2+}$ release. In control experiments, saponin-permeabilized platelets were treated with heparin, which was used here as an established $\mathrm{InsP}_{3}$ receptor. ${ }^{29}$ Heparin completely inhibited all Ins $\mathrm{P}_{3}$-induced $\mathrm{Ca}^{2+}$ mobilization (Fig. 4B). Note that no thrombin was used in this experimental set. As an alternative way to reduce cAMP, platelets were preincubated with the Gz-coupled agonist, adrenaline. ${ }^{27}$ Similarly to $\mathrm{P}_{2} \mathrm{Y}_{12} / \mathrm{Gi}$-mediated inhibition of adenylate cyclase, this treatment resulted in a $61 \pm 10 \%$ increase of InsP $_{3}$-induced $\mathrm{Ca}^{2+}$ mobilization. Together, these results show that $P 2 Y_{12}$ receptor activation, by lowering cAMP and PKA activity, can enhance the $\mathrm{Ca}^{2+}$-mobilizing function of the $\mathrm{InsP}_{3}$ receptors.

\section{$P 2 Y_{12}$ stimulation increases $\mathrm{Ca}^{2+}$ mobilization via both PKA and PI3-K pathways}

Effects of PKA inhibition were also measured on $\mathrm{Ca}^{2+}$ responses of non-permeabilized, Fura-2-loaded platelets. Pretreatment of platelets with an optimal dose of $10 \mu \mathrm{M} \mathrm{H} 89$ resulted in an overall increase in $\mathrm{Ca}^{2+}$ integral with thrombin alone, but not with thrombin + ADP (Fig. 5). Accordingly, with $\mathrm{H} 89$ present, the contribution of ADP/P2Y 12 to the thrombin-induced $\mathrm{Ca}^{2+}$ integral reduced by $47 \%$. Basically similar results were obtained with KT5720, but these were difficult to quantify because this compound strongly interfered with Fura-2 fluorescence (not shown). The ADP/P2Y 12 effect on the thrombininduced $\mathrm{Ca}^{2+}$ response was independent of integrin signaling, since in platelets treated with the $\alpha$ llb $\beta 3$ antagonist, tirofiban, it changed insignificantly from $176 \%$ to $167-170 \%$.

The contribution of PI3-K was further examined using two structurally distinct inhibitors, wortmannin and LY294002. ${ }^{21}$ In the presence of ADP/P2Y 12 activity, wortmannin or LY294002 suppressed the thrombin-induced $\mathrm{Ca}^{2+}$ integral with an $\mathrm{IC}_{50}$ of

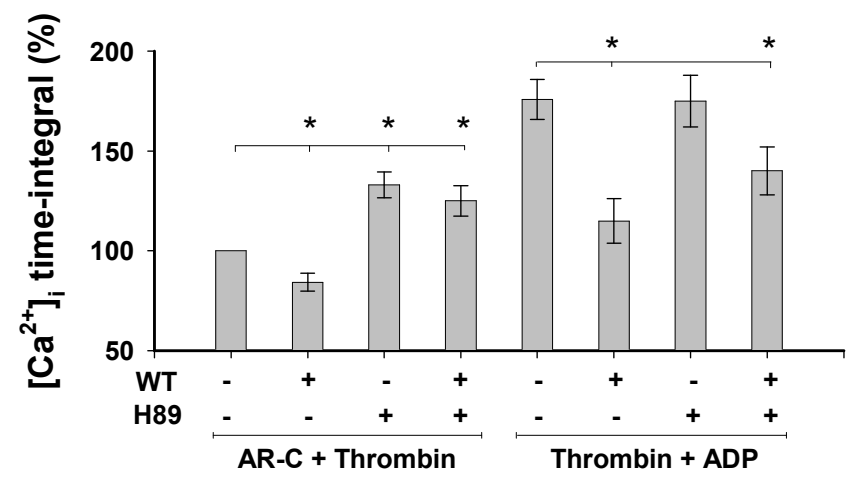

Figure 5. $\mathrm{P}_{2} \mathrm{Y}_{12}$ enhances thrombin-induced $\mathrm{Ca}^{2+}$ responses via both PKA and PI3-K. Fura-2loaded platelets in $1 \mathrm{mM}$ EGTA were preincubated with vehicle, AR-C $(30 \mu \mathrm{M}), \mathrm{H} 89(10 \mu \mathrm{M})$ and/or wortmannin (WT, $200 \mathrm{nM}$ ), as indicated. Platelets were activated with $4 \mathrm{nM}$ thrombin in combination with either $30 \mu \mathrm{M}$ AR-C or $20 \mu \mathrm{M}$ ADP, as in Fig. 3. Data are presented as normalized $\left[\mathrm{Ca}^{2+}\right]$ i-time integrals relative to the condition of AR-C + thrombin. ${ }^{*} p<0.05$ compared to respective control $(n=5-$ $6)$. 
about $10 \mathrm{nM}$ and $1 \mu \mathrm{M}$, respectively, which is in accordance with the known affinity of these compounds for the PI3-K catalytic subunits. At these concentrations (required for notable inhibition of Akt phosphorylation, see below), wortmannin and LY294002 reduced the $\mathrm{Ca}^{2+}$ integral with $24.4 \pm 4.1 \%$ and $24.0 \pm 1.7 \%(n=3)$, respectively. In contrast, when AR-C was present and $\mathrm{P}_{2} \mathrm{Y}_{12}$ was not active, these compounds influenced the thrombin-induced $\mathrm{Ca}^{2+}$ mobilization insignificantly with $<6 \% \quad(p=0.34)$. Figure 5 shows that wortmannin, at a maximally effective dose of $200 \mathrm{nM}$, suppressed the thrombin + ADP response with $35 \pm 3.4 \%$. Notably, when combined with $\mathrm{H} 89$ to block PKA, wortmannin treatment almost completely abolished the stimulating effect of ADP (Fig. 5). In other words, combined antagonism of PKA and PI3-K was sufficient to nearly completely block the ADP/P2Y 12 effect on thrombin-induced $\mathrm{Ca}^{2+}$ mobilization.

\section{$P 2 Y_{12}$ stimulation increases $\mathrm{Ca}^{2+}$ mobilization via prolonged phospholipase $\mathrm{C}$ activity}

The PI3-K pathway might enhance $\mathrm{Ca}^{2+}$ mobilization by reducing $\mathrm{Ca}^{2+}$ removal via SERCA inhibition, in a way similar as proposed for pancreatic acinar cells. ${ }^{30}$ In platelets, the SERCA inhibitor thapsigargin prolonged the thrombin-induced $\mathrm{Ca}^{2+}$ response, and abolished the effects of ADP, AR-C and wortmannin on this response (Fig. 6A, B). Wortmannin pretreatment did not change the decay rate of the $\mathrm{Ca}^{2+}$ signal with thrombin + ADP. Direct measurement of SERCA activity in saponin-permeabilized platelets showed that neither AR-C nor wortmannin decreased this activity with $<3 \%$. Together, this indicates that $A D P / P 2 Y_{12}$ activity prolongs $\mathrm{Ca}^{2+}$ mobilization in a way that requires normal SERCA activity. However, the data do not provide evidence for a direct effect of $\mathrm{P}_{2} \mathrm{Y}_{12} / \mathrm{PI} 3-\mathrm{K}$ on SERCA activity in platelets.

If $\mathrm{PI}-\mathrm{K}$ does not affect $\mathrm{Ca}^{2+}$ reuptake, it may enhance or prolong the activation of phospholipase $\mathrm{C}$, in particular its $\gamma$-isoforms which partly rely on $\mathrm{PIP}_{3}$ formation. ${ }^{31}$ To explore this possibility, platelets were stimulated with thrombin + ADP, after which phospholipase C-inhibiting agents were added. Post-addition of the phospholipase $\mathrm{C}$ inhibitor U73122 completely abrogated the prolonged phase of the $\mathrm{Ca}^{2+}$ response, while the control substance U73343 was ineffective (Fig. 6C, D). As U73122 can have nonspecific effects, control experiments were performed with other phospholipase $\mathrm{C}$ inhibitors, ET-18- $\mathrm{OCH}_{3}$ and manoalide. Similarly, post-addition of these compounds blocked the prolonged phase of the $\mathrm{Ca}^{2+}$ response (Fig. 6D). As mentioned above, a similar but slower effect was obtained by post-addition of wortmannin (Fig. 2B). To confirm that PI3-K contributes to late phospholipase $\mathrm{C}$ activation, levels of $\mathrm{InsP}_{3}$ were measured in platelets stimulated for 5 min with thrombin + ADP. This stimulation resulted in a $1.73 \pm 0.16$ fold increase in $\operatorname{lns}_{3}$, which was significantly reduced to $1.43 \pm 0.20$ fold in the presence of wortmannin $(p=0.02, n=6)$. Together, these results indicate that the ADP/P2Y 12 -dependent prolongation of the $\mathrm{Ca}^{2+}$ response relies on both phospholipase $\mathrm{C}$ and PI3-K activity. 
A

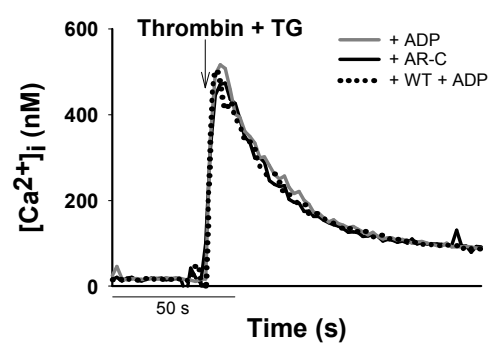

C

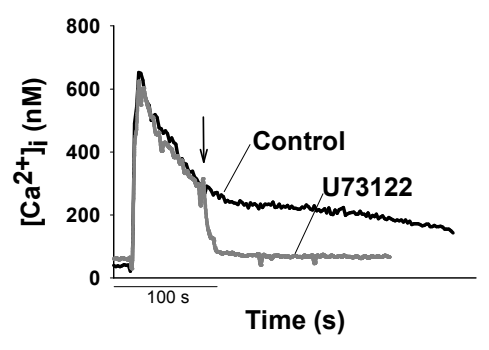

B

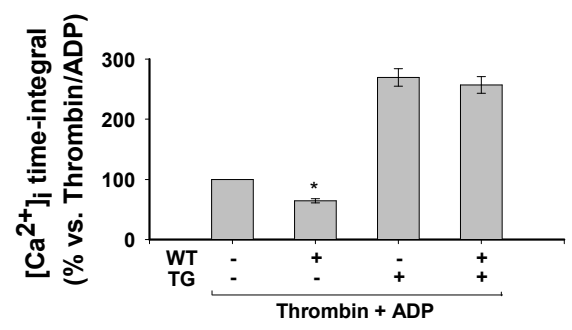

D

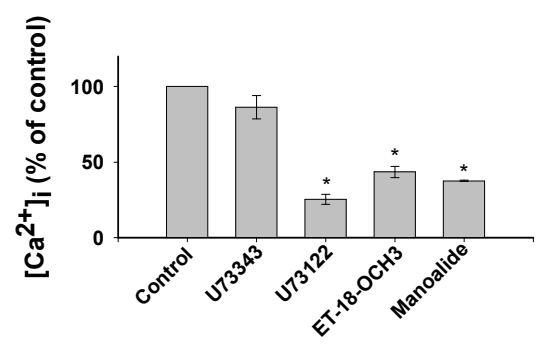

Figure 6. Contribution of SERCA and phospholipase $C$ to $P 2 Y_{12}$-dependent prolongation of $\mathrm{Ca}^{2+}$ responses. (A, B) Fura-2-loaded platelets were preincubated with vehicle, AR-C $(30 \mu \mathrm{M})$ or wortmannin (WT, $200 \mathrm{nM}$ ) for $10 \mathrm{~min}$, as indicated. Platelets then were stimulated with thrombin (4 $\mathrm{nM}) \pm \mathrm{ADP}(20 \mu \mathrm{M})$ in the presence or absence of thapsigargin (TG, $2 \mu \mathrm{M})$. Bars show quantitative effect of wortmannin relative to thrombin + ADP. (C, D) Fura-2-loaded platelets were stimulated with thrombin and ADP as above. At $60 \mathrm{~s}$ after activation (arrow), the following substances were added: vehicle (control), U73343 $(2 \mu \mathrm{M})$, U73122 $(2 \mu \mathrm{M})$, ET-18-OCH $(40 \mu \mathrm{M})$ or manoalide $(10 \mu \mathrm{M})$. Bars give $\mathrm{Ca}^{2+}$ levels, relative to thrombin + ADP, measured at $60 \mathrm{~s}$ after addition of indicated substance. Representative $\mathrm{Ca}^{2+}$ traces are shown $(n=3-5)$.

\section{The PI3-K $\beta$ and not the PI3-K $\gamma$ isoform mediates the $P 2 Y_{12}$ effect on thrombin- evoked $\mathrm{Ca}^{2+}$ responses}

In man and mouse, the PI3-K $\beta$ (p110 3 ) and $\mathrm{PI3}-\mathrm{K} \gamma(\mathrm{p} 110 \gamma)$ isoforms are involved in $P 2 Y_{12}$-dependent platelet aggregation. ${ }^{19,21,32}$ To examine how these isoforms contribute to the $\mathrm{Ca}^{2+}$ signal, the PI3-K $\beta$ selective inhibitor TGX221 ${ }^{21}$ was used and platelets from $\mathrm{p} 110 \gamma^{-1-}$ mice, lacking active PI-3K $\gamma$. It was established that, in murine platelets, TGX221 dose-dependently inhibited PI3-K-dependent phosphorylation of Akt; full inhibition was achieved at a concentration of $0.5 \mu \mathrm{M}$ (not shown, but see below). Typically, platelets from wildtype $\mathrm{p} 110 \gamma^{+/+}$and knockout $\mathrm{p} 110 \gamma^{-/-}$mice showed a similar enhancement with ADP of the thrombin-induced $\mathrm{Ca}^{2+}$ response, which was always inhibited by AR-C (Fig. 7A). In either genotype, this enhancement also antagonized by the general PI3-K inhibitor LY294002 (Fig. 7B), and by the PI3-Kß specific inhibitor TGX221 (Fig. 7C).

Similar results were obtained with human platelets, showing that pretreatment with TGX221 was almost as active as wortmannin in suppressing the 
A
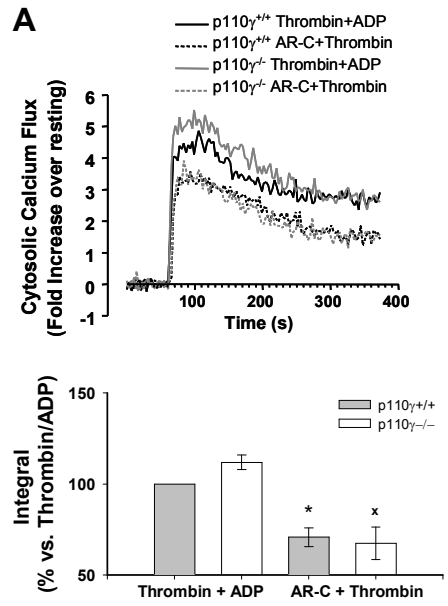

B

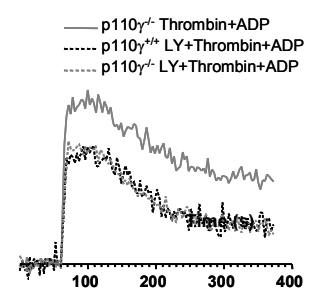

C
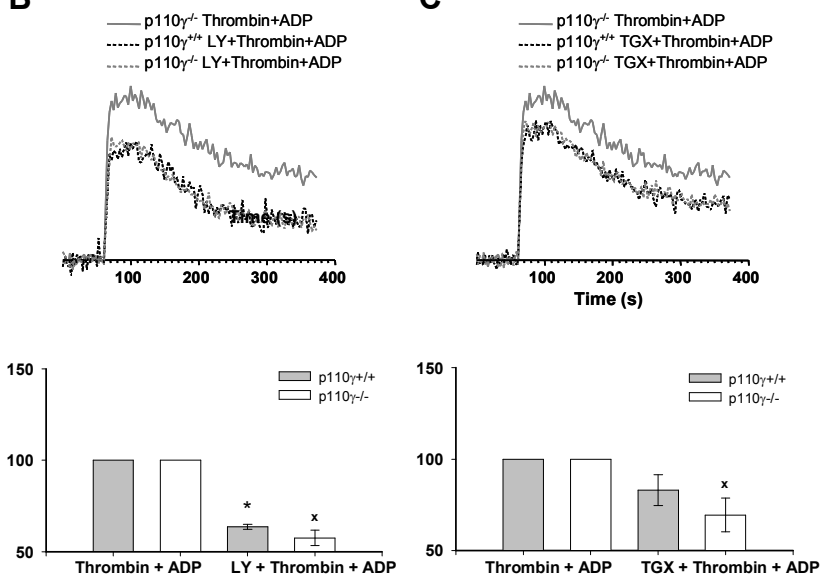

Figure 7. Unchanged contribution of $\mathrm{P}_{2} \mathrm{Y}_{12}$ to $\mathrm{Ca}^{2+}$ responses in $\mathrm{PI} 3-\mathrm{K} \gamma$ deficient platelets. Washed platelets, obtained from $\mathrm{p} 110 \gamma^{+/+}$and $\mathrm{p} 110 \gamma^{-1-}$ mice, were loaded with $\mathrm{Ca}^{2+}$ indicator dyes. Changes in $\left[\mathrm{Ca}^{2+}\right]_{\text {i }}$ were monitored after preincubation of the platelets with inhibitor $(10 \mathrm{~min})$, and stimulation with thrombin alone $(4 \mathrm{nM})$ or in combination with ADP $(20 \mu \mathrm{M})$. (A) Effect of AR-C (10 $\mu \mathrm{M})$ preincubation on $\mathrm{Ca}^{2+}$ response. (B) Effect of general PI3-K inhibitor LY294002 (LY, $\left.25 \mu \mathrm{M}\right)$ on $\mathrm{Ca}^{2+}$ response. (C) Effect of PI3-K $\beta$ inhibitor TGX221 (TGX, $\left.0.5 \mu \mathrm{M}\right)$ on $\mathrm{Ca}^{2+}$ response. Graphs are representative and show fold increases in $\left[\mathrm{Ca}^{2+}\right]_{i}$ after agonist stimulation. Bars give $\left[\mathrm{Ca}^{2+}\right]_{\text {itime }}$ integrals, expressed relative to values with thrombin + ADP ( $n=4$, duplicate experiments).

thrombin + ADP-induced $\mathrm{Ca}^{2+}$ response (Fig. 8A). On the other hand, pretreatment with the PI3-K $\gamma$-specific inhibitor, AS252424, ${ }^{21}$ was without effect. As protein kinase B/Akt is a downstream mediator of $\mathrm{PI} 3-\mathrm{K}$ in platelets, ${ }^{33,34}$ effects of the isoform-specific inhibitors were examined on thrombin + ADP-induced Akt activation. In platelets that were stimulated with thrombin alone or in combination with ADP, Akt was phosphorylated at its activation site of $\mathrm{Ser}^{473}$, peaking after 5-10 min. This phosphorylation was completely absent in the presence of the $\mathrm{P}_{2} \mathrm{Y}_{12}$ antagonist AR-C, regardless of whether ADP was added or not (Fig. 8B, C). Furthermore, pretreatment with LY294002 or TGX221 caused complete inhibition of the thrombin + ADP-evoked $\mathrm{Ser}^{473}$ phosphorylation of Akt (Fig. 8D). Apparently, in thrombin-stimulated platelets, Akt phosphorylation and activation is completely dependent on autocrine produced or externally added ADP, via stimulation of the $\mathrm{P}_{2} \mathrm{Y}_{12}$ and $\mathrm{PI}-\mathrm{K} \beta$ pathway These results not only show that the regulatory role for $\mathrm{PI} 3-\mathrm{K}$ in $\mathrm{P}_{2} \mathrm{Y}_{12}$ signaling is conserved in mouse and human platelets, but also highlight the importance of the $\mathrm{PI}-\mathrm{K} \beta$ isoform.

\section{The PI3-K $\beta$ and not the PI3-K isoform mediates $P 2 Y_{12}$-dependent procoagulant activity of mouse and human platelets}

Prolonged elevation in $\left[\mathrm{Ca}^{2+}\right]_{i}$ can signal for surface exposure of $\mathrm{PS}$, thus facilitating platelet-dependent thrombin generation. ${ }^{9}$ It was thus studied whether the $\mathrm{P} 2 \mathrm{Y}_{12} / \mathrm{PI} 3-\mathrm{K} \beta$ pathway contributed to thrombin generation. In PRP from wildtype and 
A

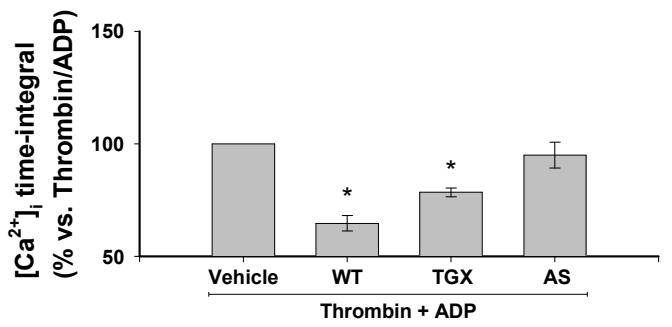

B
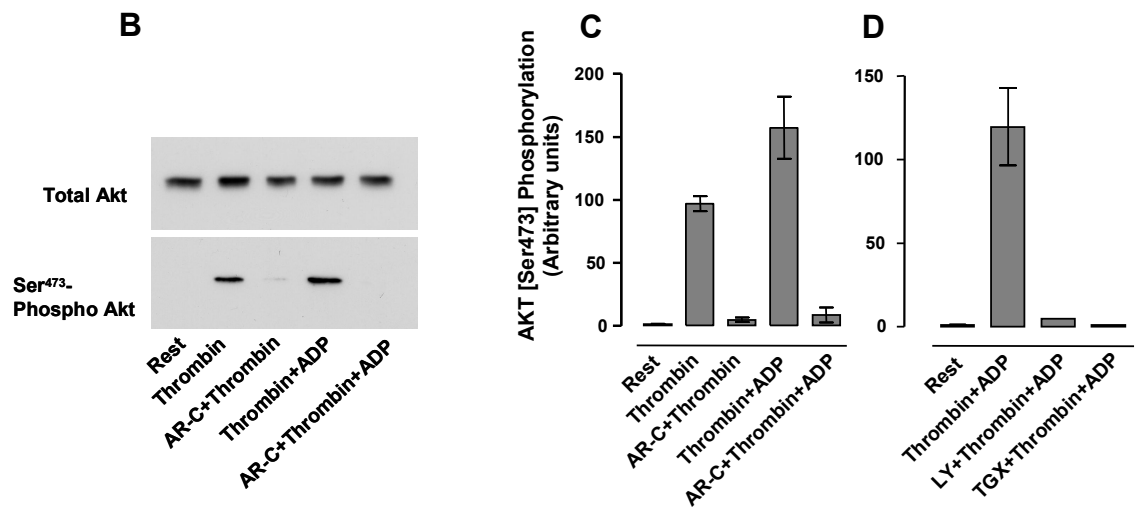

Figure 8. PI3-K $\beta$-isoform mediates $\mathrm{P} \mathrm{Y}_{12}$-dependent enhancement of platelet activation by thrombin. (A) Human, Fura-2-loaded platelets were preincubated with vehicle, wortmannin (WT, $200 \mathrm{nM}$ ), TGX221 (TGX, $0.5 \mu \mathrm{M}$ ) or AS252424 (AS, $1 \mu \mathrm{M}$ ). Cells were then stimulated by thrombin $(4 \mathrm{nM})$ and $\operatorname{ADP}(20 \mu \mathrm{M})$. Effects are shown of preincubation on $\mathrm{Ca}^{2+}$-time integrals $(\mathrm{n}=4-6$, relative to thrombin + ADP). (B-D) Washed platelets were preincubated with AR-C $(10 \mu M)$, LY294002 (LY, $25 \mu \mathrm{M})$ or TGX221 (TGX, $0.5 \mu \mathrm{M}$ ) for $10 \mathrm{~min}$. Platelets remained then unstimulated (rest), or were stimulated with thrombin \pm ADP (as above), then boiled in the presence of reducing buffer. Equal volumes of platelet samples were analyzed for Akt activation by western blot. Images are from one representative of four independent experiments. Bars show density of Akt phosphorylation on Ser ${ }^{473}$ $(n=4)$.

$\mathrm{p} 110 \gamma^{-/-}$mice, lacking PI3-K $\gamma$, thrombin generation was induced by triggering with tissue factor/ $\mathrm{CaCl}_{2}$. In either genotype, activation with $A D P$ via $\mathrm{P} 2 \mathrm{Y}_{12}$ resulted in a quite similar increase in thrombin generation (Fig. 9A, B). In PRP from all mice, TGX221 partly antagonized the stimulating effect of $A D P$, reducing the rate of thrombin generation by $\sim 25 \%$.

Similar experiments were conducted with human PRP. Also in the human system, ADP enhanced the thrombin generation triggered by tissue factor $/ \mathrm{CaCl}_{2}$ in a way inhibitable by AR-C (Fig. 10A). Pretreatment of PRP with wortmannin or TGX221 reduced the initial rate of thrombin generation about half as effective as AR-C (Fig. 10B, C). In contrast, pretreatment with the PI3-Ky inhibitor AS252424 was without any effect. Controls showed that neither wortmannin nor TGX221 affected the thrombin generation in the presence of AR-C (not shown). With only wortmannin present, the PKA inhibitor $\mathrm{H} 89$ further reduced the rate of thrombin generation with another $25 \%$, thus pointing to 
A

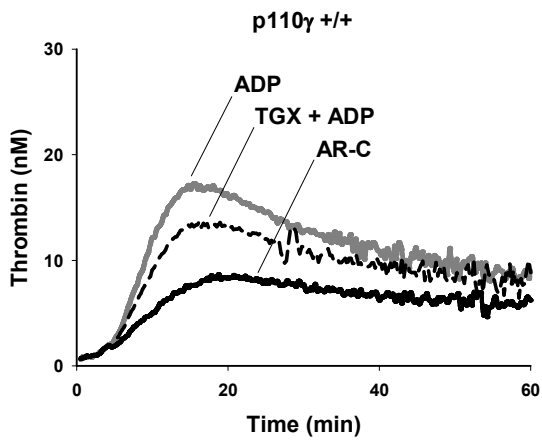

B

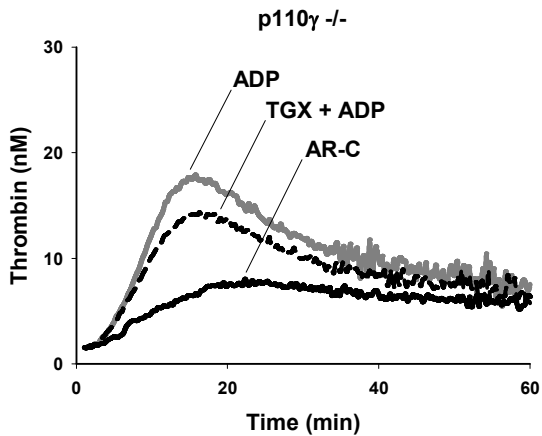

Figure 9. PI3-K $\beta$-isoform mediates $\mathrm{P}_{2} \mathrm{Y}_{12}$-dependent stimulation of coagulation in wildtype and PI3-K $\gamma$ deficient mice. PRP from (A) $\mathrm{p} 110 \gamma^{+/+}$or (B) $\mathrm{p} 110 \gamma^{-1-}$ mice was pretreated with vehicle, AR-C $(30 \mu \mathrm{M})$ or TGX221 (TGX, $0.5 \mu \mathrm{M})$ and activated with ADP. Coagulant activity was measured by the thrombin generation assay, after triggering with tissue factor/ $\mathrm{CaCl}_{2}$. Representative thrombin generation curves are given for wildtype and $\mathrm{p} 110 \gamma^{-{ }^{-}} \mathrm{PRP}$.

A

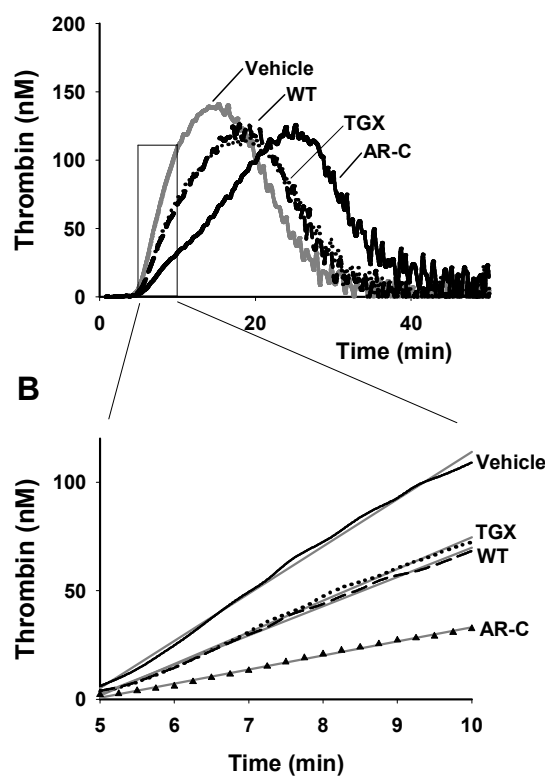

C

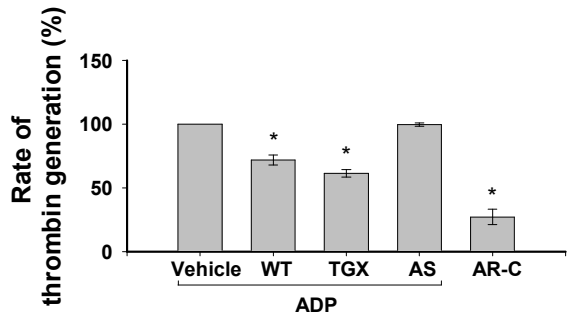

D

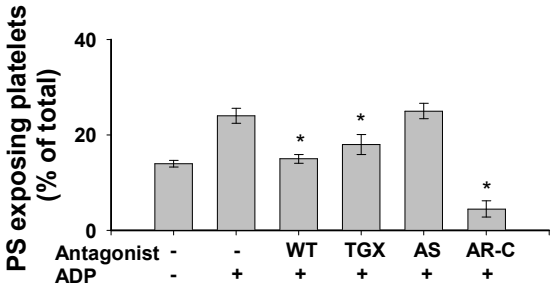

Figure 10. PI3-K $\beta$-isoform mediates $\mathrm{P}^{2} \mathrm{Y}_{12}$-dependent stimulation of coagulation and PS exposure. Human PRP was preincubated with vehicle, wortmannin (WT, $200 \mathrm{nM})$, AR-C (30 $\mu \mathrm{M})$, TGX221 (TGX, $0.5 \mu \mathrm{M})$ or AS252424 (AS, $1 \mu \mathrm{M})$, and then activated with ADP $(20 \mu \mathrm{M})$. Thrombin generation was measured by triggering with tissue factor/ $\mathrm{CaCl}_{2}$. (A) Traces are representative thrombin generation curves, showing treatment effects of AR-C, WT and TGX221. (B) Panel shows initials part of the same thrombin generation curves. (C) Bars show preincubation effects on initial rates (5 $\mathrm{min}$ ) of thrombin generation $(n=3-5)$. (D) Human platelets in fibrin-depleted human plasma were preincubated with inhibitors and activated with tissue factor/ $\mathrm{CaCl}_{2}$. After $10 \mathrm{~min}$, FITC-labeled annexin A5 was added, and fractions of PS-exposing platelets were determined by flow cytometry $(n=3-5)$. 
additional involvement of PKA. To assess more directly the role of the $\mathrm{P} 2 \mathrm{Y}_{12} / \mathrm{PI}-\mathrm{K} \beta$ pathway in procoagulant activity, effects of ADP were examined on PS exposure in PRP that was triggered with tissue factor/ $\mathrm{CaCl}_{2}$. Plasma was depleted from fibrinogen to prevent formation of clots. Flow cytometric analysis using FITC-labeled annexin A5 (detecting exposed PS) showed that ADP increased the fraction of PS-exposing platelets by $70 \%$ (Fig. 10D). Wortmannin pretreatment almost fully antagonized this increase, while TGX221 pretreatment was somewhat less inhibitory, and AS252424 was ineffective. Taken together, these results suggest that in both mouse and human platelets, the $\beta$ but not the $\gamma$ PI3-K isoform contributes to platelet procoagulant activity following $\mathrm{P}_{2} \mathrm{Y}_{12}$ stimulation.

\section{Discussion}

The present results highlight the importance of the 'weak' agonist, ADP, as a key platelet activator that is effective at low and high thrombin concentrations as well as under coagulant conditions, where thrombin is generated in situ. We find that (autocrine) ADP, acting via $\mathrm{P}_{2} \mathrm{Y}_{12}$, enhances and extends the thrombin-induced platelet activation by increasing $\mathrm{Ca}^{2+}$ mobilization from internal stores, without directly affecting a specific $\mathrm{Ca}^{2+}$ entry channel, as was previously suggested. This potentiation by $\mathrm{P}_{2} \mathrm{Y}_{12}$ signaling is conserved between platelets from man and mouse, and thus is irrespective of the different thrombin receptor types employed by these species. The data are well compatible with the earlier findings that $\mathrm{P}_{2} \mathrm{Y}_{12}$ activates platelets mostly or exclusively via $\mathrm{Gi}^{14,25}$ whereas thrombin and $\mathrm{P}^{14 \mathrm{Y}_{1}}$ stimulate the $\mathrm{Gq}$ pathway, which is directly coupled to $\mathrm{Ca}^{2+}$ mobilization. ${ }^{35}$ The present results are also in agreement with another paper, showing that $\mathrm{P}_{2} \mathrm{Y}_{12}$ activation enhances the $\mathrm{Ca}^{2+}$ response induced by thrombin receptor-activating peptide. ${ }^{36}$ Thus, in the presence of thrombin, the $\mathrm{Gi}$ signaling pathway via $\mathrm{P}_{2} \mathrm{Y}_{12}$ provides platelets with a mechanism to extend their activation.

Platelet and mature megakaryocytic Ins $\mathrm{P}_{3}$ receptors are sensitive to small changes in cAMP levels and ensuing PKA activation. ${ }^{27,28}$ This sensitivity is likely regulated by PKA phosphorylation sites, present in the type-I InsP $\mathrm{P}_{3}$ receptor $\mathrm{Ca}^{2+}$ channels, which control the $\mathrm{Ca}^{2+}$-mobilizing properties of platelets. ${ }^{26}$ The current data indicate that ADP, acting via $P_{2} Y_{12}$ and $\mathrm{Gi}$, can down-regulate adenylyl cyclase and hence PKA with consequently increased $\mathrm{Ca}^{2+}$ mobilization. This pathway still operates in the presence of thrombin, e.g. exemplified by the fact the PKA inhibitor $\mathrm{H} 89$ reinforces the thrombin-induced $\mathrm{Ca}^{2+}$ response when $\mathrm{P} 2 \mathrm{Y}_{12}$ is active.

In addition, this study demonstrates an important role for PI3-K in the $\mathrm{P}_{2} \mathrm{Y}_{12}$ dependent enhancement of thrombin receptor signaling, which is most prominent in the late stage of the $\mathrm{Ca}^{2+}$ response and is quite substantial in longer-term $\mathrm{Ca}^{2+}$ integrals. This long $\mathrm{Ca}^{2+}$ signal is shortened by PI3-K inhibition with wortmannin or LY294002. It apparently does not implicate modulation of the $\operatorname{InsP}_{3}$ receptor $\mathrm{Ca}^{2+}$ channels, as the Ins $\mathrm{P}_{3}$-induced $\mathrm{Ca}^{2+}$ mobilization is not affected by $\mathrm{PI} 3-\mathrm{K}$ inhibition. As wortmannin and the prototype PI-3K inhibitor, ${ }^{21}$ LY294002, had similar shortening effects on the $\mathrm{Ca}^{2+}$ 
response evoked by thrombin + ADP, we do not have evidence that LY294002 may affect this response in an aspecific way, as was proposed for smooth muscle cells. ${ }^{37}$

Platelets from $\mathrm{PI} 3-\mathrm{K} \gamma$ deficient mice exhibited unchanged $\mathrm{Ca}^{2+}$ response and procoagulant activity, while the PI3-K $\beta$ inhibitor TGX221 suppressed this response in both wildtype and deficient platelets. Similarly, in human platelets, TGX221 but not the PI3-K $\gamma$ specific inhibitor, AS252424, antagonized the $\mathrm{P}_{2} \mathrm{Y}_{12}$-dependent part of the $\mathrm{Ca}^{2+}$ response, indicating that $\mathrm{PI}-\mathrm{K} \beta$ is the main isoform in $\mathrm{Ca}^{2+}$ signal modulation via $\mathrm{P} 2 \mathrm{Y}_{12}$. Examination of targets downstream of $\mathrm{P} 2 \mathrm{Y}_{12}$ revealed a clear role for $\mathrm{PI} 3-\mathrm{K} \beta$ in the regulation of Akt activation, in platelets stimulated with thrombin + ADP. This agrees well with the earlier finding, in mouse platelets, that Akt is activated downstream of $\mathrm{Gi}$ and G12/13. ${ }^{33,38}$ However, under the present conditions of thrombin + ADP receptor stimulation, we could not confirm that also PI3-K $\gamma$ contributes to Akt activation ${ }^{19}$ or to $\mathrm{Ca}^{2+}$ mobilization. ${ }^{32}$

The mechanism whereby $\mathrm{PI} 3-\mathrm{K} \beta$ enhances $\mathrm{Ca}^{2+}$ signaling is not entirely clear. Its effect relies on SERCA activity, as it disappears in the presence of thapsigargin. However, in contrast to a report on pancreatic acinar cells, where PI3-K inhibition increased $\mathrm{Ca}^{2+}$ mobilization via SERCA activation, ${ }^{30} \mathrm{PI}-3 \mathrm{~K}$ inhibition did not alter SERCA activity in platelets. This suggests that not the $\mathrm{Ca}^{2+}$ reuptake itself is controlled by $\mathrm{PI} 3-\mathrm{K}$, but a different process which is still dependent on normal $\mathrm{Ca}^{2+}$-ATPase function.

A remarkable finding is that the persistent effect of $\mathrm{P}_{2} \mathrm{Y}_{12}$ on $\mathrm{Ca}^{2+}$ mobilization relies on prolonged phospholipase $\mathrm{C}$ activation. Similarly to $\mathrm{AR}-\mathrm{C}$, late application of each of the three phospholipase $\mathrm{C}$ inhibitors, U73122, $\mathrm{ET}-18-\mathrm{OCH}_{3}$ or manoalide, rapidly abolished the remaining $\mathrm{Ca}^{2+}$ response. Late application of wortmannin to block $\mathrm{PI}-\mathrm{K}$ had a similar though slower effect. That PI3-K contributes to phospholipase $\mathrm{C}$ activity was further confirmed by the finding that treatment with wortmannin suppressed the cytosolic $\mathrm{InsP}_{3}$ level in thrombin + ADP stimulated platelets. Knowing that the PI3-K $\beta$ isoform is responsible for a considerable part of the $\mathrm{PIP}_{3}$ formed in platelets, ${ }^{21}$ this may suggest that the $\mathrm{PIP}_{3}$ produced by this isoform leads to the plasma membrane binding and, hence, activation of $\mathrm{PH}$ domain-containing phospholipase $\mathrm{C} \gamma$. Indeed, thrombin (via ADP?) has been shown to provoke activation of phospholipase $C_{\gamma}$ along with phospholipase $\mathrm{C} \beta$ isozymes. ${ }^{39}$ A similar mechanism of prolonged $\mathrm{Ca}^{2+}$ signaling by $\mathrm{PIP}_{3}$ and membrane translocation of phospholipase $\mathrm{C}_{\gamma}$ has been proposed for other cell types. $^{31}$

In experiments where thrombin is induced in situ by activation of PRP with tissue factor and $\mathrm{CaCl}_{2}$, we find that the $\mathrm{P}_{2} \mathrm{Y}_{12} / \mathrm{PI}-\mathrm{K}$ pathway significantly enhances the activation state and, hence, the procoagulant activity of platelets. Experiments with inhibitors and $\mathrm{PI} 3-\mathrm{K} \gamma$ deficient mice, indicated that especially the $\mathrm{PI}-\mathrm{K} \beta$ isoform is involved. Flow cytometry further indicated that the PI3-K pathway increased the fraction of platelets with PS exposure under these conditions. Since PS exposure is a strongly $\mathrm{Ca}^{2+}$-dependent response, that in turn mediates thrombin generation, this indicates that $\mathrm{P}_{2} \mathrm{Y}_{12}$ signaling via $\mathrm{PI}-\mathrm{K} \beta$ plays a regulating role in the positive feedback loop of thrombin-induced platelet activation, platelet procoagulant activity, and new thrombin 
formation. These data thereby support the earlier finding that ADP enhances the procoagulant activity of platelets via the $\mathrm{P} 2 \mathrm{Y}_{12}$ receptors. ${ }^{5,22,23}$

The present results significantly extend the earlier work where the interaction of $P 2 Y_{12}$ with $P 2 Y_{1}$ signaling was investigated. ${ }^{25,40}$ We find that $P 2 Y_{12}$ enhances the thrombin-induced $\mathrm{Ca}^{2+}$ response in a way not only involving adenylyl cyclase/PKA inhibition, but also by $\mathrm{PI} 3-\mathrm{K}$ stimulation. $\mathrm{P}_{2} \mathrm{Y}_{12}$ appears to increase the $\mathrm{InsP}_{3}$ receptor function via PKA inhibition. This effect is further enlarged by a PI3-K $\beta$-dependent prolongation of phospholipase $\mathrm{C}$ activation and $\mathrm{InsP}_{3}$ production (see scheme in supplementary Fig. S1). The data thereby reveal a novel function for the $\beta$-isoform of PI3-K. Earlier, this isoform has been linked to shear-dependent activation of platelets, regulating the stability of platelet adhesion and aggregation. ${ }^{20,21}$ We now advocate that $\mathrm{PI} 3-\mathrm{K} \beta$ also plays a role in the prolongation of thrombin-induced $\mathrm{Ca}^{2+}$ signaling via $\mathrm{P}_{2} \mathrm{Y}_{12}$.

\section{Acknowledgements}

This work was supported by the Netherlands Organization for Scientific Research (90216-276) and the Netherlands Heart Foundation (2002B014).

\section{Supplementary material}

The following supplementary material is available online:

Fig. S1. Proposed role of the $\mathrm{P}_{2} \mathrm{Y}_{12}$ receptor in regulating $\mathrm{Ca}^{2+}$ signaling and platelet procoagulant activity. For explanation see text. 


\section{References}

1. Falati S, Gross P, Merrill-Skoloff G, Furie BC, Furie B. Real-time in vivo imaging of platelets, tissue factor and fibrin during arterial thrombus formation in the mouse. Nat Med. 2002;8:1175-1181.

2. Mackman N. Tissue-specific hemostasis in mice. Arterioscler Thromb Vasc Biol. 2005;25:2273-2281.

3. Munnix IC, Strehl A, Kuijpers MJ, Auger JM, van der Meijden PE, van Zandvoort MA, oude Egbrink MG, Nieswandt B, Heemskerk JW. The glycoprotein VI-phospholipase C $\gamma 2$ signaling pathway controls thrombus formation induced by collagen and tissue factor in vitro and in vivo. Arterioscler Thromb Vasc Biol. 2005;25:2673-2678.

4. Mangin P, Yap CL, Nonne C, Sturgeon SA, Goncalves I, Yuan Y, Schoenwaelder SM, Wright $\mathrm{CE}$, Lanza $\mathrm{F}$, Jackson SP. Thrombin overcomes the thrombosis defect associated with platelet GPVI/FcR $\gamma$ deficiency. Blood. 2006;107:4346-4353.

5. van der Meijden PE, Feijge MA, Giesen PL, Huijberts M, van Raak LP, Heemskerk JW. Platelet $P 2 Y_{12}$ receptors enhance signaling towards procoagulant activity and thrombin generation $\mathrm{A}$ study with healthy subjects and patients at thrombotic risk. Thromb Haemost. 2005;93:1128-1136.

6. Brass LF. Thrombin and platelet activation. Chest. 2003;124:18S-25S.

7. Coughlin SR. Protease-activated receptors in hemostasis, thrombosis and vascular biology. $\mathrm{J}$ Thromb Haemost. 2005;3:1800-1814.

8. Offermanns S. Activation of platelet function through $\mathrm{G}$ protein-coupled receptors. Circ Res. 2006;99:1293-1304.

9. Heemskerk JW, Bevers EM, Lindhout T. Platelet activation and blood coagulation. Thromb Haemost. 2002;88:186-193.

10. Béguin S, Kumar R. Thrombin, fibrin and platelets, a resonance loop in which von Willebrand factor is a necessary link. Thromb Haemost. 1997;78:590-594.

11. Cattaneo M, Gachet C. ADP receptors and clinical bleeding disorders. Arterioscler Thromb Vasc Biol. 1999;19:2281-2285.

12. Andre P, Delaney SM, LaRocca T, Vincent D, DeGuzman F, Jurek M, Koller B, Phillips DR, Conley PB. P2Y ${ }_{12}$ regulates platelet adhesion/activation, thrombus growth, and thrombus stability in injured arteries. J Clin Invest. 2003;112:398-406.

13. Kim S, Foster C, Lecchi A, Quinton TM, Prosser DM, Jin J, Cattaneo M, Kunapuli SP. Protease-activated receptors 1 and 4 do not stimulate $\mathrm{Gi}$ signaling pathways in the absence of secreted $A D P$ and cause human platelet aggregation independently of Gi signaling. Blood. 2002;99:3629-3636.

14. Jin J, Kunapuli SP. Coactivation of two different $G$ protein-coupled receptors is essential for ADP-induced platelet aggregation. Proc Natl Acad Sci USA. 1998;95:8070-8074.

15. Gachet C, Hechler B, Léon C, Vial C, Leray C, Ohlmann P, Cazenave JP. Activation of ADP receptors and platelet function. Thromb Haemost. 1997;78:271-275.

16. Hechler B, Zhang Y, Eckly A, Cazenave JP, Gachet C, Ravid K. Lineage-specific overexpression of the $\mathrm{P}_{2} \mathrm{Y}_{1}$ receptor induces platelet hyper-reactivity in transgenic mice. $\mathrm{J}$ Thromb Haemost. 2003;1:155-163.

17. Jantzen HM, Milstone DS, Gousset L, Conley PB, Mortensen RM. Impaired activation of murine platelets lacking Gai2. J Clin Invest. 2001;108:477-483.

18. Jackson SP, Yap CL, Anderson KE. Phosphoinositide 3-kinases and the regulation of platelet function. Biochem Soc Trans. 2004;32:387-392.

19. Hirsch E, Bosco O, Tropel P, Laffargue M, Calvez R, Altruda F, Wymann M, Montrucchio G. Resistance to thromboembolism in PI3K $\gamma$-deficient mice. FASEB J. 2001;15:2019-2021.

20. Cosemans JM, Munnix IC, Wetzker R, Heller R, Jackson SP, Heemskerk JW. Continuous signaling via PI3K isoforms $\beta$ and $\gamma$ is required for platelet ADP receptor function in dynamic thrombus stabilization. Blood. 2006;108:3045-3052. 
21. Jackson SP, Schoenwaelder SM, Goncalves I, Nesbitt WS, Yap CL, Wright CE, Kenche V, Anderson KE, Dopheide SM, Yuan Y, Sturgeon SA, Prabaharan H, Thompson PE, Smith GD, Shepherd PR, Daniele N, Kulkarni S, Abbott B, Saylik D, Jones C, Lu L, Giuliano S, Hughan SC, Angus JA, Robertson AD, Salem HH. PI 3-kinase p110ß: a new target for antithrombotic therapy. Nat Med. 2005;11:507-514.

22. Léon C, Ravanat C, Freund M, Cazenave JP, Gachet C. Differential involvement of the P2Y, and $\mathrm{P}_{2} \mathrm{Y}_{12}$ receptors in platelet procoagulant activity. Arterioscler Thromb Vasc Biol. 2003;23:1941-1947.

23. Dorsam RT, Tuluc M, Kunapuli SP. Role of protease-activated and ADP receptor subtypes in thrombin generation on human platelets. J Thromb Haemost. 2004;2:804-812.

24. Sargeant $\mathrm{P}$, Farndale RW, Sage SO. ADP- and thapsigargin-evoked $\mathrm{Ca}^{2+}$ entry and proteintyrosine phosphorylation are inhibited by the tyrosine kinase inhibitors genistein and methyl2,5-dihydroxycinnamate in fura-2-loaded human platelets. J Biol Chem. 1993;268:1815118156.

25. Hardy AR, Jones ML, Mundell SJ, Poole AW. Reciprocal cross-talk between P2Y $Y_{1}$ and $P 2 Y_{12}$ receptors at the level of calcium signaling in human platelets. Blood. 2004;104:1745-1752.

26. Cavallini L, Coassin M, Borean A, Alexandre A. Prostacyclin and sodium nitroprusside inhibit the activity of the platelet inositol 1,4,5-trisphosphate receptor and promote its phosphorylation. J Biol Chem. 1996;271:5545-5551.

27. Keularts IM, van Gorp RM, Feijge MA, Vuist WM, Heemskerk JW. $\alpha_{2 A}$-adrenergic receptor stimulation potentiates calcium release in platelets by modulating cAMP levels. J Biol Chem. 2000;275:1763-1772.

28. den Dekker E, Gorter G, Heemskerk JW, Akkerman JW. Development of platelet inhibition by cAMP during megakaryocytopoiesis. J Biol Chem. 2002;277:29321-29329.

29. van Gorp RM, Feijge MA, Vuist WM, Rook MB, Heemskerk JW. Irregular spiking in free calcium concentration in single, human platelets. Regulation by modulation of the inositol trisphosphate receptors. Eur J Biochem. 2002;269:1543-1552.

30. Fischer L, Gukovskaya AS, Young SH, Gukovsky I, Lugea A, Buechler P, Penninger JM, Friess $\mathrm{H}$, Pandol SJ. Phosphatidylinositol 3-kinase regulates $\mathrm{Ca}^{2+}$ signaling in pancreatic acinar cells through inhibition of sarco(endo)plasmic reticulum $\mathrm{Ca}^{2+}$-ATPase. Am J Physiol Gastrointest Liver Physiol. 2004;287:G1200-1212.

31. Scharenberg AM, Kinet JP. Ptdlns-3,4,5-P3: a regulatory nexus between tyrosine kinases and sustained calcium signals. Cell. 1998;94:5-8.

32. Lian L, Wang Y, Draznin J, Eslin D, Bennett JS, Poncz M, Wu D, Abrams CS. The relative role of PLC $\beta$ and PI3K $\gamma$ in platelet activation. Blood. 2005;106:110-117.

33. Kim S, Jin J, Kunapuli SP. Akt activation in platelets depends on Gi signaling pathways. J Biol Chem. 2004;279:4186-4195.

34. Soulet C, Sauzenau V, Plantavid M, Herbert JM, Pacaud P, Payrastre B, Savi P. Gidependent and -independent mechanisms downstream of the P2Y ${ }_{12}$ ADP-receptor. J Thromb Haemost. 2004;2:135-146.

35. Offermanns S, Toombs CF, Hu YH, Simon MI. Defective platelet activation in Gaq-deficient mice. Nature. 1997;389:183-186.

36. Storey RF, Sanderson HM, White AE, May JA, Cameron KE, Heptinstall S. The central role of the P2T receptor in amplification of human platelet activation, secretion and procoagulant activity. Br J Haematol. 2000;110:925-934.

37. Tolloczko B, Turkewitsch P, Al-Chalabi M, Martin JG. LY-294002 [2-(4-morpholinyl)-8-phenyl$4 \mathrm{H}$-1-benzopyran-4-one] affects calcium signaling in airway smooth muscle cells independently of phosphoinositide 3-kinase inhibition. J Pharmacol Exp Ther. 2004;311:787793.

38. Kim S, Jin J, Kunapuli SP. Relative contribution of G-protein-coupled pathways to proteaseactivated receptor-mediated Akt phosphorylation in platelets. Blood. 2006;107:947-954. 
39. Banno Y, Nakashima S, Ohzawa M, Nozawa Y. Differential translocation of phospholipase C isozymes to integrin-mediated cytoskeletal complexes in thrombin-stimulated human platelets. J Biol Chem. 1996;271:14989-14994.

40. Sage SO, Yamoah EH, Heemskerk JW. The roles of $P 2 X_{1}$ and $P 2 T_{A C}$ receptors in ADPevoked calcium signaling in human platelets. Cell Calcium. 2000;28:119-126.

41. Hirsch E, Katanaev VL, Garlanda C, Azzolino O, Pirola L, Silengo L, Sozzani S, Mantovani A, Altruda F, Wymann MP. Central role for G protein-coupled phosphoinositide 3-kinase $\gamma$ in inflammation. Science. 2000;287:1049-1053.

42. Condliffe AM, Davidson K, Anderson KE, Ellson CD, Crabbe T, Okkenhaug K, Vanhaesebroeck B, Turner M, Webb L, Wymann MP, Hirsch E, Ruckle T, Camps M, Rommel C, Jackson SP, Chilvers ER, Stephens LR, Hawkins PT. Sequential activation of class IB and class IA PI3K is important for the primed respiratory burst of human but not murine neutrophils. Blood. 2005;106:1432-1440.

43. Feijge MA, van Pampus EC, Lacabaratz-Porret C, Hamulyak K, Lévy-Toledano S, Enouf J, Heemskerk JW. Inter-individual variability in $\mathrm{Ca}^{2+}$ signaling in platelets from healthy volunteers: effects of aspirin and relationship with expression of endomembrane $\mathrm{Ca}^{2+}$ ATPases. Br J Haematol. 1998;102:850-859.

44. Heemskerk JW, Feijge MA, Henneman L, Rosing J, Hemker HC. The $\mathrm{Ca}^{2+}$-mobilizing potency of $\alpha$-thrombin and thrombin-receptor-activating peptide on human platelets - concentration and time effects of thrombin-induced $\mathrm{Ca}^{2+}$ signaling. Eur J Biochem. 1997;249:547-555.

45. Goncalves I, Hughan SC, Schoenwaelder SM, Yap CL, Yuan Y, Jackson SP. Integrin allbß33dependent calcium signals regulate platelet-fibrinogen interactions under flow. Involvement of phospholipase C $\gamma 2$. J Biol Chem. 2003;278:34812-34822.

46. Freire MM, Mignaco JA, de Carvalho-Alves PC, Barrabin H, Scofano HM. 3-Omethylfluorescein phosphate as a fluorescent substrate for plasma membrane $\mathrm{Ca}^{2+}$-ATPase. Biochim Biophys Acta. 2002;1553:238-248.

47. Vanschoonbeek K, Feijge MA, van Kampen RJ, Kenis H, Hemker HC, Giesen PL, Heemskerk JW. Initiating and potentiating role of platelets in tissue factor-induced thrombin generation in the presence of plasma: subject-dependent variation in thrombogram characteristics. J Thromb Haemost. 2004;2:476-484. 


\section{Role of integrin $\alpha$ llb $\beta 3$ outside-in signaling in the development of platelet procoagulant activity and thrombin generation}

Paola E.J. van der Meijden, Marion A.H. Feijge, Karen Gilio, Sandra Cauwenberghs,

Karly Hamulyák and Johan W.M. Heemskerk

Submitted for publication 


\section{Abstract}

Integrin $\alpha \mathrm{llb} \beta 3$ mediates adhesion and aggregation of platelets via binding of fibrinogen. Integrin $\alpha$ llb $\beta 3$ inhibitors not only affect these responses, but also suppress the ability of platelets to support thrombin generation. We hypothesized that $\alpha \operatorname{lb} \beta 3$ antagonists affect platelet procoagulant activity through displacement of its main ligand, fibrinogen, with as a result abrogated outside-in signaling by the integrin. The structurally different integrin blockers, abciximab, eptifibatide and tirofiban reduced and delayed tissue factor-induced generation of thrombin in plasma at a similar extent, provided that platelets were present. This reduction was accompanied by a potent decrease in phosphatidylserine exposure on the platelet surface. Isolated platelets stimulated with thrombin and convulxin responded by binding of fibrin(ogen), a prolonged rise in cytosolic $\mathrm{Ca}^{2+}$ and surface exposure of phosphatidylserine. All these responses were suppressed by $\alpha$ llb $\beta 3$ inhibition and they were also greatly reduced in platelets from a patient with Glanzmann's thrombasthenia, lacking $\alpha$ llb $\beta 3$. Stimulation of outside-in integrin signaling in platelets spread on fibrinogen potentiated the thrombin-induced $\mathrm{Ca}^{2+}$ rises and increased the exposure of PS. Also this response was essentially absent in Glanzmann platelets. Inhibitor studies showed that phosphoinositide 3-kinase was involved in the platelet procoagulant response, likely in part via $\mathrm{P}_{2} \mathrm{Y}_{12}$ receptor signaling. Together, these results indicate that outside-in signaling by fibrin(ogen)-occupied integrin $\alpha$ llb $\beta 3$ contributes to PS exposure by maintaining a high $\mathrm{Ca}^{2+}$ signal in stimulated platelets.

\section{Introduction}

The major platelet integrin, $\alpha$ llb $\beta 3$ (glycoprotein Ilb/llla), plays a key role in the adhesion and aggregation of platelets. Platelet activation by agonists like ADP, thrombin and collagen results in a conformational change of $\alpha$ llb $\beta 3$, which increases its affinity for ligands such as fibrinogen and von Willebrand factor. This integrin inside-out signaling relies on association of the $\beta 3$-chain with the actin-binding proteins talin and kindlin- $3,{ }^{1,2}$ and is a premise for platelet-platelet interactions and hence aggregate formation. ${ }^{3,4}$ Conversely, fibrinogen binding, particularly under conditions favoring $\alpha$ llb $\beta 3$ clustering, induces outside-in signaling of the integrin itself, through a pathway involving complex formation and activation of the protein tyrosine kinases, Src, Syk and FAK ${ }^{5,6}$ In synergism with $A D P$-induced signaling via $\mathrm{P}_{2} \mathrm{Y}_{12}$ receptors, outside-in signaling also leads to activation of phosphoinositide 3-kinase (PI3-K) and to an increased intracellular $\mathrm{Ca}^{2+}$ level in a not well understood way. ${ }^{7}$ The result of integrin $\alpha$ llb $\beta 3$ activation and signaling is cytoskeletal reorganization, granule secretion and lamellipod formation, with as physiological consequence, spreading of platelets at an integrin-adhesive surface and contraction of platelets within a clot. ${ }^{8}$ Recently, it was described that $\alpha$ llb $\beta 3$ outside-in signaling also leads to continuous shedding of microparticles from both suspended and spreading platelets. $^{9}$

In addition to forming aggregates, platelets have a procoagulant role in supporting thrombin generation and coagulation. ${ }^{10,11}$ Previous studies have shown that integrin $\alpha$ llb $\beta 3$ antagonists not only inhibit platelet aggregation but also thrombin generation and 
procoagulant activity. ${ }^{12-15}$ Several mechanisms have been proposed to be responsible for this anticoagulant effect of integrin $\alpha$ llb $\beta 3$ blockade. These include: inhibition of microparticle formation, ${ }^{12,16,17}$ displacement of binding of prothrombin to $\alpha \operatorname{llb} \beta 3,{ }^{18}$ reduced binding of factor $\mathrm{V}(\mathrm{a})$ to platelets, ${ }^{19,20}$ and a diminishing effect on platelet activation and surface exposure of procoagulant phosphatidylserine (PS). ${ }^{19,20}$ However, several papers demonstrate that integrin $\alpha$ llb $\beta 3$ inhibitors, at concentrations that completely block platelet aggregation, show distinct and even opposing effects on platelet procoagulant activity. ${ }^{17,21}$ Furthermore, recent observations indicate that the activation of $\alpha$ llb $\beta 3$ reverses in platelets under coagulant conditions. ${ }^{22}$ This raises the question whether and how the $\alpha \mathrm{llb} \beta 3$ inhibitors interact with platelets to modulate their coagulant activity.

Here we hypothesized that $\alpha \operatorname{llb} \beta 3$ antagonists affect platelet procoagulant activity through displacement of its main ligand, fibrinogen, with as a result abrogated outside-in signaling by the integrin. Procoagulant activity under thrombin-generating conditions was assessed from the ability of platelets to expose PS. As elevation in cytosolic $\mathrm{Ca}^{2+}$ is a key trigger for PS exposure, ${ }^{23}$ this platelet response was also studied. The results point to a hitherto unrecognized signaling role of integrin $\alpha$ llb $\beta 3$ towards procoagulant activity, which is dependent on ligandation with fibrinogen or fibrin.

\section{Materials and methods}

\section{Materials}

Human $\alpha$-thrombin came from Enzyme Research Laboratories (Swansea, UK). Fura-2 and Fluo-4 acetoxymethyl esters were from Molecular Probes (Leiden, NL); recombinant human tissue factor from Dade Behring (Marburg, Germany); and human thrombin calibrator from Thrombinoscope (Maastricht, NL). Apyrase, bovine serum albumin (BSA), human and bovine fibrinogen (fraction 1, type III) and wortmannin were from Sigma (St. Louis, MO, USA). Cangrelor (AR-C69931MX, AR-C) was kindly provided by The Medicine Company (Parsippany, NJ, USA). Fluorescent thrombin substrate, Z-Gly-GlyArg aminomethyl coumarin (Z-GGR-AMC) and PAR1 peptide SFLLRN were from Bachem (Bubendorf, Switzerland). Ancrod came from NIBSC (Hertfordshire, UK); fluorescein isothiocyanate (FITC)-labeled annexin A5 from PharmaTarget (Maastricht, $\mathrm{NL}$ ); FITC-labeled mAb against platelet-bound human fibrinogen from WAK Chemie Medical (Steinbach, Germany). Procoagulant phospholipid vesicles (PS : phosphatidyl choline : phosphatidyl ethanolamine $1: 3: 1 ; \mathrm{mol} / \mathrm{mol} / \mathrm{mol}$ ) were prepared, as described. ${ }^{24}$ Convulxin was purified to homogeneity from the venom of Crotalus durissus terrificus (Latoxan, France). ${ }^{25}$ Abciximab (reopro) was from Centocor (Leiden, NL); tirofiban (aggrastat) from Merck (Haarlem, NL); and eptifibatide (integrilin) from GlaxoSmithKline (Zeist, NL). 


\section{Platelet preparation and isolation}

Blood was taken from healthy volunteers and collected into $1 / 10$ volume of $129 \mathrm{mM}$ trisodium citrate. Blood was also taken from a patient with Glanzmann's thrombasthenia, with known deficiency in integrin $\alpha$ llb $\beta 3 .{ }^{26} \mathrm{PRP}$ was obtained by 15 min centrifuging at $240 \mathrm{~g}$. Platelet-free plasma (PFP) was obtained by centrifuging twice at $2630 \mathrm{~g}$ for 10 min. Platelet count in PRP was determined with a thrombocounter (Coulter Electronics, Luton, UK) and normalized with autologous PFP. To prepare washed platelets, blood was collected into $1 / 6$ volume of acid-citrate glucose solution (ACD, $80 \mathrm{mM}$ trisodium citrate, $52 \mathrm{mM}$ citric acid and $180 \mathrm{mM}$ glucose).

Human citrate-anticoagulated plasma was treated with ancrod $(1.3 \mathrm{IU} / \mathrm{mL})$ to achieve partial depletion of fibrinogen. Remaining fibrinogen content in the plasma was approximately $0.5 \mathrm{mg} / \mathrm{mL}$.

\section{Thrombin generation measurements}

Normalized PRP $\left(1.5 \times 10^{8}\right.$ platelets $\left./ \mathrm{mL}\right)$ or PFP supplemented with phospholipid vesicles $(10 \mu \mathrm{M})$ were preincubated with indicated inhibitors; platelets in PRP were pre-activated as required. Thrombin generation was initiated with tissue factor $/ \mathrm{CaCl}_{2}$ and measured at $37^{\circ} \mathrm{C}$ according to the thrombogram method, as described previously. ${ }^{13}$ Briefly, plasma samples (4 volumes) were pipetted into a polystyrene 96-wells plate (Immulon 2HB, Dynex Technologies), already containing 1 volume of buffer A (20 mM Hepes, $140 \mathrm{mM}$ $\mathrm{NaCl}, 5 \mathrm{mg} / \mathrm{mL}$ BSA and $6 \mathrm{pM}$ tissue factor). Coagulation was started by adding 1 volume of buffer B (2.5 mM Z-GGR-AMC, $20 \mathrm{mM} \mathrm{Hepes,} 100 \mathrm{mM} \mathrm{CaCl}_{2}$ and $60 \mathrm{mg} / \mathrm{mL}$ BSA). Fluorescence accumulation was measured with a Fluoroskan Ascent well-plate reader, equipped with Thrombinoscope software.

\section{Flow cytometry}

Washed platelets $\left(1.0 \times 10^{8}\right.$ platelets $\left./ \mathrm{mL}\right)$ were resuspended in buffer or ancrod-treated citrate plasma. ${ }^{27}$ Platelets were preincubated with inhibitors, and activated as required. For experiments with plasma, coagulation was triggered with tissue factor $(2 \mathrm{pM})$ and $\mathrm{CaCl}_{2}(16.6 \mathrm{mM})$. For experiments with platelets in Hepes buffer, activation was with PAR1 agonist SFLLRN $(15 \mu \mathrm{M})$ or thrombin $(10 \mathrm{nM})$ in combination with convulxin (50 $\mathrm{ng} / \mathrm{mL}$ ). After $15 \mathrm{~min}$ of activation, platelet surface characteristics were determined by flow cytometry using FITC-labeled annexin A5 or FITC-labeled mAb against plateletbound human fibrinogen.

\section{Cytosolic $\mathrm{Ca}^{2+}$ measurements}

To evaluate changes in cytosolic free $\mathrm{Ca}^{2+}$, PRP was incubated with Fura-2 acetoxymethyl ester $(2.5 \mu \mathrm{M})$ at $37^{\circ} \mathrm{C}$ for $45 \mathrm{~min}$, under standardized conditions. ${ }^{28}$ Fura2-loaded platelets were washed in the presence of apyrase $(0.1 \mathrm{U} / \mathrm{mL}$ ADPase), and finally resuspended in Hepes buffer $\mathrm{pH} 7.45$ (10 mM Hepes, $136 \mathrm{mM} \mathrm{NaCl}, 2.7 \mathrm{mM} \mathrm{KCl}$, $2 \mathrm{mM} \mathrm{MgCl} 2,0.1 \%$ glucose and $0.1 \% \mathrm{BSA}$ ) at a concentration of $1.0 \times 10^{8}$ platelets $/ \mathrm{mL}$. 
Before start of measurements, platelets were incubated with inhibitors or vehicle solution and $2 \mathrm{mM} \mathrm{CaCl}_{2}$. Nanomolar changes in cytosolic $\left[\mathrm{Ca}^{2+}\right]$ i were measured by ratio fluorometry at $37^{\circ} \mathrm{C} .^{29}$ Platelet suspensions were slowly stirred.

\section{Single cell activation measurements}

Glass coverslips were coated with $25 \mu \mathrm{L}$ fibrinogen solution $(1 \mathrm{mg} / \mathrm{mL})$ during $10 \mathrm{~min}$, and rinsed with saline. Washed platelets in Hepes buffer $\mathrm{pH} 7.45\left(1.0 \times 10^{8}\right.$ platelets $\left./ \mathrm{mL}\right)$ were allowed to adhere to fibrinogen-coated coverslips for $30 \mathrm{~min}$. After 5-10 min, nonadherent platelets were removed by rinsing with Hepes buffer. Platelets were pre-loaded with Fura-2, as appropriate. The adhered platelets were stimulated with thrombin (10 $\mathrm{nM})$ in Hepes buffer containing $\mathrm{CaCl}_{2}(2 \mathrm{mM})$. Phase contrast images and fluorescence ratio images, indicating cytosolic $\mathrm{Ca}^{2+}$ levels (Fura-2) or PS exposure (FITC-labeled annexin A5), were taken using a dual camera imaging system, controlled by Visitech software, as described before. ${ }^{30}$

\section{Statistics}

Significance of differences was determined with the Mann-Whitney $U$ test or the independent samples $t$ test, as appropriate, using the statistical package for social sciences (SPSS 15.0, Chicago, IL).

\section{Results}

\section{Similar effects of various integrin $\alpha$ llb $\beta 3$ inhibitors on thrombin generation in platelet-rich plasma}

Integrin $\alpha$ llb $\beta 3$ blockers were suggested to have different effects on platelet-dependent coagulation. ${ }^{17,21}$ To examine this in more detail, we compared the three integrin inhibitors that currently are in clinical use: the human/mouse chimeric monoclonal antibody fragment abciximab (also inhibiting $\alpha v \beta 3$ ), the peptide compound eptifibatide, and the non-peptide compound tirofiban. At physiological extracellular $\mathrm{Ca}^{2+}$ concentrations, these compounds inhibit SFLLRN (PAR1)-induced aggregation in PPACK-anticoagulated PRP with $\mathrm{IC}_{50}$ values of $5 \mu \mathrm{g} / \mathrm{mL}, 0.5 \mu \mathrm{g} / \mathrm{mL}$ and $0.1 \mu \mathrm{g} / \mathrm{mL}$, respectively. ${ }^{31}$ This is in accordance with the known difference in affinities of the compounds for $\alpha \mathrm{llb} \beta 33^{32} \mathrm{We}$ investigated the effect of these inhibitors on thrombin generation in PRP, triggered with tissue factor $/ \mathrm{CaCl}_{2}$. All three inhibitors suppressed and delayed the formation of thrombin to a similar (lowest) level of about $20 \mathrm{nM}$ thrombin (Fig. 1A). With all inhibitors, the effect was dose-dependent (Fig. 1B). Half-maximal reduction in thrombin peak height was achieved at approximately $2 \mu \mathrm{g} / \mathrm{mL}$ (abciximab), $1 \mu \mathrm{g} / \mathrm{mL}$ (eptifibatide) and $0.1 \mu \mathrm{g} / \mathrm{mL}$ (tirofiban). Hence, in comparison to platelet aggregation (under non-coagulant conditions), the integrin inhibitors did not completely suppress thrombin generation, and slightly higher concentrations were needed for a half-maximal effect. To determine whether this inhibiting effect is specific and solely 
A
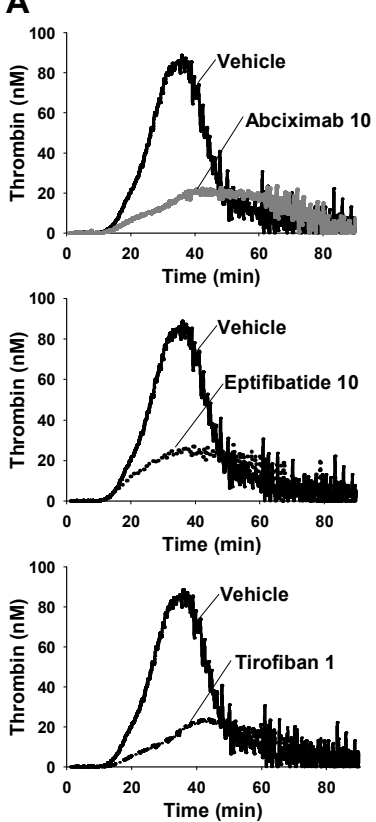

B
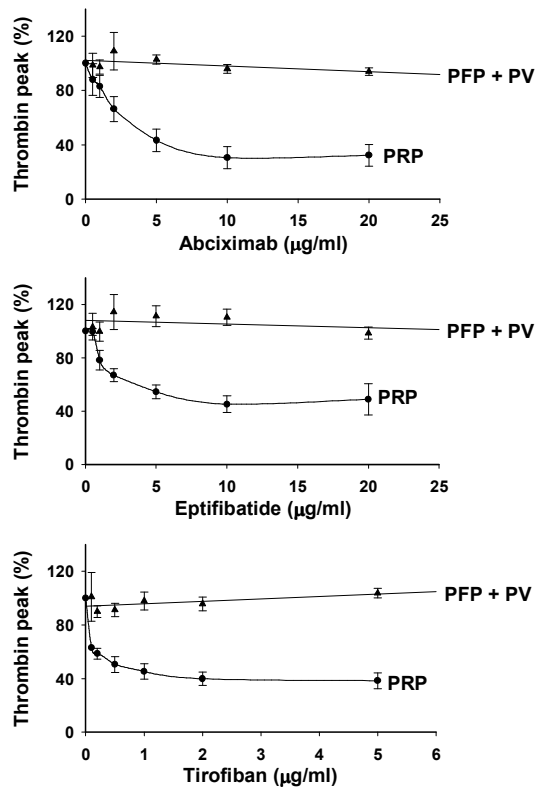

Figure 1. Antagonism of $\alpha$ llb $\beta 3$ suppresses thrombin generation in the presence of platelets. Human PRP $\left(1.0 \times 10^{8}\right.$ platelets $/ \mathrm{mL}$, f.c.) or PFP supplemented with phospholipid vesicles (PV 10 $\mu \mathrm{M}$, f.c.) was preincubated with vehicle, abciximab $(0.5-20 \mu \mathrm{g} / \mathrm{mL})$, eptifibatide $(0.5-20 \mu \mathrm{g} / \mathrm{mL})$ or tirofiban $(0.1-5 \mu \mathrm{g} / \mathrm{mL})$ for $20 \mathrm{~min}$. Thrombin generation was measured after triggering with tissue factor $(1 \mathrm{pM})$ and $\mathrm{CaCl}_{2}(16.6 \mathrm{mM})$. (A) Representative thrombin generation traces with PRP, showing the comparable inhibitory effect of integrin blockers in the presence of platelets. (B) Dosedependent effect of integrin inhibitors on thrombin peak height. Data are relative to the control condition with vehicle (mean \pm SEM, $n=3-5$ ).

dependent on platelets, thrombin generation was measured in plasma in which phospholipids vesicles provided the procoagulant surface. As shown in Fig. 1B, none of the $\alpha$ llb $\beta 3$ inhibitors did influence thrombin peak levels, even not the highest doses applied, thus demonstrating that they do not affect the coagulation process as such.

\section{Fibrinogen binding to integrin $\alpha$ llb $\beta 3$ leads to increased PS exposure}

It has been reported that particularly antibody-based $\alpha$ llb $\beta 3$ inhibitors suppress platelet PS exposure in response to thrombin with/without collagen. ${ }^{19-21,33}$ Flow cytometry was applied to determine how the reducing effect of $\alpha$ llb $\beta 3$ inhibitors on in situ thrombin generation is related to PS exposure of platelets. For practical reasons, citrateanticoagulated plasma was treated with the snake venom ancrod, resulting in partial defibrination with a fibrinogen level below the threshold for macroscopic fibrin clot formation $(<1 \mathrm{mg} / \mathrm{mL})$. Control experiments where this plasma was reconstituted with platelets indicated that the integrin blockers still caused normal suppression of tissue factor $/ \mathrm{CaCl}_{2}$-induced thrombin generation, in spite of the fact that no massive clots were 
A In situ thrombin

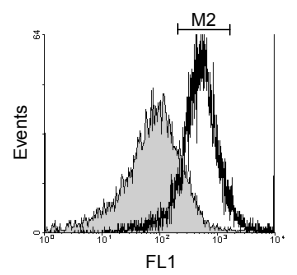

Anti-human fibrinogen

B Thrombin + convulxin

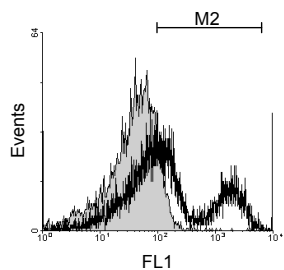

Anti-human fibrinogen

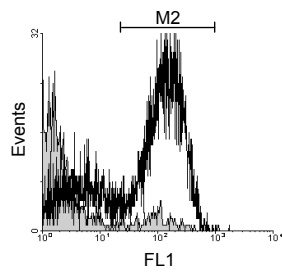

Annexin A5

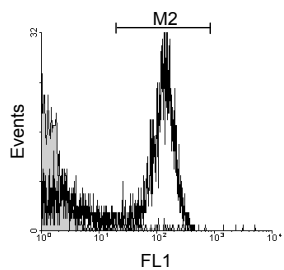

Annexin A5
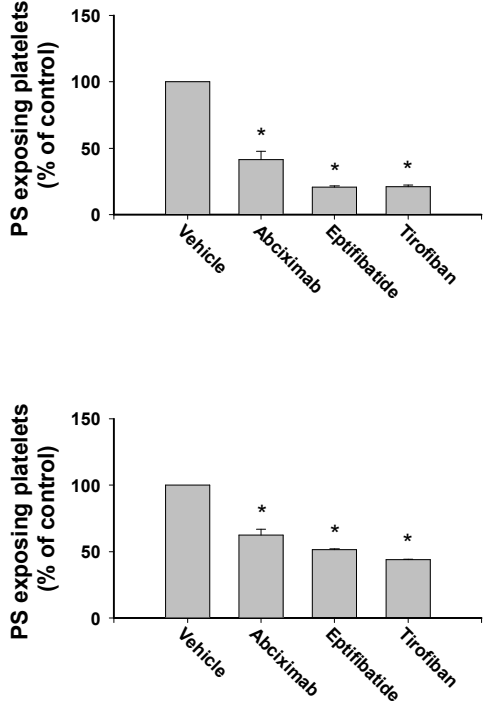

Figure 2. Antagonism of $\alpha$ llb $\beta 3$ reduces PS exposure of platelets activated in the presence or absence of plasma. Platelets reconstituted with defibrinated plasma or platelets in Hepes buffer $\mathrm{pH}$ 7.45 were preincubated with vehicle, abciximab $(10 \mu \mathrm{g} / \mathrm{mL})$, eptifibatide $(10 \mu \mathrm{g} / \mathrm{mL})$ or tirofiban $(1$ $\mu \mathrm{g} / \mathrm{mL}$ ). (A) The plasma was triggered with tissue factor and $\mathrm{CaCl}_{2}$ for $15 \mathrm{~min}$ for in situ thrombin generation. Flow cytometry was used to determine: (i) platelet binding of fibrinogen with FITC-antihuman fibrinogen, and (ii) platelet exposure of PS with FITC-labeled annexin A5. (B) Platelets in Hepes buffer were stimulated with thrombin $(10 \mathrm{nM})+$ convulxin $(50 \mathrm{ng} / \mathrm{mL})$ in the presence of $\mathrm{CaCl}_{2}(2 \mathrm{mM})$ for $15 \mathrm{~min}$. Flow cytometry was used as above. Shown are representative histograms of annexin A5 and anti-fibrinogen fluorescence (grey: non-activated, black: activated platelets); M2 indicates the population positively stained. Bars indicate percentages of PS-exposing platelets relative to the vehicle condition. Data are mean \pm SEM $(n=3-6) ;{ }^{*} p<0.05$ vs. vehicle.

formed (data not shown). At $15 \mathrm{~min}$ after addition of tissue factor $/ \mathrm{CaCl}_{2}$, binding of fibrin(ogen) to platelets was determined using a fluorescent-labeled $m A b$ against platelet-bound fibrinogen (which also detects fibrin). Increased fibrin(ogen) binding was observed in the whole platelet population (Fig. 2A). Labeling with FITC-annexin A5 showed that the majority of platelets stained positively and hence exposed PS. Preincubation of the reconstituted PRP with abciximab $(10 \mu \mathrm{g} / \mathrm{mL})$ decreased the amount of PS-exposing platelets to $41 \pm 6.3 \%$ of control (Fig. 2A). Eptifibatide $(10 \mu \mathrm{g} / \mathrm{mL}$ ) and tirofiban $(1 \mu \mathrm{g} / \mathrm{mL})$ each reduced the fraction of PS-exposing platelets to about $20 \%$ of control. Furthermore, $\alpha \mathrm{llb} \beta 3$ blockade reduced the binding of fibrin(ogen) to platelets to $51 \pm 3.2 \%$. Flow cytometry further indicated that the integrin blockers had a reducing, though less predominant, effect on microparticle formation (not shown), but this was not further investigated. Together, these results suggest that the suppressive effect of integrin inhibitors on thrombin generation was particularly due to reduced PS exposure by platelets. This by implication points to a reducing effect of integrin inhibitors on the activation process of platelets to PS exposure. 
In suspensions of washed platelets, PS exposure can be achieved by stimulation with a combination of thrombin and collagen receptor agonists. ${ }^{23}$ Suspended platelets were therefore stimulated with thrombin (activating PAR1 and PAR4) and convulxin (stimulating the GPVI receptor for collagen) in the presence of $\mathrm{CaCl}_{2}$. After $15 \mathrm{~min}$ of activation, this resulted in a fraction of $35 \pm 2.9 \%$ PS-exposing platelets (Fig. 2B). Staining with anti-fibrinogen $\mathrm{mAb}$ indicated that the majority of the platelets bound fibrin(ogen), which was secreted by the platelets themselves. Also in this case, platelet pretreatment with integrin inhibitors resulted in a markedly reduced fraction of PS-exposing platelets, reaching $65 \%$ (abciximab) to $50 \%$ (eptifibatide or tirofiban) of the control condition (Fig. 2B).

These results suggest that the activation of platelets leads to fibrinogen secretion which, by binding to integrin $\alpha \mathrm{llb} \beta 3$, induces outside-in signaling towards enhanced PS exposure. This scheme was tested by determining the effect of fibrinogen addition on PS exposure to platelets that were stimulated with thrombin and collagen receptor agonists. To prevent fibrinogen degradation and clot formation, the cells were incubated with the PAR1 agonist SFLLRN (instead of thrombin) plus convulxin. As indicated in Fig. 3, addition of purified bovine fibrinogen caused a dose-dependent, stimulating effect on PS exposure, reaching a fraction of $>70 \%$ PS-exposing platelets at the highest dose tested ( $2 \mathrm{mg} / \mathrm{mL}$ ). Importantly, pretreatment with tirofiban (Fig. 3) or other integrin inhibitors (not shown) reversed the stimulating effect of fibrinogen on PS exposure. Comparable results were obtained by addition of purified human fibrinogen; in this case, fractions of PSexposing platelets dose-dependently increased to $146 \pm 19 \%(0.1 \mathrm{mg}$ fibrinogen $/ \mathrm{mL})$ and $193 \pm 14 \%$ ( $2 \mathrm{mg}$ fibrinogen $/ \mathrm{mL}, \mathrm{n}=3$ ) of the control condition. Accordingly, fibrinogen interaction with $\alpha \mathrm{llb} \beta 3$ appears to result in enhancement of PS exposure at the platelet surface.

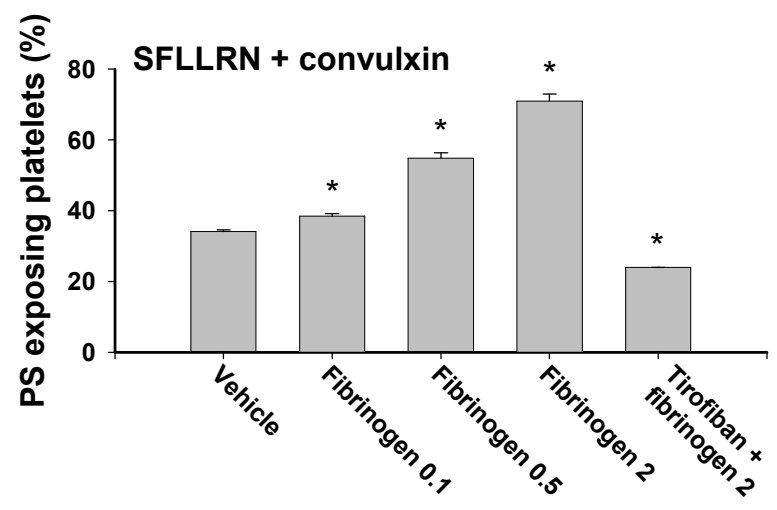

Figure 3. Fibrinogen stimulates PS exposure of activated platelets. Washed platelets in Hepes buffer $\mathrm{pH} 7.45$ were incubated with vehicle, tirofiban $(1 \mu \mathrm{g} / \mathrm{mL})$ and/or fibrinogen $(0.1-2 \mathrm{mg} / \mathrm{mL})$ for $20 \mathrm{~min}$ at $37^{\circ} \mathrm{C}$. Platelets were then activated with SFLLRN $(15 \mu \mathrm{M})+$ convulxin $(50 \mathrm{ng} / \mathrm{mL})$ in the presence of $\mathrm{CaCl}_{2}(2 \mathrm{mM})$. After $15 \mathrm{~min}$, FITC-labeled annexin A5 was added, and fractions of PSexposing platelets were determined by flow cytometry. Data are means $\pm S E M(n=3) ;{ }^{*} p<0.05$ vs. vehicle. 


\section{Integrin $\alpha$ llb $\beta 3$ outside-in signaling maintains high cytosolic $\mathrm{Ca}^{2+}$ levels and stimulates PS exposure}

In platelets stimulated with potent agonists, a sustained rise in cytosolic $\mathrm{Ca}^{2+}$ is required for PS exposure. ${ }^{10}$ However, various papers indicate that $\alpha$ llb $\beta 3$ blockade does not change platelet $\mathrm{Ca}^{2+}$ responses. ${ }^{20,33}$ We reasoned that $\alpha$ llb $\beta 3$ signaling may contribute to prolongation rather than to initialization of the platelet $\mathrm{Ca}^{2+}$ signal. To study this, suspensions of Fura-2 loaded platelets were stimulated with thrombin and convulxin, and levels of cytosolic $\mathrm{Ca}^{2+}$ were monitored for up to $15 \mathrm{~min}$ by ratio fluorometry. Note that this method relies on ratio measurements of fluorescence at $340 \mathrm{~nm}$ and $380 \mathrm{~nm}$ excitation. Hence, it is not affected by changes in the absolute amount of fluorescence, e.g. due to aggregation of platelets or bleaching of fluorescence. In the absence of inhibitors, thrombin/convulxin-stimulated platelets showed a strong initial increase in cytosolic $\mathrm{Ca}^{2+}$, which was followed after $3 \mathrm{~min}$ by a sustained high $\mathrm{Ca}^{2+}$ level,

A

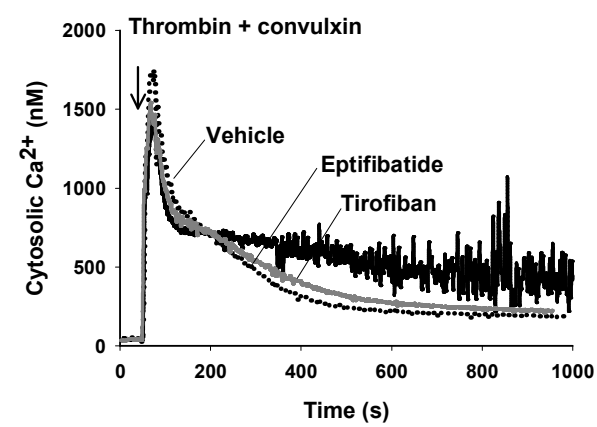

C

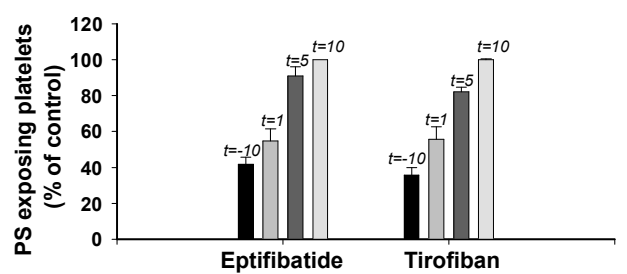

B
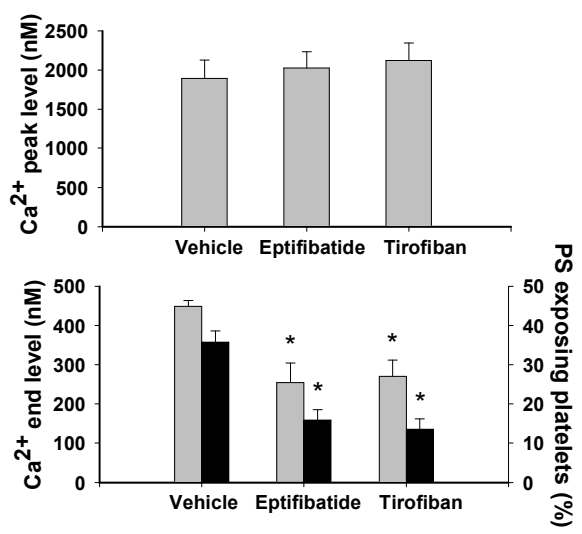

Figure 4. Integrin allb $\beta 3$-enhanced $\mathrm{Ca}^{2+}$ signaling increases PS exposure in activated platelets. Fura-2 loaded platelets were preincubated with vehicle, eptifibatide $(10 \mu \mathrm{g} / \mathrm{mL})$ or tirofiban $(1 \mu \mathrm{g} / \mathrm{mL})$, as in Fig. 2B. Platelets were activated with thrombin $(10 \mathrm{nM})+$ convulxin $(50$ $\mathrm{ng} / \mathrm{mL}$ ) in the presence of $\mathrm{CaCl}_{2}(2 \mathrm{mM})$. (A) Traces of changes in cytosolic $\mathrm{Ca}^{2+}$ in suspensions of platelets, representative for 3 or more experiments with platelets from different donors. (B) Averaged cytosolic $\mathrm{Ca}^{2+}$ peak levels and end levels $(15 \mathrm{~min})$ of suspensions of platelets. Fractions of PS-exposing platelets (black bars) were determined in 15 min samples, using flow cytometry and FITC-annexin A5 label. (C) Time effect of addition of integrin antagonist on PS exposure. Platelets in Hepes buffer $\mathrm{pH} 7.45$ were stimulated as for panel $\mathrm{B}$ at $\mathrm{t}=0$. Aliquots were treated with eptifibatide $(10 \mu \mathrm{g} / \mathrm{mL})$ or tirofiban $(1 \mu \mathrm{g} / \mathrm{mL})$, either before $(\mathrm{t}=-10 \mathrm{~min})$ or after ( $\mathrm{t}=1$ to $10 \mathrm{~min})$ stimulation with thrombin + convulxin. Fractions of PS-exposing platelets were determined in 15 min samples by flow cytometry with FITC-annexin A5. Data are relative to the control condition without antagonist. Means \pm SEM $(n=3-5) ;{ }^{*} p<0.05$ vs. vehicle. 
persisting at $450 \mathrm{nM}$ during $15 \mathrm{~min}$ (Fig. 4A). Preincubation of the platelets with eptifibatide or tirofiban did not influence the initial $\mathrm{Ca}^{2+}$ peak level (Fig. 4B). However, both inhibitors markedly reduced the late phase (3-15 $\mathrm{min}$ ) of the $\mathrm{Ca}^{2+}$ response (Fig. $4 A, B)$. After 15 min of activation, the $\mathrm{Ca}^{2+}$ level was reduced to $56 \pm 10 \%$ or $60 \pm 8 \%(\mathrm{n}=3$ 5 ) with eptifibatide or tirofiban, respectively, in comparison to the control condition. Samples of the Fura-2-loaded platelets were then used for flow cytometric detection of FITC-annexin A5 binding. Platelets that were preincubated with eptifibatide or tirofiban had a strong reduction in PS exposure (Fig. 4B).

If integrin signaling contributes to PS exposure only by prolongation of the platelet $\mathrm{Ca}^{2+}$ signal, also addition of integrin blockers after activation should decrease the number of PS-exposing platelets. This was indeed observed (Fig. 4C). Eptifibatide or tirofiban added at $1 \mathrm{~min}(\mathrm{t}=1)$ after thrombin/convulxin still caused a substantial reduction in PS-exposing platelets. Addition of the inhibitors at $5 \mathrm{~min}$ or $10 \mathrm{~min}$ after activation was progressively less effective. These results thus suggest that outside-in signaling via integrin $\alpha$ llb $\beta 3$ maintains a high $\mathrm{Ca}^{2+}$ signal in stimulated platelets, which leads to exposure of PS at the platelet surface.

To confirm these data, similar experiments were performed with platelets from a patient with Glanzmann's thrombasthenia, which lack expression of integrin $\alpha$ llb $\beta 3$. The platelets showed normal initial $\mathrm{Ca}^{2+}$ responses when stimulated with thrombin/convulxin (Fig. 5A). However, at later time points $\left(15 \mathrm{~min}\right.$ ) the cytosolic $\mathrm{Ca}^{2+}$ levels declined to below $200 \mathrm{nM}$ (Fig. 5B). Furthermore, pretreatment of Glanzmann platelets with tirofiban altered neither the late $\mathrm{Ca}^{2+}$ signal nor the (low) exposure of PS.

\section{A Glanzmann patient}

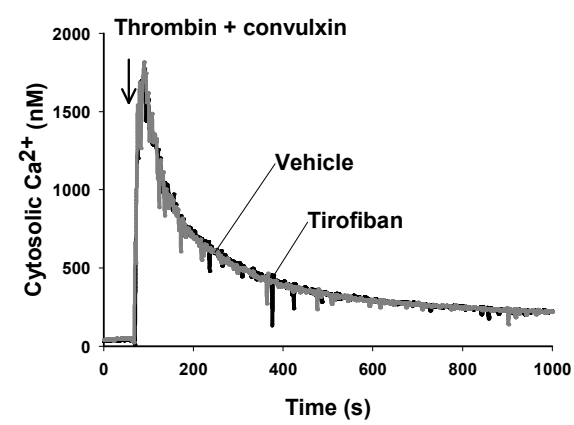

B
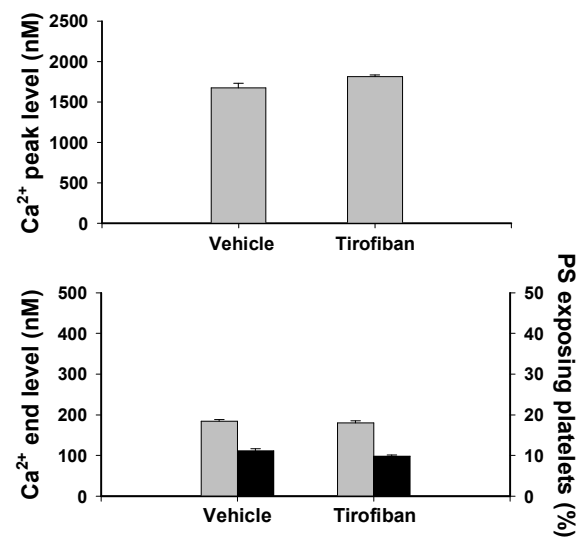

Figure 5. Reduced late $\mathrm{Ca}^{2+}$ response and reduced PS exposure in activated Glanzmann platelets. Platelets from a Glanzmann patient were loaded with Fura-2, preincubated with vehicle or tirofiban $(1 \mu \mathrm{g} / \mathrm{mL})$, and activated with thrombin and convulxin, as described for Fig. 4. (A) Traces of changes in cytosolic $\mathrm{Ca}^{2+}$ in suspensions of platelets ( 3 experiments, 1 donor). (B) Averaged cytosolic $\mathrm{Ca}^{2+}$ peak levels and end levels $(15 \mathrm{~min})$ of suspensions of platelets. Fractions of PSexposing platelets were determined in 15 min samples, by flow cytometry and FITC-annexin A5 label. Data are means \pm SEM, $(n=3,1$ donor). 
A
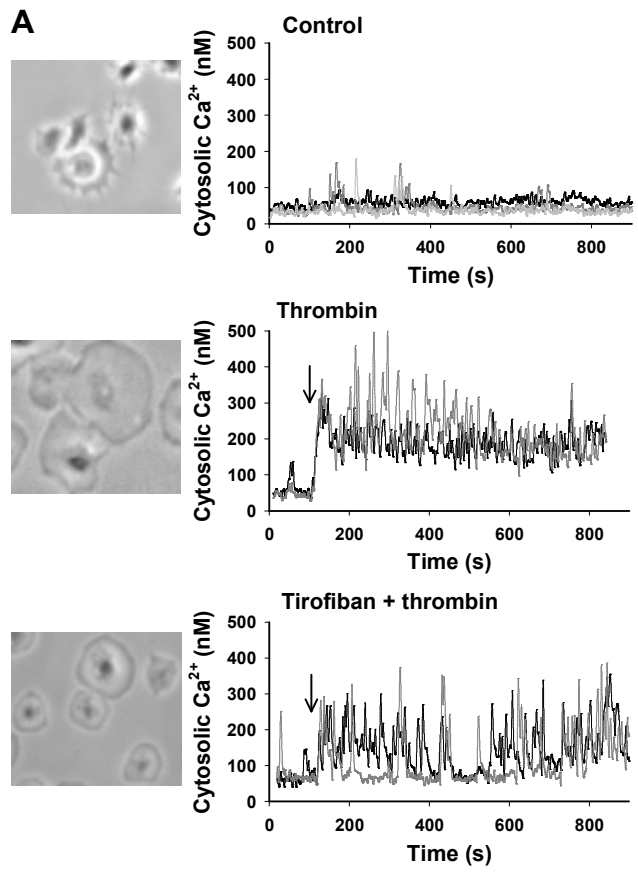

B

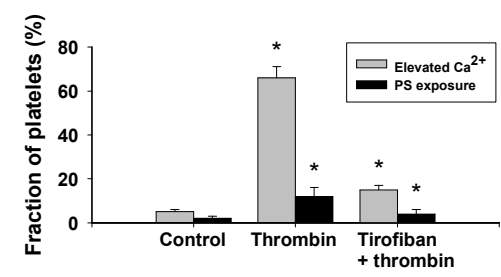

Figure 6. Platelet spreading on fibrinogen via $\alpha$ llb $\beta 3$ increases $\mathrm{Ca}^{2+}$ signaling and PS exposure in activated platelets. Fura-2 loaded platelets $\left(1.0 \times 10^{8}\right.$ platelets $\left./ \mathrm{mL}\right)$ pretreated with vehicle (control) or tirofiban $(1 \mu \mathrm{g} / \mathrm{mL}$ ) were allowed to adhere to immobilized fibrinogen for $30 \mathrm{~min}$. Cells were then stimulated with thrombin $(10 \mathrm{nM})$ for another $10 \mathrm{~min}$, as indicated. Fluorescence changes were monitored by advanced microscopy and ratio fluorometry. (A) Representative phase contrast images of platelets on fibrinogen $(35 \times 40 \mu \mathrm{m})$, and $\mathrm{Ca}^{2+}$ traces from single platelets (2 cells per condition). (B) Platelets on fibrinogen were scored for elevation in $\mathrm{Ca}^{2+}(>100 \mathrm{nM})$ and for staining with FITC-annexin A5. Figure bars give fractions of high $\mathrm{Ca}^{2+}$ and PS-exposing platelets. Data are means \pm SEM $(n=4-6) ;{ }^{*} p<0.05$ vs. control.

\section{Immobilized fibrinogen triggers $\alpha$ llb $\beta 3$ outside-in signaling and enhances PS exposure of platelets}

As another way to study the involvement of integrin signaling in PS exposure, platelets were allowed to spread on fibrinogen, which is a classical reaction directed by $\alpha$ llb $\beta 3$ outside-in signaling. ${ }^{4}$ Loading of the platelets with Fura- 2 made it possible to follow the changes in cytosolic $\mathrm{Ca}^{2+}$. Under control conditions, the platelets slowly developed filopodia and lamellipodia, which was accompanied by only incidental spiking rises in $\mathrm{Ca}^{2+}$ (Fig. 6A, upper panel). Addition of thrombin to platelets that were spreading on fibrinogen for $30 \mathrm{~min}$, stimulated the formation of lamellipodia. Thrombin addition further resulted in persistent rises in $\mathrm{Ca}^{2+}$ in most of the platelets (Fig. 6A, middle panel). Pretreatment with tirofiban reduced the thrombin-induced spreading and caused a noncontinuous but spiking $\mathrm{Ca}^{2+}$ signal in the majority of the cells (Fig. 6A, lower panel). The platelets were then stained with FITC-annexin A5 to determine PS exposure. A fraction of $12 \pm 4 \%$ platelets showed PS exposure after 30 min spreading and subsequent 
A
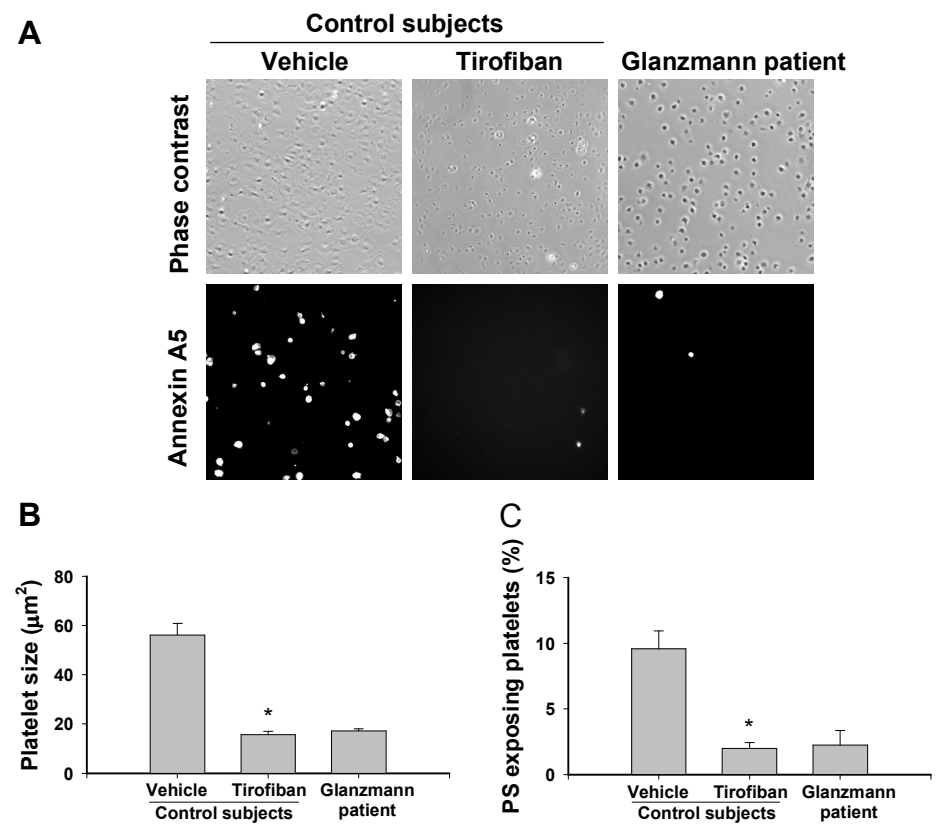

Figure 7. Involvement of $\alpha$ llb $\beta 3$ in spreading and PS exposure of activated platelets. Washed platelets $\left(1.0 \times 10^{8}\right.$ platelets $\left./ \mathrm{mL}\right)$ from control subjects or a Glanzmann patient were pretreated with vehicle or tirofiban $(1 \mu \mathrm{g} / \mathrm{mL})$ and allowed to adhere to immobilized fibrinogen for $30 \mathrm{~min}$. Platelets were then stimulated with thrombin $(10 \mathrm{nM})$ for another $10 \mathrm{~min}$. (A) Representative phase contrast $(120 \times 120 \mu \mathrm{m})$ and fluorescence images (FITC-annexin A5, 150x150 $\mu \mathrm{m})$ after $10 \mathrm{~min}$ of activation. (B) Averaged size of arbitrarily selected platelets after 10 min of activation ( $n=6$ per donor). (C) Fractions of PS-exposing platelets. Means \pm SEM ( $n=3-6) ;{ }^{*} p<0.05 v s$. vehicle.

stimulation with thrombin (Fig. 6B). In contrast, thrombin addition to non-spread platelets ( 5 min adhesion) resulted in only $2.5 \pm 0.4 \%$ of PS-exposing platelets. Furthermore, presence of tirofiban during the spreading also decreased the fraction of PS-exposing platelets to $2.0 \pm 0.4 \%$.

In a subsequent set of experiments, the extent of spreading of platelets from control subjects and a Glanzmann patient was compared for the tendency to PS exposure. While almost all platelets from control subjects spread in response to thrombin, about 10\% became annexin A5-positive (Fig. 7). Tirofiban treatment inhibited spreading and PS exposure. Platelets from the Glanzmann patient hardly spread on the fibrinogen surface, and were very low in PS exposure. Together, these data are compatible with the scenario that $\alpha \mathrm{llb} \beta 3$ outside-in signaling, induced by spreading on fibrinogen, enhanced thrombin-evoked $\mathrm{Ca}^{2+}$ rises which increase the tendency to expose PS.

A final set of experiments was designed to determine by which signaling pathway $\alpha \operatorname{lb} \beta 3$ evoked enhanced PS exposure. This was tested for platelets in partially defibrinated plasma, where thrombin was generated in situ with tissue factor. Possible involvement of PI3-K signaling was tested by pretreatment of the platelets with wortmannin. PI3-K inhibition decreased the fraction of PS-exposing platelets from $38 \%$ to $8 \%$, i.e. similar to the effect of tirofiban (Fig. 8A). As also secreted ADP can contribute to 
A

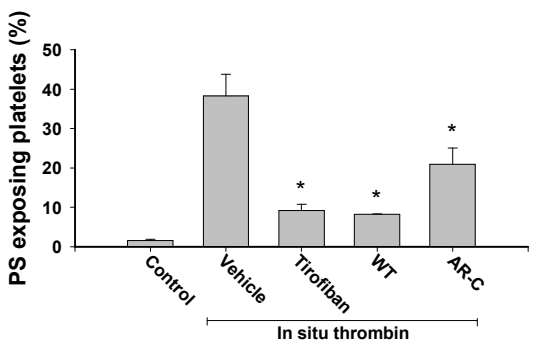

B

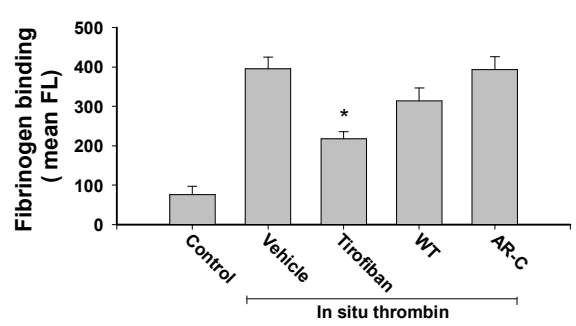

Figure 8. Roles of PI3-K and ADP in integrin allb $\beta 3$-stimulated PS exposure. Platelets reconstituted in defibrinated plasma were preincubated with vehicle, tirofiban $(1 \mu \mathrm{g} / \mathrm{mL})$, wortmannin $(200 \mathrm{nM}$ ) or cangrelor (AR-C, $10 \mu \mathrm{M})$. The plasma was triggered with tissue factor and $\mathrm{CaCl}_{2}$ for 15 min for inducing in situ thrombin generation. Flow cytometry was used to measure: (A) PS exposure FITC-labeled annexin A5; (B) binding of fibrinogen with FITC-anti-human fibrinogen mAb. Means \pm SEM $(n=3) ;{ }^{*} p<0.05$ vs. vehicle.

platelet procoagulant activity via $\mathrm{P}_{2} \mathrm{Y}_{12}$ receptors and $\mathrm{PI} 3-\mathrm{K},{ }^{27,34,35}$ the contribution of this pathway was also studied. Platelets were preincubated with the $\mathrm{P} 2 \mathrm{Y}_{12}$ blocker cangrelor (AR-C), which reduced the amount of PS-exposing platelets to $21 \%$, that is less than seen with tirofiban or wortmannin (Fig. 8A). Platelet-fibrin(ogen) binding was measured to test whether wortmannin and cangrelor affected the occupancy of $\alpha$ llb $\beta 3$ under these conditions. In contrast to tirofiban, neither of the compounds affected the fibrin(ogen) binding (Fig. 8B). Accordingly, these results indicate that the PI3-K pathway plays an important role in the integrin $\alpha$ llb $\beta 3$-mediated signaling to PS exposure, and that part of this integrin signal relies on $\mathrm{P}_{2} \mathrm{Y}_{12}$ via ADP secretion.

\section{Discussion}

This paper provides new insight into the mechanism by which integrin $\alpha$ llb $\beta 3$ antagonists affect platelet-dependent procoagulant activity and thrombin generation. Various lines of evidence demonstrate that binding of ligand, i.e. fibrin(ogen), to $\alpha$ llb $\beta 3$ via the classical pathway of outside-in signaling enhances exposure of PS on platelets that are (co)stimulated either by in-situ generated thrombin in plasma, or by purified thrombin in a plasma-free system. We show that: (i) in suspended platelets, the presence of fibrinogen stimulates long-term $\mathrm{Ca}^{2+}$ signal generation and $\mathrm{PS}$ exposure, in a way fully inhibitable by abciximab, eptifibatide and tirofiban; (ii) spreading of platelets over fibrinogen increases the thrombin-induced $\mathrm{Ca}^{2+}$ signal along with PS exposure; (iii) these fibrinogen-dependent potentiating effects are absent in platelets from a patient with Glanzmann's thrombasthenia; (iv) blockade of PI3-K antagonizes the integrin-dependent procoagulant response to a larger extent than ADP receptor blockade. Furthermore, the data show that the procoagulant effect of integrin signaling is independent of thrombin (i.e. fibrin formation), as also PAR1 (SFLLRN) and GPVI (convulxin) signaling synergizes with fibrinogen-induced integrin signaling in prolongation of the $\mathrm{Ca}^{2+}$ signal and increased exposure of PS. Together, the current results provide a mechanistic 
explanation for the earlier described (variable) effect of integrin inhibitors on the development of procoagulant activity. ${ }^{14,19-21,33}$

Earlier work demonstrated that $\alpha$ llb $\beta 3$ outside-in signaling caused shedding of microparticles from platelets even without added agonist. ${ }^{9}$ Together with the present results it seems that outside-in signaling is an ongoing event in platelets that are in continuous presence of the $\alpha \mathrm{llb} \beta 3$ ligand, fibrinogen. Likely, fibrin(ogen)-mediated outside-in signaling also contributes to the microparticle formation from platelets in clotting plasma, given the reported suppressive effect of integrin inhibitors. ${ }^{12}$ However, this was not investigated. On the other hand, it is clear that with various other agonists that stimulate platelet procoagulant activity (collagens, $\mathrm{Ca}^{2+}$ ionophores), $\mathrm{PS}$ exposure is mostly associated with microparticle formation. ${ }^{10,36,37}$

Few reports indicate that integrin inhibition or Glanzmann's thrombasthenia has no effect on the procoagulant activity of platelets stimulated with collagen alone. ${ }^{21,38}$ This does not contrast to the present concept, since GPVI stimulation causes a potent and prolonged $\mathrm{Ca}^{2+}$ signal in platelets which, by itself, is a sufficient trigger for PS exposure. $^{39}$

A number of other studies failed to detect effects of $\alpha$ llb $\beta 3$ antagonists on $\mathrm{Ca}^{2+}$ responses in collagen- and/or thrombin-stimulated platelets. ${ }^{20,21,33}$ Also a reducing effect of fibrinogen on $\mathrm{Ca}^{2+}$ signaling via store-mediated $\mathrm{Ca}^{2+}$ entry was described. ${ }^{26}$ However, in all these cases only initial $\mathrm{Ca}^{2+}$ signals were studied, which also in the current setting are not affected by $\alpha$ llb $\beta 3$ inhibition. One study reports long-term inhibition by abciximab (but curiously not by other integrin inhibitors) on collagen/thrombin-induced $\mathrm{Ca}^{2+}$ responses only under conditions of stirring. ${ }^{21}$ This clearly is compatible with the present findings, since stirring likely is increasing the ligand-integrin receptor interaction. In this context, it is worth mentioning that, under shear, $\alpha$ llb $\beta 3$ is considered to evoke $\mathrm{Ca}^{2+}$ signaling and provoke microparticle release, in a way inhibitable by abciximab. ${ }^{17,40}$

Current data with the PI3K inhibitor wortmannin indicated that this pathway, known to be triggered by $\alpha \mathrm{llb} \beta 3$ signaling, ${ }^{6}$ is implicated in the generation of platelet procoagulant activity. A feasible mechanism is that the formation 3-phosphorylated phosphoinositide $\left(\mathrm{PIP}_{3}\right)$ in the plasma membrane by $\mathrm{PI} 3-\mathrm{K}$ stimulates the activation of phospholipase $\mathrm{C} \gamma$ isoforms and, hence, increases $\mathrm{Ca}^{2+}$ mobilization, as in other cell types. ${ }^{41}$ Indeed, it has been demonstrated that platelet phospholipase $C \gamma 2$ is phosphorylated following $\alpha$ llb $\beta 3$ activation. ${ }^{40}$ Part of the PI3K-dependent events may involve $\alpha$ llb $\beta 3$-mediated ADP secretion and autocrine $\mathrm{P}_{2} \mathrm{Y}_{12}$ receptor signaling, as apparent from the inhibitory effect of cangrelor. Recently, we reported that PI3K-dependent phospholipase C activation contributes to $\mathrm{P}_{2} \mathrm{Y}_{12}$-mediated procoagulant activity. ${ }^{42}$ Additional study will be necessary to fully elucidate this interplay between integrin and $P 2 Y_{12}$ effects.

A striking observation was that not all platelets that extensively spread on the fibrinogen surface showed PS exposure upon stimulation with thrombin. This has been reported earlier, ${ }^{43}$ and is in line with the observation that only part of the platelets in a thrombus show this response. ${ }^{22}$ In the latter study the PS-exposing platelets were shown to have inactivated $\alpha \operatorname{llb} \beta 3$ integrins. Given the current findings, this points to an interesting negative feedback loop: fibrinogen binding to activated $\alpha$ llb $\beta 3$ leads to 
increased PS exposure, but once (procoagulant) platelets have reached this activation state, the integrins will be switched off and the outside-in signaling stops. 


\section{References}

1. Ma YQ, Qin J, Plow EF. Platelet integrin $\alpha$ llbß3: activation mechanisms. J Thromb Haemost. 2007;5:1345-1352.

2. Nieswandt B, Moser M, Pleines I, Varga-Szabo D, Monkley S, Critchley D, Fassler R. Loss of talin1 in platelets abrogates integrin activation, platelet aggregation, and thrombus formation in vitro and in vivo. J Exp Med. 2007;204:3113-3118.

3. Phillips DR, Nannizzi-Alaimo L, Prasad KS. $\beta 3$ tyrosine phosphorylation in $\alpha$ llb $\beta 3$ (platelet membrane GP Ilb/llla) outside-in integrin signaling. Thromb Haemost. 2001;86:246-258.

4. Shattil SJ, Newman PJ. Integrins: dynamic scaffolds for adhesion and signaling in platelets. Blood. 2004;104:1606-1615.

5. Buensuceso CS, Arias-Salgado EG, Shattil SJ. Protein-protein interactions in platelet $\alpha$ llb $\beta 3$ signaling. Semin Thromb Hemost. 2004;30:427-439.

6. Watson SP, Auger JM, McCarty OJ, Pearce AC. GPVI and integrin $\alpha$ llb $\beta 3$ signaling in platelets. J Thromb Haemost. 2005;3:1752-1762.

7. Nesbitt WS, Kulkarni S, Giuliano S, Goncalves I, Dopheide SM, Yap CL, Harper IS, Salem $\mathrm{HH}$, Jackson SP. Distinct glycoprotein Ib/V/IX and integrin allb $\beta 3$-dependent calcium signals cooperatively regulate platelet adhesion under flow. J Biol Chem. 2002;277:2965-2972.

8. Shattil SJ, Kashiwagi $\mathrm{H}$, Pampori N. Integrin signaling: the platelet paradigm. Blood. 1998;91:2645-2657.

9. Cauwenberghs S, Feijge MA, Harper AG, Sage SO, Curvers J, Heemskerk JW. Shedding of procoagulant microparticles from unstimulated platelets by integrin-mediated destabilization of actin cytoskeleton. FEBS Lett. 2006;580:5313-5320.

10. Heemskerk JW, Kuijpers MJ, Munnix IC, Siljander PR. Platelet collagen receptors and coagulation. A characteristic platelet response as possible target for antithrombotic treatment. Trends Cardiovasc Med. 2005;15:86-92.

11. Monroe DM, Hoffman M, Roberts HR. Platelets and thrombin generation. Arterioscler Thromb Vasc Biol. 2002;22:1381-1389.

12. Reverter JC, Béguin S, Kessels H, Kumar R, Hemker HC, Coller BS. Inhibition of plateletmediated, tissue-factor-induced thrombin generation by the mouse/human chimeric 7E3 antibody. Potential implications for the effect of c7E3 Fab treatment on acute thrombosis and 'clinical restenosis'. J Clin Invest. 1996;98:863-874.

13. Vanschoonbeek K, Feijge MA, van Kampen RJ, Kenis H, Hemker HC, Giesen PLA, Heemskerk JW. Initiating and potentiating role of platelets in tissue factor-induced thrombin generation in the presence of plasma: subject-dependent variation in thrombogram characteristics. J Thromb Haemost. 2004;2:476-484.

14. Ilveskero $\mathrm{S}$, Lassila R. Abciximab inhibits procoagulant activity but not the release reaction upon collagen- or clot-adherent platelets. J Thromb Haemost. 2003;1:805-813.

15. Keularts IM, Béguin S, de Zwaan C, Hemker HC. Treatment with a GPIIb/Illa antagonist inhibits thrombin generation in platelet rich plasma from patients. Thromb Haemost. 1998;80:370-371.

16. Gemmell $\mathrm{CH}$, Sefton MV, Yeo EL. Platelet-derived microparticle formation involves glycoprotein Ilb/llla. Inhibition by RGDS and a Glanzmann's thrombasthenia defect. J Biol Chem. 1993;268:14586-14589.

17. Goto S, Tamura N, Li M, Handa M, Ikeda Y, Handa S, Ruggeri ZM. Different effects of various anti-GPIlb/llla agents on shear-induced platelet activation and expression of procoagulant activity. J Thromb Haemost. 2003;1:2022-2030.

18. Byzova TV, Plow EF. Networking in the hemostatic system. Integrin $\alpha$ llb $\beta 3$ binds prothrombin and influences its activation. J Biol Chem. 1997;272:27183-27188.

19. Furman MI, Krueger LA, Frelinger AL, Barnard MR, Mascelli MA, Nakada MT, Michelson AD. GPIIb/llla antagonist-induced reduction in platelet surface factor $\mathrm{V} / \mathrm{Va}$ binding and phosphatidylserine expression in whole blood. Thromb Haemost. 2000;84:492-498. 
20. Pedicord DL, Thomas BE, Mousa SA, Dicker IB. Glycoprotein Ilb/llla receptor antagonists inhibit the development of platelet procoagulant activity. Thromb Res. 1998;90:247-258.

21. Lages B, Weiss HJ. Greater inhibition of platelet procoagulant activity by antibody-derived glycoprotein Ilb/llla inhibitors than by peptide and peptidomimetic inhibitors. $\mathrm{Br} \mathrm{J}$ Haematol. 2001;113:65-71.

22. Munnix IC, Kuijpers MJ, Auger J, Thomassen CM, Panizzi P, van Zandvoort MA, Rosing J, Bock PE, Watson SP, Heemskerk JW. Segregation of platelet aggregatory and procoagulant microdomains in thrombus formation: regulation by transient integrin activation. Arterioscler Thromb Vasc Biol. 2007;27:2484-2490.

23. Heemskerk JW, Bevers EM, Lindhout T. Platelet activation and blood coagulation. Thromb Haemost. 2002;88:186-193.

24. Rosing J, Tans G, Govers-Riemslag JW, Zwaal RF, Hemker HC. The role of phospholipids and factor Va in the prothrombinase complex. J Biol Chem. 1980;255:274-283.

25. Siljander P, Farndale RW, Feijge MA, Comfurius P, Kos S, Bevers EM, Heemskerk JW. Platelet adhesion enhances the glycoprotein VI-dependent procoagulant response: Involvement of p38 MAP kinase and calpain. Arterioscler Thromb Vasc Biol. 2001;21:618627.

26. Rosado JA, Meijer EM, Hamulyak K, Novakova I, Heemskerk JW, Sage SO. Fibrinogen binding to the integrin $\alpha$ llb $\beta 3$ modulates store-mediated calcium entry in human platelets. Blood. 2001;97:2648-2656.

27. van der Meijden PE, Feijge MA, Giesen PL, Huijberts M, van Raak LP, Heemskerk JW. Platelet $P 2 Y_{12}$ receptors enhance signaling towards procoagulant activity and thrombin generation. A study with healthy subjects and patients at thrombotic risk. Thromb Haemost. 2005;93:1128-1136.

28. Feijge MA, van Pampus EC, Lacabaratz-Porret C, Hamulyak K, Lévy-Toledano S, Enouf J, Heemskerk JW. Inter-individual variability in $\mathrm{Ca}^{2+}$ signaling in platelets from healthy volunteers: effects of aspirin and relationship with expression of endomembrane $\mathrm{Ca}^{2+}$ ATPases. Br J Haematol. 1998;102:850-859.

29. Heemskerk JW, Feijge MA, Henneman L, Rosing J, Hemker HC. The $\mathrm{Ca}^{2+}$-mobilizing potency of $\alpha$-thrombin and thrombin-receptor-activating peptide on human platelets. Concentration and time effects of thrombin-induced $\mathrm{Ca}^{2+}$ signaling. Eur J Biochem. 1997;249:547-555.

30. Siljander PR, Munnix IC, Smethurst PA, Deckmyn H, Lindhout T, Ouwehand WH, Farndale RW, Heemskerk JW. Platelet receptor interplay regulates collagen-induced thrombus formation in flowing human blood. Blood. 2004;103:1333-1341.

31. Marciniak SJ, Jr., Jordan RE, Mascelli MA. Effect of $\mathrm{Ca}^{2+}$ chelation on the platelet inhibitory ability of the GPIlb/llla antagonists abciximab, eptifibatide and tirofiban. Thromb Haemost. 2001;85:539-543.

32. Schrör K, Weber AA. Comparative pharmacology of GP IIb/llla antagonists. J Thromb Thrombolysis. 2003;15:71-80.

33. Razmara M, Hu H, Masquelier M, Li N. Glycoprotein Ilb/llla blockade inhibits platelet aminophospholipid exposure by potentiating translocase and attenuating scramblase activity. Cell Mol Life Sci. 2007;64:999-1008.

34. Léon C, Ravanat C, Freund M, Cazenave JP, Gachet C. Differential involvement of the P2Y, and $\mathrm{P}_{2} \mathrm{Y}_{12}$ receptors in platelet procoagulant activity. Arterioscler Thromb Vasc Biol. 2003;23:1941-1947.

35. Storey RF, Sanderson HM, White AE, May JA, Cameron KE, Heptinstall S. The central role of the P2T receptor in amplification of human platelet activation, secretion and procoagulant activity. Br J Haematol. 2000;110:925-934.

36. Bachelot-Loza C, Badol P, Brohard-Bohn B, Fraiz N, Cano E, Rendu F. Differential regulation of platelet aggregation and aminophospholipid exposure by calpain. $\mathrm{Br} J$ Haematol. 2006;133:419-426.

37. Kulkarni S, Jackson SP. Platelet factor XIII and calpain negatively regulate integrin $\alpha$ llb $\beta 3$ adhesive function and thrombus growth. J Biol Chem. 2004;279:30697-30706. 
38. Weiss HJ, Lages B. Platelet prothrombinase activity and intracellular calcium responses in patients with storage pool deficiency, glycoprotein Ilb/llla deficiency, or impaired platelet coagulant activity - a comparison with Scott syndrome. Blood. 1997;89:1599-1611.

39. Heemskerk JW, Vuist WM, Feijge MA, Reutelingsperger CP, Lindhout T. Collagen but not fibrinogen surfaces induce bleb formation, exposure of phosphatidylserine, and procoagulant activity of adherent platelets: evidence for regulation by protein tyrosine kinase-dependent $\mathrm{Ca}^{2+}$ responses. Blood. 1997; 90:2615-2625.

40. Goncalves I, Hughan SC, Schoenwaelder SM, Yap CL, Yuan Y, Jackson SP. Integrin $\alpha$ llbß33dependent calcium signals regulate platelet-fibrinogen interactions under flow. Involvement of phospholipase C $\gamma 2$. J Biol Chem. 2003;278:34812-34822.

41. Scharenberg AM, Kinet JP. Ptdlns-3,4,5-P3: a regulatory nexus between tyrosine kinases and sustained calcium signals. Cell. 1998;94:5-8.

42. van der Meijden PE, Schoenwaelder SM, Feijge MA, Cosemans JM, Munnix IC, Wetzker R, Heller R, Jackson SP, Heemskerk JW. Dual P2Y 12 receptor signaling in thrombin-stimulated platelets. Involvement of phosphoinositide 3-kinase $\beta$ but not $\gamma$ isoform in $\mathrm{Ca}^{2+}$ mobilization and procoagulant activity. FEBS J. 2008;275:371-385.

43. Briedé JJ, Heemskerk JW, Hemker HC, Lindhout T. Heterogeneity in microparticle formation and exposure of anionic phospholipids at the plasma membrane of single adherent platelets. Biochim Biophys Acta. 1999;1451:163-172. 


\section{Dual role of collagen in factor XII-dependent thrombus and clot formation}

Paola E.J. van der Meijden, Imke C.A. Munnix, Jocelyn M. Auger,

José W. Govers-Riemslag, Judith M.E.M. Cosemans, Marijke J.E. Kuijpers,

Henri M. Spronk, Steve P. Watson, Thomas Renné and Johan W.M. Heemskerk

Blood; invited resubmission 


\section{Abstract}

In vivo thrombosis models have shown that the intrinsic coagulation pathway, initiated by factor XII, plays an important role in the thrombotic process. In the present study we show that in plasma, fibrillar type I collagens caused a dose-dependent shortening of the clotting time initiated by factor XIla. In vitro, type I collagen bound factor XII and increased its proteolytic activity. In the presence of platelets, collagen potently enhanced thrombin generation via the combined activation of factor XII and glycoprotein VI. Under flow conditions, collagen surfaces promoted the formation of thrombi rich in fibrin(ogen) and phosphatidylserine-exposing platelets. Thrombus formation and procoagulant activity were markedly reduced, when factor XIla was blocked or when factor XII or XI were absent. Furthermore, formation of procoagulant thrombi was also dependent on glycoprotein VI signaling, as this response was greatly diminished with platelets deficient in LAT or phospholipase $\mathrm{C} \gamma 2$. In contrast, blockade of the tissue factor/factor VIla pathway had no or minimal effect. Together, these results point to a dual role of collagen in thrombus formation: initiation of coagulation via factor XII activation, and stimulation of glycoprotein $\mathrm{VI}$ signaling via LAT and $\mathrm{PLC} \gamma 2$, to provide a procoagulant membrane surface for massive fibrin formation and clotting.

\section{Introduction}

Vascular injury leads to exposure of hemostatic subendothelial components, such as tissue factor and collagen to the blood stream. Until recently, exposure of tissue factor was considered to be the principal way of activation of the coagulation cascade. In the extrinsic coagulation pathway, tissue factor complexes with circulating factor (F)VII(a), which leads via a multistep cascade of activated serine proteases to formation of thrombin and fibrin. ${ }^{1}$ Exposed collagen was considered solely to function as a substrate for platelet adhesion and activation via the glycoprotein VI (GPVI) receptor, causing powerful signaling events. ${ }^{2}$

The intrinsic (blood-borne) coagulation pathway is initiated by activation of FXII (Hageman factor), which results in sequential activation of FXI and FIX. For long, the physiological importance of this pathway has remained obscure, in part because the initial trigger in vivo was not known. However, in vitro, FXII undergoes powerful activation upon exposure to negatively charged materials like kaolin, glass or ellagic acid. This type of activation forms the basis of a widely used coagulation test, the activated partial thromboplastin time (aPTT). Early evidence suggests that vascular polyanionic components like cerebroside sulfates and glycosaminoglycans can promote FXII activation. $^{3,4}$ In addition, vascular collagens have also been proposed to play a role in FXII activation and coagulation. ${ }^{5,6}$ Other papers at that time, however, stipulated absence of effect or even inhibition of FXII activation by collagens. ${ }^{7,8}$

Recent developments of in vivo mouse thrombosis models have led to increasing recognition of the importance of FXII in thrombus formation and coagulation. In a number of models where the thrombotic process was induced by collagen exposure due to vascular damage, the absence or inhibition of FXII had a marked antithrombotic effect. ${ }^{9}$ 
Furthermore, in a middle cerebral artery model of ischemia-reperfusion injury, FXII deficiency diminished thrombus formation and reduced infarction volume in the brain vessels. ${ }^{10}$ Interestingly in the same models, also FXI deficiency led to thrombosis protection. ${ }^{10,11}$ We have suggested that platelet activation is implicated in the FXIIdependent thrombus formation, but the mechanism remained unclear. ${ }^{9}$

The immunoglobulin collagen receptor, GPVI, in association with the FcR $\gamma$-chain coreceptor, activates platelets via a tyrosine phosphorylation chain involving sequential activation of Src and Syk kinases. This initiates a downstream signaling cascade via the adapter protein LAT and the key effector enzyme, phospholipase C $\gamma 2$ (PLC $\gamma 2){ }^{2,12}$ We and others have shown that collagen-induced signaling from GPVI to PLC $\gamma 2$ plays a controlling role in flow-mediated platelet thrombus formation both in vivo and in vitro. ${ }^{13-15}$ Furthermore, this pathway stimulates platelet procoagulant activity, converting platelets into cells exposing phosphatidylserine (PS), at which coagulation factors bind and become activated. $^{14,16}$

Here, we hypothesized that collagen has a more extended role in thrombus and clot formation next to stimulating platelet GPVI, i.e. by triggering the intrinsic pathway of coagulation via activation of FXII. This hypothesis is tested in the present study using both human and mouse blood.

\section{Methods}

\section{Materials}

Fibrillar type I Horm (type I/H) collagen was from Nycomed (Munich, Germany); fibrillar type I equine (type I/E) collagen from Merck, fibrillar type I bovine (type I/B) collagen from Sigma and bovine type I collagen purified (type I/P), as described. ${ }^{17}$ Collagen preparations were checked on protein contamination by gel-electrophoresis and dialyzed against collagen buffer. Prekallikrein and high molecular weight kininogen came from Enzyme Research Laboratories (South Bend, IN). Corn trypsin inhibitor (CTI) and recombinant human FXII from Haematologic Technologies (Essex, VT); recombinant human tissue factor from Dade Behring (Marburg, Germany); and human FXII-deficient plasma from George King Bio-Medical (Overland Park, KS). Active-site inactivated FVIla (FVIlai) was kindly provided by Novo Nordisk (Malov, Denmark); Oregon Green (OG)488-labeled annexin A5, Alexa Fluor (AF)546-labeled fibrinogen, and AF633labeled streptavidin were from Molecular Probes (Leiden, The Netherlands); thrombin substrate, Z-Gly-Gly-Arg aminomethyl coumarin (Z-GGR-AMC) from Bachem (Bubendorf, Switzerland); the FXIla substrate, Pefachrome FXIla (5963), from Pentapharm (Basel, Switzerland). Preparation of procoagulant phospholipid vesicles (PS : phosphatidylcholine : phosphatidylethanolamine $1: 3: 1 ; \mathrm{mol} / \mathrm{mol} / \mathrm{mol})$ is described elsewhere. $^{18}$ The preparation of biotin-labeled anti-FXII mAb (F3 against human/mouse FXII) is as described. ${ }^{19}$ Anti-PLC $\gamma 2$ mAb DN84 was from DNAX Research Institute (Palo Alto, CA), anti-phosphotyrosine 4G10 mAb from Upstate Biotechnology (Bucks, United Kingdom), and FITC-anti-GPIb $\beta$ Xia.C3 mAb from Emfret (Würzburg, Germany). Anti- 
GPVI JAQ1 mAb was a kind gift of Dr. Nieswandt (Virchow Research Centre, Würzburg, Germany). Human thrombin calibrator came from Thrombinoscope (Maastricht, The Netherlands). FITC-labeled avidin was from Vector Laboratories (Burlingame, CA). Other materials including collagenase from C. histolyticum were from Sigma (St. Louis, MO).

\section{Animals}

Animal experiments were approved by the local animal experimental committees. Control C57BI/6 mice were obtained from Charles River (Maastricht, The Netherlands). Mice homozygously deficient in LAT or PLC $\gamma 2$ were bred from heterozygotes with a C57BI/6 background. ${ }^{20,21}$ Mice homozygous for null mutations in the FXI or FXII gene were generated, as described. ${ }^{22,23}$ The animals were crossbred for $>10$ generations at a C57BI/6J background. Per experimental set, wildtypes, heterozygotes and homozygotes from the same breeding were used; all animals were genotyped. Blood cell counts of all animal types were in the normal range.

\section{Blood collection}

Human blood was taken from healthy volunteers, who gave full informed consent; subjects were free from medication for at least two weeks. Blood was collected by freely dripping into $1 / 10$ vol. $129 \mathrm{mM}$ trisodium citrate (first $2 \mathrm{~mL}$ removed). Mouse blood, drawn from animals under anesthesia, was collected into the same citrate solution. ${ }^{14}$ Platelet-rich plasma (PRP) and platelet-free plasma (PFP) were freshly prepared, as described for human and mouse systems. ${ }^{24,25}$ Note that PFP was centrifuged twice at $1500 \mathrm{~g}$ for 4 minutes to remove all platelets. Platelet count was checked with a thrombocounter (Coulter Electronics, Luton, United Kingdom).

\section{Clotting times and factor levels}

Clotting times were measured with a $\mathrm{KC}-4 \mathrm{~A}$ coagulometer at $37^{\circ} \mathrm{C}$. Normalized human PRP $\left(2 \times 10^{8}\right.$ platelets $\left./ \mathrm{mL}\right)$ was used or PFP supplemented with $10 \mu \mathrm{M}$ procoagulant phospholipid vesicles. Tubes were pre-rinsed with saline containing 1\% BSA. Plasma samples were preincubated with collagen or tissue factor for 5 minutes, after which coagulation was triggered by addition of $\mathrm{CaCl}_{2}(16.6 \mathrm{mM}$, f.c.).

Coagulation times (aPTT, PT) in mouse plasma were determined as described previously. ${ }^{9}$ Levels of coagulation factors in plasma from wildtype, $\mathrm{FXI}^{-/-}$and $\mathrm{FXI}^{-/-}$mice were determined with an automated blood coagulation system (BCS; Dade Behring), using reagents and protocols for human plasma. No significant difference in factor levels was found between wildtype and factor-deficient mice, except for the factor that was knocked out. Platelet-free plasma from mice deficient in LAT or PLC $\gamma 2$ had normal coagulation profiles. 


\section{Thrombin generation}

Thrombin generation was measured in citrate-anticoagulated human or mouse PRP $\left(1 \times 10^{8}\right.$ platelets $/ \mathrm{mL}$, f.c.) or in PFP supplemented with phospholipid vesicles $(4 \mu \mathrm{M})$, basically as before. ${ }^{26}$ Briefly, plasmas were preincubated with inhibitors and treated with collagen or right vehicle for 10 minutes. Samples (4 vol.) were pipetted into a polystyrene 96-wells plate (Immulon 2HB, Dynex Technologies, Chantilly, VA), already containing 1 vol. of buffer A (20 mM Hepes, $140 \mathrm{mM} \mathrm{NaCl}$ and $0.5 \% \mathrm{BSA}$ ). Assays were run in Immulon $2 \mathrm{HB}$ polystyrene well-plates, as these showed minimal levels of contact activation. Tissue factor was only added if indicated. Coagulation was started by adding 1 vol. of buffer B (2.5 mM Z-GGR-AMC, $20 \mathrm{mM}$ Hepes, $140 \mathrm{mM} \mathrm{NaCl}, 100 \mathrm{mM} \mathrm{CaCl} 2$ and $6 \% \mathrm{BSA}$ ). First-derivative curves of accumulation of fluorescence in human plasma were converted into $\mathrm{nM}$ thrombin using a human calibrator. Thrombin levels in mouse plasma are shown as arbitrary activity units (AAU), since substrate cleavage rate by murine thrombin is unknown. Samples were run at least in duplicate. Controls were carried out with FVIlai, which is effective in both human and mouse plasma, to check for residual contribution of the extrinsic coagulation pathway.

\section{Binding and activation of factor XII}

Coverslips were spotted with a fibrillar type I collagen $(1 \mu \mathrm{g})$, washed and blocked with $1 \%$ BSA. Coverslips were incubated for 10 minutes with FXII in the presence or absence of prekallikrein/high molecular weight kininogen. After three wash steps with PBS, coverslips were stained with biotinylated anti-FXII mAb (1:50) or biotinylated control IgG, followed by AF633-streptavidin (1:200) or FITC-labeled avidin (1:200). Negative controls were run by omission of anti-FXIla $\mathrm{mAb}$ and positive controls by (strept)avidin preblocking. Fluorescence images were recorded by two-photon laser scanning microscopy at fixed settings of laser power, gain and pinhole. ${ }^{27}$

Enzymatic activity of FXIla was measured with Pefachrome FXIla in Hepes buffer $\mathrm{pH}$ 7.45. Purified FXII $(7.5 \mu \mathrm{g} / \mathrm{mL})$, prekallikrein $(2.5 \mu \mathrm{g} / \mathrm{mL})$ and high molecular weight kininogen $(3.5 \mu \mathrm{g} / \mathrm{mL})$ were incubated in the presence or absence of collagens or platelets for 15 minutes. After addition of $0.8 \mathrm{mM}$ Pefachrome FXIla, the increase in absorption at $405 \mathrm{~nm}$ was determined at $37^{\circ} \mathrm{C}$.

\section{Thrombus and clot formation under flow}

For thrombus formation, coverslips were coated with a fibrillar type I collagen $\left(10 \mathrm{~mm}^{2}\right.$ by $25 \mu \mathrm{L}$ application of a $50 \mu \mathrm{g} / \mathrm{mL}$ solution) and blocked with Hepes buffer $\mathrm{pH} 7.45$ (5 mM Hepes, $136 \mathrm{mM} \mathrm{NaCl}, 2.7 \mathrm{mM} \mathrm{KCl}, 0.42 \mathrm{mM} \mathrm{NaH} \mathrm{PO}_{4}, 2 \mathrm{mM} \mathrm{MgCl}_{2}$ and $1 \% \mathrm{BSA}$ ). Uncoated coverslips were blocked with the same BSA-containing buffer. The coverslips were placed onto a transparent, $50 \mu \mathrm{m}$-deep parallel-plate flow chamber, and the chamber was pre-rinsed with BSA-containing buffer. Chambers were then co-infused with citrate-anticoagulated blood (1 vol.) and isotonic $\mathrm{CaCl}_{2} / \mathrm{MgCl}_{2}$ solution $(110 \mathrm{mM}$ $\mathrm{NaCl}, 13.3 \mathrm{mM} \mathrm{CaCl}_{2}$ and $6.7 \mathrm{mM} \mathrm{MgCl}_{2} ; 1$ vol.). This resulted in physiological free $\mathrm{Ca}^{2+}$ and $\mathrm{Mg}^{2+}$ concentrations of $\sim 2 \mathrm{mM}$ each. Blood samples were pre-incubated for 15 
minutes with indicated inhibitor. After 4-6 minutes of flow (shear rate 150-1000 s${ }^{-1}$ ), flow chambers were rinsed with Hepes buffer $\mathrm{pH} 7.45$ containing $2 \mathrm{mM} \mathrm{CaCl}, 1 \mathrm{U} / \mathrm{mL}$ heparin. Fluorescent probe was present in blood or in rinse buffer $(0.5 \mu \mathrm{g} / \mathrm{mL}$ OG488annexin A5 or $200 \mu \mathrm{g} / \mathrm{mL}$ AF546-fibrinogen). Bright-field phase contrast and nonconfocal fluorescent images were recorded, using equipment described before. ${ }^{14}$ Confocal fluorescence images were recorded using a Nikon Eclipse E600 microscope equipped with $\mathrm{C} 1$ confocal scanning head. Scanning was at 50 lines per second and 2x Kalman averaging. Images were processed with ImagePro software.

\section{Immunoprecipitation and western blotting}

Washed platelets $\left(5 \times 10^{8}\right.$ platelets $\left./ \mathrm{mL}\right)$ were stimulated with $10 \mu \mathrm{g} / \mathrm{mL}$ type I collagens for $90 \mathrm{~s}$ in the presence of EGTA to prevent aggregation. Activated platelets were lysed, and PLC $\gamma 2$ was immunoprecipitated using anti-PLC $\gamma 2$ mAb, as described. ${ }^{28}$ Immunoprecipitated proteins were separated by gel electrophoresis, subjected to western blotting, probed for phospho-tyrosine and re-probed for PLC $\gamma 2{ }^{29}$

\section{Statistics}

Significance of differences was determined with the Mann-Whitney $U$ test or the independent samples $t$ test, as appropriate, using the statistical package for social sciences (SPSS 11.0, Chicago, IL). Size distribution of platelet thrombi was evaluated by $\chi^{2}$ analysis.

\section{Results}

\section{Collagen stimulates clotting and thrombin generation by activation of FXII}

It was investigated how collagen affects the coagulation process independently of tissue factor. First, clotting times were measured in citrate-anticoagulated human plasma following activation with $\mathrm{CaCl}_{2}$ but no tissue factor. Figure $1 \mathrm{~A}$ shows that type I collagen Horm (type $\mathrm{I} / \mathrm{H}$ ), in a dose-dependent way, significantly shortened the clotting time of plasma in comparison to vehicle (collagen buffer added at same volumes). At $40 \mu \mathrm{g} / \mathrm{mL}$ collagen, the clotting time was reduced from $>500$ to $\sim 200$ seconds, with either phospholipid vesicles or platelets present as procoagulant lipid surface. Similar results were obtained with a range of purified fibrillar type-I collagens from various sources, i.e. types I/E, I/B and I/P (data not shown, but see below). Treatment of these preparations with collagenase from $C$. histolyticum abolished the collagen effect on clotting time, thus demonstrating that it was not caused by impurities in the collagens. Markedly, collagen was unable to shorten the clotting time in FXII-deficient human plasma, while its effect was completely blocked by the FXII inhibitor, CTI $\left(\mathrm{IC}_{50} 15 \mu \mathrm{g} / \mathrm{mL}\right)$, again in the presence of phospholipid vesicles or platelets (Figure 1A). On the other hand, with tissue factor present which by itself shortened clotting times, CTI had no additional effect in neither normal nor FXII-deficient plasma. 
Ai

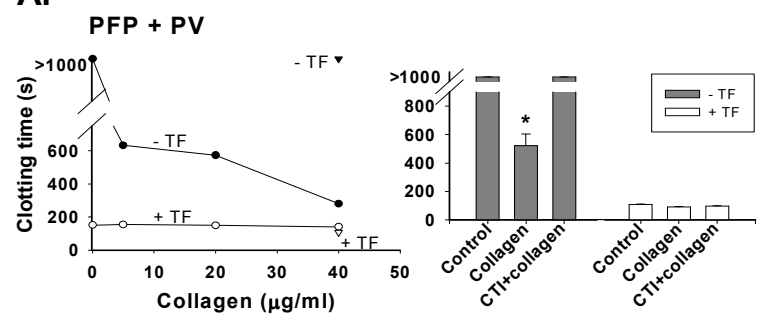

Aii

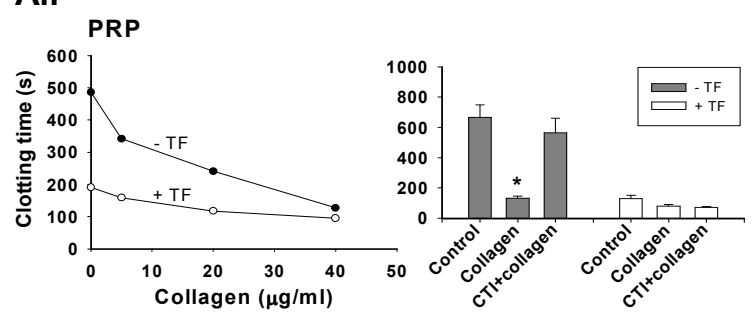

Bi
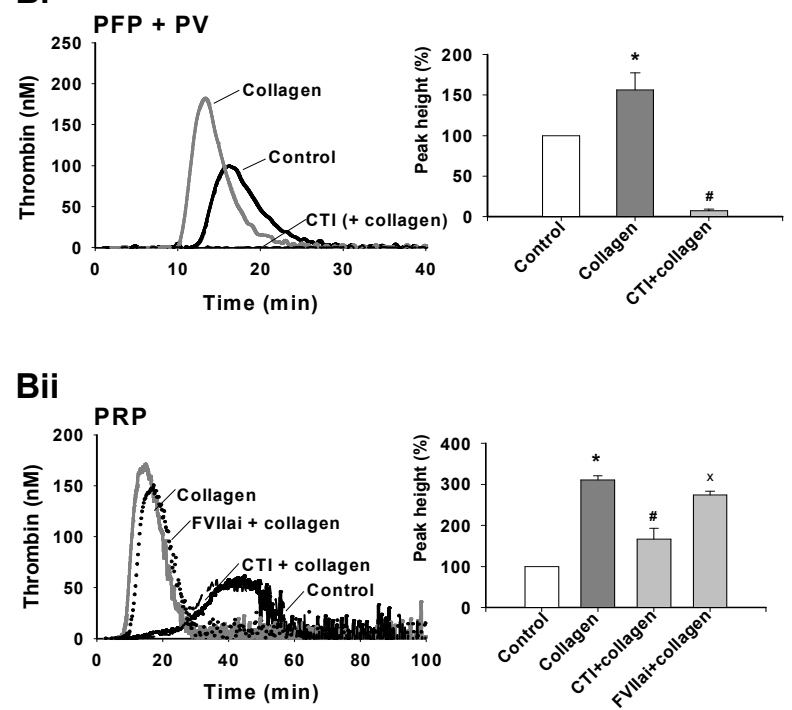

Figure 1. Collagen enhances coagulation in the absence of platelets and tissue factor. Human plasma containing phospholipid vesicles (PFP + PV) or platelets (PRP) was pretreated with CTI (50 $\mu \mathrm{g} / \mathrm{mL}$ ) or FVllai $(5 \mu \mathrm{g} / \mathrm{mL}$ ), as indicated. Pre-incubation was with collagen buffer (vehicle control) or collagen type I Horm (type I/H); activation was with $\mathrm{CaCl}_{2}(16.6 \mathrm{mM})$. Tissue factor (1 pM) was only added, where indicated. (A) Dose-dependent shortening by collagen (standard $40 \mu \mathrm{g} / \mathrm{mL}$ ) of coagulation time in control plasma (circles) and FXII-deficient plasma (triangles). Note marked effect in the absence of tissue factor (closed symbols) vs. presence of tissue factor (open symbols). (B) Increased thrombin generation by collagen $\mathrm{l} / \mathrm{H}(5 \mu \mathrm{g} / \mathrm{mL})$ in the presence of phospholipid vesicles or platelets (no tissue factor added). Bars give thrombin peak height, normalized to the control condition with collagen buffer. Other collagens had similar effects. Means \pm SEM $(n=3-5),{ }^{*} p<0.05 v s$. control, ${ }^{p} p<0.05$ vs. condition with collagen. 
Thrombin generation experiments were carried out to confirm the procoagulant effect of type I collagens. Polystyrene (Immulon 2HB) well plates were used in this case, as this material has a minimal contribution to contact activation. In the presence of phospholipids (without added tissue factor), collagen $\left(E_{50} 2 \mu \mathrm{g} / \mathrm{mL}\right.$ ) markedly shortened the lag-time and increased the peak height of thrombin generation, while CTI treatment abrogated all thrombin generation (Figure 1Bi). Collagen also potentiated thrombin generation in the presence of platelets (Figure 1Bii). This ability was only little influenced by the tissue factor inhibitor, FVIlai $(5 \mu \mathrm{g} / \mathrm{mL}$, i.e. sufficient to block $1 \mathrm{pM}$ tissue factor), and it was greatly but not completely antagonized by CTI. Again this collagen effect was abolished by pretreatment with collagenase from $C$. histolyticum. Together, these data demonstrate that collagen can markedly increase the thrombin generation process via activation of FXII, both in the presence and absence of platelets.

A
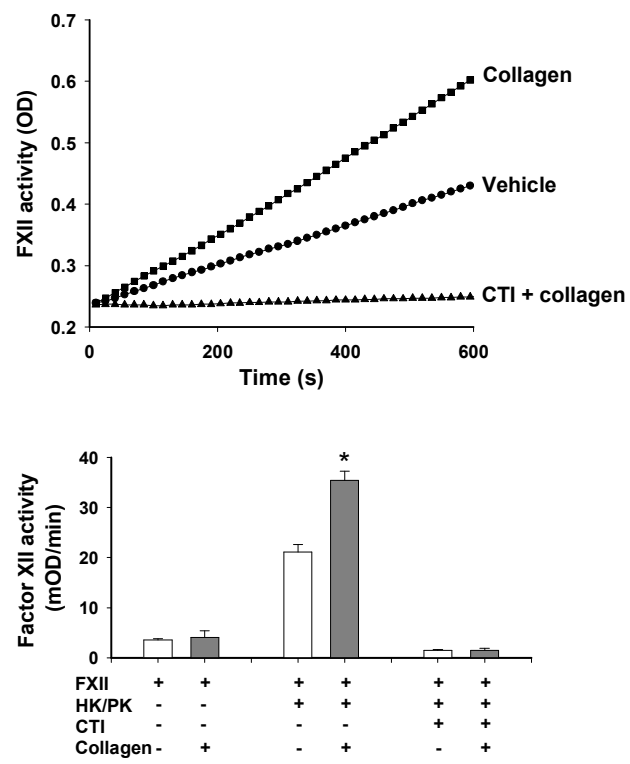

B

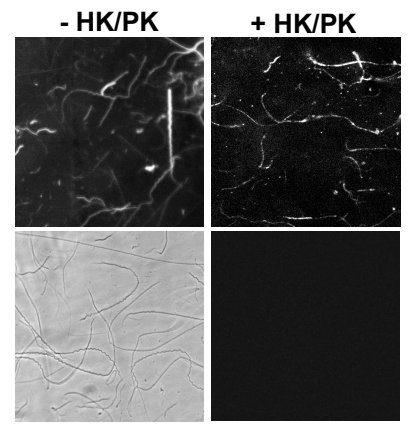

Phase contrast Negative control

C

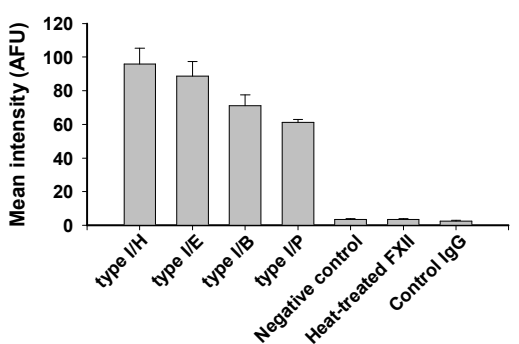

Figure 2. Collagen binds FXII and enhances FXII activation. (A) Effect of collagen on FXII activation. FXII $(7.5 \mu \mathrm{g} / \mathrm{mL})$ was incubated at $37^{\circ} \mathrm{C}$ with prekallikrein $(\mathrm{PK}, 2.5 \mu \mathrm{g} / \mathrm{mL})$, high molecular weight kininogen ( $\mathrm{HK}, 3.5 \mu \mathrm{g} / \mathrm{mL})$, type $\mathrm{I} / \mathrm{H}$ collagen $(5 \mu \mathrm{g} / \mathrm{mL})$ and $\mathrm{CTI}(50 \mu \mathrm{g} / \mathrm{mL})$, as indicated. Cleavage rate of Pefachrome FXIla substrate $(0.8 \mathrm{mM})$ was determined as $\Delta \mathrm{mOD} / \mathrm{min}$. (B-C) Binding of FXII to collagen. Coverslips containing various fibrillar type I collagens were incubated with FXII $\pm \mathrm{PK} / \mathrm{HK}$ (concentrations as above) for 10 minutes, and after extensive rinse stained with biotin-labeled anti-FXII mAb and FITC-avidin. Controls were coverslips coated with collagen type $\mathrm{I} / \mathrm{H}$ that were: (i) stained without anti-FXII mAb (negative control), (ii) incubated with heat-treated FXII (5 minutes at $56^{\circ} \mathrm{C}$ ), or (iii) stained with biotin control IgG. Confocal images $(180 \times 180 \mu \mathrm{m})$ were analyzed for staining intensity of collagen fibers. Data are from independent measurements (means \pm SEM, $n=3-4,{ }^{*} p<0.05$ vs. condition without collagen). 


\section{Collagen binds and activates factor XII}

The effect of collagen on FXII activation was studied in a test system with purified coagulation factors. This purified system was used, because we observed that the commercially available peptide-based FXII substrates and FXII active-site inhibitors are non-selective towards FXII in the presence of coagulating plasma. With high molecular weight kininogen and prekallikrein, preparations of human FXII slowly cleaved chromogenic substrate for FXIla, most likely due to kallikrein-mediated auto-activation. However, in the presence of fibrillar collagen this chromogenic activity was markedly increased (Figure 2A). The activity was completely inhibited by CTI, thus demonstrating specificity for FXIla.

As these results suggested that the binding of FXII to collagen enhances its activation by prekallikrein/kininogen, Biacore experiments were performed with collagencoated microchips. Human FXII showed dose-dependent reversible binding to the chips (not shown), confirming a direct interaction. However, data analysis was hampered by complex, high background binding of FXII to the chip material, which precluded establishment of binding parameters. In an alternative approach, FXII-collagen interaction was determined by immunofluorescence detection. Coverslips containing immobilized type I collagens were incubated with purified FXII and immuno-stained for this factor. Two-photon scanning fluorescence microscopy showed marked staining which was completely restricted to the collagen fibers and was not affected by the

A
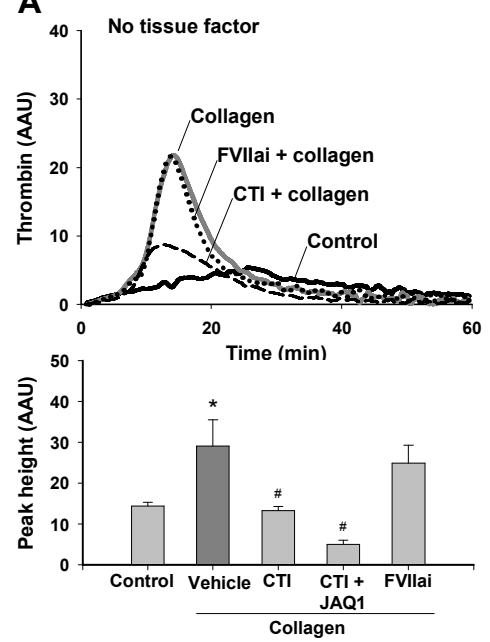

B
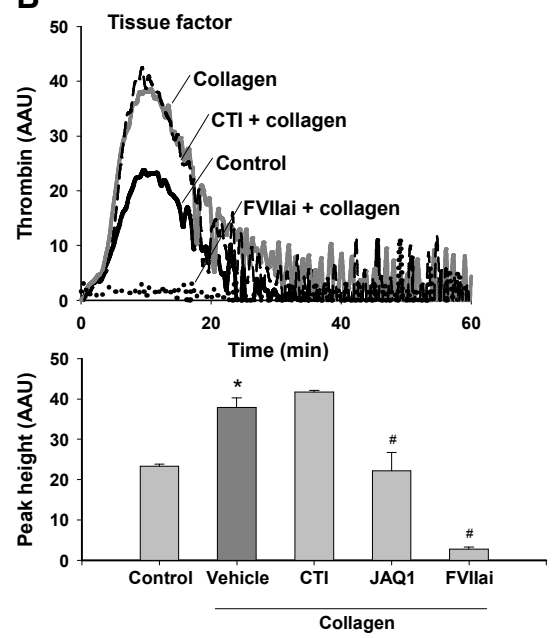

Figure 3. FXII and platelet GPVI contribute to collagen-dependent thrombin generation in mouse. Thrombin generation was measured in PRP from wildtype mice, treated with vehicle (control; collagen buffer) or collagen type $\mathrm{I} / \mathrm{H}(5 \mu \mathrm{g} / \mathrm{mL})$, and triggered with $\mathrm{CaCl}_{2}$. Plasmas were preincubated with FVIlai $(5 \mu \mathrm{g} / \mathrm{mL})$, CTI $(50 \mu \mathrm{g} / \mathrm{mL})$ and/or JAQ1 $\mathrm{mAb}(40 \mu \mathrm{g} / \mathrm{mL})$. Thrombin generation curves were determined $(A)$ in the absence or $(B)$ presence of tissue factor (1 pM). Thrombin levels are given as arbitrary activity units (AAU). Means \pm SEM $(n=4),{ }^{*} p<0.05$ vs. control, ${ }^{\#} p<0.05$ vs. condition with collagen. 
presence of prekallikrein/kininogen (Figure 2B). Importantly, fibrillar type-I collagens from all sources (type I/H, I/E, I/B and I/P) showed a similar degree of FXII binding (Figure $2 \mathrm{C})$. In comparison, there was no staining on non-fibrillar collagens or after collagenase treatment; nor when anti-FXII mAb was omitted or if FXII was heat-treated. These results strongly suggest that the fluorescence was due to binding of FXII to the collagen fibers. Together, these results indicate that FXII can be activated following binding to collagen, and that this activation contributes to thrombin and fibrin clot formation.

\section{Collagen-dependent thrombus formation under flow and coagulation involves FXII}

The availability of mice lacking FXII enabled us to study more directly how FXII contributes to thrombus formation. Also in PRP of wildtype mice, collagen type $\mathrm{I} / \mathrm{H}$ markedly increased thrombin generation triggered by $\mathrm{CaCl}_{2}$ (Figure $3 \mathrm{~A}$ ). Similarly, type $\mathrm{I} / \mathrm{B}$ and I/P collagens $(5 \mu \mathrm{g} / \mathrm{mL})$ increased the thrombin peak height to $\sim 225 \%$. As with human PRP, the effect of collagen was partly inihibited by CTI (IC $\left.\mathrm{C}_{50} 10 \mu \mathrm{g} / \mathrm{mL}\right)$ but not by FVIlai; the remainder was blocked by anti-GPVI mAb JAQ1 (Figure 3A). In the presence of tissue factor, collagen still enhanced thrombin generation, but this effect was now only sensitive to blockade of GPVI by JAQ1 but not to CTI (Figure 3B). This suggested that, without tissue factor, the collagen-induced effect on thrombin generation is mediated by coagulation activation via FXII as well as platelet activation via GPVI, whereas in the
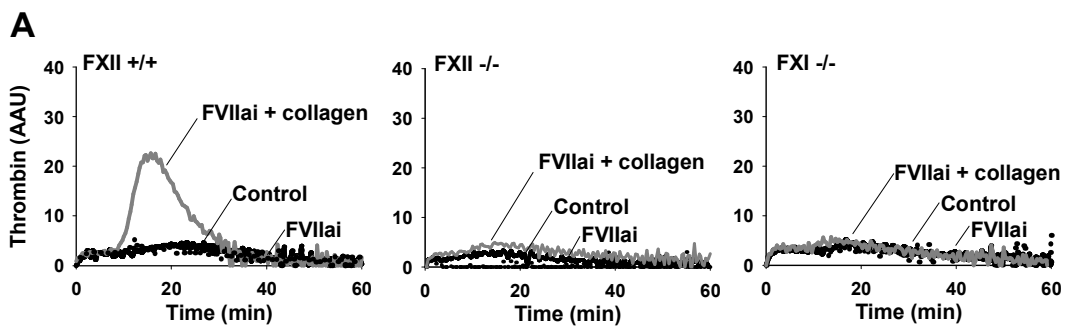

B
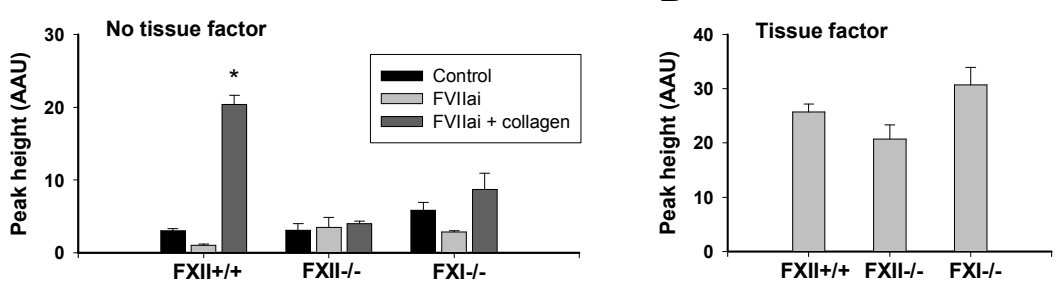

Figure 4. Deficiency in FXII or FXI abolishes collagen enhancement of thrombin generation. Plasmas (PFP) from $\mathrm{FXII}^{+/+}, \mathrm{FXII}^{-/}$and $\mathrm{FXI}^{-/-}$mice were supplemented with washed platelets, pooled from wildtype C57BI/6 mice $\left(1 \times 10^{8}\right.$ platelets $/ \mathrm{mL}$, f.c.). Samples were pre-treated with collagen buffer (vehicle control), collagen type $\mathrm{l} / \mathrm{H}(5 \mu \mathrm{g} / \mathrm{mL}$ ) and/or FVllai $(5 \mu \mathrm{g} / \mathrm{mL})$, as indicated. (A) Thrombin generation was triggered by addition of $\mathrm{CaCl}_{2}$. Shown are thrombograms and thrombin peak heights, expressed as arbitrary activity units (AAU). (B) Thrombin peak heights, after triggering with $1 \mathrm{pM}$ tissue factor (no FVIlai). Means \pm SEM $(n=4-5)$, ${ }^{*} p<0.05 \mathrm{vs}$. control. 
presence of tissue factor, only GPVI contributes to the response. These results are hence in line with those observed in human PRP.

Subsequently, the effect of FXII or FXI deficiency on thrombin generation was examined. Plasmas from wildtype, $\mathrm{FXII}^{-/-}$and $\mathrm{FXI}^{-/-}$mice were reconstituted with pooled wildtype platelets to avoid variation in platelet responsiveness. Thrombin generation curves showed that collagen provoked a marked increase in thrombin peak height in $\mathrm{FXII}^{+/+}$plasma, while this effect was completely abolished in plasmas from $\mathrm{FXII}^{-/-}$or $\mathrm{FXI}^{-1-}$ animals (Figure 4A). On the contrary, with tissue factor added, wildtype and factor deficient plasmas did not differ in thrombin generation profile (Figure 4B).

To study the importance of FXII-dependent thrombin generation at physiological flow conditions, blood from the mice was recalcified and perfused over collagen fibers at a moderate shear rate of $1000 \mathrm{~s}^{-1}$. Earlier studies with tissue factor present have shown
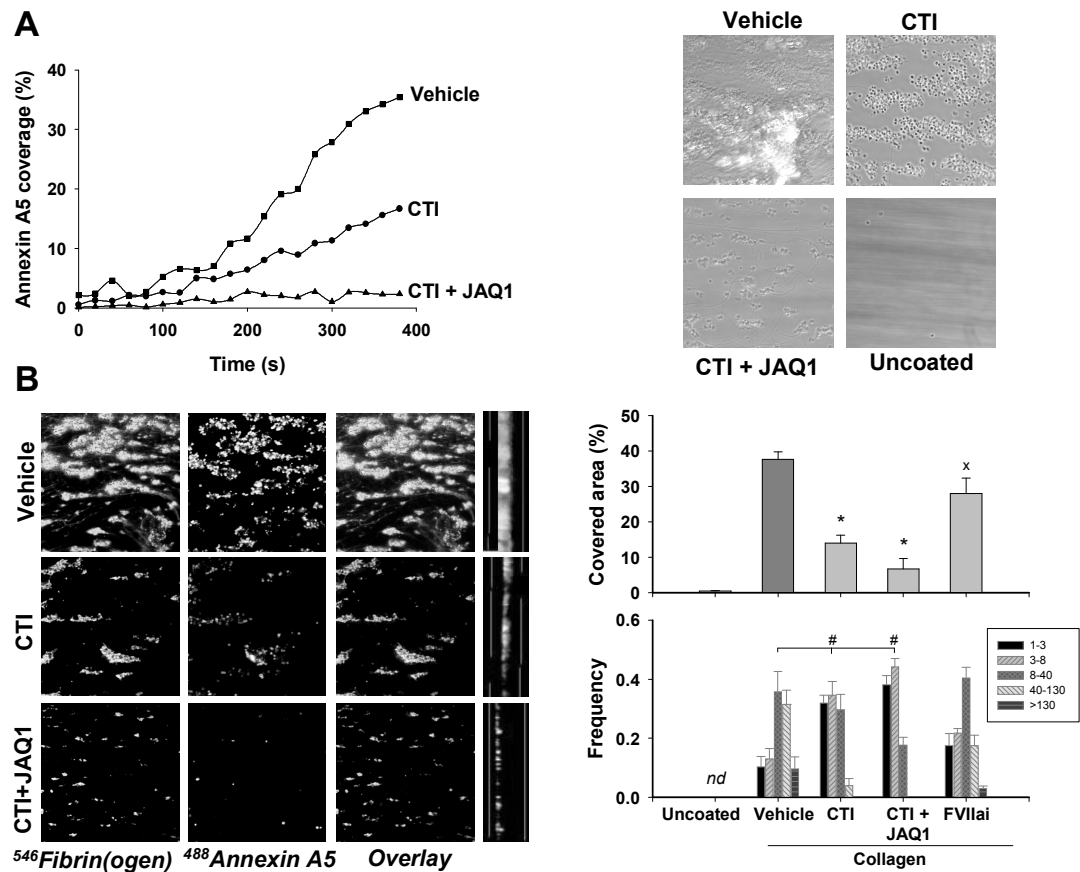

Figure 5. Blockage of FXII or platelet GPVI suppresses collagen-dependent thrombus and clot formation. Blood from wildtype mice was flowed over type $\mathrm{I} / \mathrm{H}$ collagen under coagulant conditions by 4-minutes co-perfusion with isotonic $\mathrm{CaCl}_{2} / \mathrm{MgCl}_{2}$ at $1000 \mathrm{~s}^{-1}$. Blood was pretreated with vehicle (control), CTI $(50 \mu \mathrm{g} / \mathrm{mL})$, JAQ1 $\mathrm{mAb}(40 \mu \mathrm{g} / \mathrm{mL})$ or FVIlai $(5 \mu \mathrm{g} / \mathrm{mL})$, as indicated. No tissue factor was added. (A) Staining of thrombi with OG488-annexin A5 added during perfusion $(0.5 \mu \mathrm{g} / \mathrm{mL})$. Representative experiment for 3 performed. (B) Projected confocal stacks $(180 \times 180$ $\mu \mathrm{m}, z=50 \mu \mathrm{m})$ co-stained with AF546-fibrinogen and OG488-annexin A5. Right panels are side views, indicating averaged thrombus height. (C) Phase contrast images $(120 \times 120 \mu \mathrm{m})$ after 4 minutes of flow. Control coverslips without collagen (uncoated) did not show platelet or fibrin deposition. Histograms show surface area coverage of thrombi, and frequency distribution of the feature sizes, i.e. single platelets, small and larger aggregates (numbers of platelets per feature are indicated). Means \pm SEM $(n=4-5),{ }^{*}{ }^{*} p<0.05 v s$. vehicle control (" for $\chi^{2}$ test). 
that such a flow protocol resulted in massive formation of fibrin-containing thrombi on collagen. ${ }^{27}$ For the present purpose, the flow system was extensively pre-rinsed with $1 \%$ BSA to prevent unspecific contact activation, and no tissue factor was added. At first, OG488-annexin A5 was added to wildtype mouse blood $(0.5 \mu \mathrm{g} / \mathrm{mL})$, to monitor procoagulant, PS-expressing platelets. Perfusion of recalcified blood resulted in rapid platelet adhesion and aggregation. Initially only platelets on collagen bound OG488annexin A5, but after several minutes, once fibrin fibers were formed, also aggregates started to bind annexin $A 5$, thus resulting in a strong increase in overall fluorescence (Figure 5A). Fluorescence accumulation was markedly suppressed in the presence of $\mathrm{CTI}$, and was virtually absent with the anti-GPVI mAb JAQ1 present as well.

Two-color confocal images of wildtype thrombi, formed in the presence of AF546fibrinogen and OG488-annexin A5, showed massive staining of aggregates for fibrin(ogen) and annexin A5 (Figure 5B). The labeling of both fibrin(ogen) and annexin A5 was markedly reduced in the presence of $\mathrm{CTI}$; and even more with JAQ1 mAb present, then leaving only single platelets and small platelet clusters at the collagen surface. With $\mathrm{CTI}$ or CTI/JAQ1, thrombus volume (per $1000 \mu \mathrm{m}^{3}$ ), as measured from fibrinogen staining, reduced from $143 \pm 22$ to $20.3 \pm 9$ or $5.9 \pm 1.8 \mu \mathrm{m}^{3}$, respectively. This was also clear from phase-contrast images taken at the end of perfusion: with CTI present, surface area coverage of thrombi on collagen reduced from $39 \%$ to $13 \%$, and it further reduced to $7 \%$ with CTI/JAQ1 (Figure 5C). Morphometric analysis of thrombus size showed that $\mathrm{CTI}$ and JAQ1 abolished the formation of large (fibrin-containing) aggregates, again leaving only single platelets and small clusters. In contrast, addition of FVIlai to wildtype blood did not affect thrombus formation. Importantly, platelet thrombi were only detected at sites of collagen coating; hence, no platelets or fibrin were present at uncoated coverslips (Figure 5C). Staining of the thrombi on coverslips for FXII showed marked fluorescence of the collagen fibers, but not of the platelet aggregates (data not shown).

Subsequent flow studies were carried out with blood from factor XII deficient mice. In comparison to wildtype blood, thrombus formation and platelet procoagulant activity (OG488-annexin A5 binding) were significantly reduced in the absence of FXII (Figure $6 \mathrm{~A})$. Only small aggregates were left that stained for annexin A5 at sites of contact with collagen (Figure 6B). Also fibrin formation was greatly reduced. A similar set of results was observed using $\mathrm{FXl}^{-/-}$blood: thrombus formation and PS exposure reduced to a similar degree as with $\mathrm{FXII}^{-/-}$blood (Figure 6).

Additional experiments showed that $\mathrm{CTI}$ or FVIlai did not further reduce thrombus formation with $\mathrm{FXII}^{-/-}$blood. Addition of CTI or FVIlai changed the surface area coverage of thrombi from $40.7 \pm 4.5 \%$ to $40.5 \pm 1.6 \%$ or $38.5 \pm 3.8 \%$; and slightly reduced surface area coverage by PS-exposing platelets from $12.2 \pm 4.6 \%$ to $9.6 \pm 4.6 \%$ or $8.3 \pm 0.7 \%$, respectively $(n=3-5)$. To determine whether remaining PS exposure was due to GPVIinduced platelet activation, the $\mathrm{FXII}^{-1-}$ blood was treated with blocking anti-GPVI mAb JAQ1. This resulted in elimination of large platelet aggregates, fibrin formation and PS exposure, although individual platelets still adhered (Figure 6A). Together, these results suggest that flow over collagen triggers the FXII-driven intrinsic pathway of coagulation 
A

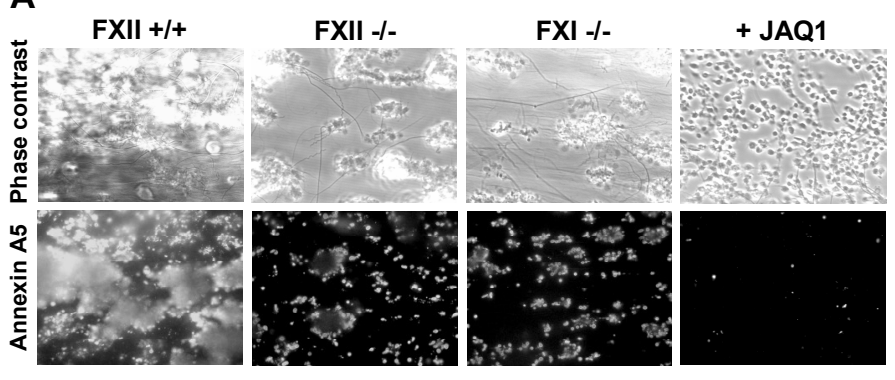

B
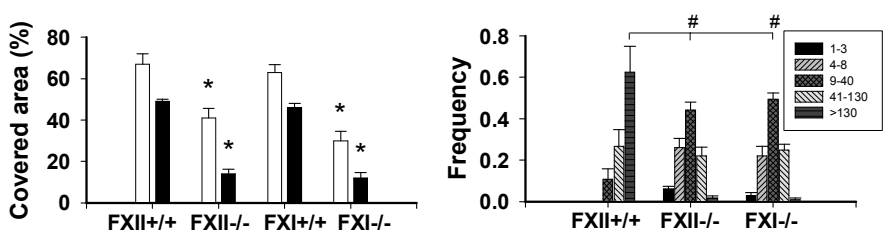

Figure 6. Deficiency in FXII or FXI impairs collagen-dependent formation of thrombi and clots. Blood from $\mathrm{FXII}^{-1-}$ or $\mathrm{FXI}^{-1-}$ mice or wildtypes was flowed over collagen under coagulant conditions for 4 minutes (see Figure 5). Thrombi were post-stained with OG488-annexin A5. Blood was pretreated with JAQ1 $\mathrm{mAb}(40 \mu \mathrm{g} / \mathrm{mL})$, as indicated. (A) Representative phase contrast and fluorescent images $(175 \times 225 \mu \mathrm{m})$. (B) Surface area coverage of thrombi (口) and PS-exposing platelets $(\square)$; lower panel shows frequency distribution of the feature sizes. Means \pm SEM $(n=5-7)$, *\# $p<0.05$ vs. corresponding wildtype (" for $\chi^{2}$ test).

and, thereby, promotes thrombus formation and PS exposure, under conditions where the tissue factor/FVIla pathway is inactive.

\section{Collagen-dependent thrombus formation and coagulation under flow also relies on platelet signaling by LAT and PLC ${ }^{2}$}

In flow-mediated thrombus formation on collagen type I fibers, GPVI-induced platelet activation causes PS exposure via signaling to the LAT adapter protein and PLC $\gamma 2$. With tissue factor present, this pathway strongly promotes the coagulation process. ${ }^{27}$ Mice heterozygously or homozygously deficient in LAT or PLC $\gamma 2$ were used to determine the contribution of GPVI signaling to the FXII-dependent coagulation pathway. To determine the activity of GPVI signaling, platelets from these mice were stimulated with collagen, PLC $\gamma 2$ was immunoprecipitated, and precipitates were assessed for tyrosine phosphorylation by western blot analysis. In comparison to wildtype platelets, tyrosine phosphorylation of PLC $\gamma 2$ was unchanged in platelets from heterozygous $\mathrm{LAT}^{+/-}$or PLC $\gamma 2^{+/-}$mice; however, it was markedly decreased by homozygous deficiency in LAT (Figure 7A). These results were confirmed by analysis of total collagen-induced tyrosine phosphorylation, giving a strong reduction in $\mathrm{LAT}^{-/}$and $\mathrm{PLC} \gamma 2^{-/-}$platelets but not in $\mathrm{LAT}^{+/-}$ and PLC $\gamma 2^{+/-}$platelets (not shown, but see Ref. ${ }^{30}$ ).

Flow experiments of recalcified blood (no tissue factor) from heterozygous $\mathrm{LAT}^{+/-}$and $\mathrm{PLC} \gamma 2^{+/-}$mice over collagen resulted in normal formation of large platelet/fibrin thrombi, 
A

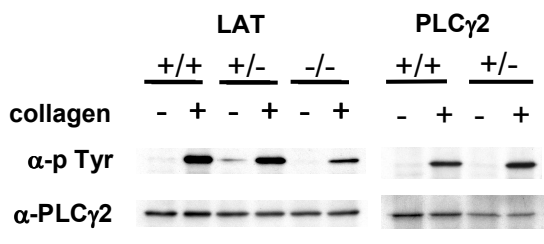

B
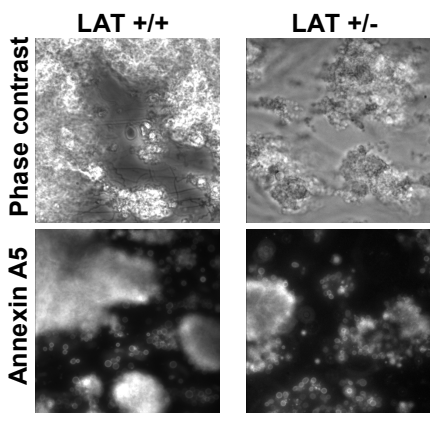

C

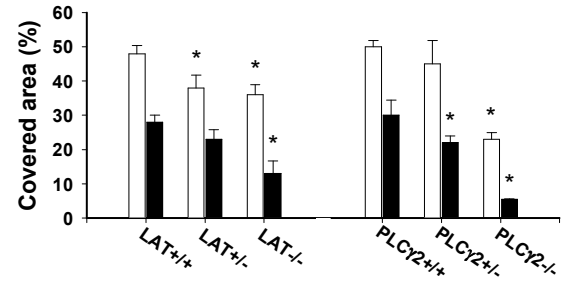

LAT -/-

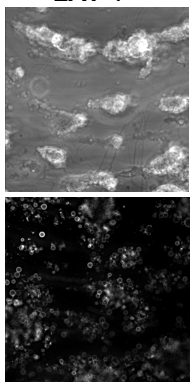

PLC $\gamma 2$-/-

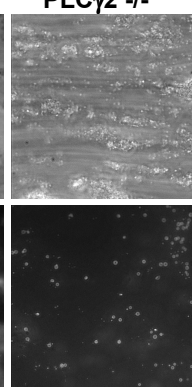

Figure 7. Deficiency in LAT or PLC $\boldsymbol{\gamma} 2$ impairs collagen-dependent thrombus formation and platelet procoagulant activity. (A) Effect of collagen type $1 / \mathrm{H}(10 \mu \mathrm{g} / \mathrm{mL})$ on tyrosine phosphorylation of PLC $\gamma 2$ in platelets from wildtype mice or mice (heterozygously) deficient in LAT or PLC $\gamma 2$. PLC $\gamma 2$ was immunoprecipitated, western blots were stained for antiphosphotyrosine (p-Tyr), then reprobed with anti-PLC $\gamma 2 \mathrm{mAb}$ (representative for 3 sample sets). (B) Blood from wildtype or deficient mice was flowed over collagen for 4 minutes; platelet-fibrin thrombi were post-stained with OG488-annexin A5 (see Figure 5). Shown are representative phase contrast and fluorescent images $(180 \times 180 \mu \mathrm{m})$. (C) Surface area coverage of thrombi ( $\square$ ) and PS-exposing platelets $(\mathbf{m})$. Means \pm SEM $(n=4-5),{ }^{*} p<0.05$ vs. corresponding wildtype.

again staining strongly for OG488-annexin A5 (Figure 7B). However, with blood from $\mathrm{LAT}^{-1-}$ mice, both thrombus formation and PS exposure were significantly, yet incompletely reduced in comparison to corresponding wildtype blood (Figure 7C). With PLC $\gamma 2^{-/-}$blood, large thrombi were no longer formed, while the collagen surface was covered with small platelet aggregates and a few single PS-exposing platelets. Essential the same results were obtained with blood from mice lacking the Fc receptor- $\gamma$ chain (not shown). Together, these results indicate that signaling to PLC $\gamma 2$ via LAT is essential for massive thrombus formation on collagen under conditions of flow and FXII-dependent coagulation.

Finally, to confirm the importance of this signaling pathway in collagen-dependent coagulation, thrombin generation experiments were performed using PRP from LAT ${ }^{-1}$ and PLC $\gamma 2^{-/-}$mice. In wildtype PRP, collagen $(5 \mu \mathrm{g} / \mathrm{mL})$ increased the thrombin peak height to $209 \pm 34 \%$ (mean \pm SEM, $n=4$ ), and this collagen effect was reduced to $114 \pm 9 \%$ or $127 \pm 7 \%$ in $\mathrm{LAT}^{-/-}$or PLC $\gamma 2^{-/-} \mathrm{PRP}$, respectively. In wildtype PRP, addition of CTI caused a partial reduction of the collagen effect to a peak height of $122 \pm 21 \%$ of the control value. In contrast, CTI did not change the collagen effect on thrombin peak in 
PRP from $\mathrm{LAT}^{-/-}(111 \pm 20 \%)$ or PLC $\gamma 2^{-/-}(106 \pm 14 \%)$ mice. Accordingly, collagenenhanced thrombin generation requires platelet stimulation via LAT and PLC $\gamma 2$ as well as FXII activation.

\section{Discussion}

In this paper we have defined a novel role for type I collagen by triggering the intrinsic pathway of coagulation via FXII and FXI activation; this pathway operates jointly with the platelet-stimulating effect of collagen via GPVI signaling. Evidence for this collagen function comes from data that collagen: a) shortens plasma clotting times in a FXIIdependent way; b) enhances thrombin generation via FXII, and c) stimulates flowdependent thrombus formation under coagulant conditions. These collagen effects are detected in both the presence and absence of platelets, and in human as well as mouse plasma systems. With platelets present, collagen has an additional effect by causing signaling via GPVI to activation of LAT and PLC $\gamma 2$. Earlier work has shown that GPVI activation causes a potent rise in cytosolic $\mathrm{Ca}^{2+}$ concentration and exposure of PS, which mediates platelet-dependent coagulant activity. ${ }^{14,26}$ The present data hence point to a second potentiating role of collagen in thrombus formation, by also triggering the contact-dependent coagulation system via FXII. This dual thrombogenic effect of collagen can explain why collagen exposure is such an efficient trigger for thrombus formation in many in vivo thrombosis models. ${ }^{2,31}$ From in vivo (staining) and in vitro studies it is already known that type I next to type III collagen is most thrombogenic.

Earlier work has demonstrated a key role of murine FXII and FXI in several models of experimental thrombosis. ${ }^{9,32}$ The present findings not only confirm this, but also provide a mechanistic explanation. The proposed scheme is that collagen activates FXII and FXI, which provides sufficient amounts of activated coagulation factors to start thrombin generation. Platelets exposing PS, also formed on collagen, then provide the necessary surface for propagation of the coagulation process. Our data indicate that such a process is operative under flow conditions, since the formation of thrombi composed of fibrin(ogen)-binding and PS-exposing platelets under flow was highly sensitive to blockage/absence of FXII or FXI and by blockage/absence of platelet GPVI activation. The similarity in effects of FXII and FXI deficiency is in agreement with in vivo measurements of murine thrombus formation. ${ }^{33}$ In line with this also is a recent study showing that in human plasma FXII is the main activator of $\mathrm{FXI}^{34}$

Blood and plasma can contain trace amounts of (blood-borne) tissue factor, which for instance has been identified at the surface of (activated) platelets. ${ }^{35,36}$ In the present experiments, tissue factor blocking with FVIlai had sometimes a small inhibitory effect, which however contrasted with the much larger inhibition by CTI or the absence of FXII. Hence, these results point to a strong role of the intrinsic coagulation pathway that is independent of tissue factor activity. Conversely, procoagulant effects of collagen - i.e. those independent of platelet activation - were not observed in the presence of picomolar concentrations of tissue factor. Together, this suggests that under physiological conditions the FXII-stimulating role of collagen becomes most relevant 


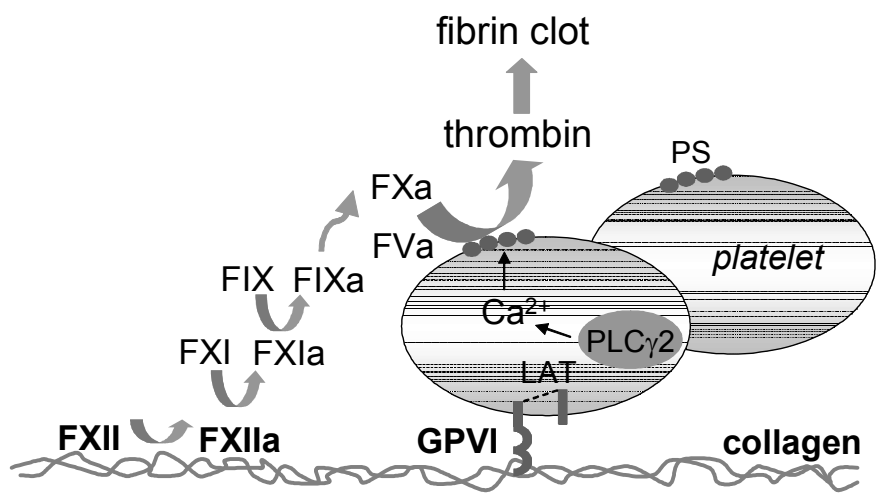

Figure 8. Proposed dual role of collagen in thrombus formation. Collagen binds and facilitates FXII activation, which results in sequential activation of FXI and FIX. Platelets adhere to collagen and are activated via their GPVI receptors. Subsequent signaling via LAT and PLC $\gamma 2$ results in $\mathrm{Ca}^{2+}$ mobilization and a PS-exposing membrane surface. This procoagulant surface allows formation of coagulation factor complexes for massive generation of FXa and thrombin. Jointly, these pathways lead to rapid formation of platelet-fibrin clots, under conditions where tissue factor is limitedly available.

when the local tissue factor activity is limited. While the role of platelets in particular is to provide a procoagulant membrane surface, our results do no exclude a contribution of other platelet-derived products, such as polyphosphates, to thrombus formation. ${ }^{37}$

The marked effects of type I collagens on the FXII-dependent clotting time and on thrombin generation suggested that collagen is capable to bind FXII and/or kininogen/prekallikrein. We indeed detected significant binding of FXII to fibrillar type I collagens, and this binding was not increased by kininogen/prekallikrein. Although the FXII binding site within the collagen sequence still needs to be identified, our results show that binding is accompanied by an enhanced activation of FXII in the presence of kininogen/prekallikrein.

Although the role of FXII in murine in vivo thrombosis models is well established, its relevance in clinical studies is equivocal. Several studies involving individuals with FXII levels within the broad normal range, report an association between low levels of FXII(a) and an increased risk on cardiovascular disease. ${ }^{19,38-40}$ However, the correlation was absent in individuals with FXII levels below $10 \%$ of normal. ${ }^{39}$ This indicates that is unclear whether low FXII levels are the cause or consequence of cardiovascular disease and therefore FXII may be more a risk marker than a risk factor. ${ }^{41}$ On the other hand, FXII deficiency is not related to bleeding, meaning that it is dispensable for normal hemostasis in both man and mice. Consequently, the intrinsic pathway of coagulation can be an attractive target for the treatment of thrombotic disease. ${ }^{33}$ While it still remains to be established how the protective effect of FXII deficiency in mice translates to the human situation, the present results yet lead to a better understanding of the mechanism of FXII activation.

In summary, the present results point to a dual role of exposed collagen in thrombus formation and coagulation (Figure 8). Collagen activates platelets via the GPVI-LAT- 
PLC $\gamma 2$ signaling pathway, causing platelet aggregation and exposure of procoagulant PS. In addition, collagen binds FXII and enhances its activation, which via FXI results in the activation of other coagulation factors. This function of collagen may serve to backup and enhance the extrinsic tissue factor/FVIla pathway. 


\section{References}

1. Mackman N. Role of tissue factor in hemostasis, thrombosis, and vascular development. Arterioscler Thromb Vasc Biol. 2004;24:1015-1022.

2. Nieswandt B, Watson SP. Platelet-collagen interaction: is GPVI the central receptor? Blood. 2003;102:449-461.

3. Tans G, Rosing J, Griffin JH. Sulfatide-dependent autoactivation of human blood coagulation factor XII (Hageman factor). J Biol Chem. 1983;258:8215-8222.

4. Hojima Y, Cochrane CG, Wiggins RC, Austen KF, Stevens RL. In vitro activation of the contact (Hageman factor) system of plasma by heparin and chondroitin sulfate $\mathrm{E}$. Blood. 1984;63:1453-1459.

5. Wilner GD, Nossel HL, LeRoy EC. Activation of Hageman factor by collagen. J Clin Invest. 1968;47:2608-2615.

6. Colman RW, Schmaier AH. Contact system: a vascular biology modulator with anticoagulant, profibrinolytic, antiadhesive, and proinflammatory attributes. Blood. 1997;90:3819-3843.

7. Zacharski LR, Rosenstein R. Failure of collagen to activate factor XII. Thromb Res. 1975;7:929-933.

8. Koenig JM, Chahine A, Ratnoff OD. Inhibition of the activation of Hageman factor (factor XII) by soluble human placental collagens types III, IV, and V. J Lab Clin Med. 1991;117:523-527.

9. Renné T, Pozgajova M, Gruner S, Schuh K, Pauer HU, Burfeind P, Gailani D, Nieswandt B. Defective thrombus formation in mice lacking coagulation factor XII. J Exp Med. 2005;202:271-281.

10. Kleinschnitz C, Stoll G, Bendszus M, Schuh K, Pauer HU, Burfeind P, Renné C, Gailani D, Nieswandt B, Renné T. Targeting coagulation factor XII provides protectin from pathological thrombosis in cerebral ischemia without interfering with hemostasis. J Exp Med. 2006;203:513-518.

11. Wang X, Cheng Q, Xu L, Feuerstein GZ, Hsu MY, Smith PL, Seiffert DA, Schumacher WA Ogletree ML, Gailani D. Effects of factor IX or factor XI deficiency on ferric chloride-induced carotid artery occlusion in mice. J Thromb Haemost. 2005;3:695-702.

12. Watson SP, Auger JM, McCarty OJ, Pearce AC. GPVI and integrin $\alpha$ llb $\beta 3$ signaling in platelets. J Thromb Haemost. 2005;3:1752-1762.

13. Massberg S, Gawaz M, Gruner S, Schulte V, Konrad I, Zohlnhofer D, Heinzmann U, Nieswandt B. A crucial role of glycoprotein VI for platelet recruitment to the injured arterial wall in vivo. J Exp Med. 2003;197:41-49.

14. Munnix IC, Strehl A, Kuijpers MJ, Auger JM, van der Meijden PE, van Zandvoort MA, oude Egbrink MG, Nieswandt B, Heemskerk JW. The glycoprotein VI-phospholipase C $\gamma 2$ signaling pathway controls thrombus formation induced by collagen and tissue factor in vitro and in vivo. Arterioscler Thromb Vasc Biol. 2005;25:2673-2678.

15. Nonne C, Lenain N, Hechler B, Mangin P, Cazenave JP, Gachet C, Lanza F. Importance of platelet phospholipase $\mathrm{C} \gamma 2$ signaling in arterial thrombosis as a function of lesion severity. Arterioscler Thromb Vasc Biol. 2005;25:1293-1298.

16. Heemskerk JW, Kuijpers MJ, Munnix IC, Siljander PR. Platelet collagen receptors and coagulation. A characteristic platelet response as possible target for antithrombotic treatment. Trends Cardiovasc Med. 2005;15:86-92.

17. Siljander P, Lassila R. Studies of adhesion-dependent platelet activation: distinct roles for different participating receptors can be dissociated by proteolysis of collagen. Arterioscler Thromb Vasc Biol. 1999;19:3033-3043.

18. Rosing J, Tans G, Govers-Riemslag JW, Zwaal RF, Hemker HC. The role of phospholipids and factor Va in the prothrombinase complex. J Biol Chem. 1980;255:274-283.

19. Govers-Riemslag JW, Smid M, Cooper JA, Bauer KA, Rosenberg RD, Hack CE, Hamulyak K, Spronk HM, Miller GJ, ten Cate H. The plasma kallikrein-kinin system and risk of cardiovascular disease in men. J Thromb Haemost. 2007;5:1896-1903. 
20. Wang D, Feng J, Wen R, Marine JC, Sangster MY, Parganas E, Hoffmeyer A, Jackson CW, Cleveland JL, Murray PJ, Ihle JN. Phospholipase $\mathrm{C} \gamma 2$ is essential in the functions of B cell and several Fc receptors. Immunity. 2000;13:25-35.

21. Zhang W, Sommers CL, Burshtyn DN, Stebbins CC, DeJarnette JB, Trible RP, Grinberg A, Tsay HC, Jacobs HM, Kessler CM, Long EO, Love PE, Samelson LE. Essential role of LAT in T cell development. Immunity. 1999;10:323-332.

22. Gailani D, Lasky NM, Broze GJ. A murine model of factor XI deficiency. Blood Coagul Fibrinolysis. 1997;8:134-144.

23. Pauer HU, Renne T, Hemmerlein B, Legler T, Fritzlar S, Adham I, Muller-Esterl W, Emons G, Sancken U, Engel W, Burfeind P. Targeted deletion of murine coagulation factor XII gene: a model for contact phase activation in vivo. Thromb Haemost. 2004;92:503-508.

24. van der Meijden PE, Feijge MA, Giesen PL, Huijberts M, van Raak EP, Heemskerk JW. Platelet $P 2 Y_{12}$ receptors enhance signaling towards procoagulant activity and thrombin generation: a study with healthy subjects and patients at thrombotic risk. Thromb Haemost. 2005;93:1128-1137.

25. van der Meijden PE, Schoenwaelder SM, Feijge MA, Cosemans JM, Munnix IC, Wetzker R, Heller R, Jackson SP, Heemskerk JW. Dual P2Y ${ }_{12}$ receptor signaling in thrombin-stimulated platelets - involvement of phosphoinositide 3-kinase $\beta$ but not $\gamma$ isoform in $\mathrm{Ca}^{2+}$ mobilization and procoagulant activity. FEBS J. 2008;275:371-385.

26. Vanschoonbeek K, Feijge MA, van Kampen RJ, Kenis H, Hemker HC, Giesen PL, Heemskerk JW. Initiating and potentiating role of platelets in tissue factor-induced thrombin generation in the presence of plasma: subject-dependent variation in thrombogram characteristics. J Thromb Haemost. 2004;2:476-484.

27. Munnix IC, Kuijpers MJ, Auger JM, Thomassen CM, Panizzi P, van Zandvoort MA, Rosing J, Bock PE, Watson SP, Heemskerk JW. Segregation of platelet aggregatory and procoagulant microdomains in thrombus formation. Regulation by transient integrin activation. Arterioscler Thromb Vasc Biol. 2007;27:2484-2490.

28. Marshall SJ, Asazuma N, Best D, Wonerow P, Salmon G, Andrews RK, Watson SP. Glycoprotein Ilb/Illa-dependent aggregation by glycoprotein Ib $\alpha$ is reinforced by a Src family kinase inhibitor (PP1)-sensitive signaling pathway. Biochem J. 2002;361:297-305.

29. Auger JM, Best D, Snell DC, Wilde JI, Watson SP. C-Cbl negatively regulates platelet activation by glycoprotein VI. J Thromb Haemost. 2003;1:2419-2426.

30. Judd BA, Myung PS, Obergfell A, Myers EE, Cheng AM, Watson SP, Pear WS, Allman D, Shattil SJ, Koretzky GA. Differential requirement for LAT and SIp76 in GPVI versus T cell receptor signaling. J Exp Med. 2002;195:705-717.

31. Nieswandt B, Brakebusch C, Bergmeier W, Schulte V, Bouvard D, Mohtari-Nejad R, Lindhout T, Heemskerk JWM, Zirngibl H, Fässler R. Glycoprotein VI but not $\alpha 2 \beta 1$ integrin is essential for platelet interaction with collagen. EMBO J. 2001;20:2120-2130.

32. Renné T, Nieswandt B, Gailani D. The intrinsic pathway of coagulation is essential for thrombus stability in mice. Blood Cells Mol Dis. 2006;36:148-151.

33. Gailani D, Renné T. The intrinsic pathway of coagulation: a target for treating thromboembolic disease? J Thromb Haemost. 2007;5:1106-1112.

34. Pedicord DL, Seiffert D, Blat $Y$. Feedback activation of factor $X I$ by thrombin does not occur in plasma. Proc Natl Acad Sci USA. 2007;104:12855-12860.

35. Giesen PL, Rauch U, Bohrman B, Kling D, Roqué M, Fallon JT, Badimon JJ, Himber J, Riederer MA, Nemerson Y. Blood-borne tissue factor, another view of thrombosis. Proc Natl Acad Sci USA. 1999;96:2311-2315.

36. Panes O, Matus V, Saez CG, Quiroga T, Pereira J, Mezzano D. Human platelets synthesize and express tissue factor. Blood. 2007;109:5242-5250.

37. Smith SA, Mutch NJ, Baskar D, Rohloff P, Docampo R, Morrissey JH. Polyphosphate modulates blood coagulation and fibrinolysis. Proc Natl Acad Sci USA. 2006;103:903-908. 
38. Doggen CJ, Rosendaal FR, Meijers JC. Levels of intrinsic coagulation factors and the risk of myocardial infarction among men: Opposite and synergistic effects of factors XI and XII. Blood. 2006;108:4045-4051.

39. Endler G, Marsik C, Jilma B, Schickbauer T, Quehenberger P, Mannhalter C. Evidence of a U-shaped association between factor XII activity and overall survival. J Thromb Haemost. 2007;5:1143-1148.

40. Bach J, Endler G, Winkelmann BR, Boehm BO, Maerz W, Mannhalter C, Hellstern P. Coagulation factor XII (FXII) activity, activated FXII, distribution of FXII C46T gene polymorphism and coronary risk. J Thromb Haemost. 2008;6:291-296.

41. Kanaji T. Lower factor XII activity is a risk marker rather than a risk factor for cardiovascular disease: a rebuttal. J Thromb Haemost. 2008;6:1053-1054. 
General discussion 
Thrombosis as well as hemostasis rely on platelet activation and on fibrin clot formation by activation of the coagulation cascade. In the classical concept, platelets stimulate the coagulation process when activated by the combination of thrombin and collagen. Together, these agonists induce exposure of phosphatidylserine (PS) at the platelet surface, which mediates the local assembly and activation of coagulation factors provoking activation of factor $\mathrm{X}$ and prothrombin. ${ }^{1}$ In earlier work, this procoagulant effect of platelet activation in response to thrombin and collagen could be linked to signaling via the PAR1/4 and glycoprotein VI receptors, respectively. ${ }^{2,3}$ However, given the extensive interplay of platelet activation and coagulation, it is quite likely that also other platelet agonists than thrombin and collagen, and other sets of platelet receptors, regulate the development of platelet procoagulant activity. This was the underlying hypothesis of the present thesis, where we aimed to study new interaction mechanisms of platelet signaling and coagulation. The results show a novel role of ADP signaling via the $P 2 Y_{12}$ receptor in the stimulation of PS exposure. Furthermore, we describe that also outside-in signaling by integrin $\alpha$ llb $\beta 3$ leads to stimulation of platelet procoagulant activity. Third, we report on an additional role of collagen by enhancing the factor XII pathway of coagulation in the stimulation of platelet-dependent thrombus formation. These findings may identify new antithrombotic targets for remedying cardiovascular diseases.

\section{$\mathrm{P} \mathrm{Y}_{12}$ signaling pathways leading to procoagulant activity}

The role of $A D P$ and its receptors, $P 2 Y_{1}$ and $P 2 Y_{12}$, in platelet aggregation is well established. Chapters 3 and 4 of this thesis describe that ADP receptor stimulation also has another role, namely enhancement of platelet procoagulant activity. This appeared from the ability of ADP to enhance thrombin generation in coagulating plasma. The data show that ADP, produced by platelets in an autocrine way, is responsible for a considerable part of the thrombin-induced exposure of procoagulant phosphatidylserine (PS) at the platelet surface. In addition, co-stimulation of platelets with ADP and thrombin further enhances the PS exposure. Thus, in thrombin-stimulated platelets ADP release provides a positive feedback loop by enhancing PS exposure and thereby the process of thrombin generation. These observations are in general agreement with those of other studies. $^{4-6}$

As thrombin is always present at sites of vascular injury, it was of interest to study the synergistic effects of ADP and thrombin in more detail. By using specific antagonists of the $\mathrm{P}_{2} \mathrm{Y}_{1}$ and $\mathrm{P}_{2} \mathrm{Y}_{12}$ receptors, it appeared that the synergistic effect of ADP on the activation of platelets by thrombin relies exclusively on $\mathrm{P} 2 \mathrm{Y}_{12}$ receptor function. In further experiments, we unraveled the signaling pathways downstream of the $\mathrm{P}_{2} \mathrm{Y}_{12}$ receptor that are responsible for the enhanced PS exposure and subsequent thrombin generation. Background knowledge was that platelet PS exposure is considered to be the result of a prolonged elevation in cytosolic free $\mathrm{Ca}^{2+}$ level. Further, it is known that $\mathrm{P}^{2} \mathrm{Y}_{12}$ signaling does contribute to the ADP-induced $\mathrm{Ca}^{2+}$ response. $^{7}$ In Chapter 3 it is shown that this $\mathrm{P}_{2} \mathrm{Y}_{12}$ signal is relevant even in the presence of the potent platelet activator thrombin. Since the thrombin receptor PAR4 also prolongs the $\mathrm{Ca}^{2+}$ response, it 
was important to compare the contribution of $\mathrm{P}_{2} \mathrm{Y}_{12}$ activation to this response in platelets stimulated with PAR1 agonist alone or with a combination of PAR1 and PAR4 agonists. In either case, $\mathrm{P}_{2} \mathrm{Y}_{12}$ inhibition resulted in a quite similar reduction of the $\mathrm{Ca}^{2+}$ signal in platelets. Hence it was concluded that upon thrombin stimulation, particularly PAR1 signaling synergizes with $\mathrm{P}_{2} \mathrm{Y}_{12}$ in prolonged $\mathrm{Ca}^{2+}$ elevation.

Subsequent work presented in Chapter 4 indicated that the $\mathrm{P}_{2} \mathrm{Y}_{12}$-dependent effect involves two parallel signaling pathways. This is summarized in Figure 1. On the one hand, $\mathrm{P}_{2} \mathrm{Y}_{12}$ inhibits adenylyl cyclase activity via $\mathrm{Gi}$, which suppresses cAMP-dependent protein kinase $A(P K A)$ activation. This protein kinase can phosphorylate and thereby inactivate the platelet inositol 1,4,5-triphosphate $\left(\mathrm{IP}_{3}\right)$ receptors. ${ }^{8}$ It is known that epinephrine, which inhibits adenylyl cyclase via Gz, antagonizes the PKA-dependent phosphorylation and inactivation of $\mathrm{IP}_{3}$ receptors, and hence increases the $\mathrm{IP}_{3}$ receptormediated $\mathrm{Ca}^{2+}$ release from intracellular stores. ${ }^{9}$ By analogy, the results in Chapter 4 indicate that $\mathrm{P}_{2} \mathrm{Y}_{12}$-induced inhibition of $\mathrm{PKA}$ also increases $\mathrm{Ca}^{2+}$ mobilization from internal stores. The second $\mathrm{P}_{2} \mathrm{Y}_{12}$-dependent signaling pathway again acts via $\mathrm{Gi}$, but not via adenylyl cyclase. This pathway appears to be mediated by activation of phosphoinositide 3-kinase (PI3-K), which produces phosphatidylinositol 3,4,5 triphosphate $\left(\mathrm{PIP}_{3}\right)$ and increases the activation of phospholipase $\mathrm{C}$ isoforms. The

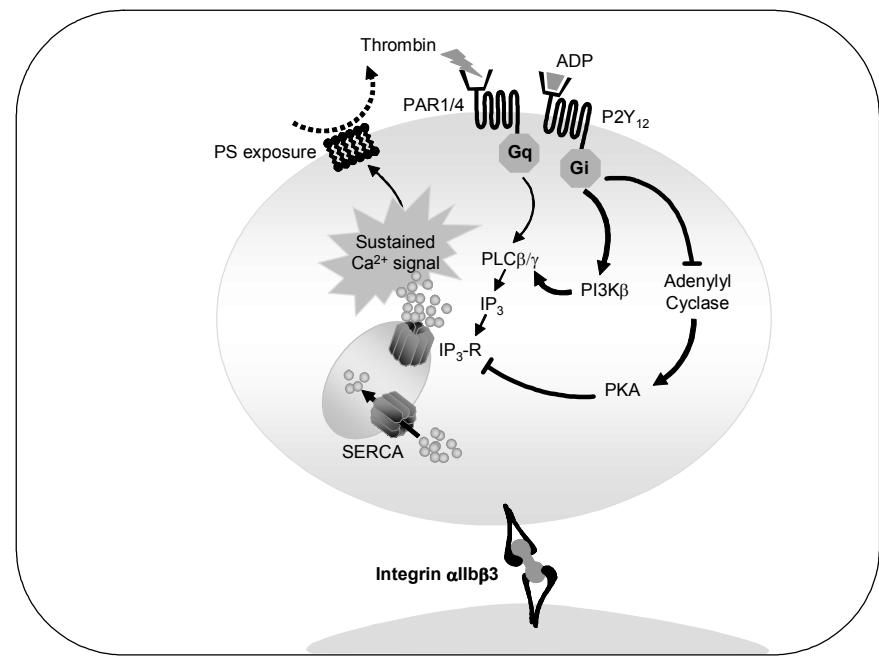

Figure 1. Synergy of platelet signaling induced by $P 2 Y_{12}$ and thrombin receptors. Thrombin receptors (PAR1/4) couple to Gq. This leads to phospholipase $C \beta$ (PLC $\beta$ ) activation, $\mathrm{IP}_{3}$ formation and $\mathrm{Ca}^{2+}$ release from intracellular stores. Autocrine produced ADP binds to the $\mathrm{P} 2 \mathrm{Y}_{1}$ and $\mathrm{P} 2 \mathrm{Y}_{12}$ receptors. $\mathrm{P} 2 \mathrm{Y}_{1}$ also couples to $\mathrm{Gq}$, but this effect is overruled by thrombin signaling. In contrast, $P 2 Y_{12}$ activates $\mathrm{Gi}$ and prolongs the thrombin-induced $\mathrm{Ca}^{2+}$ response via two pathways. First, it increases $\mathrm{IP}_{3}$ receptor function via PKA inhibition. Second, it activates phosphoinositide 3-kinase (PI3-K) which results in phospholipase $\mathrm{C}(\gamma)$ activation and extended $\mathrm{IP}_{3}$ formation. Thus $\mathrm{P}_{2} \mathrm{Y}_{12}$ prolongs the mobilization of $\mathrm{Ca}^{2+}$ and this sustained $\mathrm{Ca}^{2+}$ signal will result in PS exposure and subsequent thrombin formation at the platelet surface. For further details, see text. 
consequence is an increase and extension of the production of $\mathrm{IP}_{3}$ and, consequently, a prolongation of the $\mathrm{Ca}^{2+}$ signal. By which molecular mechanism $\mathrm{PI}-\mathrm{K}$ becomes activated via $\mathrm{Gi}$ is still unknown.

The following data sets confirmed this dual model of $P 2 Y_{12}$ signaling via adenylate cyclase inhibition and PI3-K activation: a) combined inhibition of PKA and PI3-K was needed to antagonize the prolonged $\mathrm{P}_{2} \mathrm{Y}_{12}$-induced $\mathrm{Ca}^{2+}$ response; $b$ ) $\mathrm{IP}_{3}$ receptor function, which is affected by PKA activation, became increased in the presence of ADP and this increase was abolished by inhibition of $\mathrm{P}_{2} \mathrm{Y}_{12}$ but not of $\mathrm{PI}-\mathrm{K}$; $c$ ) phospholipase $\mathrm{C}$ inhibition, in a similar way as $\mathrm{PI}-\mathrm{K}$ blockage, reduced the prolonged phase of the $\mathrm{Ca}^{2+}$ response; and $d$ ) phospholipase $\mathrm{C}$-dependent $\mathrm{IP}_{3}$ formation was decreased upon $\mathrm{PI} 3-\mathrm{K}$ blockage. In support of these results, others have demonstrated that P2Y 12 can potentiate the $\mathrm{P} 2 \mathrm{Y}_{1}$-induced $\mathrm{Ca}^{2+}$ response via inhibition of adenylyl cyclase and activation of $\mathrm{PI} 3-\mathrm{K}^{10}{ }^{10}$ These authors also reported that Src kinases negatively regulate the PI3-K-dependent pathway of $\mathrm{P}_{2} \mathrm{Y}_{12}$. In this thesis, we could not confirm such a role for Src kinases in $\mathrm{P}_{2} \mathrm{Y}_{12}$ signaling with thrombin present. Furthermore, we found that thrombin overruled effects of $\mathrm{P}_{2} \mathrm{Y}_{1}$ on the $\mathrm{Ca}^{2+}$ response, most likely because thrombin receptors similarly as $P 2 Y_{1}$ signal via the $G q$ and $G 13$ proteins. Confirmative evidence that the procoagulant effect of ADP proceeds via the two above-mentioned $\mathrm{P}_{2} \mathrm{Y}_{12}$ mediated pathways came from thrombin generation experiments. Here all stimulatory effects of ADP were abolished in the combined presence of PKA and PI3-K inhibitors.

Platelets contain a number of class I isoforms of PI3-K, namely $\alpha, \beta, \delta$ and $\gamma \cdot{ }^{11}$ It is nowadays well established that the $\mathrm{PI} 3-\mathrm{K} \beta$ and $\mathrm{PI} 3-\mathrm{K} \gamma$ isoforms play a role in integrin $\alpha$ llb $\beta 3$ activation and hence in the stabilization of platelet aggregation. ${ }^{12,13}$ By using platelets from mice deficient in $\mathrm{PI}-\mathrm{K} \gamma$ and using isoform-specific inhibitors directed against the catalytic subunit of PI3-K, we investigated which isoform is involved in the prolonged $\mathrm{Ca}^{2+}$ response and procoagulant activity downstream of $\mathrm{P} 2 \mathrm{Y}_{12}$. Selective inhibition of $\mathrm{PI} 3-\mathrm{K} \beta$ reduced the $\mathrm{Ca}^{2+}$ response and $\mathrm{PS}$ exposure following platelet stimulation with thrombin/ADP. However, platelets from mice deficient in $\mathrm{PI} 3-\mathrm{K} \gamma$ or platelets treated with $\mathrm{PI}-\mathrm{K} \gamma$ inhibitor were unchanged in $\mathrm{Ca}^{2+}$ response and procoagulant activity. This is in contrast with a report by Lian et al. showing a mildly impaired $\mathrm{Ca}^{2+}$ response with ADP or thrombin in platelets from mice deficient in PI3-K $\gamma .{ }^{14}$ However, the response was further suppressed by the general PI3-K inhibitor, LY294002, which is compatible with our finding that mainly PI3-K $\beta$ is contributing to the $\mathrm{Ca}^{2+}$ response downstream of $\mathrm{P} 2 \mathrm{Y}_{12}$. Once mice lacking $\mathrm{PI} 3-\mathrm{K} \beta$ become available, it will be important to confirm the key importance of this $\mathrm{PI}-\mathrm{K}$ isoform in platelet procoagulant activity.

Another novel observation presented in Chapter 4 is that the PI3-K $\beta$ isoform is fully responsible for phosphorylation of the downstream target Akt1/2 (protein kinase $B$ ). Interestingly, we did not find evidence for a role of PI3-K $\gamma$ herein, such as proposed by others. $^{15}$ Our data are in agreement with other studies, showing that in thrombinstimulated platelets the phosphorylation and activation of Akt is completely dependent on autocrine ADP release and on $\mathrm{P}_{2} \mathrm{Y}_{12}$ activity. ${ }^{16-18}$ Accordingly, most studies stipulate that Akt is activated downstream of $\mathrm{Gi}\left(\mathrm{P} 2 \mathrm{Y}_{12}\right)$ and not $\mathrm{Gq}\left(\mathrm{P} 2 \mathrm{Y}_{1}, \mathrm{PARs}\right)$. 
In cell types other than platelets, the $\mathrm{PIP}_{3}$ formed by $\mathrm{PI} 3-\mathrm{K}$ activity plays a role in the docking and activation of $\mathrm{PH}$ domain-containing phospholipase $\mathrm{C} \gamma$ and Akt isoforms to the plasma membrane. ${ }^{19}$ Given the evidence, described above, that also in platelets $\mathrm{PI} 3-$ $\mathrm{K}$ activity increases phospholipase $\mathrm{C}$ activation and enhances $\mathrm{Ca}^{2+}$ signaling, a similar docking mechanism may be applicable for the ADP/P2Y 12 activation pathway. This would imply an involvement of phospholipase $\mathrm{C} \gamma$ in this pathway, since it contains $\mathrm{PH}$ domains for interaction with $\mathrm{PIP}_{3}$, such in contrast to the $\mathrm{G}$ protein-coupled phospholipase $\mathrm{C} \beta$ isoforms. There is early evidence that thrombin stimulation leads to activation of the phospholipase $C_{\gamma} 1$ isoform; ${ }^{20}$ based on the present results it is likely that this thrombin effect relies on autocrine production of $A D P$ and $P 2 Y_{12}$ signaling.

Following PI3-K activation, the formed $\mathrm{PIP}_{3}$ has been shown to lead to membrane attachment and phosphorylation of platelet Akt. ${ }^{21}$ Although studies with mouse platelets have demonstrated the importance of Akt in platelet aggregation, fibrinogen binding and granule secretion, ${ }^{18,22}$ it is has not been investigated whether Akt isoforms play a role in the procoagulant response (PS exposure) of platelets. Until recently, not much was known about the actual effectors of Akt. A newly discovered target is GSK3ß, which is phosphorylated by Akt, and then acts as a positive regulator of platelet function. ${ }^{23}$ Thus, if GSK3 $\beta$ indeed appears to be the main effector of Akt in platelets, it may play a role in the $\mathrm{P} 2 \mathrm{Y}_{12}$-mediated procoagulant response.

\section{Function of integrin $\alpha$ llb $\beta 3$ outside-in signaling in procoagulant activity}

In addition to mediating platelet aggregation, integrin $\alpha$ llb $\beta 3$ must play a role in platelet procoagulant activity, as various groups describe that $\alpha \mathrm{llb} \beta 3$ antagonists suppress thrombin generation in platelet-rich plasma. ${ }^{24-27}$ However, besides the proposal that $\alpha \mathrm{llb} \beta 3$ may act as a receptor for prothrombin, ${ }^{28}$ little was known about the precise action mechanism of these integrin blockers. We reasoned that this inhibiting effect implicates that the blockers interfere with the binding of fibrinogen to activated $\alpha$ llb $\beta 3$ and, hence, with so-called outside-in signaling evoked by this integrin. Therefore we investigated whether and how $\alpha \mathrm{llb} \beta 3$ outside-in signaling affects platelet procoagulant activity. Chapter 5 gives supportive evidence for this concept. It appeared that fibrinogendependent outside-in signaling via $\alpha$ llb $\beta 3$ promotes a late phase of the $\mathrm{Ca}^{2+}$ response induced by strong agonists, which results in a significant enhancement of PS exposure. Strikingly, integrin $\alpha \mathrm{llb} \beta 3$ antagonists did not affect the initial $\mathrm{Ca}^{2+}$ response $(<5 \mathrm{~min}$ after activation), but markedly reduced the $\mathrm{Ca}^{2+}$ level in a later phase. The experiments with $\alpha$ llb $\beta 3$ antagonists were confirmed by using platelets from a Glanzmann patient, which lack functional integrin $\alpha$ llb $\beta 3$. The patient's platelets showed reduced $\mathrm{Ca}^{2+}$ signaling paralleled by a decreased PS exposure.

There is limited literature, reviewed elsewhere ${ }^{29}$ indicating that the pathway of $\alpha$ llb $\beta 3$ outside-in signaling is reminiscent to that evoked by glycoprotein $\mathrm{VI}$, which potently causes PS exposure. Clustering of $\alpha \mathrm{llb} \beta 3$ caused by fibrinogen binding leads to activation of Src kinase and recruitment of Syk kinase. ${ }^{30}$ Since phospholipase $\mathrm{C} \gamma 2$ is a 


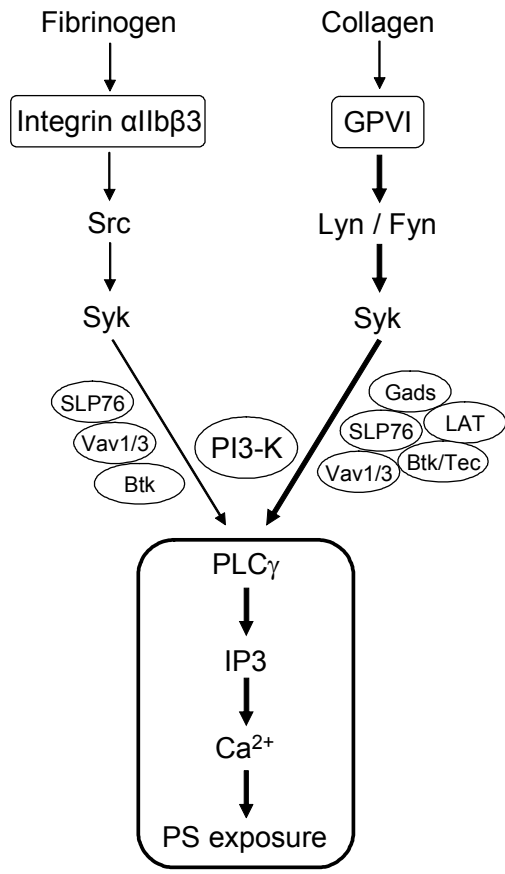

Figure 2. Pathway of integrin $\alpha \mathrm{llb} \beta 3$ outside-in signaling leading to enhanced PS exposure in activated platelets. Fibrinogen binding to integrin $\alpha$ llb $\beta 3$ prolongs the $\mathrm{Ca}^{2+}$ signal in activated platelets most probably via activation of phosphoinositide 3-kinase (PI3-K) and a phospholipase C $\gamma$ (PLC $\gamma$ ) isoform. This proposed pathway shows resemblance to the glycoprotein VI (GPVI) pathway induced by collagen. Outside-in signaling via $\alpha$ llb $\beta 3$ thereby enforces PS exposure in (thrombin) activated platelets.

substrate of Src kinase, it is proposed that this kinase, together with Syk and Btk kinases and the signaling components SLP76 and Vav, phosphorylates and activates phospholipase $\mathrm{C} \gamma 2$ downstream of $\alpha \mathrm{llb} \beta 3$ (Figure 2). ${ }^{29}$ This integrin pathway distinguishes from the glycoprotein VI pathway by not including the adaptor proteins LAT and Gads. ${ }^{29}$ It is unclear why. In addition, the results presented in Chapter 5 show that integrin $\alpha$ llb $\beta 3$ enhances PS exposure via PI3-K activation, which is only partly dependent on ADP secretion and subsequent $P 2 Y_{12}$ receptor activity. A similar mechanism as discussed above can be applied here; PI3-K-dependent formation of $\mathrm{PIP}_{3}$ leads to activation of phospholipase $\mathrm{C} \gamma$ with $\mathrm{Ca}^{2+}$ mobilization as a result (Figure 2). However, it remains to be determined how the integrin-mediated late $\mathrm{Ca}^{2+}$ response is influenced by PI3-K. Together, we demonstrated that the stimulating effect of glycoprotein $\mathrm{VI}$ and thrombin receptor activation on PS exposure is enforced by outsidein signaling via $\alpha$ llb $\beta 3$, likely through synergistic activation of phospholipase $\mathrm{C} \gamma$ (Figure 2).

A recent paper describes that $\alpha$ llb $\beta 3$ blockade might inhibit platelet PS exposure by potentiating phospholipid translocase and attenuating scramblase activity, although no mechanistic explanation for this observation was given. ${ }^{31}$ It is difficult to speculate on an 
integrin-mediated regulation of scramblase activity at present, since the putative enzyme involved is still unknown. Current attention focus on the actin cytoskeleton-binding proteins, talin and kindlin-3, which bind to the $\beta$-integrin tails and play an important role in allb $\beta 3$-dependent outside-in signaling. ${ }^{32-34}$ Whether and how these proteins are implicated in the platelet procoagulant response requires further study.

These $\alpha$ llb $\beta 3$-mediated outside-in signaling effects on procoagulant activity may interfere or overlap with the procoagulant effects of $\mathrm{P}_{2} \mathrm{Y}_{12}$ stimulation as described above. Because this ADP receptor potently activates $\alpha$ llb $\beta 3$, it can be hypothesized that subsequent integrin outside-in signaling adds to the $\mathrm{P}_{2} \mathrm{Y}_{12}$-mediated PS exposure. In Chapter 4 it is shown that $\alpha$ llb $\beta 3$ blockers do not influence the (initial) P2Y 12 -dependent $\mathrm{Ca}^{2+}$ signal, which seems to preclude a contribution of outside-in signaling. However, it should be noted that integrin effects on the late $\mathrm{Ca}^{2+}$ response were not assessed in this chapter.

Integrin $\alpha$ llb $\beta 3$ is a relatively often used target for antithrombotic therapy. Currently, three $\alpha$ llb $\beta 3$ antagonists have been approved for clinical application, i.e. the chimeric antibody abciximab, and the small molecules, eptifibatide and tirofiban. However, their clinical use is restricted due to limitations in efficacy leading to increased mortality and adverse effects of bleeding. ${ }^{35,36}$ These antagonists have proved benefits in patients undergoing percutaneous coronary intervention and in high risk patients with acute coronary syndromes. An explanation for the insufficient safety of $\alpha \mathrm{llb} \beta 3$ blockers is that they might act as ligand-mimetics by resembling the RGD sequence of fibrinogen and, hence, cause a conformational change of $\alpha$ llb $\beta 3$ followed by outside-in signaling. ${ }^{37-39}$ As a 'milder' integrin blocker, single-chain antibodies have been developed that bind specifically to the activated form of $\alpha$ llb $\beta 3$. This activation-specific blockade of integrin $\alpha$ llb $\beta 3$ does neither induce conformational changes nor outside-in signaling and reduces bleeding complications. ${ }^{40}$ In the perspective of this thesis, where we show that $\alpha$ llb $\beta 3$ is not only essential for platelet aggregation but also for procoagulant activity and hence coagulation, this dual function of $\alpha \mathrm{llb} \beta 3$ may provide an explanation for the bleeding complications caused by high levels of $\alpha \mathrm{llb} \beta 3$ inhibitors.

\section{Roles of collagen and factor XII in thrombus formation}

Collagen, exposed in damaged vessels, activates platelets via the glycoprotein VI receptor, which effectively leads to procoagulant activity (PS exposure). ${ }^{3}$ Old data suggested that collagen by itself can activate the coagulation system, perhaps via the contact activation pathway involving factor XII. ${ }^{41}$ However, these data were not uniformly supported and appeared to be dependent on the collagen preparation used. ${ }^{42}$ In the later literature, the increased procoagulant activity with collagen was supposed to be a platelet-dependent phenomenon. ${ }^{43}$ In Chapter 6 it is shown that type I collagen fibers markedly enhance thrombin generation and shorten the clotting time independently of platelets under conditions where tissue factor activity is limited. Typically, corn trypsin inhibitor, which is a specific blocker of factor XII activity, abolishes this stimulating effect of collagen both in the presence and absence of platelets. Complementary results were 
obtained with mice deficient in factor XII. In plasma from these mice, the stimulating effect of collagen on thrombin and clot formation has largely disappeared, and corn trypsin inhibitor is no longer effective. Together, this indicates that collagen stimulates the intrinsic pathway of coagulation via activation of factor XII. Supportive evidence comes from fluorescence experiments demonstrating the binding of labeled factor XII to collagen fibers. Furthermore, enzymatic studies showed that collagen enhanced the cleavage of a specific chromogenic substrate for activated factor XII in reaction mixtures where the presence of factor XII, prekallikrein and high molecular weight kininogen is required.

By using a flow model where shear-dependent thrombus formation was induced under coagulant conditions, it was shown that in the absence of factor XII smaller and instable thrombi were formed. Evidence for the physiological relevance of these findings was provided by the study of Renné et al., who show defective thrombus formation in mice lacking factor XII by means of three in vivo models of arterial thrombosis. ${ }^{44,45}$ With the present results, we have identified collagen as a key initiator of factor XII-driven thrombin formation. Note that this function is dependent on the availability of tissue factor, since with high (picomolar) tissue factor concentrations thrombus and clot formation are no longer limited in the absence of factor XII activation and, hence, are driven by the faster onset of the extrinsic coagulation pathway.

In addition, collagen has a well-known second function in thrombus formation, i.e. by providing a surface for platelet adhesion and activation through glycoprotein $\mathrm{VI}^{46}$ In blood from mice lacking LAT or phospholipase $\mathrm{C} \gamma 2$, we made the novel observation that GPVI signaling synergizes with the collagen-induced activation of factor XII for optimal thrombus and clot formation. Autocrine ADP/P2Y ${ }_{12-}$ and $\alpha$ llb33-dependent effects will enforce this process (see above). Another way, via which activated platelets can promote the contact activation pathway is by releasing polyphosphates, ${ }^{47}$ but this was not investigated.

In several in vivo mouse thrombosis models (e.g., using ligation-induced and ferric chloride-induced injury) collagen exposure is known to be a determining factor in the thrombus-forming process. Also in these in vivo models collagen was found to activate platelets via the glycoprotein VI pathway, as evidenced by experiments with mice lacking glycoprotein $\mathrm{VI}$, the FcR $\gamma$-chain or one of the downstream signaling proteins. ${ }^{48-52}$ However, the collagen dependency of these in vivo models suggests that the factor XII pathway of coagulation may also play a role herein. Indeed, defective thrombus formation in factor XII-deficient mice was detected in all in vivo models known to be dependent on collagen exposure. ${ }^{44}$

It should be noted that a number of other in vivo thrombosis models rely more strongly on tissue factor activity, particularly those using laser-induced and Bengal roseinduced injury. ${ }^{51}$ In these models it has been reported that thrombin inhibition is more effective than glycoprotein VI blockage. ${ }^{53}$ This is compatible with the present in vitro results indicating that under such conditions factor XII plays only a minor role, as it is overruled by the presence of tissue factor. Tissue factor is located in the (damaged) vessel wall, but it is also detected on microparticles and leukocytes in the circulating 


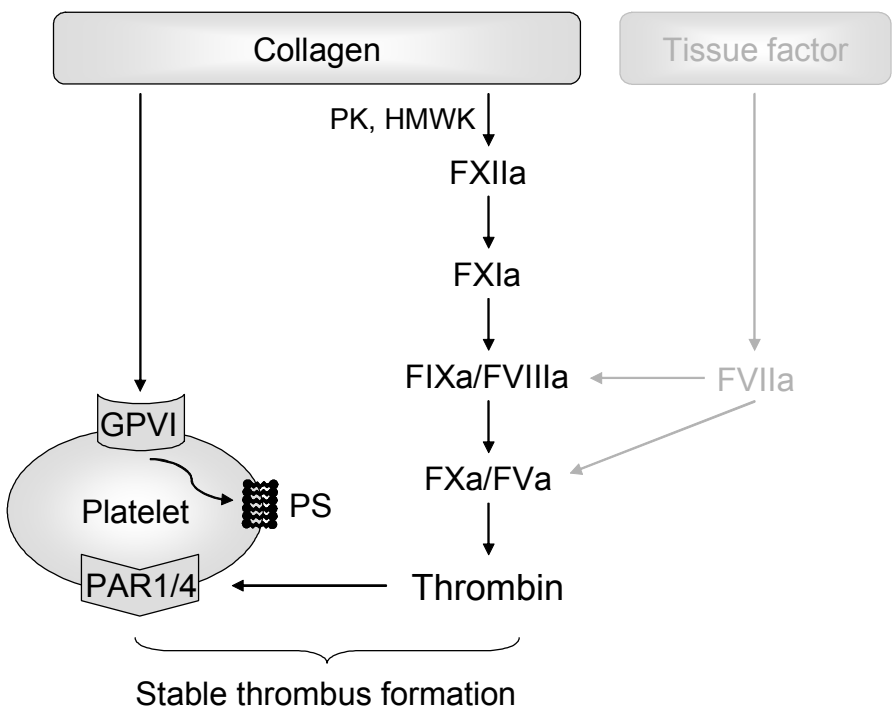

Figure 3. Dual role of collagen in coagulation-dependent thrombus formation. Upon vascular damage exposed collagen activates platelets via glycoprotein VI (GPVI) and thereby induces surface exposure of PS. Under conditions where tissue factor is limited, collagen additionally stimulates factor XII activation and triggers the intrinsic pathway of coagulation. Formation of thrombin is propagated at the PS-exposing platelet surface and both pathways are needed for optimal thrombus and clot formation. See text for further details.

blood. ${ }^{54}$ In the experiments presented in Chapter 6 circulating tissue factor did not appear to play a significant role, as evidenced by the limited effect of factor VIla inhibition on thrombus formation and thrombin generation. Recently, it was postulated that platelets can bind tissue factor in a way cross-linked by protein disulfide isomerase, likely at sites of high vascular damage ${ }^{55-57}$ On the other hand, platelets are known to release high amounts of tissue factor pathway inhibitor. ${ }^{58}$ Together, this suggests that the relative role of collagen and thus factor XII is depending on both the type and the severity of vascular injury and, perhaps, the platelet activation state. Obviously, in vivo experimentation is needed to confirm this.

As summarized in Figure 3, the data of this thesis (Chapter 6) indicate that collagen has two functions in the formation of thrombin and stable thrombi. It makes platelets procoagulant by activating the glycoprotein $\mathrm{VI}$ signaling pathway and, under conditions where tissue factor is limited or inhibited, collagen supports factor XII activation and triggers the intrinsic pathway of coagulation. In this scheme, the relative availability of collagen and tissue factor thus determines whether thrombin is generated via factor XII or via factor VII.

Although factor XII appears to play an important role in several mouse thrombosis models, and there is no evidence that this factor acts differently in mice and man, ${ }^{44}$ clinical studies are not unambiguous on its (patho)physiological function. ${ }^{59}$ There is conflicting evidence regarding the function of human factor XII in arterial thromboembolic disease, most likely due to heterogeneity between the patients with factor XII deficiency. 
Recent studies debate whether increased or decreased levels of plasma factor XII or XIla contribute to the risk of cardiovascular disease. ${ }^{60,61}$ Likely the new evidence with mouse models will stimulate further clinical studies. Considering that venous thrombi consist of predominantly red blood cells and fibrin and relatively little platelets (Chapter 2 ), it is likely that coagulation factor deficiencies have an impact on the risk of venous thrombosis. But also for venous thromboembolic disease, the role of factor XII is indistinct. $^{59}$

Factor XII activation sequentially cleaves and activates factor XI. Chapter 6 shows that the stimulating effect of collagen on thrombin formation requires the presence of factor XI. Furthermore, shear-dependent thrombus formation with blood from factor XI deficient mice is decreased to a similar extent as with factor XII deficient blood. This is compatible with in vivo evidence that factor XI and factor XII deficient mice are comparably protected from arterial or venous occlusion. ${ }^{44,62,63}$ Together this raises the possibility that, in mice, factor XII exerts all or most of its procoagulant effect via activation of factor XI. A striking difference with man is that the phenotypes of factor XIIand $\mathrm{XI}$-deficient mice are highly similar with no abnormality of hemostasis, whereas factor XI-deficient, but not factor XII-deficient patients, experience a mild bleeding disorder. Species differences can be an explanation for this. An alternative explanation concerns the factor XII-dependent formation of kininogen hydrolysis products, which have anticoagulant effects. ${ }^{64,65}$ Thus factor XII-deficient individuals lack both procoagulant and anticoagulant effects, while factor $\mathrm{XI}$-deficient individuals only lack the procoagulant component what possibly results in a bleeding tendency. ${ }^{64}$ In contrast to factor XII, various studies do address a clear association between high factor XI plasma levels and increased risk of arterial/venous thrombosis in humans. ${ }^{59}$

\section{Clinical implications}

In this thesis we have identified several novel pathways implicated in platelet procoagulant activity and coagulation, namely activation steps involving the P2Y 12 ADP receptor, integrin $\alpha \mathrm{llb} \beta 3$ and factor XII (Figure 4). Signaling by ADP via P2 $\mathrm{Y}_{12}$ and by fibrinogen via integrin $\alpha$ llb $\beta 3$ appears to prolong the rise in intracellular $\mathrm{Ca}^{2+}$ level in platelets, which results in PS exposure and thrombin formation on the platelet surface. Collagen, in addition to its established procoagulant effect via GPVI signaling, can also directly stimulate thrombin generation and coagulation by facilitating the activation of factor XII. This pathway is considered to be important when tissue factor is limitedly present.

Clinical inhibition of integrin $\alpha$ llb $\beta 3$ gives a high risk of adverse bleeding complications (see above). Less complete suppression of platelet activation is achieved by blocking only specific pathways leading to $\alpha$ llb $\beta 3$ activation. Inhibition of platelet $\mathrm{P}_{2} \mathrm{Y}_{12}$ receptors provides a way to do so. Similarly to integrin inhibition, blocking of $\mathrm{P} 2 \mathrm{Y}_{12}$ suppresses both platelet aggregation and platelet procoagulant activity. This sheds a new light on the action mechanism of existing medication directed against this receptor. Currently used in the clinic is clopidogrel, a thienopyridine that after metabolic activation 


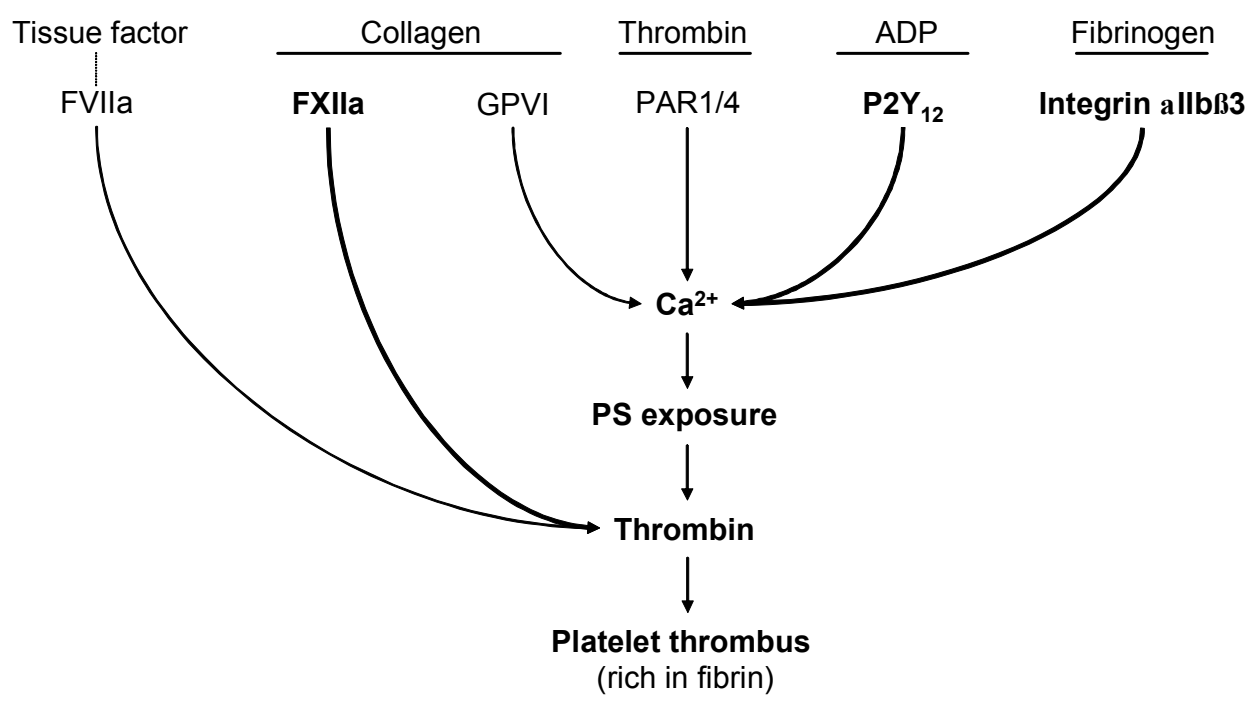

Figure 4. Novel pathways identified that promote platelet procoagulant activity and coagulation. It is already known that thrombin and collagen stimulate the procoagulant response of platelets which then promotes again the generation of thrombin on the platelet surface. Tissue factor is thereby an important initiator of the coagulation pathway. Now an additional role of collagen was identified in that it activates factor XII which triggers the intrinsic pathway of coagulation. Furthermore, $\mathrm{P}_{2} \mathrm{Y}_{12}$ signaling and integrin $\alpha \mathrm{llb} \beta 3$ outside-in signaling in platelets were found to play an important role in platelet procoagulant activity. Feed-forward loops are not indicated. These newly identified components could be interesting targets for future antithrombotic therapy.

irreversibly antagonizes platelet $\mathrm{P}_{2} \mathrm{Y}_{12}$ receptors. Although clopidogrel treatment causes significant benefit in patients suffering from cardiovascular diseases, there appears to be a striking response variability among patients. ${ }^{66,67}$ Various mechanisms responsible for clopidogrel non-responsiveness, inappropriately called 'resistance', have been identified: i.e. inadequate (hepatic) production of the active metabolite, polymorphisms of the platelet receptor, and increased turnover of platelets. Intervention with clopidogrel resulted in a low bleeding risk, probably because of incomplete inhibition of $\mathrm{P}_{2} \mathrm{Y}_{12}$ receptors in many of the patients. ${ }^{67}$ This differs from the situation in patients completely lacking the $\mathrm{P}_{2} \mathrm{Y}_{12}$ receptors, who have slightly prolonged bleeding times. In Chapter 3 it is shown that the thrombogram method of measuring thrombin generation is suitable for assessing the variability of responsiveness of patients to clopidogrel, even though only a limited number of subjects was included in this study.

Current attention regarding $\mathrm{P}_{2} \mathrm{Y}_{12}$ inhibitors focuses on the thienopyridine prodrug prasugrel, which results in a more potent antiaggregatory effect than clopidogrel, with rapid onset and long duration. ${ }^{68}$ The active metabolite of prasugrel has also been demonstrated to inhibit platelet procoagulant activity via $\mathrm{P} 2 \mathrm{Y}_{12 .}{ }^{69}$ In addition to prasugrel, the direct reversible $\mathrm{P}_{2} \mathrm{Y}_{12}$ antagonists AZD6140 and cangrelor (AR-C69931MX) are currently in phase 3 clinical trials. Similarly to prasugrel, these antagonists show a more rapid onset of action and greater degree of platelet inhibition than clopidogrel, but with so far no significant increase in bleeding. ${ }^{66,70,71}$ 
An attractive new target for antithrombotic therapy is $\mathrm{PI}-\mathrm{K} \beta$, as this signaling protein plays a role not only in $\mathrm{P}_{2} \mathrm{Y}_{12-}$ and, likely, integrin-dependent procoagulant activity but also in the glycoprotein VI-dependent procoagulant response. ${ }^{72}$ Inhibition of this $\mathrm{PI} 3-\mathrm{K}$ isoform may be a novel effective approach, especially because this enzyme functions to enhance (rather than to allow) a number of platelet responses, including platelet procoagulant activity and aggregation.

With respect to the coagulation system, antagonists of factor XII may be beneficial in reducing thrombus and clot formation without affecting the coagulation system as a whole. Experiments with mice indicated that factor XII deficiency results in instable thrombi that tend to embolize. Future studies designed to monitor effects of embolization throughout the body will be necessary to gain further insight into the safety and efficacy of factor XII as an antithrombotic target. Hopefully the research described in this thesis will provide handles for the search for new antithrombotic targets with higher efficacy and safety for patients. 


\section{References}

1. Bevers EM, Comfurius P, van Rijn JLML, Hemker HC, Zwaal RFA. Generation of prothrombin-converting activity and the exposure of phosphatidylserine at the outer surface of platelets. Eur J Biochem. 1982;122:429-436.

2. Monroe DM, Hoffman M, Roberts HR. Platelets and thrombin generation. Arterioscler Thromb Vasc Biol. 2002;22:1381-1389.

3. Heemskerk JW, Kuijpers MJ, Munnix IC, Siljander PR. Platelet collagen receptors and coagulation. A characteristic platelet response as possible target for antithrombotic treatment. Trends Cardiovasc Med. 2005;15:86-92.

4. Gachet C. P2 receptors, platelet function and pharmacological implications. Thromb Haemost. 2008;99:466-472.

5. Léon C, Ravanat C, Freund M, Cazenave JP, Gachet C. Differential involvement of the P2Y, and $\mathrm{P}_{2} \mathrm{Y}_{12}$ receptors in platelet procoagulant activity. Arterioscler Thromb Vasc Biol. 2003;23:1941-1947.

6. Storey RF, Sanderson HM, White AE, May JA, Cameron KE, Heptinstall S. The central role of the P2T receptor in amplification of human platelet activation, secretion and procoagulant activity. Br J Haematol. 2000;110:925-934.

7. Sage SO, Yamoah EH, Heemskerk JW. The roles of $P 2 X_{1}$ and $\mathrm{P}_{2} \mathrm{~T}_{\mathrm{AC}}$ receptors in ADPevoked calcium signaling in human platelets. Cell Calcium. 2000;28:119-126.

8. Van Gorp RM, Feijge MA, Vuist WM, Rook MB, Heemskerk JW. Irregular spiking in free calcium concentration in single, human platelets. Regulation by modulation of the inositol trisphosphate receptors. Eur J Biochem. 2002;269:1543-1552.

9. Keularts IM, van Gorp RM, Feijge MA, Vuist WM, Heemskerk JW. $\alpha 2 A$-adrenergic receptor stimulation potentiates calcium release in platelets by modulating cAMP levels. J Biol Chem. 2000;275:1763-1772.

10. Hardy AR, Jones ML, Mundell SJ, Poole AW. Reciprocal cross-talk between P2Y 1 and P2Y ${ }_{12}$ receptors at the level of calcium signaling in human platelets. Blood. 2004;104:1745-1752.

11. Anderson KE, Jackson SP. Class I phosphoinositide 3-kinases. Int J Biochem Cell Biol. 2003;35:1028-1033.

12. Cosemans JM, Munnix IC, Wetzker R, Heller R, Jackson SP, Heemskerk JW. Continuous signaling via PI3K isoforms $\beta$ and $\gamma$ is required for platelet ADP receptor function in dynamic thrombus stabilization. Blood. 2006;108:3045-3052.

13. Jackson SP, Schoenwaelder SM, Goncalves I, Nesbitt WS, Yap CL, Wright CE, Kenche V, Anderson KE, Dopheide SM, Yuan Y, Sturgeon SA, Prabaharan H, Thompson PE, Smith GD, Shepherd PR, Daniele N, Kulkarni S, Abbott B, Saylik D, Jones C, Lu L, Giuliano S, Hughan SC, Angus JA, Robertson AD, Salem HH. PI 3-kinase p110ß: a new target for antithrombotic therapy. Nat Med. 2005;11:507-514.

14. Lian L, Wang Y, Draznin J, Eslin D, Bennett JS, Poncz M, Wu D, Abrams CS. The relative role of PLC $\beta$ and PI3K $\gamma$ in platelet activation. Blood. 2005;106:110-117.

15. Hirsch E, Bosco O, Tropel P, Laffargue M, Calvez R, Altruda F, Wymann M, Montrucchio G. Resistance to thromboembolism in PI3K $\gamma$-deficient mice. FASEB J. 2001;15:2019-2021.

16. Kim S, Jin J, Kunapuli SP. Akt activation in platelets depends on Gi signaling pathways. J Biol Chem. 2004;279:4186-4195.

17. Kim S, Jin J, Kunapuli SP. Relative contribution of G-protein-coupled pathways to proteaseactivated receptor-mediated Akt phosphorylation in platelets. Blood. 2006;107:947-954.

18. Woulfe D, Jiang $H$, Morgans A, Monks R, Birnbaum M, Brass LF. Defects in secretion, aggregation, and thrombus formation in platelets from mice lacking Akt2. J Clin Invest. 2004;113:441-450.

19. Schlessinger J. Cell signaling by receptor tyrosine kinases. Cell. 2000;103:211-225.

20. Baldassare JJ, Henderson PA, Tarver A, Fisher GJ. Thrombin activation of human platelets dissociates a complex containing gelsolin and actin from phosphatidylinositide-specific phospholipase C $\gamma 1$. Biochem J. 1997;324 (Pt 1):283-287. 
21. Banfic H, Downes CP, Rittenhouse SE. Biphasic activation of PKB $\alpha / A k t$ in platelets. Evidence for stimulation both by phosphatidylinositol 3,4-bisphosphate, produced via a novel pathway, and by phosphatidylinositol 3,4,5-trisphosphate. J Biol Chem. 1998;273:11630-11637.

22. Chen J, De S, Damron DS, Chen WS, Hay N, Byzova TV. Impaired platelet responses to thrombin and collagen in Akt1-deficient mice. Blood. 2004;104:1703-1710.

23. Li D, August S, Woulfe DS. GSK3 $\beta$ is a negative regulator of platelet function and thrombosis. Blood. 2008;111:3522-3530.

24. Butenas S, Cawthern KM, van 't Veer C, DiLorenzo ME, Lock JB, Mann KG. Antiplatelet agents in tissue factor-induced blood coagulation. Blood. 2001;97:2314-2322.

25. Ilveskero $S$, Lassila R. Abciximab inhibits procoagulant activity but not the release reaction upon collagen- or clot-adherent platelets. J Thromb Haemost. 2003;1:805-813.

26. Pedicord DL, Thomas BE, Mousa SA, Dicker IB. Glycoprotein IIb/Illa receptor antagonists inhibit the development of platelet procoagulant activity. Thromb Res. 1998;90:247-258.

27. Reverter JC, Béguin S, Kessels H, Kumar R, Hemker HC, Coller BS. Inhibition of plateletmediated, tissue-factor-induced thrombin generation by the mouse/human chimeric 7E3 antibody. Potential implications for the effect of c7E3 Fab treatment on acute thrombosis and 'clinical restenosis'. J Clin Invest. 1996;98:863-874.

28. Byzova TV, Plow EF. Networking in the hemostatic system. Integrin $\alpha$ llb $\beta 3$ binds prothrombin and influences its activation. J Biol Chem. 1997;272:27183-27188.

29. Watson SP, Auger JM, McCarty OJ, Pearce AC. GPVI and integrin $\alpha$ llb $\beta 3$ signaling in platelets. J Thromb Haemost. 2005;3:1752-1762.

30. Shattil SJ, Newman PJ. Integrins: dynamic scaffolds for adhesion and signaling in platelets. Blood. 2004;104:1606-1615.

31. Razmara M, Hu H, Masquelier M, Li N. Glycoprotein Ilb/llla blockade inhibits platelet aminophospholipid exposure by potentiating translocase and attenuating scramblase activity. Cell Mol Life Sci. 2007;64:999-1008.

32. Moser M, Nieswandt B, Ussar S, Pozgajova M, Fassler R. Kindlin-3 is essential for integrin activation and platelet aggregation. Nat Med. 2008;14:325-330.

33. Nieswandt B, Moser M, Pleines I, Varga-Szabo D, Monkley S, Critchley D, Fassler R. Loss of talin1 in platelets abrogates integrin activation, platelet aggregation, and thrombus formation in vitro and in vivo. J Exp Med. 2007;204:3113-3118.

34. Petrich BG, Marchese P, Ruggeri ZM, Spiess S, Weichert RA, Ye F, Tiedt R, Skoda RC, Monkley SJ, Critchley DR, Ginsberg MH. Talin is required for integrin-mediated platelet function in hemostasis and thrombosis. J Exp Med. 2007;204:3103-3111.

35. Bassler N, Loeffler C, Mangin P, Yuan Y, Schwarz M, Hagemeyer CE, Eisenhardt SU, Ahrens I, Bode C, Jackson SP, Peter K. A mechanistic model for paradoxical platelet activation by ligand-mimetic $\alpha$ llb $\beta 3$ (GPIlb/llla) antagonists. Arterioscler Thromb Vasc Biol. 2007;27:e9-15.

36. Quinn MJ, Byzova TV, Qin J, Topol EJ, Plow EF. Integrin $\alpha$ llb $\beta 3$ and its antagonism. Arterioscler Thromb Vasc Biol. 2003;23:945-952.

37. Quinn MJ, Plow EF, Topol EJ. Platelet glycoprotein Ilb/llla inhibitors: recognition of a twoedged sword? Circulation. 2002;106:379-385.

38. Schwarz M, Katagiri Y, Kotani M, Bassler N, Loeffler C, Bode C, Peter K. Reversibility versus persistence of GPIlb/llla blocker-induced conformational change of GPIlb/lla ( $\alpha$ llb $\beta 3$, CD41/CD61). J Pharmacol Exp Ther. 2004;308:1002-1011.

39. Xiao T, Takagi J, Coller BS, Wang JH, Springer TA. Structural basis for allostery in integrins and binding to fibrinogen-mimetic therapeutics. Nature. 2004;432:59-67.

40. Schwarz M, Meade G, Stoll P, Ylanne J, Bassler N, Chen YC, Hagemeyer CE, Ahrens I, Moran N, Kenny D, Fitzgerald D, Bode C, Peter K. Conformation-specific blockade of the integrin GPIlb/Illa: a novel antiplatelet strategy that selectively targets activated platelets. Circ Res. 2006;99:25-33.

41. Wilner GD, Nossel HL, LeRoy EC. Activation of Hageman factor by collagen. J Clin Invest. 1968;47:2608-2615. 
42. Zacharski LR, Rosenstein R. Failure of collagen to activate factor XII. Thromb Res. 1975;7:929-933.

43. Kawamoto $\mathrm{Y}$, Kaibara M. Procoagulant activity of collagen. Effect of difference in type and structure of collagen. Biochim Biophys Acta. 1990;1035:361-368.

44. Renné T, Pozgajova M, Gruner S, Schuh K, Pauer HU, Burfeind P, Gailani D, Nieswandt B. Defective thrombus formation in mice lacking coagulation factor XII. J Exp Med. 2005;202:271-281.

45. Rosen ED, Gailani D, Castellino FJ. FXI is essential for thrombus formation following $\mathrm{FeCl}_{3}$ induced injury of the carotid artery in the mouse. Thromb Haemost. 2002;87:774-776.

46. Siljander PR, Munnix ICA, Smethurst PA, Deckmyn H, Lindhout T, Ouwehand WH, Farndale RW, Heemskerk JW. Platelet receptor interplay regulates collagen-induced thrombus formation in flowing human blood. Blood. 2004;103:1333-1341.

47. Smith SA, Mutch NJ, Baskar D, Rohloff P, Docampo R, Morrissey JH. Polyphosphate modulates blood coagulation and fibrinolysis. Proc Natl Acad Sci USA. 2006;103:903-908.

48. Gruner S, Prostredna M, Koch M, Miura Y, Schulte V, Jung SM, Moroi M, Nieswandt B. Relative antithrombotic effect of soluble GPVI dimer compared with anti-GPVI antibodies in mice. Blood. 2005;105:1492-1499.

49. Massberg S, Gawaz M, Gruner S, Schulte V, Konrad I, Zohlnhofer D, Heinzmann U, Nieswandt B. A crucial role of glycoprotein $\mathrm{VI}$ for platelet recruitment to the injured arterial wall in vivo. J Exp Med. 2003;197:41-49.

50. Nieswandt B, Brakebusch C, Bergmeier W, Schulte V, Bouvard D, Mokhtari-Nejad R, Lindhout T, Heemskerk JW, Zirngibl H, Fassler R. Glycoprotein VI but not $\alpha 2 \beta 1$ integrin is essential for platelet interaction with collagen. Embo J. 2001;20:2120-2130.

51. Dubois C, Panicot-Dubois L, Merrill-Skoloff G, Furie B, Furie BC. Glycoprotein VI-dependent and -independent pathways of thrombus formation in vivo. Blood. 2006;107:3902-3906.

52. Kuijpers MJ, Munnix IC, Cosemans JM, Van Vlijmen BJ, Reutelingsperger CP, Oude Egbrink MG, Heemskerk JW. Key role of platelet procoagulant activity in tissue factor- and collagendependent thrombus formation in arterioles and venules in vivo. Differential sensitivity to thrombin inhibition. Microcirculation. 2008 in press:DOI: 10.1080/10739680701653517.

53. Mangin P, Yap CL, Nonne C, Sturgeon SA, Goncalves I, Yuan Y, Schoenwaelder SM, Wright $\mathrm{CE}$, Lanza F, Jackson SP. Thrombin overcomes the thrombosis defect associated with platelet GPVI/FcR $\gamma$ deficiency. Blood. 2006;107:4346-4353.

54. Mackman N. Role of tissue factor in hemostasis and thrombosis. Blood Cells Mol Dis. 2006;36:104-107.

55. Panes O, Matus V, Saez CG, Quiroga T, Pereira J, Mezzano D. Human platelets synthesize and express functional tissue factor. Blood. 2007;109:5242-5250.

56. Cho J, Furie BC, Coughlin SR, Furie B. A critical role for extracellular protein disulfide isomerase during thrombus formation in mice. J Clin Invest. 2008;118:1123-1131.

57. Reinhardt C, von Bruhl ML, Manukyan D, Grahl L, Lorenz M, Altmann B, Dlugai S, Hess S, Konrad I, Orschiedt L, Mackman N, Ruddock L, Massberg S, Engelmann B. Protein disulfide isomerase acts as an injury response signal that enhances fibrin generation via tissue factor activation. J Clin Invest. 2008;118:1110-1122.

58. Maroney SA, Haberichter SL, Friese P, Collins ML, Ferrel JP, Dale GL, Mast AE. Active tissue factor pathway inhibitor is expressed on the surface of coated platelets. Blood. 2007;109:1931-1937.

59. Gailani D, Renne T. Intrinsic pathway of coagulation and arterial thrombosis. Arterioscler Thromb Vasc Biol. 2007;27:2507-2513.

60. Doggen CJ, Rosendaal FR, Meijers JC. Levels of intrinsic coagulation factors and the risk of myocardial infarction among men: opposite and synergistic effects of factors XI and XII. Blood. 2006;108:4045-4051.

61. Govers-Riemslag JW, Smid M, Cooper JA, Bauer KA, Rosenberg RD, Hack CE, Hamulyak K, Spronk HM, Miller GJ, ten Cate H. The plasma kallikrein-kinin system and risk of cardiovascular disease in men. J Thromb Haemost. 2007;5:1896-1903. 
62. Wang X, Cheng Q, Xu L, Feuerstein GZ, Hsu MY, Smith PL, Seiffert DA, Schumacher WA, Ogletree ML, Gailani D. Effects of factor IX or factor XI deficiency on ferric chloride-induced carotid artery occlusion in mice. J Thromb Haemost. 2005;3:695-702.

63. Wang X, Smith PL, Hsu MY, Gailani D, Schumacher WA, Ogletree ML, Seiffert DA. Effects of factor XI deficiency on ferric chloride-induced vena cava thrombosis in mice. J Thromb Haemost. 2006;4:1982-1988.

64. Blat $Y$, Seiffert D. A renaissance for the contact system in blood coagulation? Thromb Haemost. 2008;99:457-460.

65. Colman RW, Schmaier AH. Contact system: a vascular biology modulator with anticoagulant, profibrinolytic, antiadhesive, and proinflammatory attributes. Blood. 1997;90:3819-3843.

66. Michelson AD. P2Y 12 antagonism: promises and challenges. Arterioscler Thromb Vasc Biol. 2008;28:s33-38.

67. Gurbel PA, Tantry US. Drug insight: Clopidogrel nonresponsiveness. Nat Clin Pract Cardiovasc Med. 2006;3:387-395.

68. Niitsu Y, Jakubowski JA, Sugidachi A, Asai F. Pharmacology of CS-747 (prasugrel, LY640315), a novel, potent antiplatelet agent with in vivo $P 2 Y_{12}$ receptor antagonist activity. Semin Thromb Hemost. 2005;31:184-194.

69. Frelinger AL, Jakubowski JA, Li Y, Barnard MR, Linden MD, Tarnow I, Fox ML, Sugidachi A, Winters KJ, Furman MI, Michelson AD. The active metabolite of prasugrel inhibits adenosine diphosphate- and collagen-stimulated platelet procoagulant activities. J Thromb Haemost. 2008;6:359-365.

70. Van Giezen JJ, Humphries RG. Preclinical and clinical studies with selective reversible direct P2Y 12 antagonists. Semin Thromb Hemost. 2005;31:195-204.

71. Husted S, Emanuelsson H, Heptinstall S, Sandset PM, Wickens M, Peters G. Pharmacodynamics, pharmacokinetics, and safety of the oral reversible P2Y 12 antagonist AZD6140 with aspirin in patients with atherosclerosis: a double-blind comparison to clopidogrel with aspirin. Eur Heart J. 2006;27:1038-1047.

72. Munnix IC. Platelet signaling to procoagulant activity and heterogeneity in thrombus formation. An in vivo and ex vivo approach. PhD Thesis, Maastricht University, Maastricht, The Netherlands, ISBN 978-90-5278-630-8. 2007. 
Summary 


\section{Interaction mechanisms of platelets and coagulation}

Hemostasis is a process which functions to arrest bleeding after vascular damage by inducing the formation of a clot. When the hemostatic balance is disturbed in intact vessels, thrombosis may occur with vascular occlusion as a result. Platelets play an important role in hemostasis as well as thrombosis. The classical concept of thrombus formation starts from the premise that after vascular injury, platelets adhere to components of the vessel wall, such as collagen, that become exposed to the blood after endothelial damage. Platelets also bind to each other and form a platelet plug or platelet aggregate. Subsequent activation of the coagulation cascade by tissue factor results in the formation of thrombin and fibrin, the latter stabilizing the platelet aggregate (thrombus). However, recently it was demonstrated that platelet activation and coagulation are interdependent processes and occur nearly simultaneously. Activated platelets can stimulate the coagulation cascade by exposing phosphatidylserine (PS) on their surface, on which coagulation factors can assemble and become activated. This greatly accelerates the formation of thrombin. The procoagulant response of platelets especially occurs upon activation with a combination of thrombin and collagen, and is due to a prolonged elevation in the intracellular calcium level of the platelets. Considering the extensive interplay of platelet activation and coagulation, it is likely that also other interaction mechanisms are involved in these two processes. The studies in this thesis confirm this notion.

In chapter 1 the main physiological activators of platelets are described, as well as the receptors and signaling pathways that are relevant for this thesis. Thrombin has an important function in coagulation, but is also a potent activator of platelets. It binds to the Gq-coupled receptors PAR1 and PAR4, resulting in the activation of the enzyme phospholipase $C \beta$. This leads to calcium mobilization from the internal stores and a subsequent rise in the intracellular calcium level. Activated platelets secrete positive mediators, like adenosine-diphosphate (ADP), which in turn will activate other platelets. Secreted ADP binds to the Gq-coupled receptor $\mathrm{P}_{2} \mathrm{Y}_{1}$ and to the Gi-coupled receptor $P 2 Y_{12}$. The $P 2 Y_{12}$ receptor inactivates the enzyme adenylate cyclase and activates phosphoinositide 3-kinase (PI3-K). In this chapter it is also described that collagen activates platelets via glycoprotein (GP) VI. This collagen receptor activates for instance phospholipase $\mathrm{C} \gamma 2$, with again a rise in the intracellular calcium level as a consequence. The fibrinogen receptor integrin $\alpha \mathrm{llb} \beta 3$ is also able to induce signaling upon interaction with the ligand. This so-called 'outside-in' signaling leads to activation of phospholipase C $\gamma 2$ as well.

Platelets play an important role in arterial thrombosis, while venous thrombosis is associated with high coagulation activity. Since platelet activation and coagulation are cooperative processes, in chapter 2 the contribution of platelets to the development of venous thrombosis is discussed. How platelets affect the thrombin generation and coagulation process is investigated in the next chapters.

In chapter 3 it is described that ADP is involved in the procoagulant response of platelets. The results show that ADP promotes the generation of thrombin in coagulating platelet-rich plasma. The ADP produced and secreted by platelets, appeared to be 
responsible for a considerable part of the thrombin-induced PS exposure. By using specific inhibitors of the ADP receptors, it is demonstrated that the procoagulant effect of ADP relies on $\mathrm{P}_{2} \mathrm{Y}_{12}$ receptor function. Signaling via this receptor causes an elevation in the intracellular calcium level which results in PS exposure and subsequent formation of thrombin. The effect of treatment with clopidogrel, directed against the P2Y 12 receptor, was assessed in patients with an increased thrombotic risk. Platelet activation processes were determined as well as the capability of activated platelets to stimulate thrombin generation by using the thrombogram method. It is shown that clopidogrel incompletely suppresses the contribution of $\mathrm{P}_{2} \mathrm{Y}_{12}$ to the platelet procoagulant response.

As it appeared that activation of the $\mathrm{P}_{2} \mathrm{Y}_{12}$ receptors enhances the procoagulant activity of platelets, the underlying signaling mechanism is investigated in chapter 4 . It is demonstrated that $A D P$, via the $\mathrm{P}_{2} \mathrm{Y}_{12}$ receptors, synergizes with thrombin to mobilize calcium from the internal stores. This synergistic effect of the $P_{2} Y_{12}$ receptors is mediated via two distinct signaling pathways. On the one hand, $\mathrm{P} 2 \mathrm{Y}_{12}$ inhibits adenylyl cyclase, which prevents the formation of cyclic AMP and the activation of protein kinase $A$. This is in accordance to the literature, where protein kinase $A$ is described to inhibit the function of the inositol 1,4,5 triphosphate receptors that are responsible for calcium mobilization. On the other hand, it was found that the $\mathrm{P}_{2} \mathrm{Y}_{12}$ receptors activate $\mathrm{PI}-\mathrm{K}$ that leads to the recruitment of phospholipase $\mathrm{C}$ isoforms. Phospholipase $\mathrm{C}$ then triggers a calcium response via the formation of inositol 1,4,5-triphosphate. By using either mice deficient in the PI3-K $\gamma$ isoform or a specific inhibitor of the PI3-K $\beta$ isoform, it is shown that only the $\beta$-isoform is involved in the elevated calcium response. Together these results indicate that the $\mathrm{P}_{2} \mathrm{Y}_{12}$ receptors enhance the platelet stimulating effect of thrombin by an increased and prolonged elevation of the calcium response, thereby facilitating the coagulation process.

Stimulation of platelets leads to activation of integrin $\alpha$ llb $\beta 3$ which enables platelets to aggregate. As integrin $\alpha \mathrm{llb} \beta 3$ antagonists not only inhibit platelet aggregation but also thrombin generation and procoagulant activity, in chapter 5 the signaling mechanism by which $\alpha$ llb $\beta 3$ is able to contribute to the coagulation process is investigated. Binding of fibrinogen to activated platelets appeared to stimulate the late phase of the calcium response, resulting in enhanced PS exposure and thrombin generation. Experiments with inhibitors indicate that this response is due to activation of $\mathrm{PI}-\mathrm{K}$, which in part relies on ADP secretion and $\mathrm{P}_{2} \mathrm{Y}_{12}$ receptor function. It is known that Src kinases and PI3-K, both activated downstream of integrin $\alpha \operatorname{llb} \beta 3$, recruit and activate phospholipase $\mathrm{C}$ isoforms. Therefore, it is likely that this enzyme is involved in the calcium signaling pathway evoked by integrin $\alpha \operatorname{llb} \beta 3$.

In chapter $\mathbf{6}$ it is hypothesized that collagen has an additional function in coagulation beyond activating platelets via GPVI. Under conditions where tissue factor is limitedly present, type I collagen appeared to stimulate the coagulation process, independent of platelets, by activating factor XII. It is demonstrated that collagen is able to bind and activate factor XII. Furthermore, collagen stimulates the formation of thrombin in plateletrich plasma via the combined activation of factor XII and GPVI on platelets. Thrombus formation and procoagulant activity were measured in studies where coagulating blood 
was perfused over a collagen surface under physiological shear conditions. Here collagen promoted the formation of large thrombi rich in fibrin and PS-exposing platelets. Thrombus formation and procoagulant activity were greatly reduced with blood deficient in factor XII or FXI. The formation of procoagulant thrombi was also dependent on glycoprotein VI signaling, as this response was greatly diminished with platelets deficient in the signaling proteins LAT or phospholipase $\mathrm{C} \gamma 2$. These findings demonstrate that collagen plays a dual role in thrombus formation under coagulant conditions. Firstly, collagen activates platelets via the GPVI-LAT-phospholipase C $\gamma 2$ signaling pathway which results in platelet aggregation and PS exposure. Secondly, collagen binds and activates factor XII and thereby initiates the coagulation cascade. The latter is especially important when tissue factor is limitedly available.

In chapter $\mathbf{7}$ the findings presented in this thesis are discussed in the light of relevant literature and their possible clinical significance is proposed. In addition to thrombin and collagen, $A D P$, via the $P 2 Y_{12}$ receptor, and fibrinogen, via integrin $\alpha \operatorname{llb} \beta 3$, contribute to the formation of procoagulant platelets by which the generation of thrombin in plasma is promoted. Collagen can also directly stimulate coagulation by facilitating the activation of factor XII. All together, the studies in this thesis may add to the current knowledge on the interaction mechanisms of platelets and coagulation and possibly provide handles for the development of new strategies for the treatment of cardiovascular diseases. 
Samenvatting 


\section{Interactiemechanismen tussen bloedplaatjes en stolling}

Onder normale condities wordt het bloed in de circulatie vloeibaar en stromend gehouden. Bij vaatwandbeschadiging zorgt een proces, genaamd hemostase, ervoor dat het bloedverlies stopt door middel van activering van het stollingssysteem. Bij verhoogde hemostase activiteit in een intact bloedvat krijgt de stolling de overhand, hetgeen kan leiden tot verstopping van het bloedvat oftewel trombose. Gebleken is dat bloedplaatjes een belangrijke rol spelen bij zowel hemostase als trombose. Het klassieke concept van trombusvorming gaat er vanuit dat bij vaatwandbeschadiging de plaatjes eerst gaan hechten aan componenten die vrijkomen bij het verdwijnen van de endotheellaag in de vaatwand, zoals collageen. Plaatjes hechten ook aan elkaar en vormen daarmee een plaatjesprop of plaatjesaggregaat. $\mathrm{Bij}$ vasculaire beschadiging zal vervolgens weefselfactor vrijkomen, dat de stolling activeert waardoor uiteindelijk trombine en fibrine gevormd worden. Het fibrinenetwerk zorgt voor stabilisatie van het plaatjesaggregaat (trombus). Sinds kort zijn er echter aanwijzingen dat de activering van plaatjes en de stolling vrijwel gelijktijdig optreden en daarmee nauw met elkaar verbonden zijn. Geactiveerde plaatjes kunnen zelf ook de stolling stimuleren door het fosfolipide fosfatidylserine (PS) op hun membraan te exposeren. Aan dit geëxposeerde PS binden stollingsfactoren die vervolgens een interactie met elkaar aangaan, waardoor de vorming van trombine aanzienlijk versneld wordt. Deze stollingsbevorderende (procoagulante) respons treedt onder meer op wanneer plaatjes geactiveerd worden door de combinatie van trombine en collageen, en deze is het gevolg van een langdurige stijging van het intracellulair calciumniveau in de cellen. Gezien de sterke mate van verwevenheid van plaatjesactivering en stolling veronderstelden we dat er ook nog andere interactiemechanismen tussen deze twee processen moeten zijn. De studies in dit proefschrift geven aan dat dit inderdaad het geval is.

In hoofdstuk 1 wordt kort ingegaan op de belangrijkste fysiologische activatoren van plaatjes en op de receptoren en signaleringsroutes die relevant zijn voor dit proefschrift. Trombine speelt een belangrijke rol in de stolling, maar is daarnaast ook een sterke activator van plaatjes. Het bindt aan de Gq-gekoppelde receptoren PAR1 en PAR4 wat resulteert in de activatie van het enzym fosfolipase $C \beta$. Dit leidt tot mobilisatie van calcium vanuit de interne opslagplaatsen, waardoor het intracellulaire calciumniveau stijgt. Geactiveerde plaatjes scheiden stoffen uit, waaronder adenosine-difosfaat (ADP), die zelf weer activerend werken op andere plaatjes. Eenmaal vrijgekomen bindt ADP aan de Gq-gekoppelde receptor P2Y $\mathrm{Y}_{1}$, alsook aan de Gi-gekoppelde receptor P2Y $\mathrm{Y}_{12}$. De $\mathrm{P}_{2} \mathrm{Y}_{12}$ receptor inactiveert het enzym adenylaatcyclase en activeert tegelijkertijd het fosfoinositide 3-kinase (PI3-K). In dit hoofdstuk is ook beschreven dat collageen de plaatjes activeert door middel van glycoproteïne (GP) VI. Deze collageenreceptor leidt tot de activering van onder meer het enzym fosfolipase $C \gamma 2$, met als gevolg weer een stijging van het intracellulair calciumniveau. De fibrinogeenreceptor integrine $\alpha$ llb $\beta 3$ kan ook signaleren na interactie met ligand. Deze zogenaamde 'outside-in' (buiten-binnen) signalering leidt eveneens tot een bepaalde mate van activering van fosfolipase $C \gamma 2$.

Plaatjes spelen een grote rol in arteriële trombose, terwijl het stollingssysteem veeleer de overhand heeft in veneuze trombose. Uitgaande van recente bevindingen dat 
de activering van plaatjes en van stolling gelijktijdig optreden, is in hoofdstuk 2 bediscussieerd dat plaatjes ook een rol moeten hebben bij het ontstaan van veneuze trombose. In hoofdstukken daarna zijn een aantal mechanismen bestudeerd, waardoor plaatjes de stolling kunnen beïnvloeden.

Hoofdstuk 3 beschrijft dat ook ADP een rol heeft in de procoagulante respons van plaatjes. De resultaten tonen aan dat ADP de vorming van trombine stimuleert in stollend plaatjes-rijk plasma. Het ADP dat door plaatjes geproduceerd werd, bleek verantwoordelijk voor een aanzienlijk deel van de PS-expositie van plaatjes, die met trombine gestimuleerd waren. Met behulp van specifieke remmers van de twee ADPreceptoren kon aangetoond worden dat het procoagulante effect van ADP verloopt via de $\mathrm{P}_{2} \mathrm{Y}_{12}$ receptor. Signalering via deze receptor leidt tot een verhoogde stijging van het intracellulair calciumniveau, als gevolg waarvan PS-expositie kan plaatsvinden en er meer trombine gegenereerd wordt. In patiënten met een verhoogd tromboserisico is bestudeerd wat de gevolgen waren van medicatie met clopidogrel, gericht tegen de $\mathrm{P}_{2} \mathrm{Y}_{12}$ receptoren. Hier werd onder meer gebruik gemaakt van de trombogram-methode waarbij trombinegeneratie gemeten wordt. De resultaten tonen aan dat bij veel patiënten clopidogrel inname leidt tot een incomplete onderdrukking van de bijdrage van $\mathrm{P}_{2} \mathrm{Y}_{12}$ aan de procoagulante plaatjesrespons.

Aangezien activering van de $\mathrm{P}_{2} \mathrm{Y}_{12}$ receptoren een duidelijk stimulerend effect bleek te hebben op het stollingsbevorderend vermogen van plaatjes, is in hoofdstuk $\mathbf{4}$ het signaleringsmechanisme hiervan in plaatjes onderzocht. Aangetoond is dat trombine en $A D P$, via $P 2 Y_{12}$ receptoren, synergistisch werken bij het vrijzetten van calcium uit de interne opslagplaatsen. Verder bleek de bijdrage van de $\mathrm{P}_{2} \mathrm{Y}_{12}$ receptoren te verlopen via twee afzonderlijke maar complementaire signaleringswegen. Enerzijds remt $\mathrm{P}_{2} \mathrm{Y}_{12}$ het adenylaatcyclase, waardoor geen cyclisch AMP gevormd wordt en het proteïnekinase A inactief blijft. Dit komt goed overeen met de literatuur, waarin beschreven is dat proteïnekinase $A$ de werking vermindert van inositol 1,4,5-trifosfaatreceptoren, die zorgen voor calcium mobilisatie. Anderzijds vonden wij dat de $\mathrm{P}_{2} \mathrm{Y}_{12}$ receptoren PI3-K activeren, hetgeen zorgt voor de rekrutering van fosfolipase $\mathrm{C}$ isovormen. Fosfolipase C produceert inositol 1,4,5-trifosfaat met uiteraard een calciumrespons als gevolg. Door gebruik te maken van muizen die deficiënt waren in de isovorm $\mathrm{PI} 3-\mathrm{K} \gamma$ en van een remmer van de isovorm $\mathrm{PI}-\mathrm{K} \beta$ kon aangetoond worden dat alleen de $\beta$ isovorm een rol speelt bij de verhoogde calciumrespons. Samengevat laten deze resultaten zien dat de $\mathrm{P} 2 \mathrm{Y}_{12}$ receptoren het stimulerende effect van trombine op plaatjes versterken door te zorgen voor een verhoogde dan wel verlengde stijging van het calciumniveau, waardoor ook de procoagulante respons bevorderd wordt.

Algemeen bekend is dat stimulering van plaatjes leidt tot activering van integrine $\alpha$ llb $\beta 3$, waardoor plaatjes kunnen aggregeren. Omdat blokkering van dit integrine niet alleen de aggregaatvorming maar ook de procoagulante plaatjesrespons bleek te onderdrukken, is in hoofdstuk $\mathbf{5}$ onderzocht via welk signaleringsmechanisme $\alpha \mathrm{llb} \beta 3$ hieraan kan bijdragen. De resultaten tonen aan dat de binding van fibrinogeen aan geactiveerde plaatjes leidt tot een stimulering van vooral de latere fase van de calciumrespons, met als gevolg een uiteindelijk verhoogde PS-expositie en 
trombinevorming. Experimenten met remmers gaven aan dat hieraan signalering via PI3$K$ ten grondslag ligt, die ten dele via ADP en de $P 2 Y_{12}$ receptor verloopt. Src kinases en $\mathrm{PI} 3-\mathrm{K}$, beiden geactiveerd door integrine $\alpha \mathrm{llb} \beta 3$, zorgen voor de rekrutering en activering van fosfolipase $C$ isovormen. Het is daarom aannemelijk dat fosfolipase $C$ een rol speelt bij de calciumsignaleringsroute opgewekt door integrine allb $\beta 3$.

In hoofdstuk 6 is uitgegaan van de veronderstelling dat collageen de stolling niet alleen beïnvloedt door activering van plaatjes via GPVI. Onder condities waarbij weefselfactor beperkt aanwezig is, bleek type I collageen de stolling, onafhankelijk van bloedplaatjes, te stimuleren door activatie van factor XII. Aangetoond is dat collageen ook in staat is om aan factor XII te binden en deze factor vervolgens te activeren. Daarnaast is gevonden dat collageen in plaatjes-rijk plasma de trombinevorming stimuleert zowel via activering van factor XII als via verhoogde PS-expositie op plaatjes, middels GPVI. Door perfusieproeven, waarbij stollend bloed over een collageenoppervlak stroomt, is het mogelijk om het trombus-vormende proces en de procoagulante activiteit van de plaatjes te bestuderen onder relevante stromingscondities. Daarbij bleek dat collageen zorgde voor de vorming van grote trombi met veel fibrine en procoagulante plaatjes. Bloed van muizen die deficiënt in factor XII of $\mathrm{XI}$ waren zorgde voor een duidelijk verminderde trombusvorming en procoagulante activiteit. De vorming van procoagulante trombi was bovendien afhankelijk van de mate van GPVI signalering, aangezien plaatjes deficiënt in de signaleringseiwitten LAT en fosfolipase $\mathrm{C} \gamma 2$ veel kleinere trombi vormden. Op basis van deze resultaten is geconcludeerd dat collageen een dubbele functie heeft in de trombusvorming onder stollingscondities: collageen activeert plaatjes via de GPVI-LAT-fosfolipase C $\gamma 2$ signaleringsweg, die leidt tot plaatjesaggregatie en PS-expositie; daarnaast bindt en activeert collageen factor XII waardoor het stollingssysteem in werking treedt. Dit laatste is met name van belang wanneer weefselfactor slechts beperkt aanwezig is.

In hoofdstuk 7 zijn de bevindingen van dit proefschrift bediscussieerd op basis van de literatuur en is ingegaan op de mogelijke klinische relevantie. Naast trombine en collageen zorgen ook ADP, via de $\mathrm{P}_{2} \mathrm{Y}_{12}$ receptor, en fibrinogeen, via integrine $\alpha$ llb $\beta 3$, voor de vorming van procoagulante plaatjes, als gevolg waarvan de trombinevorming in plasma gestimuleerd wordt. Collageen kan bovendien de stolling direct stimuleren door activering van factor XII. De studies in dit proefschrift beogen daarmee bij te dragen tot een beter begrip van de interactiemechanismen tussen plaatjesactivering en stolling, hetgeen wellicht kan leiden tot nieuwe medicatie voor de behandeling van cardiovasculaire aandoeningen. 
Curriculum vitae 


\section{Curriculum vitae}

Paola Elisabeth Johannes van der Meijden was born on February $15^{\text {th }} 1981$ in Geleen, The Netherlands. She completed secondary school (VWO) at the Albert Schweitzer Scholengemeenschap in Geleen in 1999, after which she started to study Biological Health Sciences at the University of Maastricht. At the Department of Biochemistry, University of Maastricht, she followed her graduation internship under supervision of Dr. J.W.M. Heemskerk. On August $31^{\text {th }} 2003$ she received her Master's degree in Biological Health Sciences. On September $1^{\text {st }} 2003$ she started as a research assistant at the Cardiovascular Research Institute Maastricht (CARIM) at the Department of Biochemistry directed by Prof. Dr. J. Rosing. Then she continued working there as a PhD student under supervision of Dr. J.W.M. Heemskerk. The results of the research she performed are described in this thesis. After taking several courses in the field of cardiovascular research, she received the CARIM PhD-Training Certificate in 2006. For her research she visited several times the laboratory of Prof. Dr. S. Watson in the Centre for Cardiovascular Sciences Institute of Biomedical Research (Birmingham, UK). She also visited the laboratory of Prof. Dr. R. Wetzker and Dr. R. Heller in the Institute of Molecular Cell Biology (Jena, Germany) and the laboratory of Dr. T. Renné in Institute of Clinical Biochemistry and Pathobiochemistry (Würzburg, Germany). During her PhDperiod she presented the research data at conferences in Erfurt, Würzburg, Reading, Sydney and Geneva and received young investigator and travel awards. She was also selected as PhD student of August 2008. Presently, she is working as a researcher at the Department of Biochemistry at the University of Maastricht. 


\section{Curriculum vitae}

Paola Elisabeth Johannes van der Meijden werd geboren op 15 februari 1981 in Geleen. Zij behaalde in 1999 haar VWO diploma aan de Albert Schweitzer Scholengemeenschap te Geleen, waarna zij begon met de studie Gezondheidswetenschappen aan de Universiteit Maastricht. Bij de vakgroep Biochemie aan de Universiteit Maastricht deed zij haar afstudeerstage onder begeleiding van Dr. J.W.M. Heemskerk. Op 31 augustus 2003 mocht zij haar doctoraal diploma Gezondheidswetenschappen met als afstudeerrichting Biologische Gezondheidkunde in ontvangst nemen. Per 1 september 2003 startte zij als onderzoeksmedewerkster binnen het Cardiovascular Research Institute Maastricht (CARIM) bij de vakgroep Biochemie van Prof. Dr. J. Rosing. Hier werd zij vervolgens Assistent in Opleiding (AIO) en werkte onder directe begeleiding van Dr. J.W.M. Heemskerk. De resultaten van het promotieonderzoek staan beschreven in dit proefschrift. Na het volgen van een cursusprogramma op het gebied van hart- en vaatziekten ontving zij in 2006 het CARIM PhD-Training Certificate. Voor haar onderzoek bezocht zij verscheidene malen het laboratorium van Prof. Dr. S. Watson in het Centre for Cardiovascular Sciences Institute of Biomedical Research (Birmingham, Verenigd Koninkrijk). Tevens bezocht zij de laboratoria van Prof. Dr. R. Wetzker en Dr. R. Heller in het Institute of Molecular Cell Biology (Jena, Duitsland) en van Dr. T. Renné in het Institute of Clinical Biochemistry and Pathobiochemistry (Würzburg, Duitsland). Tijdens haar AIO-periode presenteerde zij de onderzoeksresultaten op congressen in onder andere Erfurt, Würzburg, Reading, Sydney en Genève en kreeg daarvoor young investigator en travel awards. Bovendien werd zij verkozen tot Promovendus van de Maand. Momenteel is zij werkzaam als onderzoeker bij de vakgroep Biochemie aan de Universiteit Maastricht. 

Publications 


\section{List of publications}

\section{Papers}

- Van der Meijden PEJ, Feijge MAH, Giesen PLA, Huijberts M, Van Raak LPM and Heemskerk JWM. Platelet $P 2 Y_{12}$ receptors enhance signaling towards procoagulant activity and thrombin generation. A study with healthy subjects and patients at thrombotic risk. Thromb Haemost. 2005; 93: 1128-1136.

- Van der Meijden PEJ, Heemskerk JWM, Hamulyák K and Ten Cate H. Classification of venous thromboembolism (VTE). Platelets in venous thrombosis. J Thromb Haemost. 2005; 3: 2575-2577.

- Munnix ICA, Strehl A, Kuijpers MJE, Auger JM, Van der Meijden PEJ, Van Zandvoort MAM, Oude Egbrink MGA, Nieswandt B and Heemskerk JWM. The glycoprotein $\mathrm{VI}$ - phospholipase $\mathrm{C} \gamma 2$ signaling pathway controls collagen- and tissue factor-induced thrombus formation in vitro and in vivo. Arterioscler Thromb Vasc Biol. 2005; 25: 2673-2678.

- Strehl A, Munnix ICA, Kuijpers MJE, Van der Meijden PEJ, Cosemans JMEM, Feijge MAH, Nieswandt B and Heemskerk JWM. Dual role of platelet protein kinase $\mathrm{C}$ in thrombus formation: Stimulation of proaggregatory and suppression of procoagulant activity in platelets. J Biol Chem. 2007; 282: 7046-7055.

- Van der Meijden PEJ, Schoenwaelder SM, Feijge MAH, Cosemans JMEM, Munnix ICA, Wetzker R, Heller R, Jackson SP and Heemskerk JWM. Dual P2Y 12 receptor signaling in thrombin-stimulated platelets. Involvement of phosphoinositide 3-kinase $\beta$ but not $\gamma$ isoform in $\mathrm{Ca}^{2+}$ mobilization and procogulant activity. FEBS J. 2008; 275: 371-385.

- Vanschoonbeek K, Wouters K, Van der Meijden PEJ, Van Gorp PJ, Schurgers LJ, Hofker MH, De Maat MP and Heemskerk JWM. Anticoagulant effect of dietary fish oil in hyperlipidemia: an mRNA expression study in APOE2 knock-in mice. Arterioscler Thromb Vasc Biol. 2008; in press: DOI 10.1161/ATVBAHA.107.156992.

- Schols SEM, Van der Meijden PEJ, Van Oerle R, Curvers J, Heemskerk JWM and Van Pampus ECM. Increased thrombin generation and fibrinogen level after therapeutic plasma transfusion: Relation to bleeding. Thromb Haemost. 2008; 99: 6470.

- Van der Meijden PEJ, Munnix ICA, Auger JM, Govers-Riemslag JW, Cosemans JMEM, Kuijpers MJE, Spronk HM, Watson SP, Renné $T$ and Heemskerk JWM. Dual role of collagen in factor XII-dependent thrombus and clot formation. Blood. 2008; invited resubmission.

- Van der Meijden PEJ. Interactiemechanismen tussen bloedplaatjes en bloedstolling. Nieuwsbrief Vasculaire Geneeskunde. 2008; 4: 25-27. 
- Van der Meijden PEJ, Feijge MAH, Gilio K, Cauwenberghs S, Hamulyák K and Heemskerk JWM. Role of integrin $\alpha$ llb $\beta 3$ outside-in signaling in the development of platelet procoagulant activity and thrombin generation. 2008; submitted.

- Munnix ICA, Cosemans JMEM, Feijge MAH, Van der Meijden PEJ, van Montfoort APA, Farndale RW, Koyasu S, Heller R, Sage SO, Jackson SP and Heemskerk JWM. Specific roles PI3K isoforms and in glycoprotein VI-induced platelet signaling to procoagulant activity. 2008; submitted.

- Cosemans JMEM, Van der Meijden PEJ, Feijge MAH, Cleutjens JPM, Poole AW, Johnson JL and Heemskerk JWM. Effects of plasma- and platelet-derived matrix metalloproteinases on collagen-dependent thrombus formation. 2008; submitted. 


\section{Abstracts}

- Van der Meijden PEJ, Beks WMHJ, Feijge MAH, Giesen PLA, Huijberts M, Van Raak EPM and Heemskerk JWM. Role of ADP receptors on platelet-dependent thrombin generation in whole plasma from healthy subjects and patients at thrombotic risk. Platelets. 2004; 15: 515.

- Van der Meijden PEJ, Beks WMHJ, Feijge MAH, Giesen PLA, Huijberts M, Van Raak EPM and Heemskerk JWM. Role of ADP receptors on platelet-dependent thrombin generation in whole plasma from healthy subjects and patients at thrombotic risk. Platelets. 2005; 16: 246.

- Van der Meijden PEJ, Feijge MAH, Van Raak EPM and Heemskerk JWM. P2Y 12 receptor stimulation prolongs thrombin-induced calcium responses and procoagulant activity via novel signaling pathway; variable effect of clopidogrel treatment. J Thromb Haemost. 2005; 3: supplement 1.

- Munnix ICA, Kuijpers MJE, Thomassen MCLGD, Van der Meijden PEJ, oude Egbrink MGA, Van Zandvoort MAMJ, Rosing J, Siljander PRM and Heemskerk JWM. Disclosure of microdomain structure and function in arterial thrombi of heterogeneous composition. J Thromb Haemost. 2005; 3: supplement 1.

- Cosemans JMEM, Van der Meijden PEJ, Kuijpers MJE, Wetzker R, Heller R, Jackson SP, Munnix ICA and Heemskerk JWM. Differential contribution of phosphoinositide 3-kinases to platelet responses. Proc. of 21st European Platelet Meeting, Wittenberg, Germany 2006.

- Van der Meijden PEJ, Munnix ICA, Kuijpers MJE, Auger JM, Watson SP and Heemskerk JWM. Contribution of glycoprotein VI signalling to the intrinsic pathway of coagulation. Platelets. 2007; 18: 317.

- Cosemans JMEM, Van der Meijden PEJ, Wetzker R, Heller R, Jackson SP, Heemskerk JWM and Munnix ICA. Role of PI3K isoforms in platelet aggregate formation and platelet procoagulant activity. Platelets. 2007; 18: 294.

- Van der Meijden PEJ, Munnix ICA, Kuijpers MJE, Auger JM, Watson SP and Heemskerk JWM. Contributions of collagen and glycoprotein VI signalling in the intrinsic pathway of coagulation. J Thromb Haemost. 2007; 5: supplement 2.

- Cosemans JMEM, Van der Meijden PEJ, Cleutjens JPM, Heeneman S and Heemskerk JWM. Dual effect of platelet derived matrix metalloproteinases on occlusive thrombus growth. J Thromb Haemost. 2007; 5: supplement 2.

- Schols SEM, Van der Meijden PEJ, Curvers J, Heemskerk JWM and Van Pampus ECM. Detection of anti-haemostatic effect of plasma dilution via thrombin generation. J Thromb Haemost. 2007; 5: supplement 2. 
- Munnix ICA, Cosemans JMEM, Van der Meijden PEJ, Van Montfoort APA, Feijge MAH, Farndale RW, Koyasu S, Heller R, Sage SO, Jackson SP and Heemskerk JWM. Specific roles of phosphoinositide 3-kinase isoforms $\alpha$ and $\beta$ in glycoprotein VI-induced signaling to procoagulant activity. J Thromb Haemost. 2007; 5: supplement 2.

- Kuijpers MJE, Cosemans JMEM, Van der Meijden PEJ, Feijge MAH and Heemskerk JWM. Inhibition of $\mathrm{P}_{2} \mathrm{Y}_{12}$ by AZD6140 reduces thrombus formation and procoagulant activity on collagen and atherosclerotic plaques. J Thromb Haemost. 2007; 5: supplement 2.

- Van der Meijden PEJ, Munnix ICA, Kuijpers MJE, Auger JM, Watson SP and Heemskerk JWM. Synergistic activation of the factor XII/XI pathway and glycoprotein VI controls collagen-induced thrombus formation under conditions of flow and coagulation. Proc. 9th UK - 1st Netherlands Platelet Meeting, London, UK 2007.

- Cosemans JMEM, Van der Meijden PEJ, Cleutjens JPM, Heeneman S and Heemskerk JWM. Platelet-derived matrix metalloproteinases have a dual role in occlusive thrombus growth under flow. Proc. 9th UK - 1st Netherlands Platelet Meeting, London, UK 2007. 


\section{Awards}

- Travel award from the Netherlands Foundation for Thrombosis and Haemostasis to visit the XXth Congress ISTH, Sydney, Australia (April 2005).

- Young Investigator Award of the International Society on Thrombosis and Haemostasis, XXth Congress ISTH, Sydney, Australia (August 2005).

- PhD student of August 2008 of newsletter Vascular Medicine. 
Dankwoord 


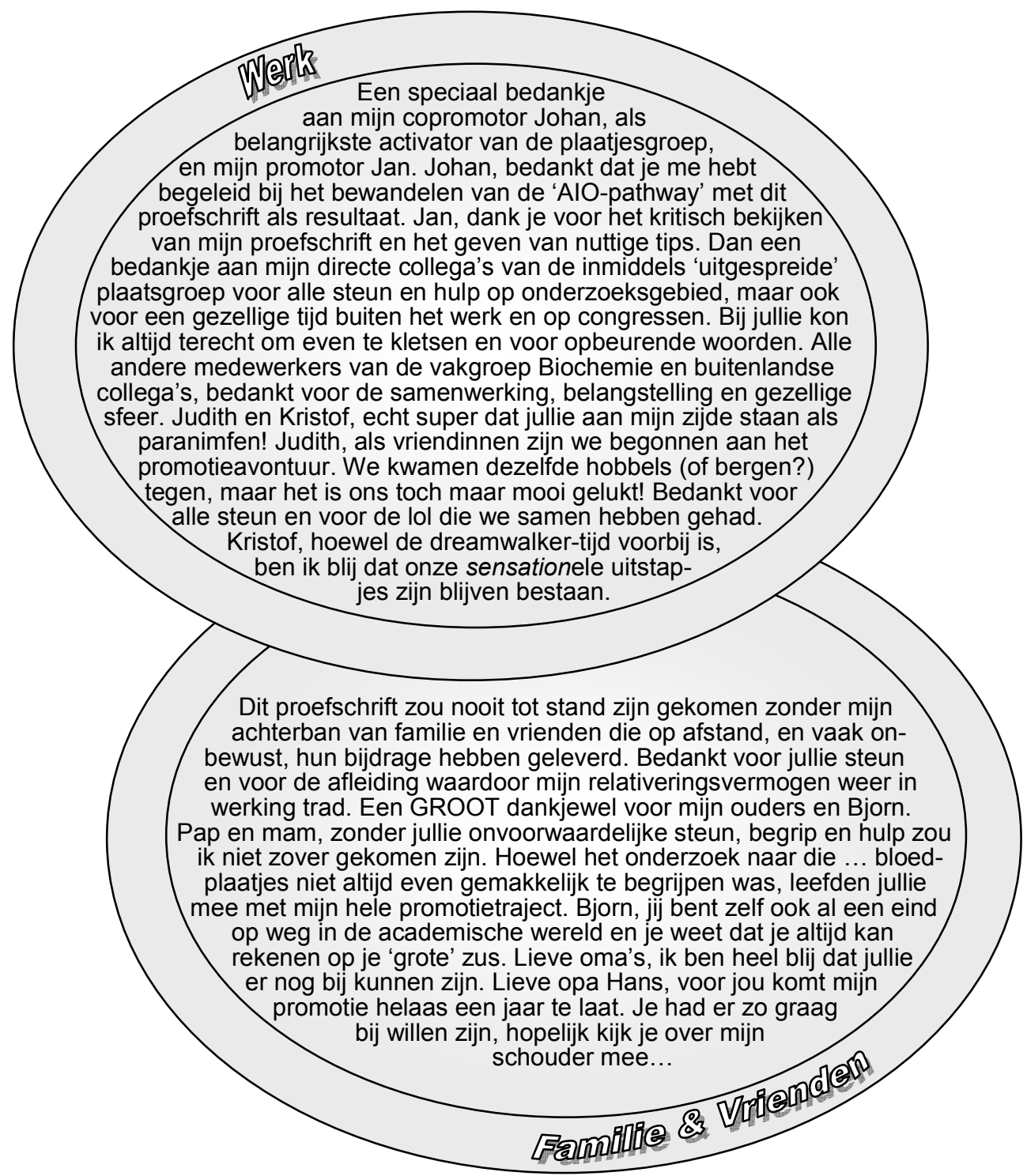




\section{Interactiemechanismen bij de totstandkoming van mijn proefschrift}

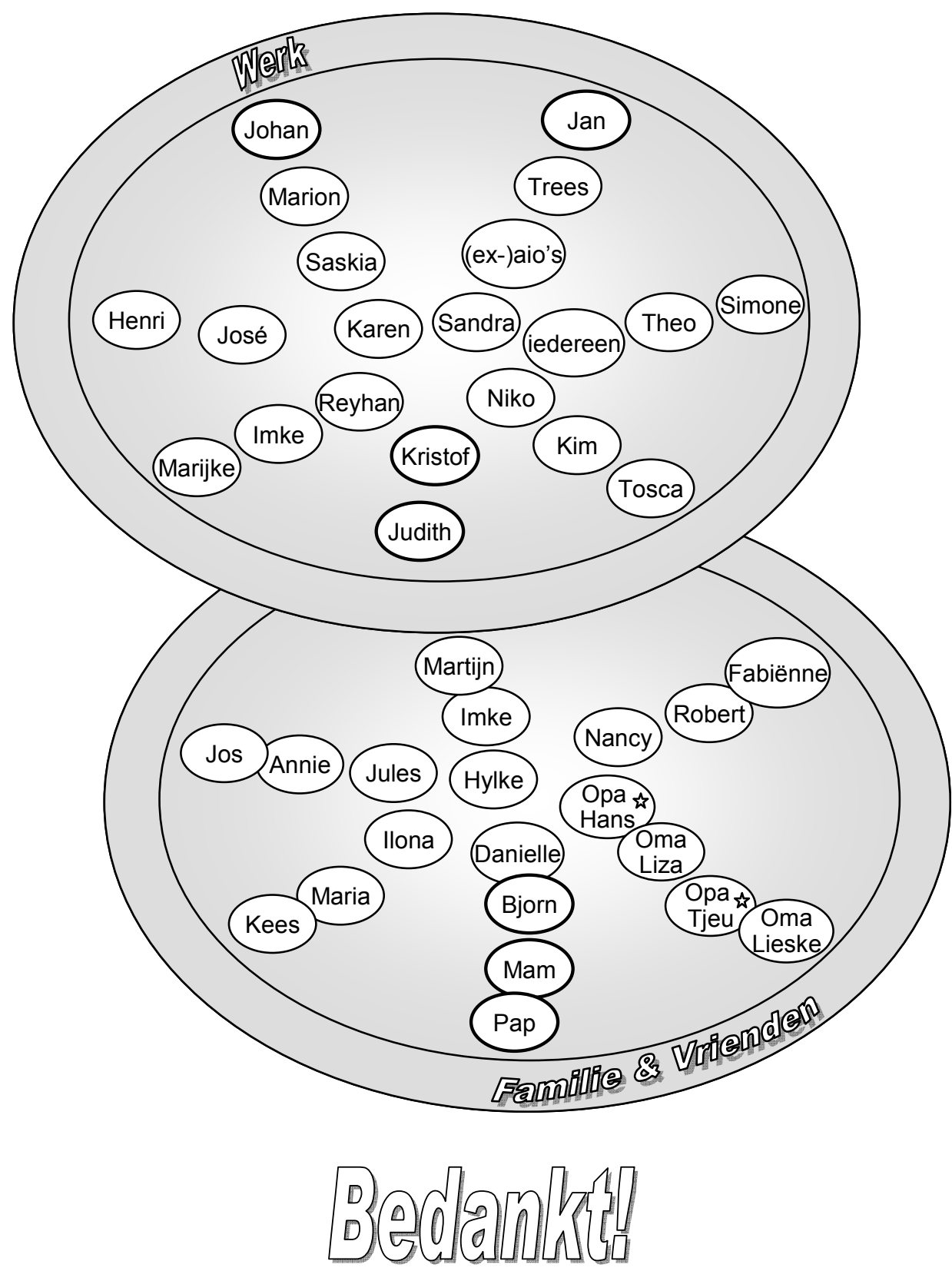

